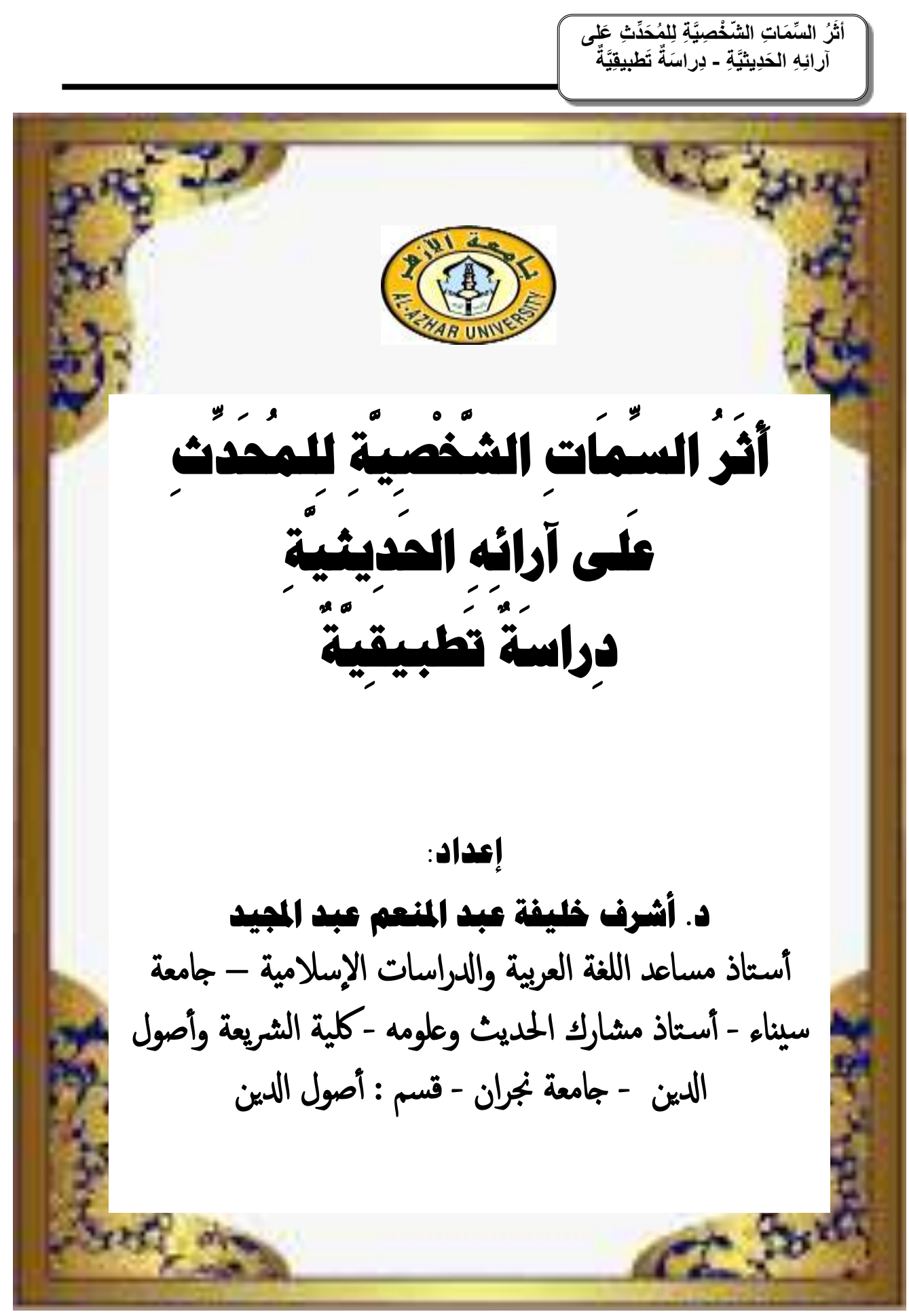

\title{
$7 r$
}

مجلة كلية اصول الاين والاعوة / العدد السابع و الثلاثتون 9 ـ ب م ـ الجزء الاول 
تؤثيثر مجموعة من المؤثرات على آراء العلماء بصفة عامة والمُحدِّثين خاصة، منها: السمات الثخصية؛ حيث يتناول البحث أثرها التطبيقي على آراء المحدِّث الحديثية من خلال منهج استقرائي تحليلي نقدي؛ فتبع البحث تعريف السمات الثخصية عند علماء النفس والمُحدِّثَين، وقرر البحث مَاخِلَ تطبيق هذه السمات الثخصية على المُحدِّثين، مع معالجة عدم تركيز كتب

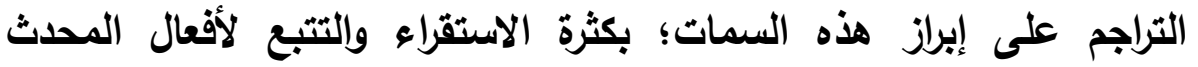
المترجم له، ونسبة كل فعل لما يخصه من الثخصية، وحدد خمسة أنواع التهاع

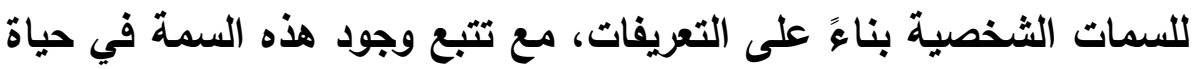
المُحدِّثين عامة؛ لتصنف كسمة حياتية أثرت في مجمل حياته وتعاملاته وآرائه العلمية؛ وهذه الأنواع الخمسة هي: الثخصية العصابية، ويمثلها قتادة

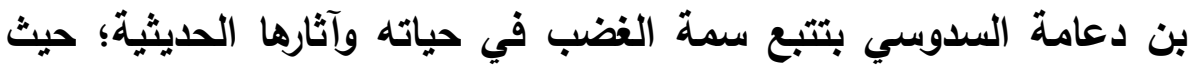

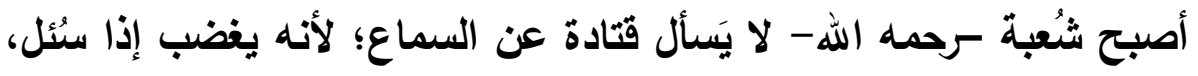
والثخصية الانبساطية، ويمثلها الواقدي من خلال تتبع سمة الاستثارة والإغراب وأثرها الحديثي، ثم الثخصية المقبولية وسماتها، ويظهر تطبيقها فئها

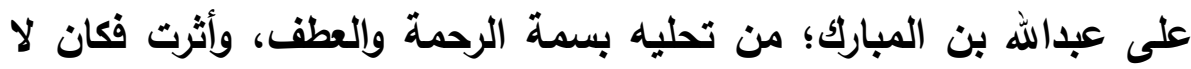

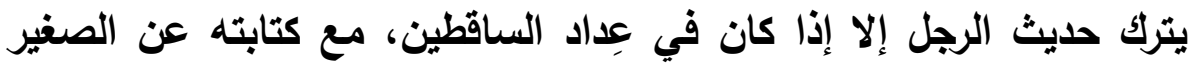

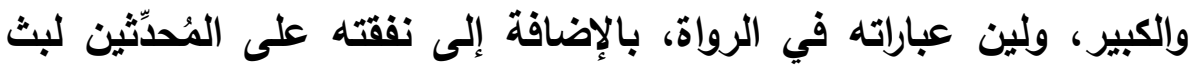

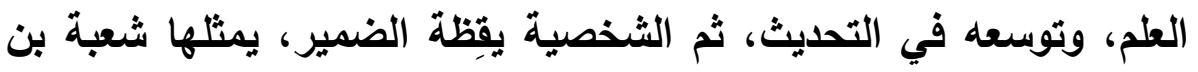

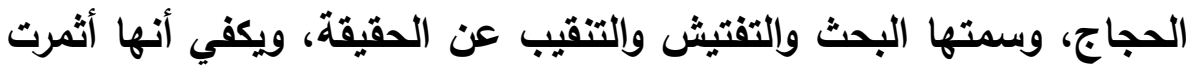
تأسيس علم الرجال، مع توثيق من وثَُّّه شعبة، ومقارنة الحفاظ مروياتهم 
بمرويات شعبة كقتادة وغيره؛ والثخصية الخامسة هي المنظقة على الخبرة، وسمتها الإصرار على الخطأ. وعرض البحث تطبيقًا من خلال حياة علي بن عاصم، ثم عرض البحث لمبحث سادس تتبع فيه سمة التثدد والتعنت كمبحث مستقل، وتطبيقاته، وييان أثره على آراء يحيى بن سعيد القطان، وترتب على ذلك عدم قبول تجريحِه لجماعة كممد بن إسحاق وعكرمة بن عمار، وتضعيفِه أحاديثَ صحيحة، وعلى الرغم من ظهور آثار السمات الشخصية للمُحدِّث على آرائه الحديثية، فِإن البحث أثبت موضوعية قواعد الحديث وعلومهة؛ حيث بقيث هذه القواعد ضابطة لعلم الحديث، لا تكسرها السمات الشخصية أو غيرها من العوامل؛ فسبحان مَن حفظ سنة نبيه بعبادٍ استعملهم في نصرتها.

\section{称郘称称㽞}




\section{ABSTRACT}

A number of influences affect the views of Muslim scholars in general and narrators of hadiths (Prophetic Sayings) in particular, including their personal characteristics. The research deals with the practical impact of such influences on the views of narrators with regard to hadiths (Prophetic Sayings) employing the inductive, analytical and critical methodology. The researcher traces the definitions of personal characteristics by psychologists and narrators of the hadiths (Prophetic Sayings).

The research has determined the ways to apply these personal characteristics to the narrators of hadiths (Prophetic Sayings) with the treatment of biography books which did not focus on making prominent these characteristics through frequently inducing and tracing the narrator's actions, and attributing each action to its characteristic. The research has identified five types of personal characteristics based on the definitions, and traced the existence of such characteristics in the lives 
of narrators in general in order to be classified as worldly life characteristics that have already affected their lives, dealings and scientific views.

These five types of personal characteristics are: Neurotic Character, represented by Qatada bin Saddam al-Sadousi and the characteristic of anger in his life is traced with its effects on hadiths (Prophetic Sayings) and Sho'ba- may Allah bless his soul- started to stop asking Qatada about hearing because the latter would get angry whenever he was asked about it, Extravert character, represented by $\mathrm{Al}-$ Waqidi by tracing the characteristic of excitation and exaggeration and its impact on hadiths (Prophetic Sayings), Acceptable Character and its features, represented by Abdullah bin Al-Mubarak for his being merciful and sympathetic. This characteristic had an impact since he would not quit the talk of any man unless he died, together with his writings about the young and the old, his sweet words in narrating, in addition to paying for the narrators of hadiths (Prophetic Sayings) to spread the science and expand in narrating hadiths. There is also 
the Character of Consciousness, represented by Sho'ba bin Al-Hajjaj, which searches for and explores the truth. It resulted in establishing Biographical evaluation with the documentation of what Sho'ba had already documented and comparing the narrations of the narrators like Qatada and others with Sho'ba's narrations. The fifth character is the character limited to experience, which insists on the error. The research shows an applied example through the life of Ali bin Assem. After that the research introduces a sixth part where it followed the feature of inflexibility and intransigence as independent research, and its applications in addition to its effect on the views of Yahya bin Sa'eed Al-Qattan and this resulted in the non-acceptance of the offense committed against a group like that of Mohammed bin Ishaq and Ekrema bin Ammar, and his weakening some true hadiths (Prophetic Sayings). Despite the emergence of the effects of personal characteristics of the narrator on his views in hadiths (Prophetic Sayings), the research has proved the objectivity of the rules of hadith 
(Prophetic Saying) and its science, where these rules remained in control of hadith science, not broken by personal characteristics or other factors. Glory be to Allah Who has kept safe His Prophet's Sunnah (Prophetic Traditions) through servants whom He used to send His victory upon that Sunnah.

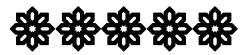




\section{|إلمدمة}

إن الحمد لله، نحمده، ونستعينه، ونستغفره، ونعوذ بالله من شرور أنفسنا ومن سيئات أعمالنا، مَن يهده الله فلا مضل لله، ومَن بضلل فلا هادي لله، وأشهد أن لا إله إلا الله وحده لا شريك له، وأشهد أن محمدًا عبده ورسوله.

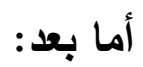

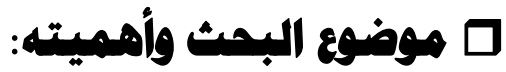

تؤثِّر مجموعة من العوامل على آراء العلماء عامة والمُحدِّثين بصفة خاصة؛ منها الأحوال السياسية والاجتماعية؛؛ حتى كان بعضهم يُصنّف الكتب للأمراء؛ فصنف الكرخي كتاب (تحليل النبيذ) لبعض الأمراء (')، وعن محمد بن موسى لاجي

(1) انظر: الاستقامة، تقي الدين أبو العباس أحمد بن عبد الحليم بن عبد السلام بن عبد

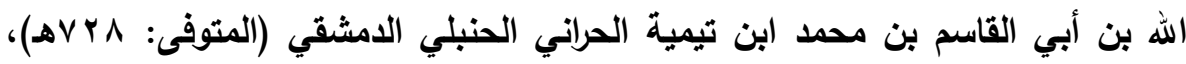

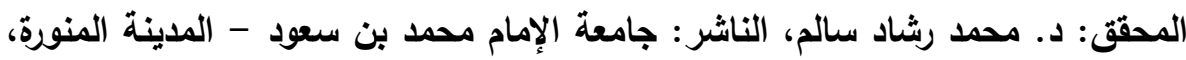

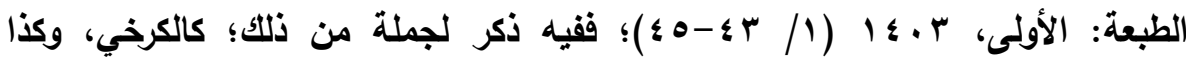
تصنيف ابن فورك كتابًا في مذهب ابن كلاب.

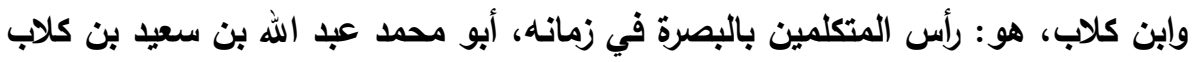

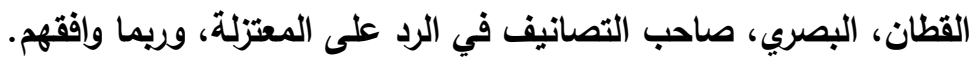
وكان يلقب: كلابا؛ لأنه كان يجر الخصم إلى نفسه ببيانه ويلاغته.

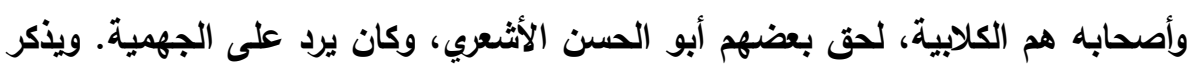

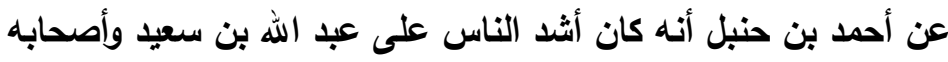

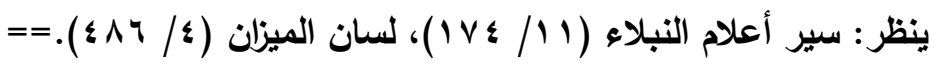


المأموني -صاحب النسائي- قال: "سمعت قومًا ينكرون على أبي عبد الرحمن النسائي كتاب (الخصائص) لعليٍٍ -رضي الله عنه-، وتركَه تصنيفَ فضائلِ الشَّيَخيْنِ، فذكرت له ذلك، فقال: دخلت دمشث والمنحرفُ بها عن عليّ كثيرٌ (')، فصنفت كتاب (الخصائص)؛ رجوت أن يهديهم الله تعالى"()،

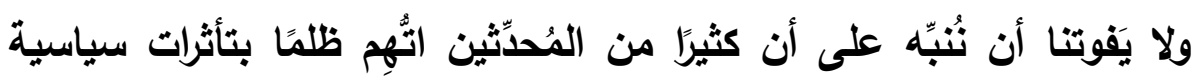
معينة، والواقع يشهر بخلافها (َ).

=="وينظر في شرح قول عبد الله بن كلاب في الاسماء والصفات في مقالات الإسلاميين

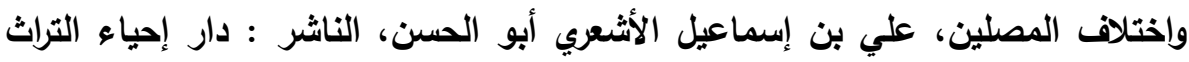

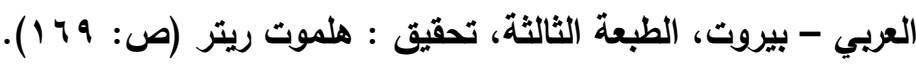
(1) لأن الشام كانت تدين لبني أمية.

(Y) سير أعلام النبلاء، شمس الدين أبو عبد الله محمد بن أحمد بن عثمان بن قَائماز

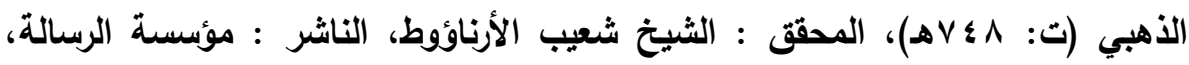

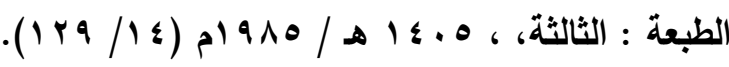

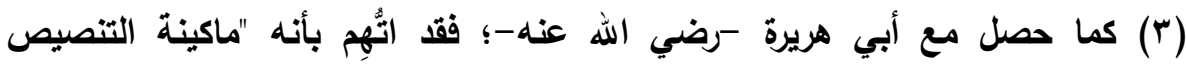

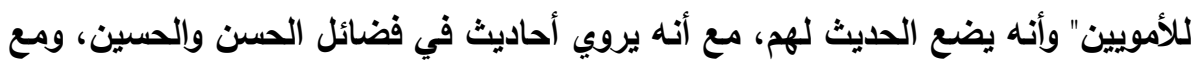
ثبوت إنكاره بعض المنكرات على الأمويين، بل الصحابة اختلفوا، وإقتتلوا ولم يُكنب بعضئه يُهن

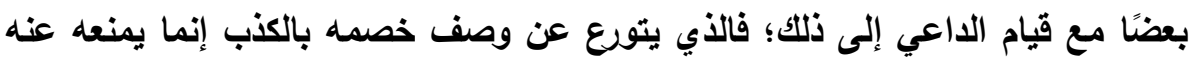

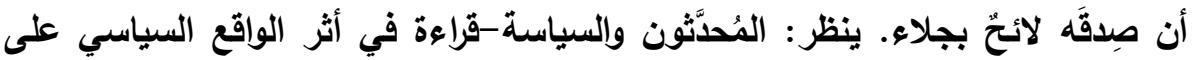

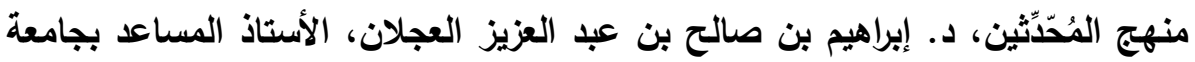

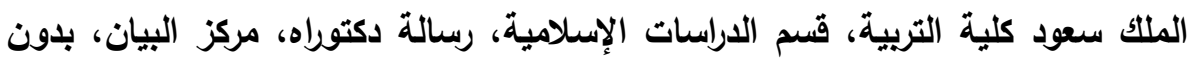

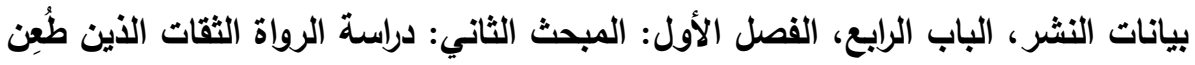

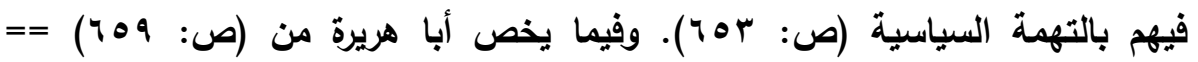
V. مجلة كلية اصول الاين والدعوة / العدد السابع والثلاثون 9 ـ ب م ـ الجزء الاول 
ومن المؤثرات الواضحة على الآراء العلمية والتوجهات الفكرية - أيضًا-

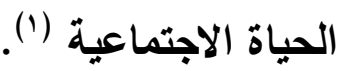

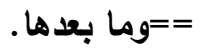

ومما تجدر الإثشارة إليه أن بعض هذه الاتهامات قد يكون لها أصل في عبارات الأقدمين

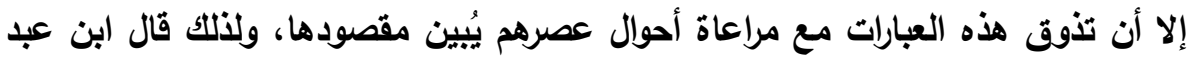

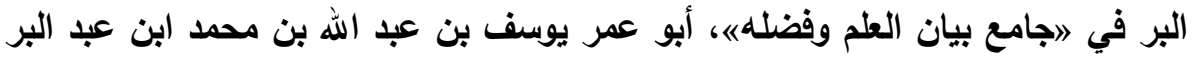

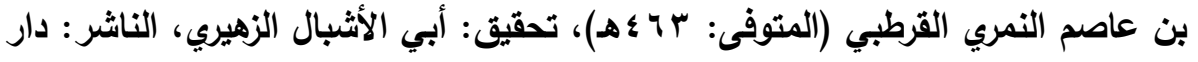

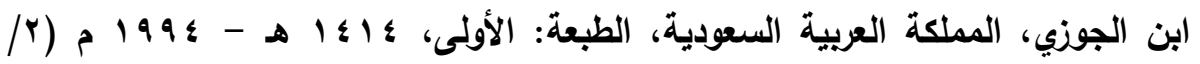

$:(1) \cdot 9$

اوقد كان أهل العرلق يصفون أهل المدينة أن العمل عندهم بأمر الأمراء مثل هشام بن

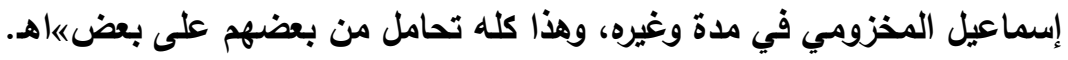

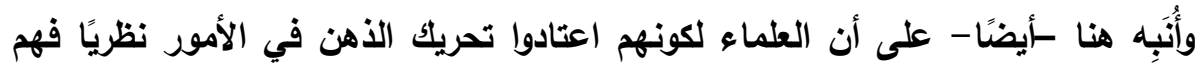

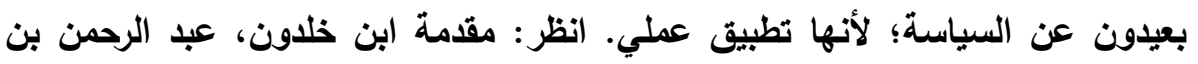

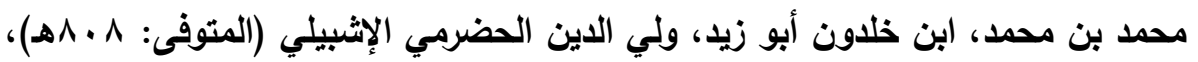

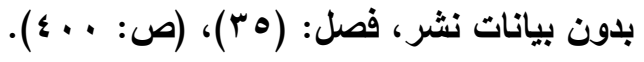

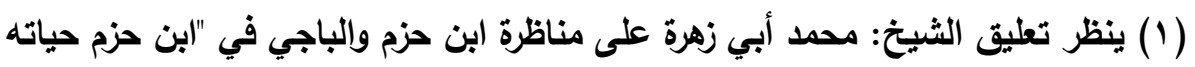

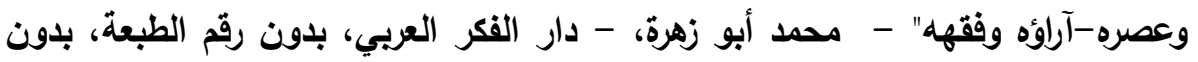

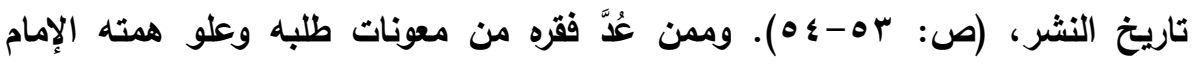
الثافعي. انظر : الثافعي حياته وعصره- آراؤه الفقهية، الإمام محمد أبو زهرة، ملتزم

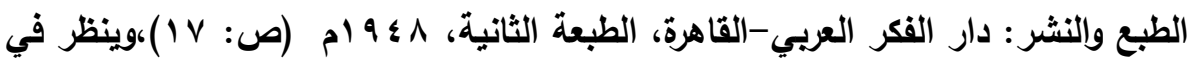

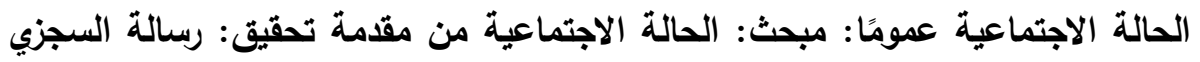
إلى أهل زبيد في الرد على من أنكر الحرف والصوت، عبيا الله بن سعيد بن حاتم == الله 
وتؤثر - أيضًا - السمات الشخصية على قرارات البشر بالإضافة إلى علىهم وآرائهم العلمية؛ فالشخص عصبيُّ المزاج تختلف قراراته عن الهادئ، وفهم هذه الطباع يُعين على تصوُّر مواقف الناس تصورًا صحيحًا، ولذلك خصنَّ بعض الفقهاء من كان شديا الغضب بأحكام تخصه في الطلاق والظهار ونحو ذلك(1)، مع أن الغضب صفة معتادة، وكذلك راعوا في الإفتاء سماتِ الشخص؛ قال الزركشي: "والأَّْلى أن مَن بُّلي بوسواس أو شُكٍّ أو قنوط، فالأولى أخذه بالأخف والإباحة والرخص؛ لئلا يزداد ما به ويخرج عن الشرع،

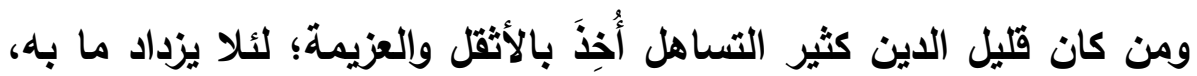
فيخرج إلى الإباحة"(؟)، وهذه السمات لها تأثيرٌ في تصرفات أصحابها

==السجزيّ الوائلي البكري، أبو نصر (المتوفى: ؟ ؛ ؛ هـ)، المحقق: محمد با كريم با عبد

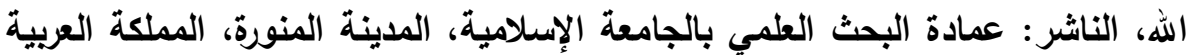

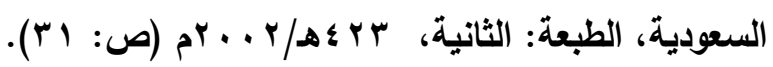

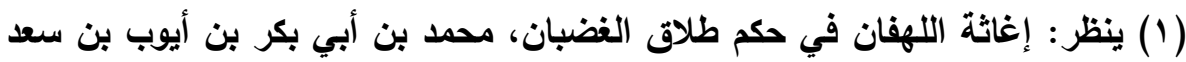
شمس الدين ابن قيم الجوزية (المتوفى: إهـهـ)، المحقق: محمد عفيفي، الناشر: المكتب الإسلاهي، بيروت، لبنان، مكتبة فرقد الخاني، الرياض، المملكة العربية السعودية المئه

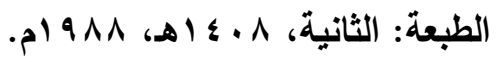
(Y) البحر المحيط في أصول الفقه، أبو عبد الله بلر الدين محمد بن عبد الله بن بهادر

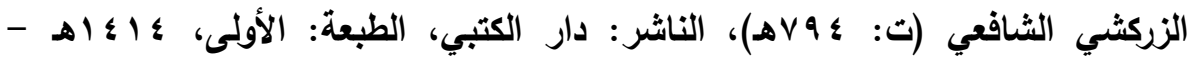

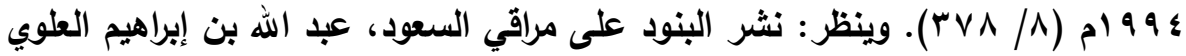

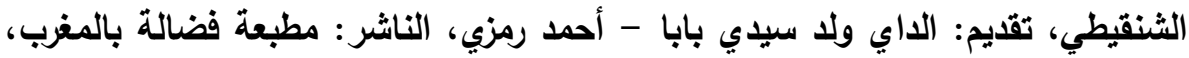

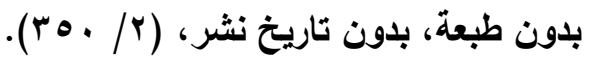


وتعاملهم؛ فسمات الأنبياء تختلف، ويبَيِن ذلك في تعاملهم مع أقوامهم، وسمات الصحابة تختلف، وق نبَّه النبي الصحابة بتفاوت سمات الأنبياء؛ فعن ابن مسعود قال: "لما كان يوم بلر،

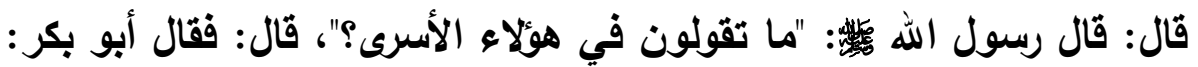
يا رسول الله، قومك وأهلك، استبقهم، واستأن بهم (1)؛ لعل الله أن يتوب هول عليهم، قال: وقال عمر: يا رسول الله، أخرجوك وكذبوك، قربهم فاضرب أعناقهم، قال: وقال عبد الله بن رواحة: يا رسول الله، انظر واديا كثير الحطب، فأدخلهم فيه، ثم أضرم عليهم نارا قال: فقال العباس: قطعت رحمك، قال: فخل رسول الله أبي بكر، وقال ناس: يأخذ بقول عمر، وقال ناس: يأخذ بقول عبد الله بن رواحة، قال: فخرج عليهم رسول الله كئ山س، فقال: "إن الله ليلين قلوب رجال فيه، حتى تكون ألين من اللبن، وإن الله ليشد قلوب رجال فيه، حتى تكون أشد من الحجارة، وإن مثلك يا أبا بكر كمثل إبراهيم - عليه السلام - قال:

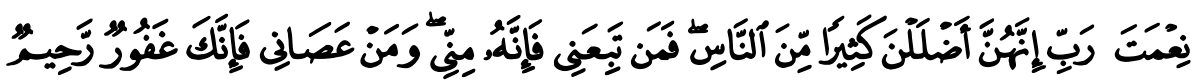

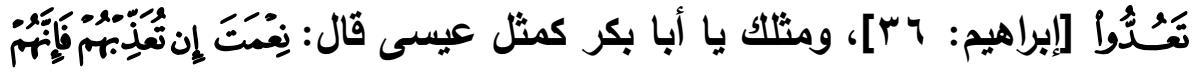

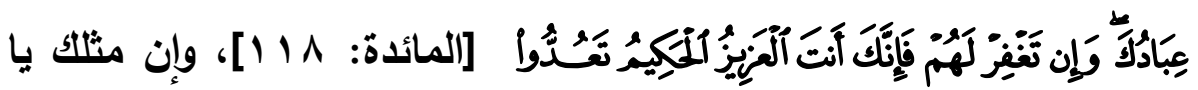

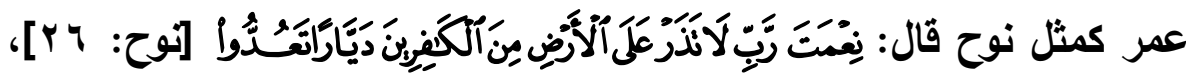

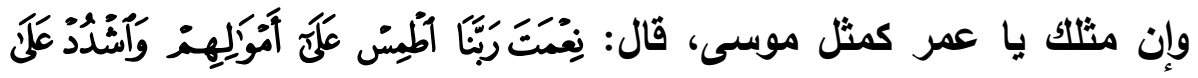




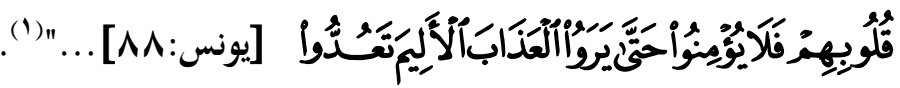

وهذه السمات لا تقدح فيمن وجدت فيه؛ فتبَيٌٌ الله موسى -عليه السلام كنموذج للشدَّة والغضب والعصبية -إن صح التعبير - لم يقدح ذلك في نبوته ولا مكانته - عليه السلام -، وكذلك أبو بكر وعمر -رضي الله عنهما-؛

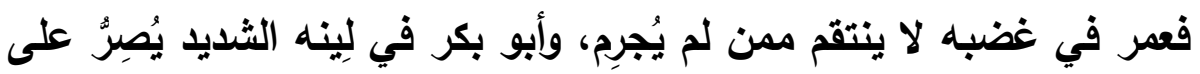

(1) أخرجه الإمام أحمد في مسند أحمد، أبو عبد الله أحمد بن محمد بن حنبل بن هلال

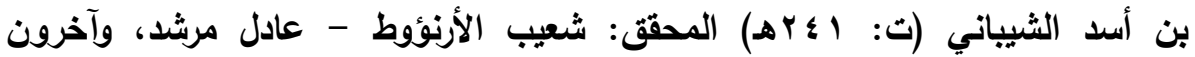

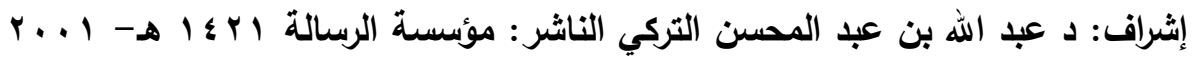

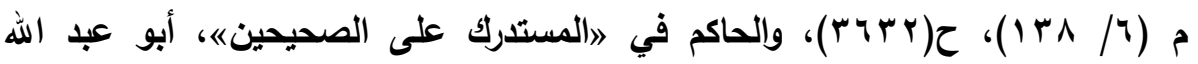
الحاكم محمد بن عبد الله بن محمد بن حمدويه بن نُعيم بن الحكم الضبي الطهماني

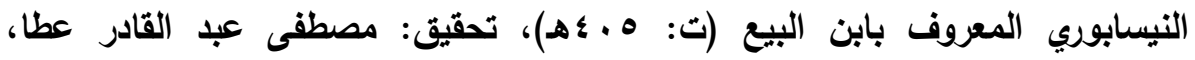

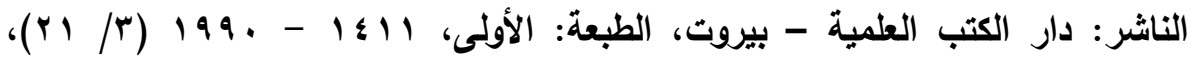

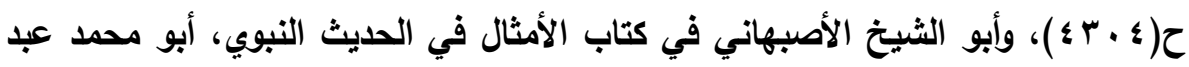
الله بن محمد بن جعفر بن حيان الأنصاري المعروف بأبِي الثيخ الأصبهاني (المتوفى الثي:

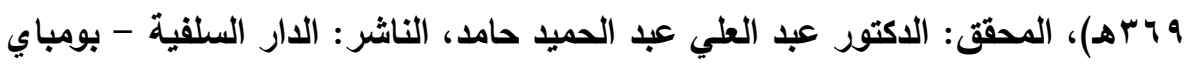

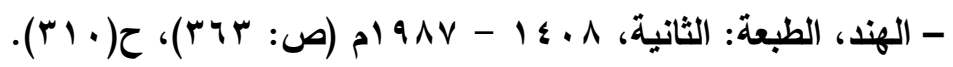

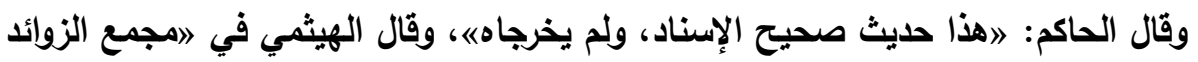
ومنبع الفوائده، المؤلف: أبو الحسن نور الدين علي بن أبي بكر بن سليمان الهيثمي

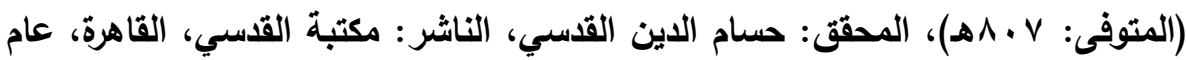

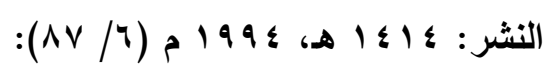
اورواه أبو يعلى بنحوه، ورواه الطبراني أيضا، وفيه أبو عبيدة ولم يسمع من أبيه، ولكن

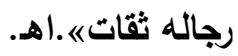


قتال المرتدين ومانعي الزكاة(')، ويكون أثد الناس في ذلك؛ فسِماته لم تطغ

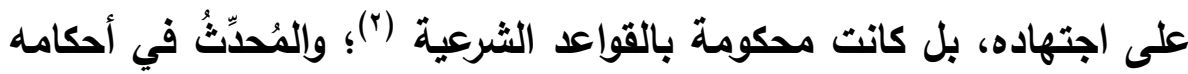
الحديثية عامة محكوم بقواعدَ علميةٍ؛ فيتناول هذا البحث تأثير هذه السمات

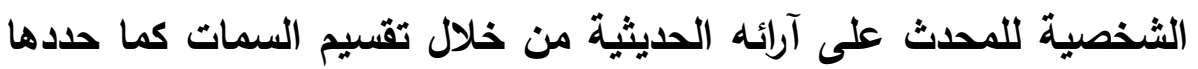

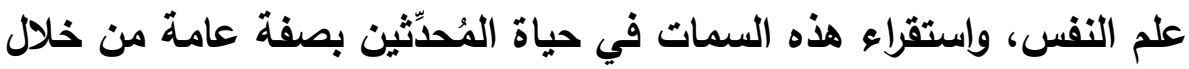

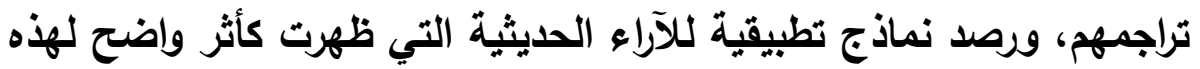

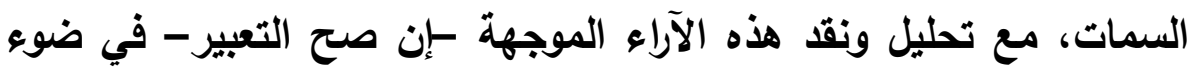
قواعد علم الحديث الموضوعية. وتظهر أهمية الموضوع في مناقثة العوامل المؤثرة على الآراء العلمية

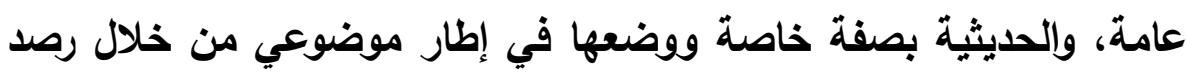

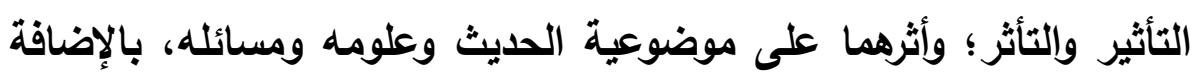

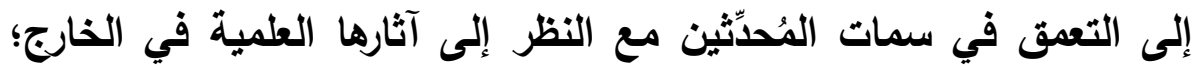

(1) القصة معروفة متداولة في الصحاح والسنن وكتب السير بما يُنتي عن استقصاء مصادرها.

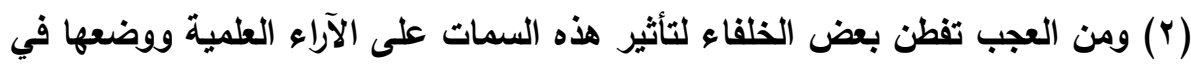

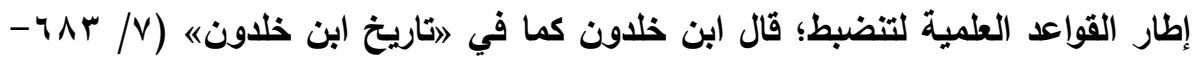

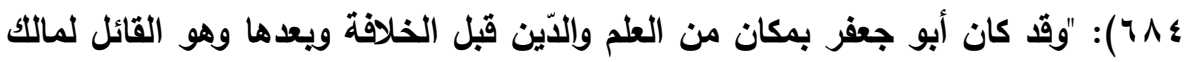

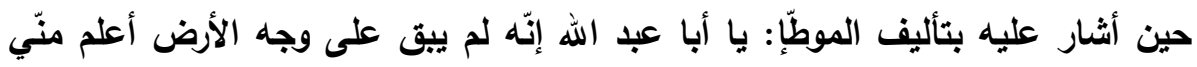

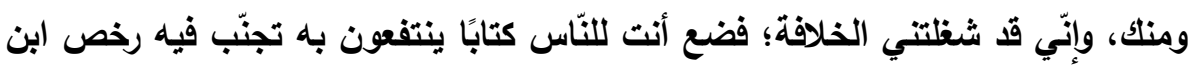

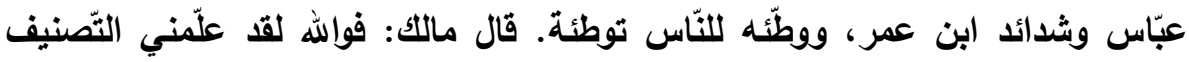

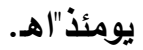


فمن المُستلَّم أن لكل محدٍِّ صفاتٍ تُميزه عن غيره سواء أكاتت هِبِيَّة أم

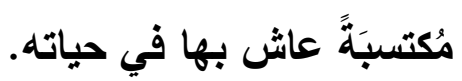

من خلالها آثار هذه السمات على آراء المُحدِّين فهل استطاعت هذه القواعد

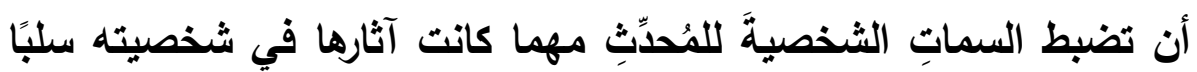

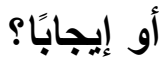

ولو فرضنا أن القواعد لم تضبط ذلك في روايات المُحدِّث وجرحه وتعديله للرواة، فهل تتبه علماء الجرح والتعديل لهذا، وضبطوه بقواعد حاكمة؟! هذا ما نتناوله في هذا البحث، وهو تأثير هذه السمات في الآراء الحديثية، وكيف يتفاعل الجانب النفسي مع الجوانب العلمية دون الإخلال بقواعد

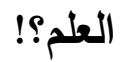
وتتضح أهمية البحث من التعمث في سمات المُحدِّثين مع النظر إلى آثارها

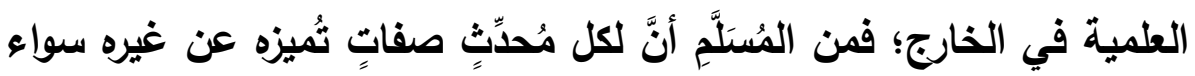

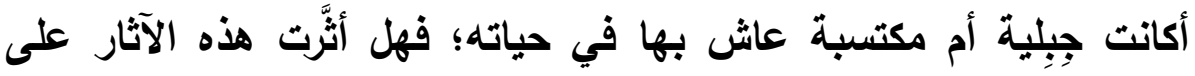

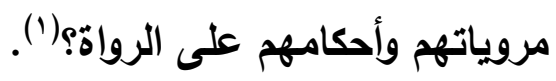
ه أسباب اختيار الموضوع: يتضح من خلال الطرح : أن السبب الرئيسَ لاختيار الموضوع هو كثرة (1) ومرادنا بالسمات هنا ما يُعرف بالأنماط الثخصية، ويأتي التعريف بها في أول

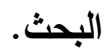

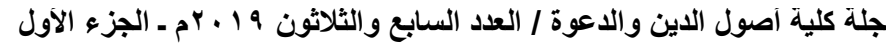


المؤثثرات الواضحة على آراء المُحدِّثني؛ مما يؤثثر على توجيه الرأي الحديثي،

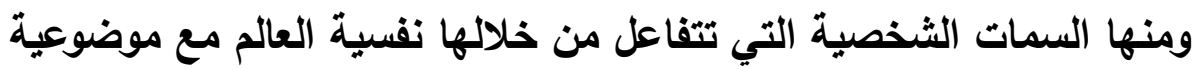
العلم وقواعده؛ لذا يظل إزالة اللبس والتضاد الظاهري بين تأثير السمات

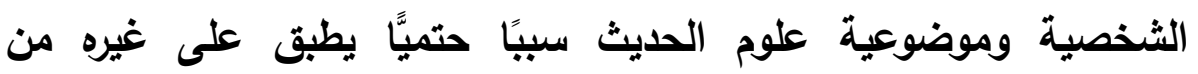

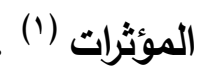

\section{ه أهداف البمث:}

يهاف البحث إلى مجموعة من الأهداف، كما يلي:

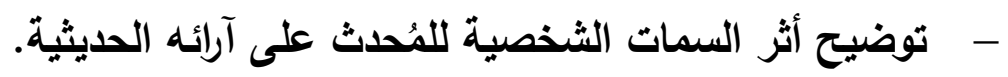

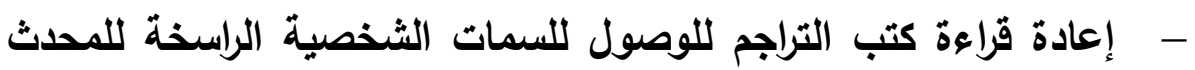
قبل اشتغاله بالحديث. - - المقارنة بين أثر السمات الثخصية للمُحدّث قبل اشتغاله بالتحديث

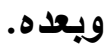

- بيانُ نماذج تطبيقَّةٍ لأثر السمات الثخصية على توجيهات المحدث

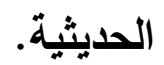

- بيان موضوعية علوم الحديث وعلمائها في مناقثة المسائل العلمية. ه تساولات الدراسة: كما تهدف الدارة إلى الإجابة عن عدة تساؤلات مهمة في هذا الجاتب:

(1) فهذا طرح بحثي لمناقثة التداخل المعرفي بين الحليث وعلومه والعلوم الأخرى وفتح

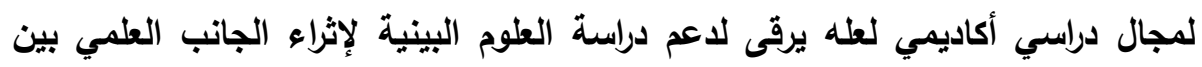

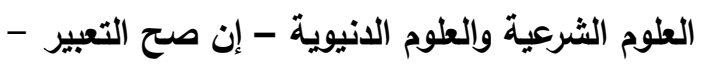

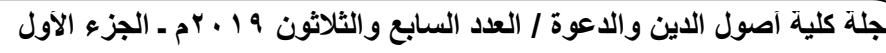


- ما تعريف السمات الشخصية بين علماء النفس والمُحدِّثنْ؟ - - ما التأثيرات التطبيقية للسمات الثخصية للمحدث على آرائه الحديثية؟ - هل كاتت السمات الشخصية المؤثرة على آراء المحدث التطبيقية موجودةً في حياته قبل الاثتنغال بالعلم؟ - هل استطاعت القواعد الحديثية أن تضبط الآراء الحديثية بعيدًا عن فودئ العوامل المؤثرة على هذه الآراء؟ - - هل تغيرت سمات المُحدِّثين بعد اشتغالهم بالتحديث أم هو أثز من آثنار

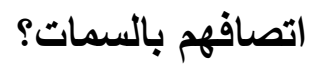

- - كيف يتفاعل الجانب النفسي مع الجوانب العلمية دون الإخلال بقواعد

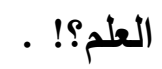

口 الإنهمج والإجماكات :

اعتمدت الدراسة على عدة مناهج هي: الاستقرائي(')، المنهج التحليلي(؟)،

(1) المنهج الاستقرائي أو التجريبي، هو: القائم على الملاحظة والتجربة."انظر مناهج البحث العلمي، عبد الرحمن بدوي، الناشر: وكالة المطبوعات بالكويت، الطبعة الثالثة،

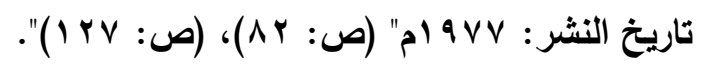

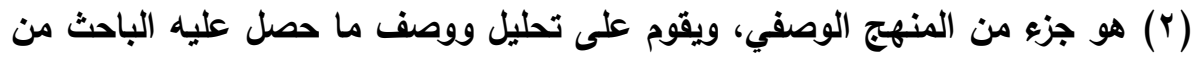

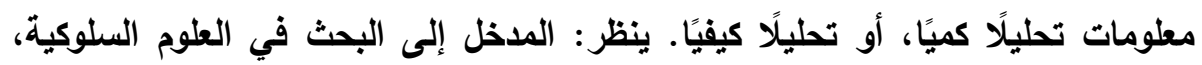

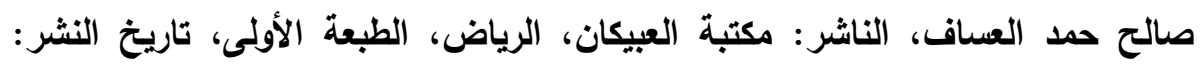

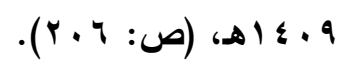

\section{V^}

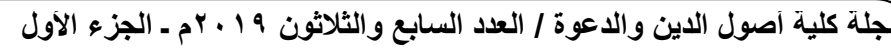


وإلنقدي(') مع استخدام المقارنة من خلال الخطوات الآتية: - الوقوف على تعريف السمات الثخصية بين علماء النفس وعلماء الحديث.

- - التعريف بالعوامل الخمس الكبرى للشخصية من خلال الدراسات النفسية. - عمل مدخل لمدى إمكان تطبيق نظرية العوامل الخمس على المُحدِّثين وآرائهم الحديثية.

- - - تقسيم المباحث بحسب أنواع الثخصيات الخمسة. - - حصر جملة من السمات الثخصية، وتطبيقها على نماذج من المُحدِّثَين

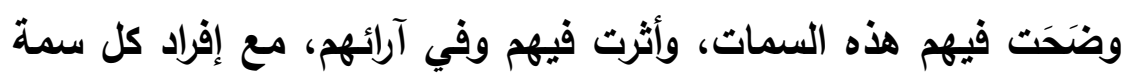
بمبحث خاص بها. - - مَمْعُ أقوالِ وأفعال المُحدِّثَين التي يمكن أن تلخل في السمات الثخصية

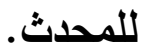

- - المقارنة بين سمات شخصية المحدث قبل اثتغاله بالتحديث ويعده. - -

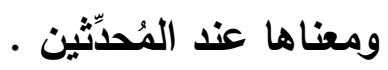

(1) يعتمد المنهج النقاي إلى حد كبير على التلليل المنطقي للوصول إلى حلول ونتائج

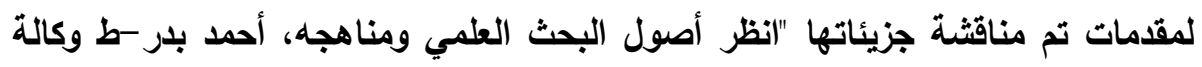

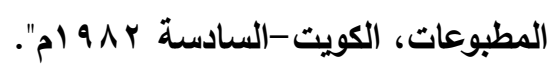

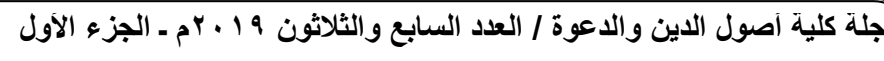




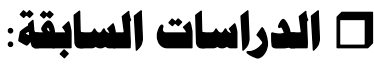

لا أعلُُ -في حدودِ بحثي - دراسةً أو بحثًا درس مسأكة السمات الثخصية

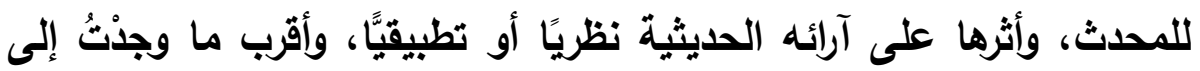

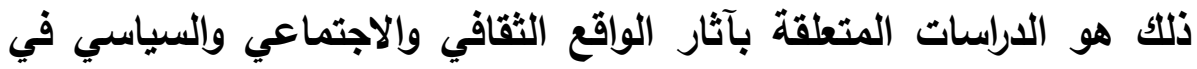

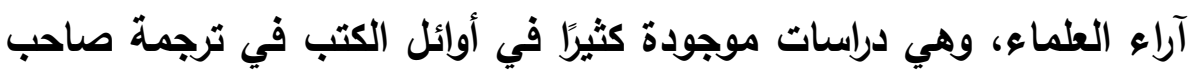

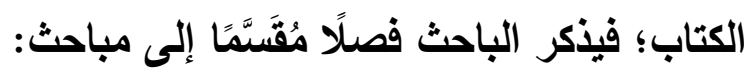
المبحث الأول: الحالة السياسية في عصر المؤلف. المبحث الثاني: الحالة الاجتماعية والاقتصادية فيه. المبحث الثالث: الحالة العلمية في هذا العصر (')، ونحو ذلك.

(1) ينظر على سبيل المثال: الاعتصام، إبراهيم بن موسى بن محمد اللخمي الغرناطي

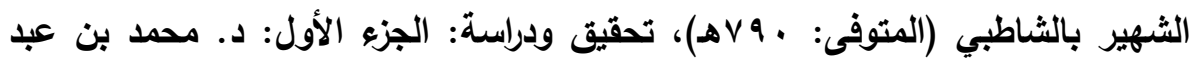

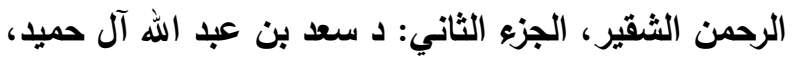

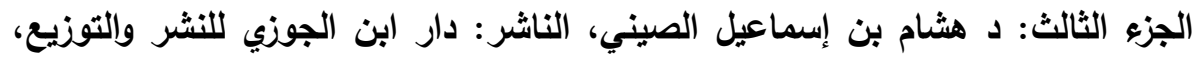

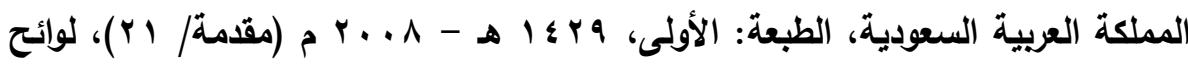
الأنوار السنية ولواقح الأفكار السنية الشرح قصيدة ابن أبي داود الحائية في عقيدة أهل

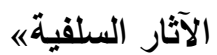
المؤلف: محمد بن أحمد بن سالم السفاريني الحنبلي، (المتوفى: 1111 هـ)، دراسة

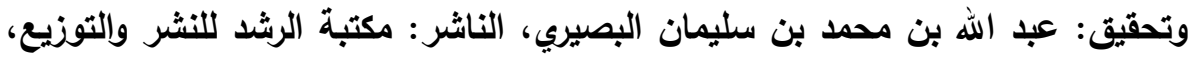

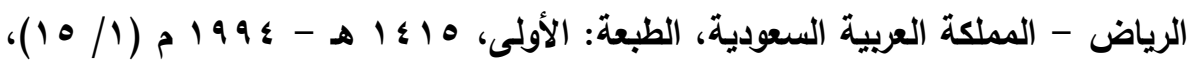

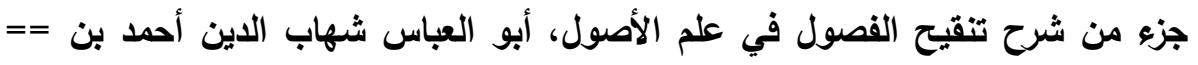
$\Lambda$. جلة كلية اصول الدين والدعوة / العدد السابع و الثلاثون 9 ا ـ بم ـ الجزء الاول 
ولكن عامة هذه المقدمات لا تعدو أن تكون مقدماتٍ شكليَّةً؛ لتجاوز

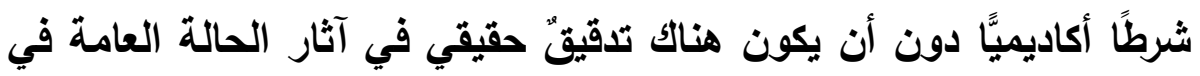

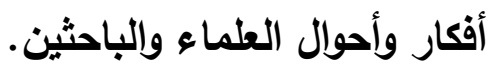
ومن المقالات المُفردة في ذلك:

- التكوين الثقافي والاجتماعي لقضاة البصرة في العصر العباسي

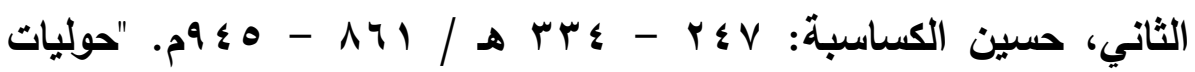

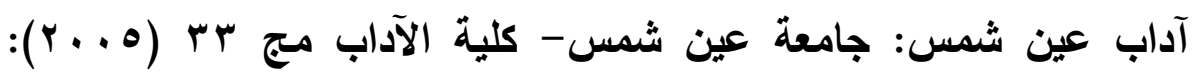

(') 197-198

=إدريس بن عبد الرحمن المالكي الثهير بالقرافي (المتوفى: ع^آهـ)، إعداد الطالب:

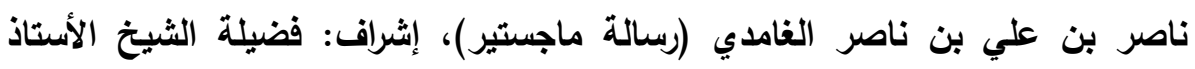

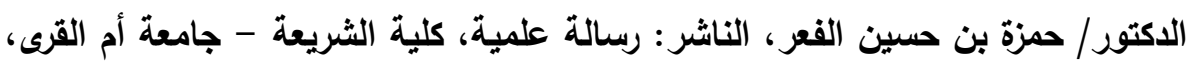

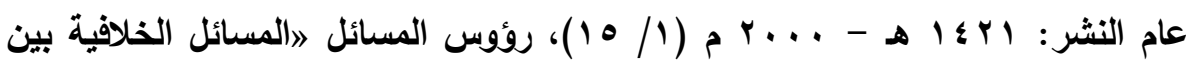

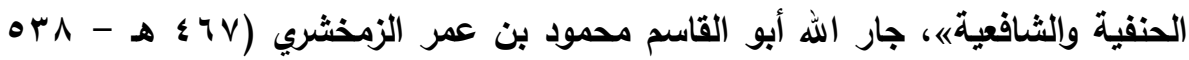

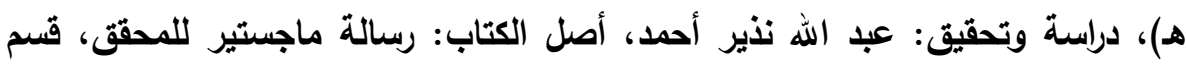

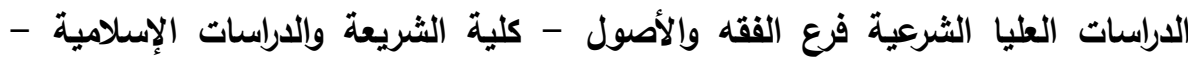

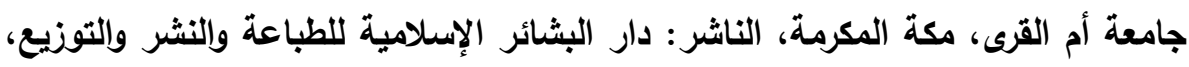

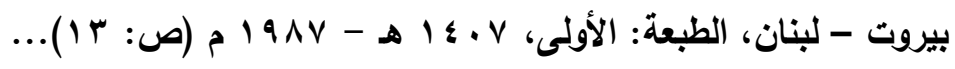

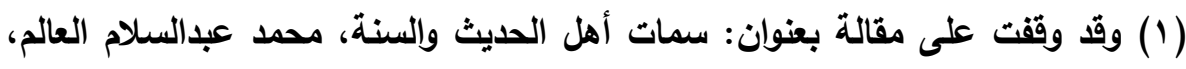

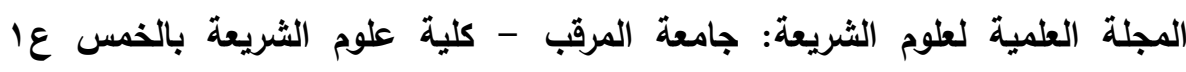
. T19-071: (r.11) إلا أنني بعد مطالعتها وجدتها بعيدة عن موضوعنا، فهو يتكلم على بعض ما يُمبيز ==

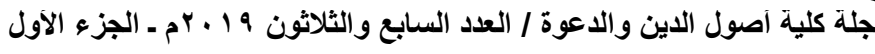


وهم في ذلك مدفوعون بما حكاه ابن خلاون - رحمه الله- عن الحكماء؛ إذ قال: "الاجتماع الإنساني ضروري، ويعبر الحكماء عن هذا بقولهم: الإنسان مدني بالطبع؛ أي: لا بد لله من الاجتماع الأي هو المدينة

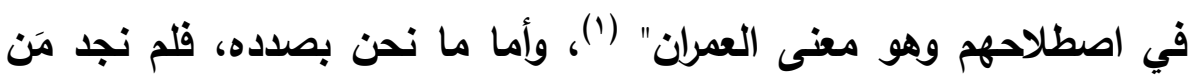
صوَّب النظر إليه دراسة وتحليلًا، وإلا فظهوره في أذهان علماء الحديث واضحٌ، كما سيحاول هذا البحث عرضه واستقرائه وتحليله سوالله الموفق - .

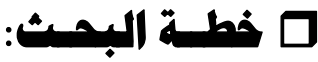

اقتضت طبيعة هذه الدارسة ومنهج البحث فيها تقسيمها إلى تمهيد تعريفي، ينقسم إلى ثُلاث نقاط، ثم ستة مباحث تتعلق بالسمات، يسبق ذلك المقدمة، ثم تمهيد، ويلي الاراسة الخاتمةُُ وأهم النتائج، ثم ذِكْرُ المصادر والمراجع التي داهي اعتمدث عليها الدراسة، ثم الفهارس، وتفصيلها كالتالي : المقدمة: وقد اشتملت على بيان أهمية الموضوع، وأسباب اختياره، وأهدافه،

=="جملة أهل الحديث عن غيرهم؛ كتمسكهم بالقرآن والسنة، ولا يتناول السمات الشخصية لمحدِّث بعينه. (1) مقدمة ابن خلدون (ص: · ب). وهكذا اشتهرت العبارة عنه، وإلا فهو ينقلها عن

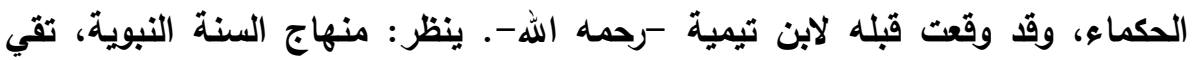

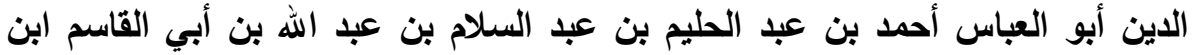

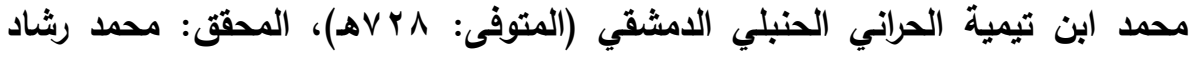

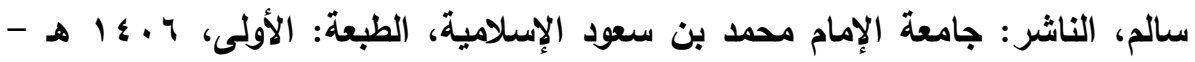

$$
\text { . (r99/7) ( } 1914
$$


ثم عرضُ عام لخطة الدراسة وذِْكْرُ الضوابط المنهجية، التي سار عليها

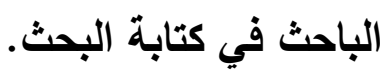
التمهيد وينقسم إلى:

أولاً: التعريف بالسمات الثخصية باعتبار المفردات وإلمركب، ويتبعه: ا ـ السمة عند علماء النفس: r. T. السمة عند علماء الحديث: ثانياً: التعريف بالعوامل الخمسة الكبرى للشخصية : وينتظم في ستة مباحث بحسب أنماط الثخصيات الثخصية الخمسة، ثم مناقثة سمة التعنت عند المُحدِّثين في مبحث خاص: المبمث الأول : آثار الثخصية العصابية على المُحدِث، (سمة (لغضب) أنمونجًا.

المبمث الثاني : آثار الثخصية الانبساطية على المُحدِّ، (سمة البحث عن الاستثارة أو الإغراب) أنموذجًا.

المبـث الثالث : آثار الثخصية المقبولية على المُحدِّ، (سمة الرحمة والعطف) أنموذجًا.

المبمث الرابع : آثار الثخصية يَقِظة الضمير على المُحدِّث ، (سمة البحث والتفتيش والتتقيب عن الحقيقة) أنموذجًا. $\Lambda r$

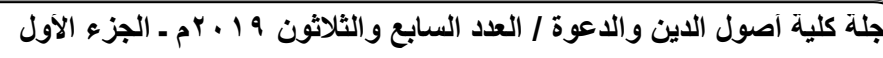


المبمث الخامس : آثار الثخصية المنظلقة على الخبرة على المُحدِّ، (الإصرار على الخطأ) أنموذجًا.

المبمث السادس: آثار سمة التعنت على المُحدِّين (') .

ثم الخاتمة ، أهم النتائج والتتوصيات، وفهرس لأهم المصادر والمراجع. $\sin \Delta \cos$

(1) ريما كان الأولى أن نترك البحث ينتظم في خمسة مباحث، لكن لكون هذه الصفة الكبا

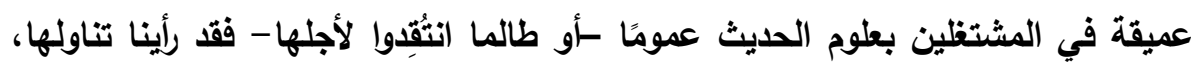
والتوسع في تحليلها.

جلة كلية اصول الاين والدعوة / العلد العابع والثلاثتون 9 ـ بام ـ الجزء الاول 


\section{|لتمبمدصد}

السمات الشخصية (تعريفها-أنواعها- آثارها، والعوامل الخمسة الكبرى للشخصية: مدى إمكان النظر في آثار هذه العوامل على المُحدِّثين ووضع قواعد ضابطة ومداخل للاراسة)

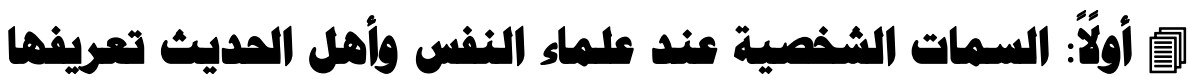

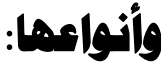

قبل التعرض إلى تعريف "السمات الشخصية" نشير إلى أن القرآن الكريم قد

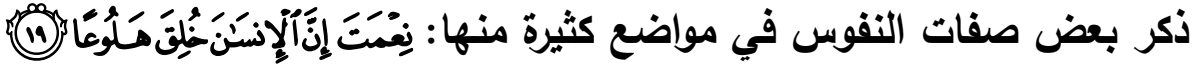

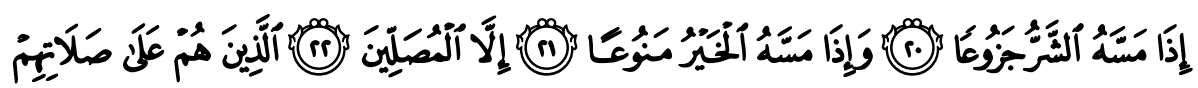

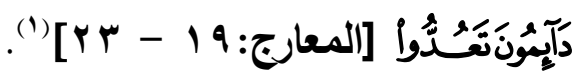

وهو وصفٌ دقيق في التعاطي المالي مع ذكر بعض ما بضبط هذه الصفة؛ كادامة الصلاة.

وقد جاء في الستُنَّة أحاديثُُ كثيرةُ يَضِيق المقام عن ذِكْرها(َ).

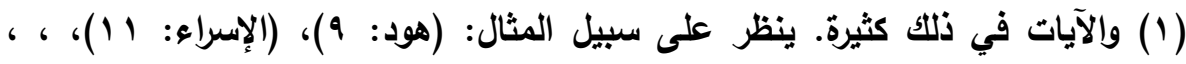

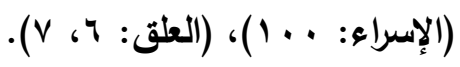

(Y) بوَّب العلماء على ذلك أبوابًا جمعت أحاديث. ينظر على سبيل المثال: الأدب المفرد،

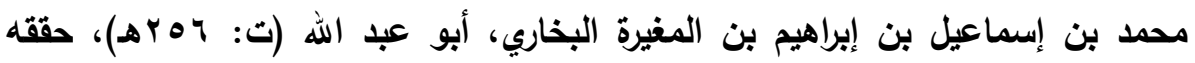

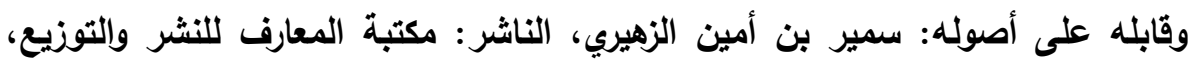

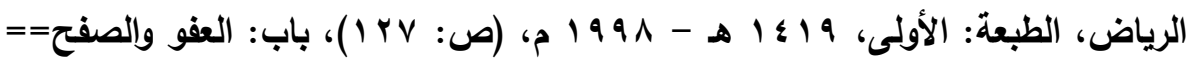


ثم ندلف إلى تعريف مصطلحات البحث.

ם التمريف باعتبار مفزديه:

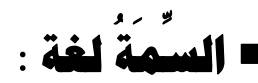

مصدر وَسَََ؛ وهي العلامة التي يميز بها الحيوان عن غيره. قال الزَّبيدي (ت بهي

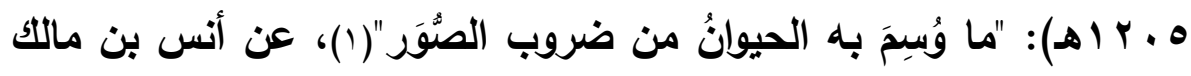

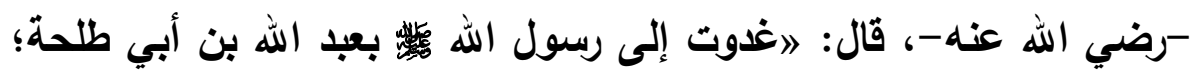
ليُحنِّهة، فوافيته في يده الميسم يسم إبل الصدقةه (َ).

ثم عمم العرب استخدامها، فأصبحت تطلق على كل علامة وسَمْتٍ يعرف بها.

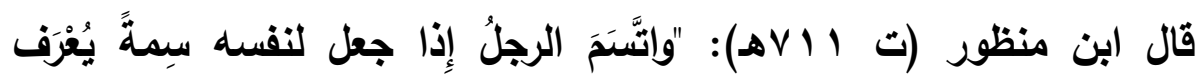

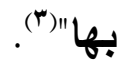

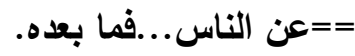

(1) تاج العروس من جواهر القاموس، محمّل بن محمّد بن عبد الرزّلق الحسيني، أبو

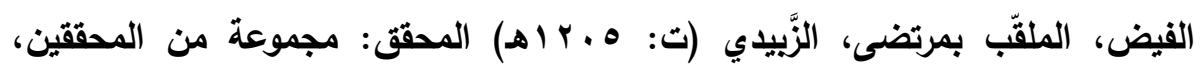

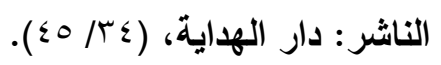

(Y) أخرجه البخاري في صحيحه 》الجامع المسند الصحيح المختصر من أمور رسول الله -صلى الله عليه وسلم- وسنته وأيامه" = 》صحيح البخاريه، محمد بن إسماعيل أبو

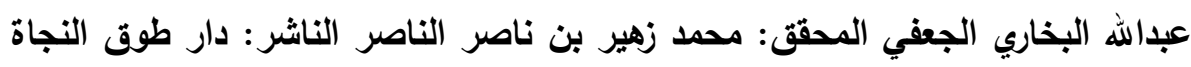

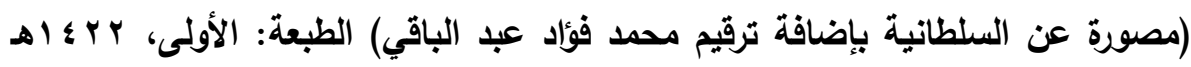

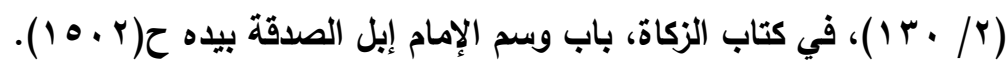

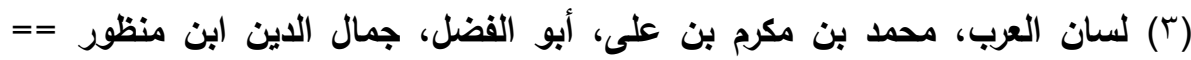
19 جلة كلية اصول الدين والدعوة / العدد السابع و الثلاثون 9 ا ب بم ـ الجزء الاول 


\section{:

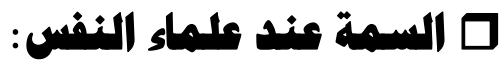

توبع علماء النفس في مباحث السمة وخصائصها ومعاييرها؛ وذلك لأن السمة متعلقة بوصف السلوك وتنظيمِه والتتبوِ بها، وذلك من أهم الأبواب

التي يتطرق إليها علم النفس ويتتاولها(1). السمة: إطار مرجعي، ومبدأ لتنظيم بعض جواتب السلوك والتتبّؤ به، وهي

مُستتتجة ممّا نلاحظه من عمومية السلوك البشري (؟). ويظهر من تعريف علماء النفس أنه أخص من التعريف اللغوي؛ فقد خصتوه من مطلق العلامة إلى علامة خاصة في السلوك البشري؛ والسمات ليست علةً للسلوك البشري، ولا نتيجة عنه، وإنما هي مفاهيم تساعدنا على وصف في في

السلوك البشري، والتتبؤ به(ז).

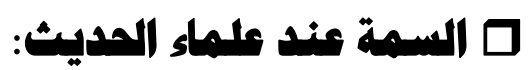

أما علماء الحديث، فلم يشتهر استخدام هذا اللفظ في مصنفاتهم، إلا ما قصد

==الأنصاري الرويفعى الإفريقى (ت: III Iه)، الناشر: دار صادر - بيروت، الطبعة:

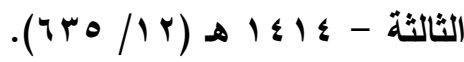

(1) ينظر: الأبعاد الأساسية للشخصية، دكتور : أحمد محمد عبد الخالق، تقديم: دكتور: هانز أيزتك: أستاذ علم النفس بجامعة لندن - دار المعرفة الجامعية، الإسكندرية: (الطبعة الإسية

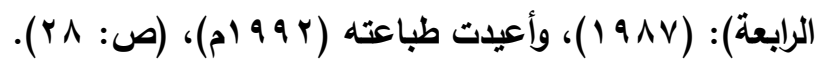

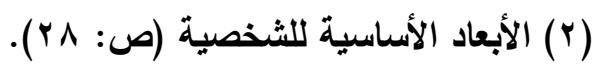

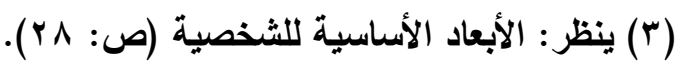


به المعنى اللغوي؛ أي: العلامة؛ ومن أمثلة ذلك ما قاله الإمام مسلم (ت التهام ا Y Y هـ): "السمة التي تعرف بها خطأ المخطئ في الحديث وصواب غيره إذا

أصاب فيه" (') - (1)

ولم نجد لأهل الحديث استعمال السمة بمعنَى خاص، ولا بمعناها عند علماء النفس.

\section{口 تمريف الشمهيدة:}

\section{| الشفمسية لغنة:}

قال الخليل بن أحمد (ت V Vه): "الثخص: سواد الإنسان إذا لأيته من بعيد، وكل شيء رأيت جسمانه فقد رأيت شخصه، وجمعه: الثخوص والأثخاص"(؟)، فالمراد به إثبات الأات دون النظر إلى صفات الشخص؛

(1) التمييز، مسلم بن الحجاج أبو الحسن القشيري النيسابوري (المتوفى: آYYه)، المحقى: د. محمد مصطقى الأعظمي، الناشر: مكتبة الكوثر - المربع - السعودية،

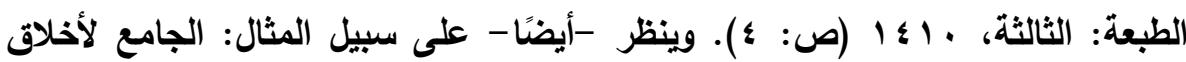

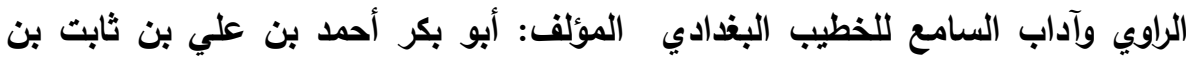

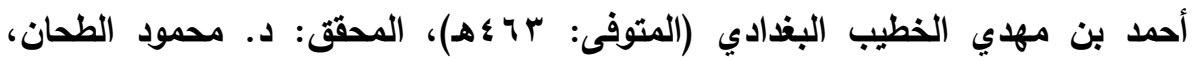

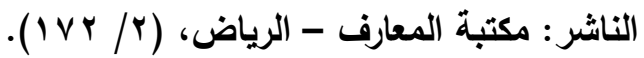

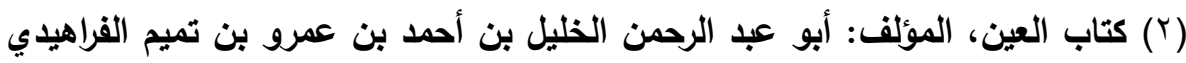
البصري (المتوفى: • V Vه)، المحقق: د الد مهذي المخزومي، د إبراهيم السامرائي، الناشر:

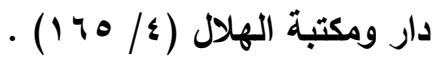


وهكا يسير مدلول الكلمة في المعاجم العربية دون زيادة في المعنى (1) ويظهر من ذلك أن كلام اللغويين ياور حول كون الشخص = "ذات الثيء".

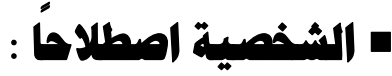

\section{口 الشفمسية عند علمار النفهى:}

على عكس ما ذهب إليه اللغويون فإن علماء النفس ذهبوا إلى تعريف الشخصية على أنها أمر مغايز للأات، بل كلامهم يدور على أوصاف الذات. وقد نَقلَ ذلك عنهم بعضُ علماء اللغة المعاصرين في تعريف الشخصية:

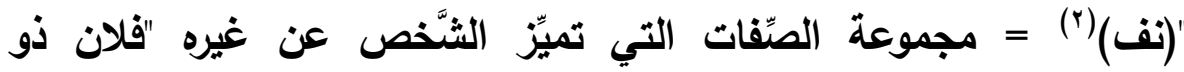
شخصيّة قويّة"، "ذو شخصيّة متميِّة"، "لا شخصيّة له": ليس فيه ما يميِّنه

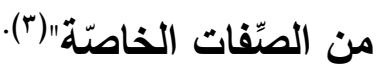

ومع ذلك فقد اختلف علماء النفس في وضع تعريف دقيق للشخصية، فلا يوجد تعريف واحد محدد للشخصيّة؛ حيث إنّ هناك العديد من الدراسات

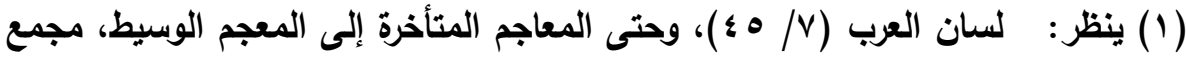

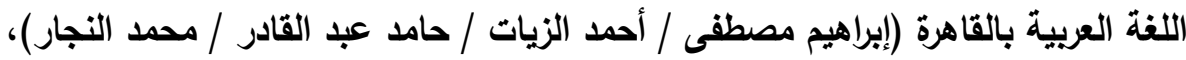

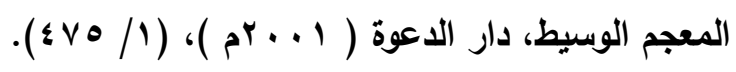

(Y) نف= (علوم النفس)، كما في مقدمة معجم اللغة العربية المعاصرة، دـ أحمد مختار عبد الحميد عمر (المتوفى: ؟Y \& اهـ) بمساعدة فريق عمل، الناشر : عالم الكتب، الطبعة:

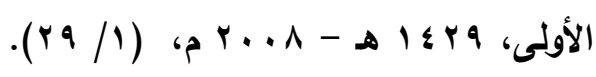

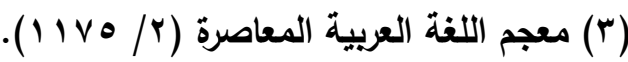

\section{9}

جلة كلية اصول الاين والاعوة / العدد السابع و الثلاثتون 9 ـ ب م ـ الجزء الاول 
والنظريّات التي وضعت تعاريف متعدة للشخصيّة، وحيث إن البحث في علم النفس ليس من تخصصنا؛ فنكتفي بتعريف من أكثر التعريفات قبولًا: تعريف

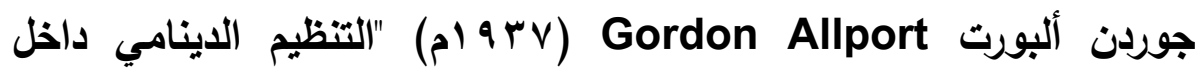
الفرد، لتلك الأجهزة التفسية الجسمية التي تحدد طابعه الخاص في توافقه لبيئته"(1)، والمراد بـ"التنظيم الدينامي" الطبيعة الارتقائية للشخصية.

ثم طوَّر ألبرث تعريفه في (1 99 (م) إلى: "التظيم الدينامي داخل الفرد، لتلك الأجهزة النفسية الجسمية التي تحدد خصائص سلوكه وفكره"(ץ)؛ علمًا بأن كثيرًا من المؤلفين لا يذكرون تعريف الشخصية، إلا أن القراءة المتأنية لتطبيقهم تكشف أن تعريف "ألبورت" يسير عليه الكثيرون صراحة(ז). ويعود عدم تعريف بعض علماء النفس للشخصية إلى وضوح الدلالة في الأهن؛ فإن الغرض من التعريف التمييز بين المحدود وغيره.

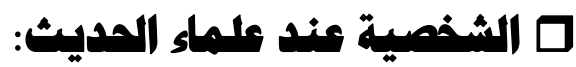

ينبغي أن يعلم أولًا أن علماء الحديث والذين أصَّلوا قواعد المصطلح لم

يتكلموا -في حدود الاستقراء والبحث- من قريب أو من بعيد عن وضع حد للشخصية، ومن ثم فالمصطلح لم يرد في كتبهم، وإنما تكلموا عن أفراد وآحاد؛ كالرواة والمُحدِّثِن، واهتموا ببحث الصفات التي لها تعلُّقُ بالرواة؛ بما

(1) الأبعاد الأساسية للشخصية (ص: 9 ؟).

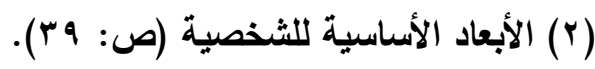

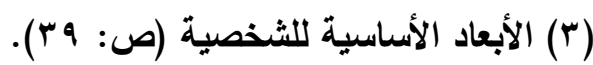


يعرف بأحوال الرواة أو علم الجرح والتعديل.

\section{ם التعريف باعتباره لفظ هركب:}

"السمات الثخصية": مصطلح حادث يختلف باختلاف مجال دراسته والعلم الذي يتناوله؛ فالسمات الثخصية عند علماء النفس لها تعريفات عدة، نكتفي منها بتعريف جامع، وهو: "مجموعة من الخصائص النفسية

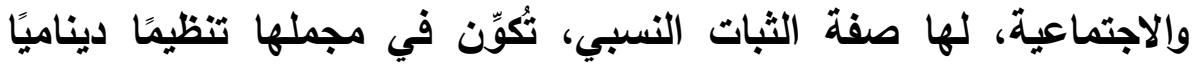
متكاملًا، يمكن في ضوئها وصف الثخص والتنبؤ بسلوكه بدرجة كبيرة من

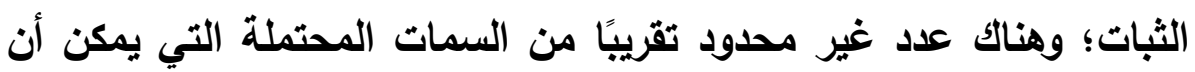
تستخدم لوصف شخصية، ومع ذلك فهناك مجموعات معينة من السمات

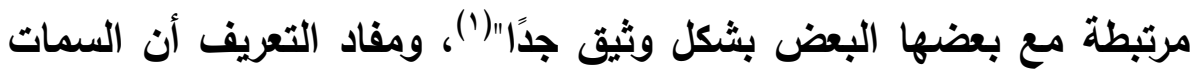

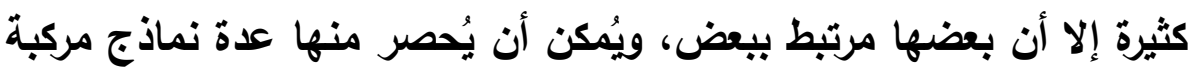

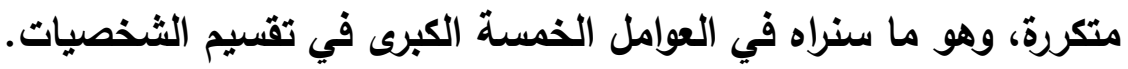

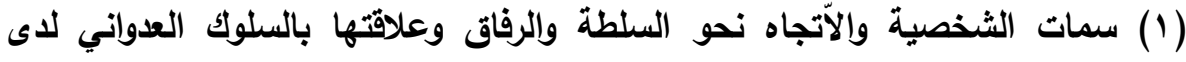

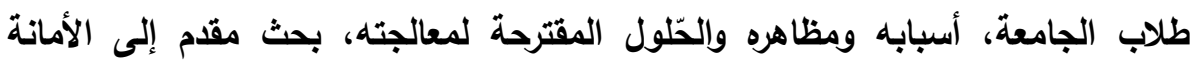

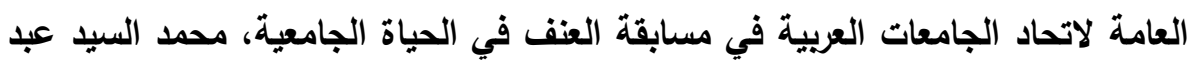

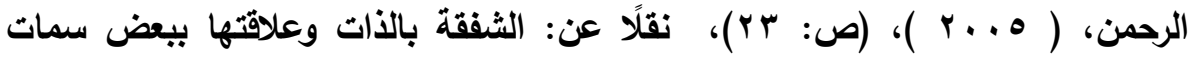

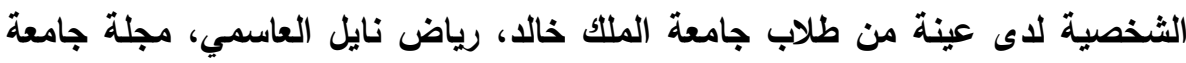

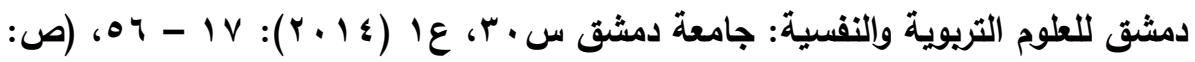




\section{ه أما التعريف عند علماك الفقه والمديث:}

فقد قدّمنا أن المُحدِّثِن لم يُجاوزوا في استعمال السمة المعنى اللغوي، كما

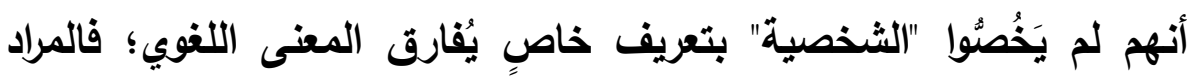
بالسمة الثخصية في كلامهم -على ندرته- يوافق المغنى اللغوي، إلا أنه بهانه

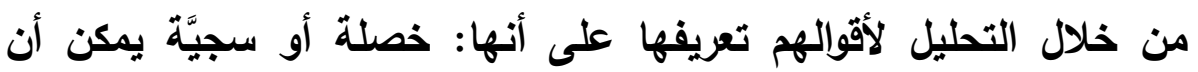
يعتمد عليه في التفريق بين شخص معيَّن وآخر، ويمثل ذلك علامة يتمايز بها الناس بعضهم على بعض.

وعلى هذا؛ فإِذا أردنا تأسيس مصطلح: "السمات الثخصية للمُحدِّث"؛ فيُمكن القول بأنها: "مجموعة الخصال والطباع التي توجد في كيان الراوي أو توانين

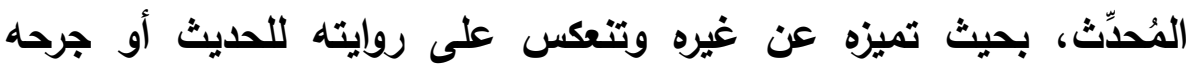

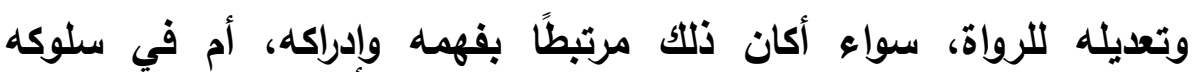
ومشاعره وتصرفاته، أو حتى مظهره الخارجي بالإضافة إلى القيم والرغبات

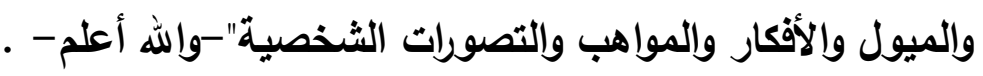
ه تعريف الأمَدَثِ. الأمَدِّثُ لغة: هو اسم فاعل من التحديث، وقد نصَّ ابن منظور على أنه

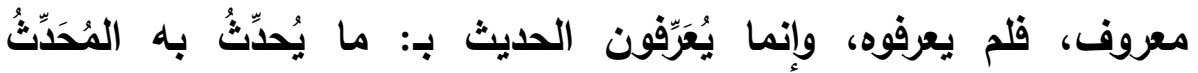

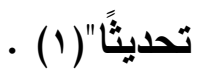

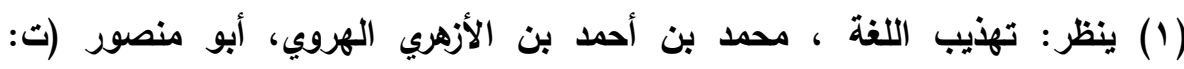

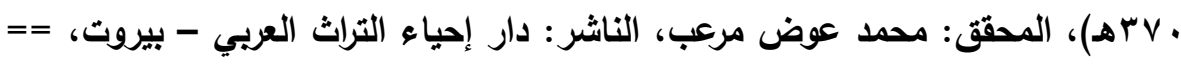


المُمَدَّث اصطلاحا: اختلف أهل العلم في تعريف المُحَدِّث على ثُلاثة أقوال: القول الأول: قول ابن سيد الناس (ت ع V هـ) عن المُحَدِّث أنه: "من

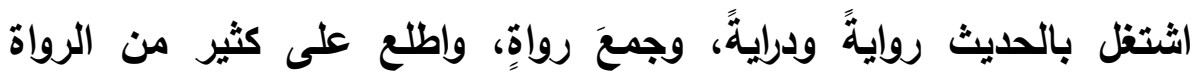

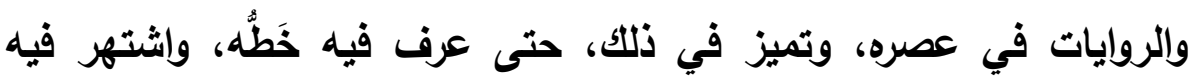

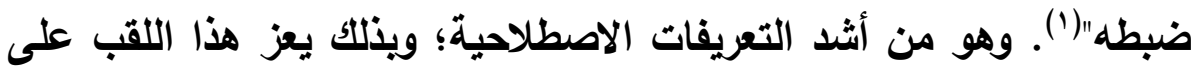

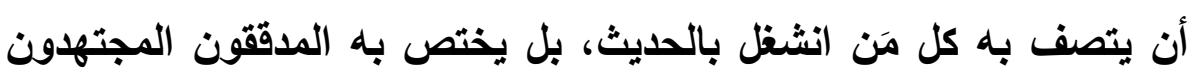
في هذا العلم.

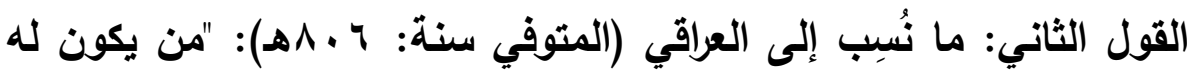

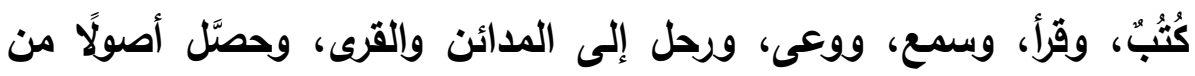

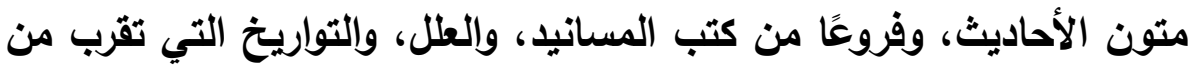

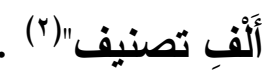

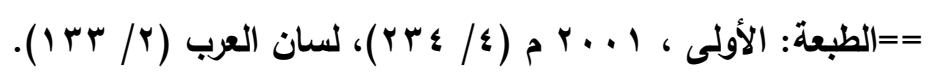

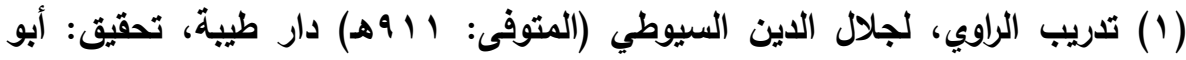

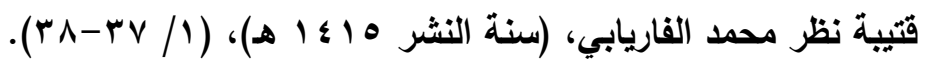

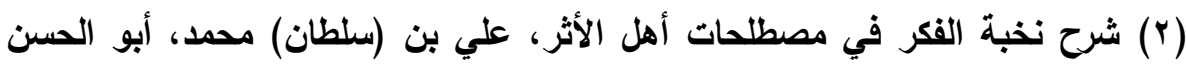

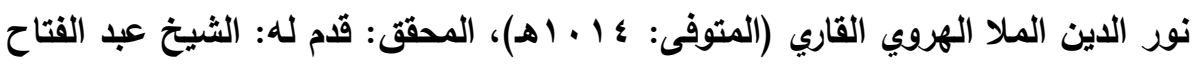

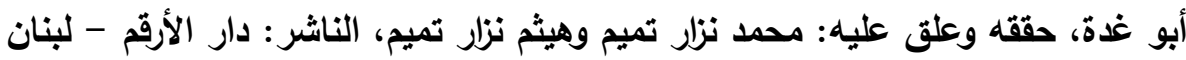

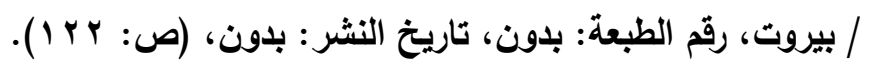

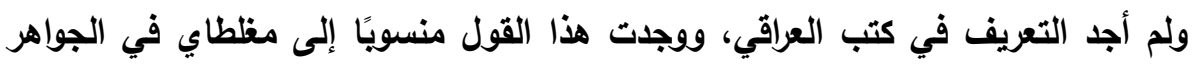

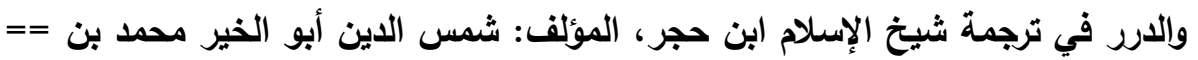


وهذا التعريف يختص برواية الحديث وجمعه وحفظه، بصرف النظر عن اجتهاد صاحبه، وكأنه مرادف لمعنى الراوي، فهو من أيسر التعريفات.

القول الثالث: قول الجزري: "كل من تحمل الحديث رواية، واعتنى به درية"( (1). وهو أوسط الأقوال، وفيه الاعتناء بدرية الحديث.

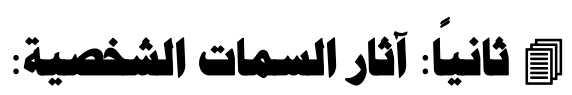
وضع علماء النفس تقسيمات السمات الثخصية تحت ما أسموه بالعوامل الخمسة الكبرى للثخصية.

\section{- تعريف العواهل الفمسة الكبرى للشفمية:}

يمكن تعريفها بأنها: "خمسة متغيرات مختلفة تصف الثخصية وصفا دقيقًا،

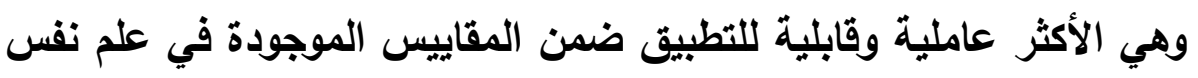

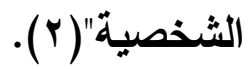
ولأن الثخصية بانفعالاتها لها صور كثيرة؛ فقد اختلفوا حول هذه السمات الكبرى، وما يتفرع منها، ومن هنا نثأت العديد من النظريات والتقسيمات

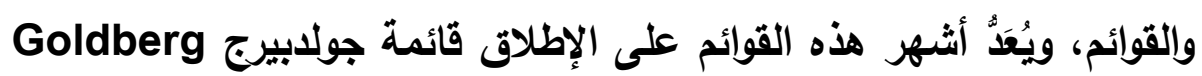

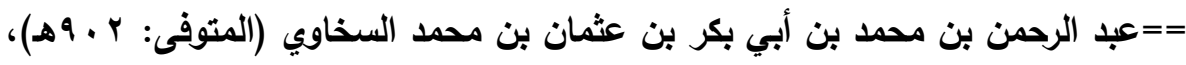

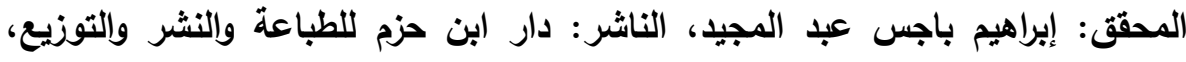

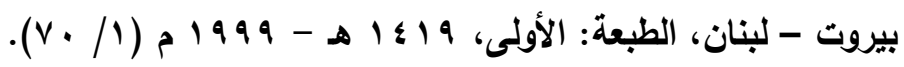

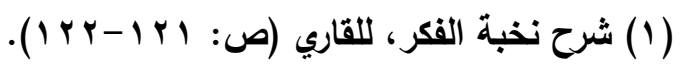

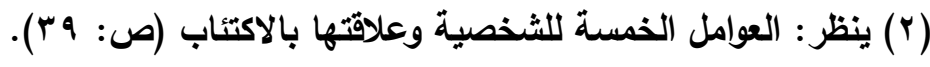
مجلة كلية اصول الاين والدعوة / العدد السابع والثلاثتون 9 اب بام ـ الجزء الاول 


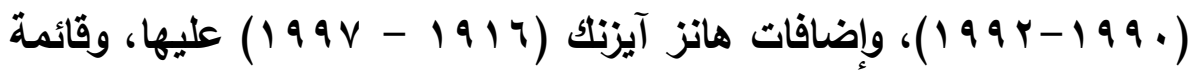
كوستا وماكري Costa \& McCrae (19^レ-19^0) وسميث وسنل Smith \& Snell وهذه العوامل تمثل مجموعات رئيسة من السمات يقع تحت كل منها مجموعة من الخصال والسجيات والأحوال، فنذكرها على طريقة علماء النفس، ثم ما يندرج تحتها من سمات في المُحَدِّث. Neuroticism (N) العصابية وفي مقابلها الاستقرار الانفعالي Emotional stability: العصابية تمثل العواطف السلبية التي تجتاح الإنسان من حين لآخر كتقلب المزاج، وعدم الاستقرار العاطفي، وأوجهها الستة هي: القلق، الغضب، الاكتئاب، الوعي الأتي -والمقصود به هو أن يكون الثخص واعيا بذاته بحيث يشعر بالإحراج والخجل كل مرة في مواقف لا تستحق، كذا الانزعاج أثناء التواجد مع الآخرين، أو ليس لايه تقدير لذاته، الاندفاعية، العدائية، واللهشاشة والمقصود بها- الاعتماد على الآخرين للحصول على الاعم

(1) ينظر: العوامل الخمسة للشخصية وعلاقتها بالاكتئاب (ص: 9 ب)، وينظر أيضًا: العوامل الخمسة الكبرى في الثخصية لذى الموهوبين والعاديين، عبدالرحمن حطين

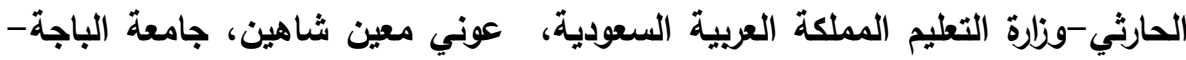

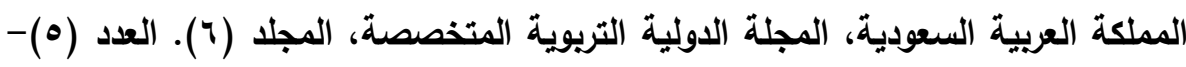

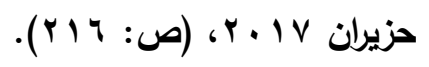


والمساعدة، والصعوية في حل المشاكل الشخصية--. ويحسب بحث آيزنك في الأصل البيلوجي والفيسيولوجي للسمة: فالشخص الأي يميل جهازه العصبي السمبثاوي للنشاط أكثر فيُعطي سمات للشخصية تظهر كل حين كسمات ملاصقة للشخص مثل سرعة الغضب، والكآبة،

والتشاؤم، والتوساوس، والتوتر والقلق (1).

r - الانبساطية Extroversion والتفتح Openness وفي مقابلها

الانطوائية والتحفظ Inclusion

سمة مرتبطة بالنشاط الاجتماعي، والتفاعل مع الآخرين، حب للتجمعات، والصخب والنشاط وغيرها من السمات، وأوجهها الستة هي: الافء، الألفة، الحزم، النشاط، طلب الإثارة، والعواطف الإيجابية. على الطرف الآخر؛ تجد الانطوائي الأي يفضل الاستقلالية، ويرتاح للوحدة، ويُكوّن عددًا أقل من العلاقات.

ويينهما الشخص المتكافئ؛ قادر على التحرك بسهولة مع الآخرين، كما هو

(1) ينظر: الأبعاد الأساسية للشخصية (ص: 19 ب)، العوامل الخمسة الكبرى (ص:

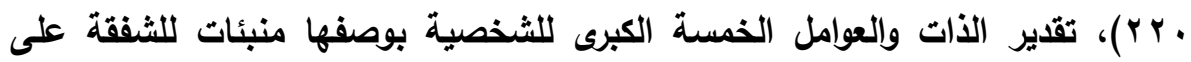

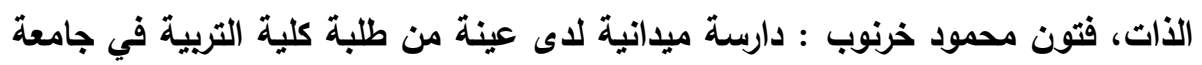

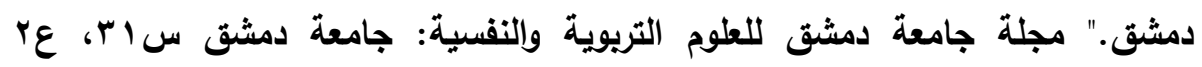

$$
\text { (rar: ( ) : (r.10) }
$$


قادر على العمل في عزلة تامة(1). r- الطيبة أو المقبولية Agreeableness وفي المقابل الثك وعدم التعاون: الطيبة مجموعة من السمات الشخصية التي تركز على العلاقات

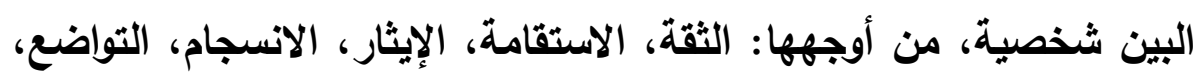
التعاطف.

والطيّبُ يتبنى فلسفةً إيجابية في الحياة، ويحرض على أن يكون نافعًا ومفيدًا، ويثق في الآخرين ويتوقع منهم الخير. وعلى الطرف الآخر؛ تجد مجموعة من السمات العكسية، كالتحدي، الثك، الحذر، التنافس، العدوانية، والمتصف بها يركز على حاجاته الثخصية أكثر من مراعاة حاجات الآخرين، ويتكبر ويتعالى ويتسلط. وهناك منطقة وسطى بين الطرفين يسمى صاحبها الشخص المفاوض؛ وهو شخص حَذْرُ لا يثق بالآخرين، لكن لبق ويرغب بالمساعدة، وقادر على الانتقال بين القيادة والتبعية حسب متطلبات الموقف(Y). ع - يقظة الضمير Conscientiousness وفي المقابل عدم الاكتراث:

(1) ينظر: الأبعاد الأساسية للشخصية (ص: 1 إ)، العوامل الخمسة الكبرى في

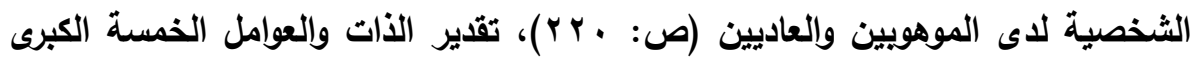
للشخصية (ص: ب r r ). (Y) ينظر: العوامل الخمسة الكبرى في الثخصية لدى الموهوبين والعاديين (ص: • ب r))، تقدير الذات والعوامل الخمسة الكبرى للشخصية (ص: ؟ ؟ ب ). جلة كلية اصول الدين والدعوة / العدد السابع و الثتلاثتون 9 ا ـ بم ـ الجزء الاول 
وهي مجموع السمات الثخصية التي تركز على ضبط الذات والترتيب في السلوك والالتزام في الواجبات والاجتهاد المتعلق بالمثابرة والتنظيم، وأوجهها

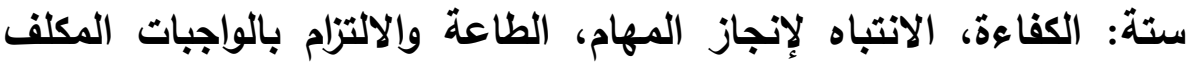

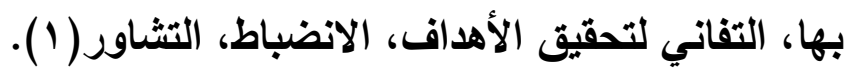
ه- الانفتاح على الخبرة Openness to Experience وفي المقابل الانغلاق على الخبرات السابقة: وهي مجموع السمات الثخصية التي تركز على القيم اللاتسلطية والانفتاح

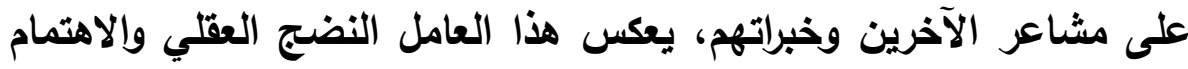
بالثقافة، واللارجة المرتفعة تدل على أن الأفراد خياليون، ابتكاريون، يبحثنون

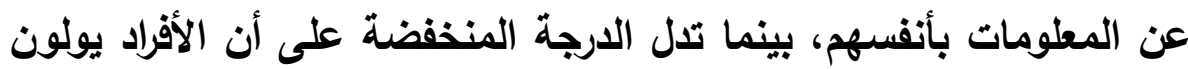
اهتمامًا أقل بالفن، وأنهم عمليون في الطبيعة.

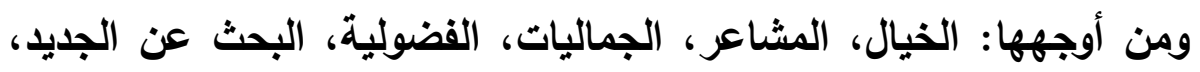

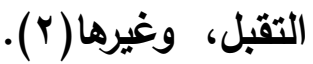

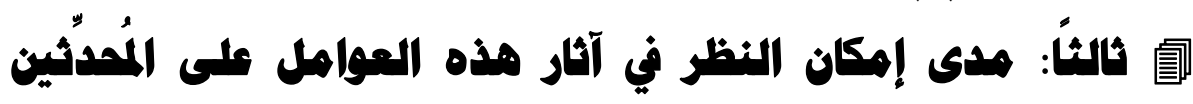
ووضع قواعد ضابطة ومداخل للدراسة:

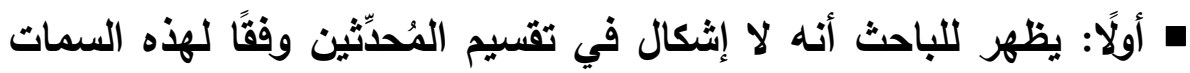
(1) ينظر : العوامل الخمسة الكبرى في الثخصية لاى الموهوبين والعاديين (ص: • ب ب)،

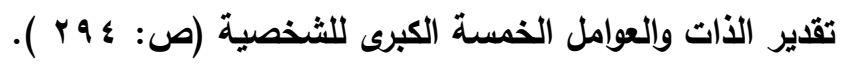

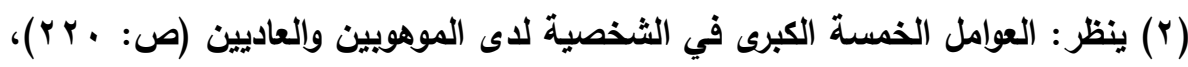

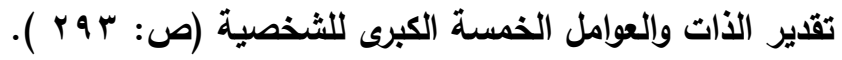




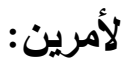

الأول: أن هذه العوامل تنطبق على عموم البشر -على اختلاف حضاراتهم -

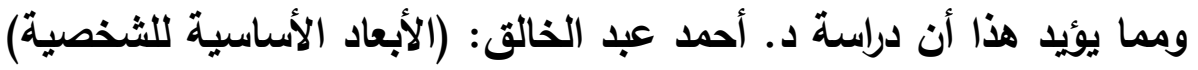

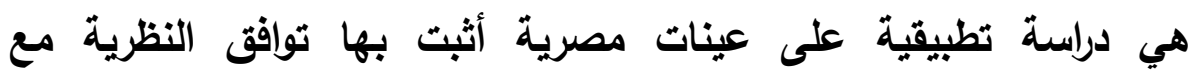

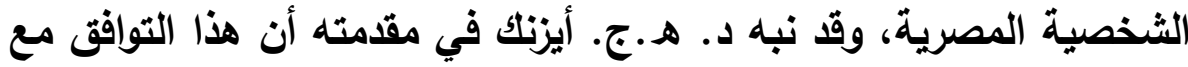

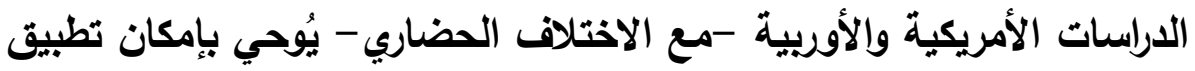
النظرية على أبعاد أوسع( ( ). وهذا هو أحد مداخل الدراسة في التطبيق الجزئي على المُحدِّثِن. الثاني: أن علماء الحديث كانوا -بطبيعة عصورهم - يعتمدون الطب القديم، وكان هذا الطب الأبقراطي يتناول تقسيم الشخصيات إلى أنماط أو أمزجة

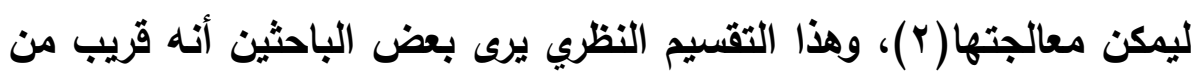

(1) ينظر: مقدمة د. هـ.ج. أيزتك لكتاب: الأبعاد الأساسية للثخصية، د. أحمد عبد

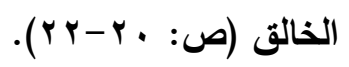

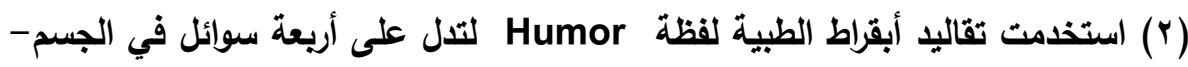

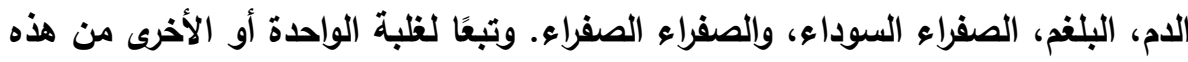

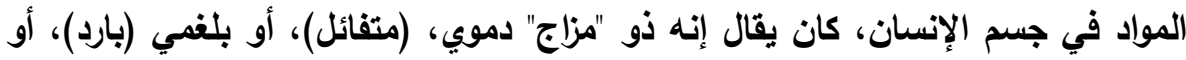

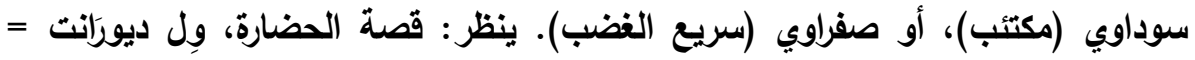

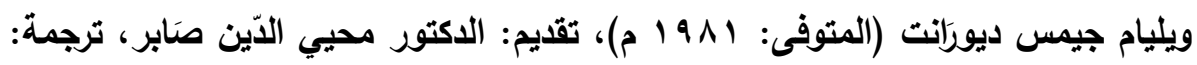

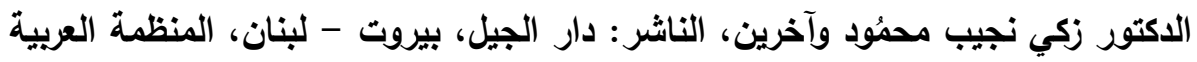

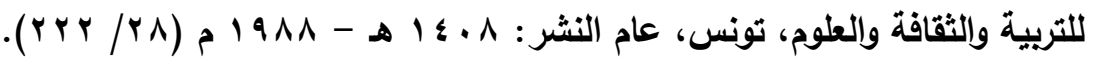

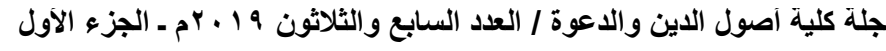


نظرية العوامل الشخصية الخمسة الحديثة نسبيًا، والتي فصئلناها قبل قليل، وعلى أي حال لا شك أنه فتح الباب لهذا التفكير النمطي( (1).

وقا صحَّح ابن سينا رأي أبقراط في هذا التقسيم، ودلَّل عليه، ونَظَمه في أرجوزة، وجاء ابن رشد فشرحها، وفيها وصفه للأمزجة بقوله:

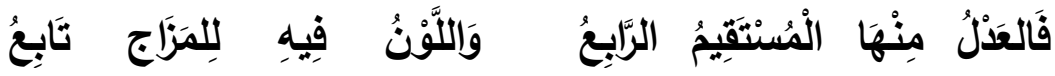

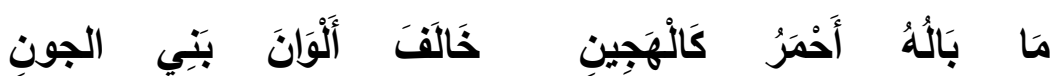

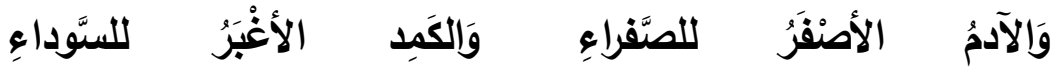

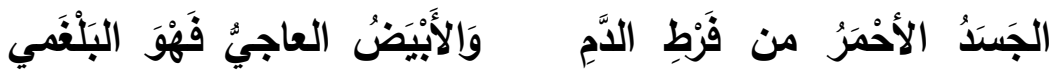

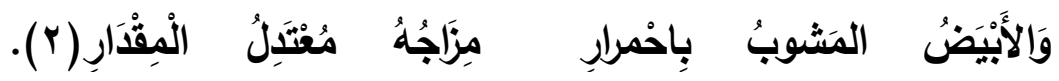

(1) ينظر: نظرية الأنماط Types Theory من: علاقة بعض سمات الشخصية بانحراف الأحداث في مدينة الرياض، سعيد رفعان العجمي، دراسة لاستكمال متطلبات

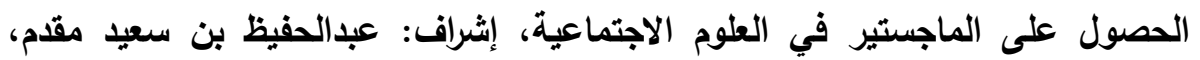

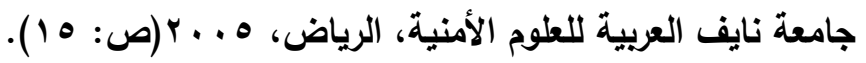

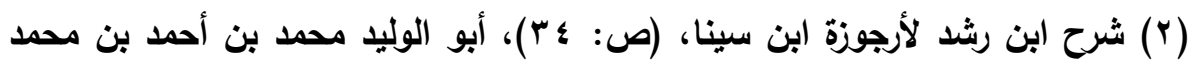

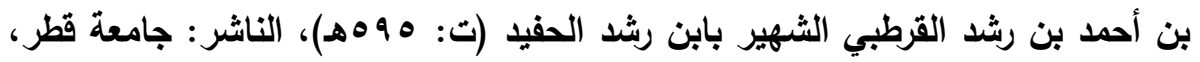

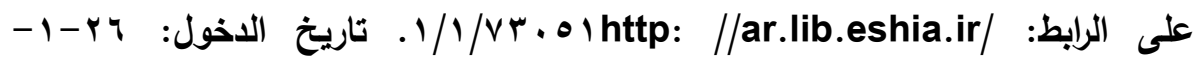
.$r .19$

وكانوا يعتمدون على اختلاف هذه الأمزجة في علاج الأمراض. ينظر: الحاوي في الطب،

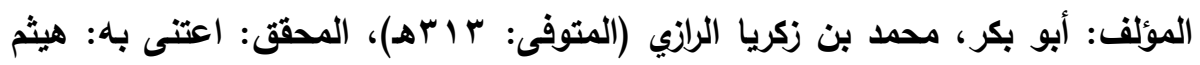

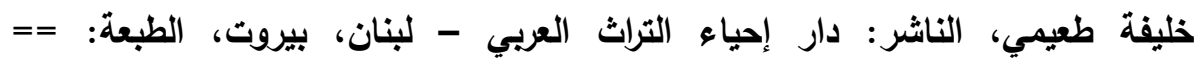

$$
\text { مجلة كلية اصول الدين والاعوة / العدد السابع والثلاثون } 9 \text { ا ـ بم ـ الجزء الاول }
$$


وقد استعمل بعض الفقهاء هذه الأمزجة في التفريق والتمبيز( (1).

ثانيًا: إن هذا التقيم الخماسي للشخصيات أغلبي ظني، لا كلي ولا قطعي، إلا أنه من أعمِّ الدراسات، وقد يتداخل في الشخص أكثر من نموذج، ومحل دراسة الأمر هو كتب الدراسات النفسية(r).

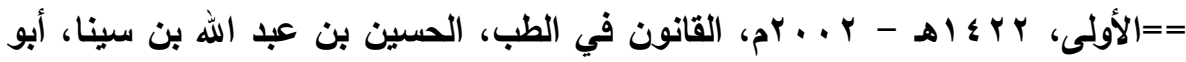

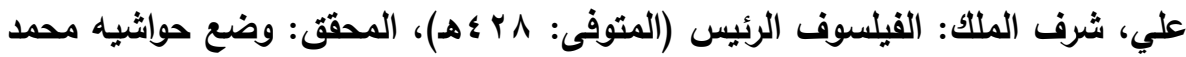
أمين الضناوي، بلون بيانات نشر. (1) ينظر على سبيل المثال: أنوار البروق في أنواء الفروق، أبو العباس شهاب الدين

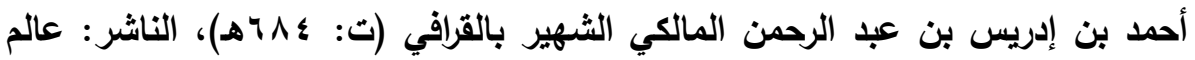

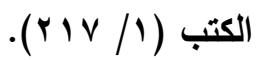
(Y) ينظر: العوامل الخمسة للشخصية: وجهه جديدة لدراسة وقياس بنية الشخصية، د. هشام حبيب الحسيني محمد، أستاذ علم النفس التريوي المساعد، المركز القومي

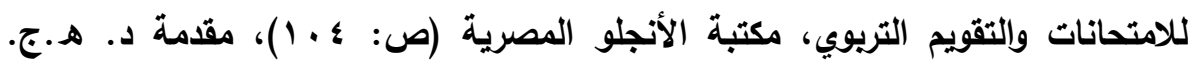

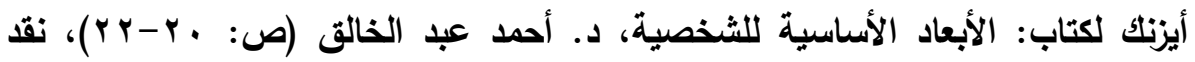

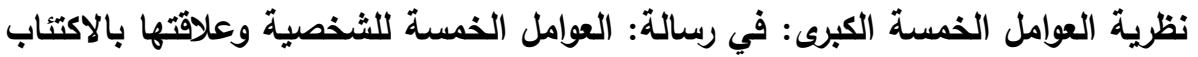
لدى المرضى المترددين على مركز غزة المجتمعي - برنامج غزة للصحة النفسية، الطالب:

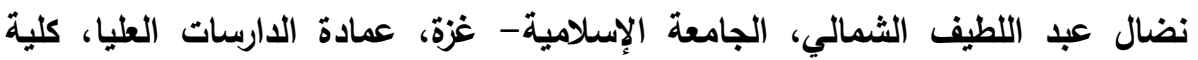
التربية-قسم علم النفس والإرشاد النفسي، إثراف الدكتور: نبيل كامل دخان، قدم هذا عادها البحث استكمالًا لمتطلبات الحصول على درجة الماجستير في التربية تخصص: الصحئة الصحة

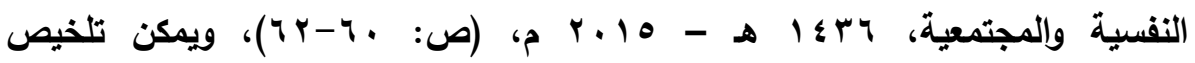
الانتقادات الموجهة لنظرية العوامل الخمسة على وائمعه شكل نقاط:

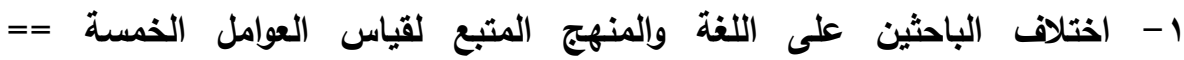


ومن العجيب تفطن القدماء إلى تداخل الأمزجة، والثخصيات؛ قال

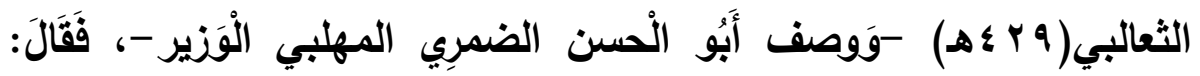

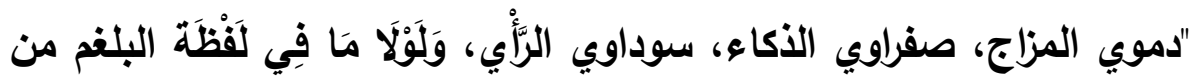

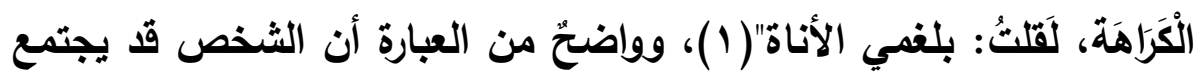

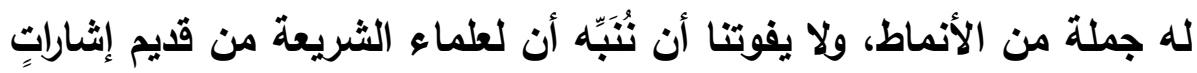

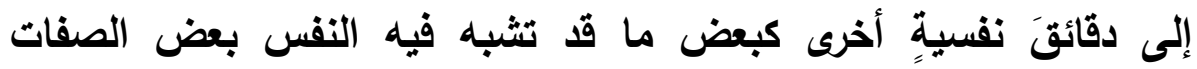

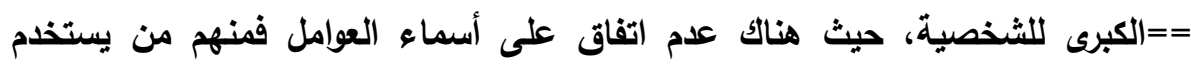
الأعداد الرومانية أو الأحرف الأبجدية أو الأسماء.

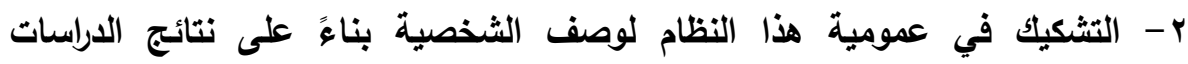
الحضارية التي أثنارت إلى عدم قابلية العوامل الخمسة الكبرى للظهور في بعض الثاء الثقافات والحضارات مثل روسيا وأيسلندا والقلبين. r- حصر عدد العوامل في خمسة عوامل الأمر الذي يعتبره البعض قليلًا والبعض الآخر

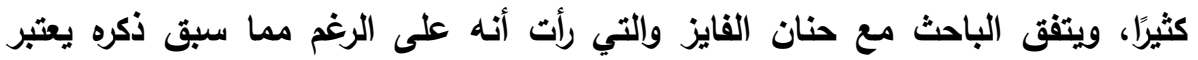

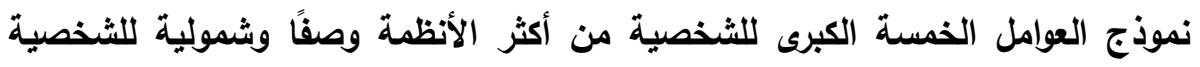

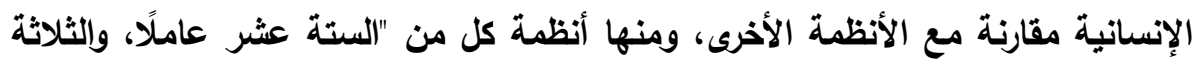

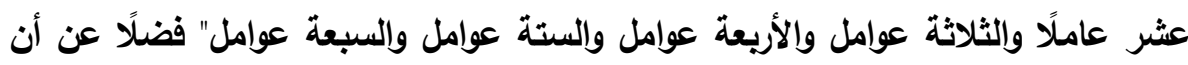

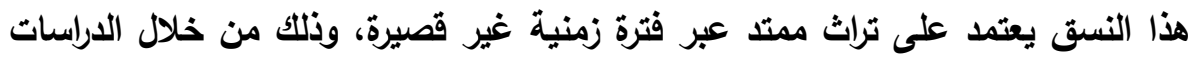

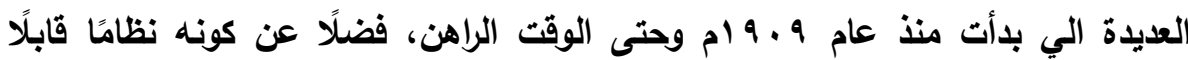
للتكرار على الرغم من تعدد طرق القياس، وتغير العينات والحضارات. (1) خاص الخاص، عبد الملك بن محمد بن إسماعيل أبو منصور الثعالبي (المتوفى:

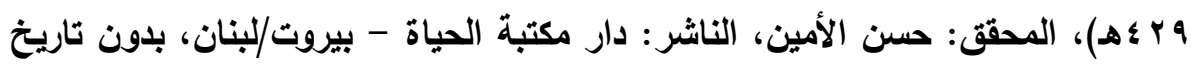

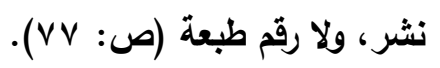


النفسية لبعض الحيوانات(1). م ثالثًا: ما يتعلق بإمكان التطبيق على المُحدِّثين:

مع أن العوامل الخمسة المذكورة لها درجة من العمومية إلا أن البيئة لها كبيز تأثير في الأنماط الأخلية(Y)، ويالتالي، فلا با من ملاحظة هذه التأثيرات البيئية والدينية وغيرها في شخصيات المُحدِّثني؛ فقد يؤدي إلى نوع من تداخل أنواع الشخصيات. ومما يُقر هذا أن بعض الثقافات لم تقبل نظرية العوامل الخمسة كروسيا وأيسلندا والفلبين(r) مما يدل على أنه لا بـ من مراعاة الفروق البيئية والاينية والحضارية ونحوها (ع)؛ فمثلًا من العوامل التي تؤثر في الثخصيات

(1) ينظر على سبيل المثال: إحياء علوم الدين، أبو حامد محمد بن محمد الغزالي

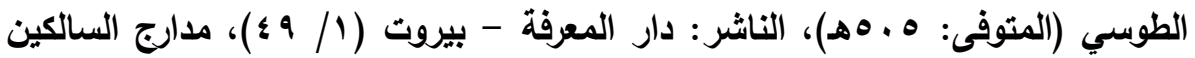

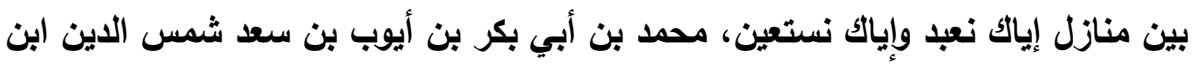

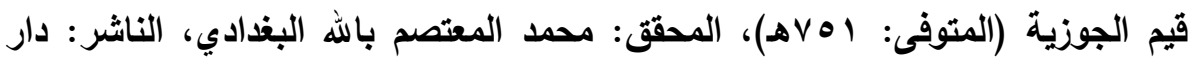

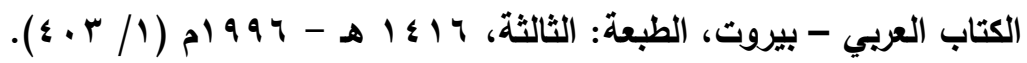

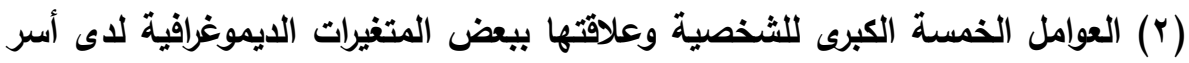
المعاقين عقليًا-دراسة ميدانية على أسر التلاميذ المعاقين عقليًا بمعه المستقبل عطبرةد. مجذوب أحمد مجمد أحمد قمر، جامعة دنقلا-كلية التربية- السودان، مجلة الدارسات

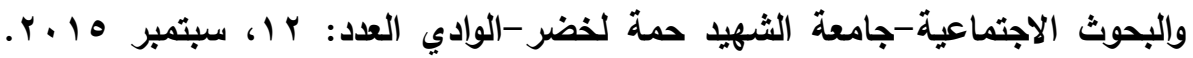

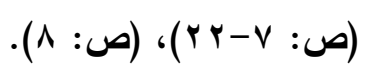

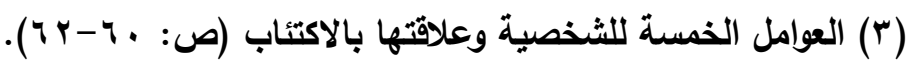
(؛) وقد أجرى النفسيون دراسات تتعلق بعلاقة التدين بأنماط الثخصية، ينظر على == بلابه 
وسلوكها بوضوح: "الخوف من الله"، فيكون الثخص مرِحًا جدًا ثم تُركه

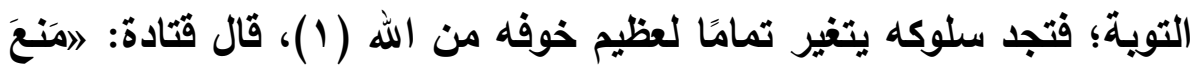

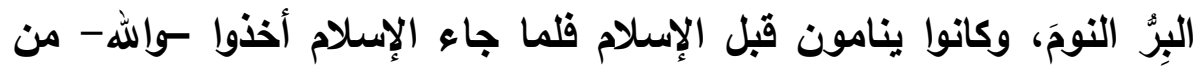

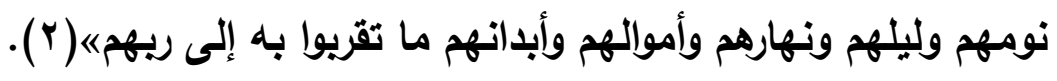
ولعل ذكر الأمثلة التطبيقية يُبين مقصودنا بصورة أوضح. | رابعًا: ما يتعلق بالحياة الثخصية والاجتماعية للمُحدِّثين:

من الأهمية بمكان أن يؤكد البحث على أن كتب التراجم كان لها غرضٌ

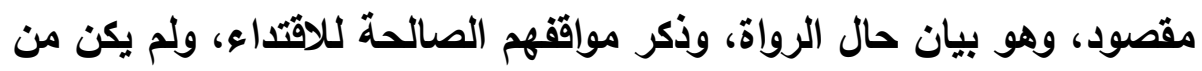

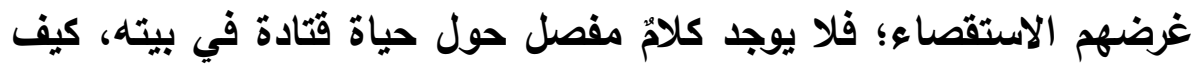

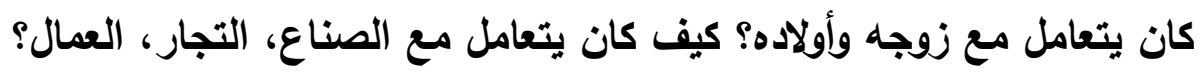

== =بيل المثال: التدين وعلاقته بالعوامل الخمسة الكبرى للثخصية لاى عينة من المراهقين الكويتيين، أحمد محمد عبدالخالق، وشيماء وليد الجوهري. مجلة الطفولة الكية

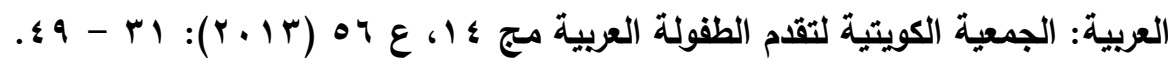

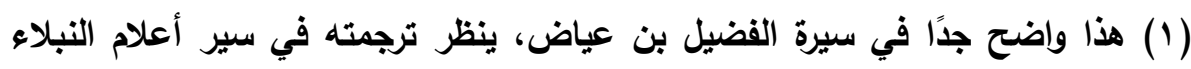

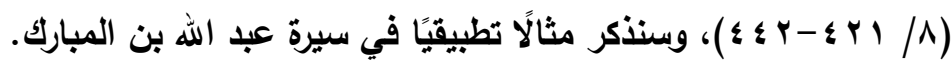

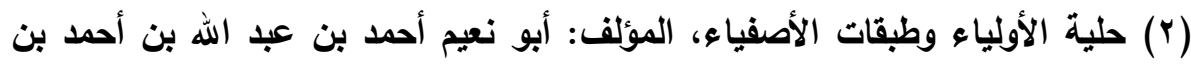

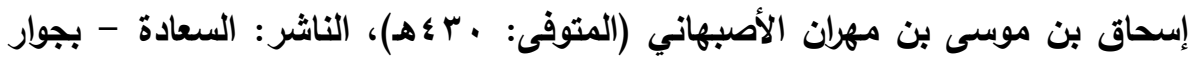

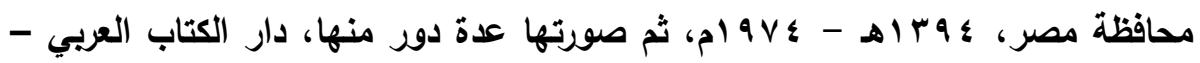

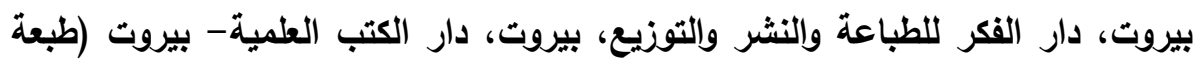

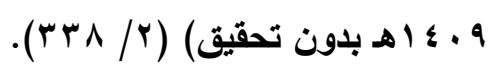


ويالتالي؛ فالارس لحياتهم يحتاج إلى تدقيق كبير؛ ليأخذ بعض سماتهم من

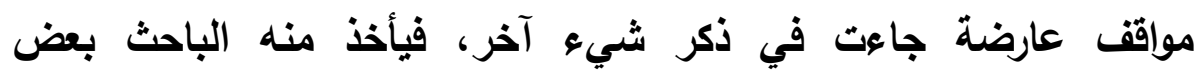

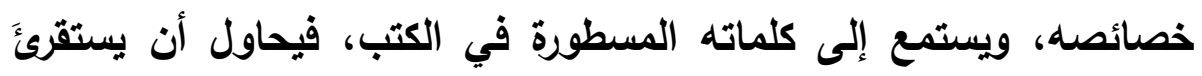

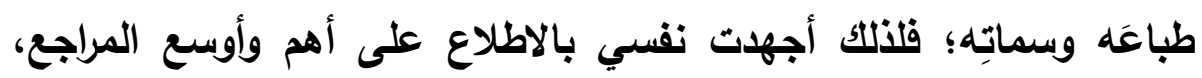
وقراءة الترجمة كاملة؛ لأجل هذا الاستخلاص، ومع هذا هذا فهو استقراء جزئي؛

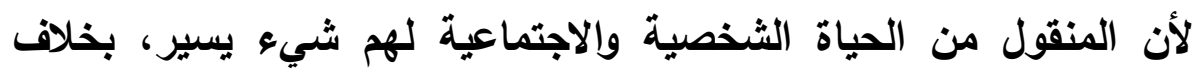
النبي ويُمكن للقارئ أن يتنبه للمقصود إذا طالع مثًاً "الأغاني" لأبي الفرج

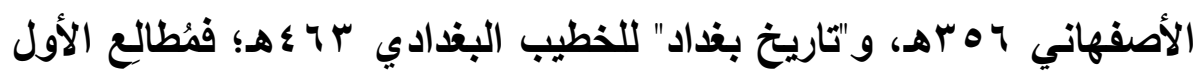

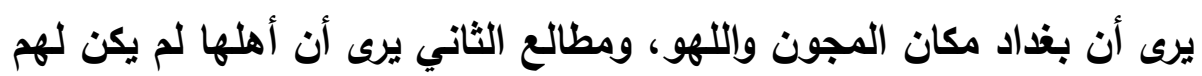
شغل سوى العلم، ولا يُنجيك من هذا التصور المتناقض إلا إحكام ما أراد البحث التنبيه إليه في هذا الموضع، ويالله توفيقي وعليه معتمدي.

$\operatorname{sen} \Delta \cos$ 


\section{المبمث الأول

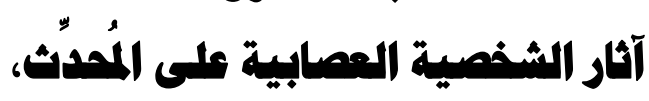 \\ (سمة الغضب) أنموذجةًاً}

سبق التعريف بالعوامل الكبرى الخمسة: العصابية، ويُقابلها: الاستقرال

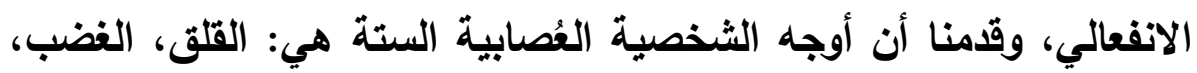

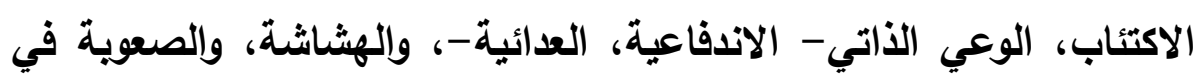
حل سمة الثخصي.

\section{مأولا: تعريف الغضب:}

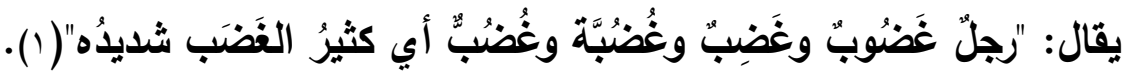
ومعلوم أن سمة الغضب تختلف من شخص لآخر، والغضب بنفسه ليس

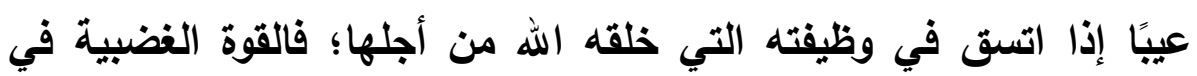

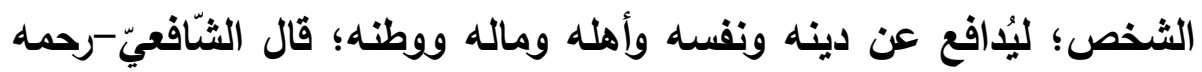

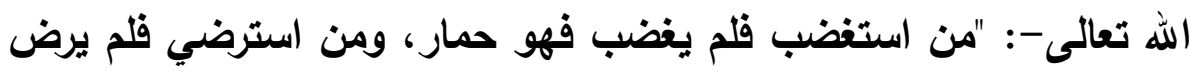

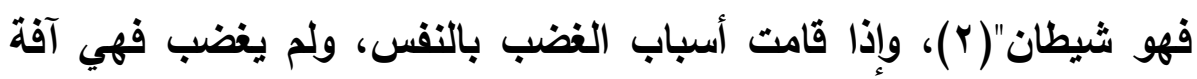
تحتاج إلى علاج؛ قال الغزالي: "فمن مال غضبه إلى الفتور حتى أحس من

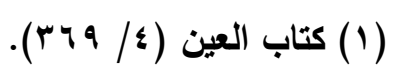

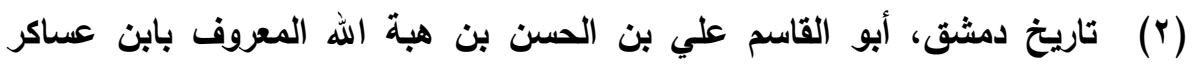

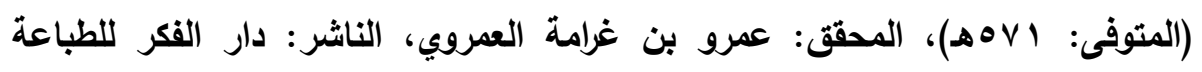

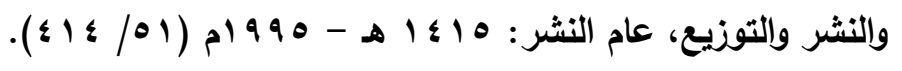


نفسه بضعف الغيرة وخسة النفس في احتمال الأل والضيم في غير محله، فينبغي أن يعالج نفسه حتى يقوى غضبه، ومن مال غضبه إلى الإفراط حتى جره إلى التهور واقتحام الفواحش، فينبغي أن يعالج نفسه لينقص من سورة الغضب، ويقف على الوسط الحق بين الطرفين؛ فهو الصراط المستقيم، وهو أرق من الثََّّرة وأحد من السيف، فإن عجز عنه، فليطلب القرب منه"(')، وقد كان الأنبياء -عليهم السلام - يغضبون حين تنتهك حرمات الله -عز وجل-؛ فهذا موسى -عليه السلام- يغضب حينما رجع فوجد قومه يعبدون عجلًا

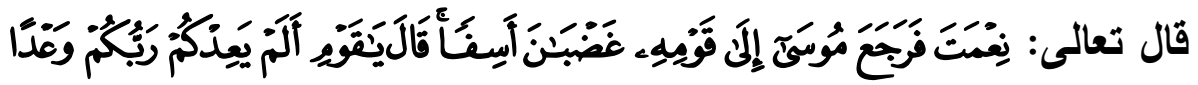

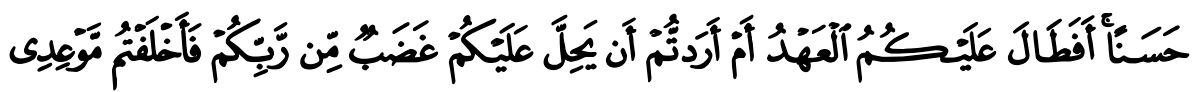
3.

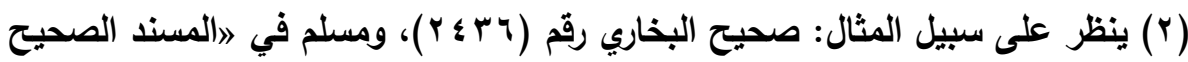
المختصر بنقل العدل عن العدل إلى رسول الله -صلى الله عليه وسلم-" المسمى صحيح

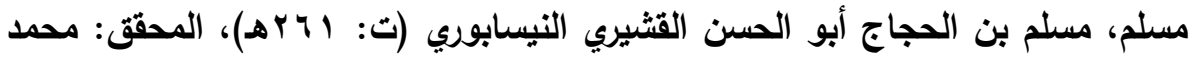

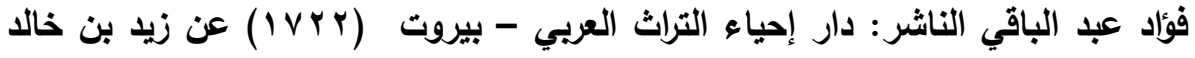
الجهني رضي الله عنه: أن رجلًا سأل رسول الله صلى الله عليه وسلم عن اللقطة، قال:

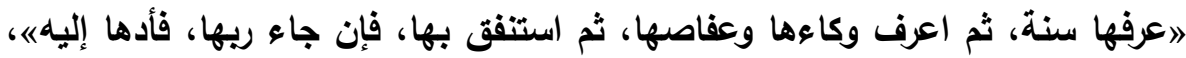
قالوا: يا رسول الله، فضالة الغتم؟ قال: 》خذها، فإنما هي للك أو لأخيك أو للأئبه، قال: يا رسول الله، فضالة الإبل؟ قال: فضضب رسول الله صلى الله عليه وسلم حتى احمرت وجنتاه - أو احمر وجهه - ثم قال: 》الها للك ولها معها حذاؤها، وسقاؤها، حتى يلقاها 
كما غضب الصحابة، ثم التابعون في مواقف معلومة لا تحتاج إلى تتبع.

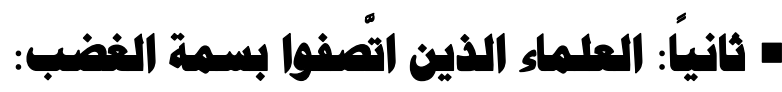
وممن اتصف بهذه الصفة من العلماء:

قتادة بن دعامة السدوسي (IV I هـ) - رحمه الله- سيتم بحول الله وقوته تفصيل الكلام فيه كنموذج تطبيقي لتأثير الغضب على آرائه الحديثية - . الإمام مالك بن أنس -رحمه الله-؛ فقد نُقِل عنه ما يـل على هذه السمة، إنه ويتضح ذلك من وصف عبد الله بن إدريس (Y 19 هـ) -رحمه الله-، قال: "كنت عند مالك بن أنس فقال له رجل: يا أبا عبد الله، إني كنت بالري عند أبي عبيد الله، وعنده محمد بن إسحاق، فسمعته يقول: "اعرضوا عليَّ علم مالك فإني بيطاره؛ فغضب مالك" (1) . ومن النماذج التي تدل على اتصافه بسمة (الغضب): قال مصعب: "سُئيلَ مالك عن مسألة فقال: لا أدري. فقال لله السائل: إنها

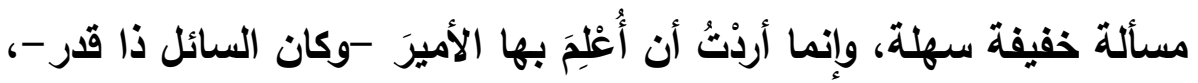
فغضب مالك وقال: مسألة خفيفة سهلة! ليس في العلم شيء خفيف، أما

(1) أخرجه أبو زرعة الرازي في 》الضعفاء《 و 》أجوية أبي زرعة الرازي على سؤالات

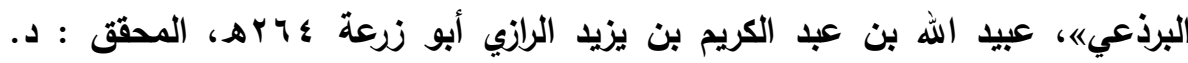

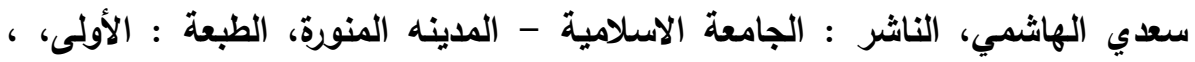

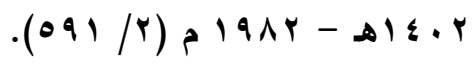




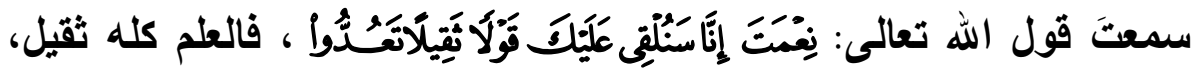
ويخاصة ما يسأل عنه يوم القيامة"( ).

وقال بعضُ ولاة المدينة لمالك: "لم لا تخضب كما يخضب أصحابك؟

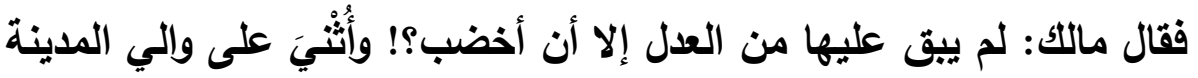

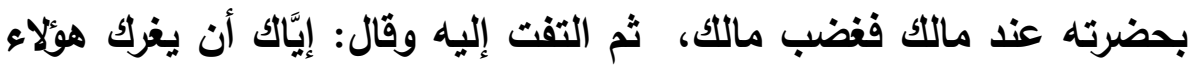

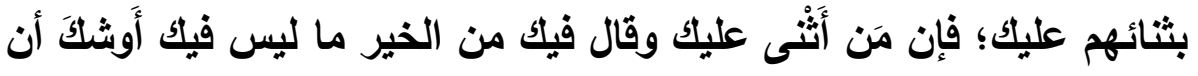

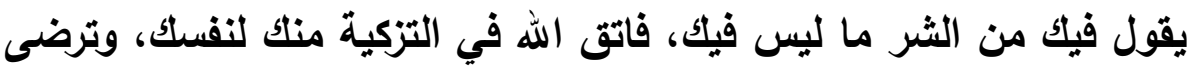
بها من يقولها للك في وجهاك؛ فإنك أنت أعرف بنفسك منهم. فإنه بلغني أن

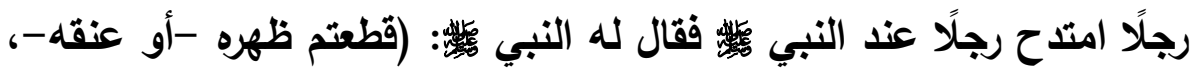

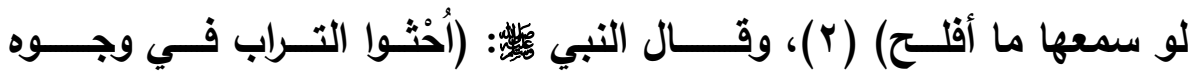

(1) ترتيب المدارك وتقريب المسالك،، ، لأبي الفضل القاضي عياض بن موسى اليحصبي

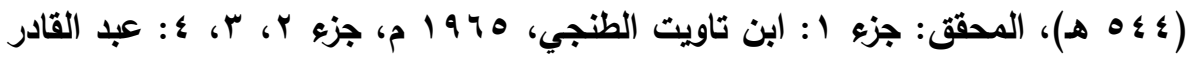

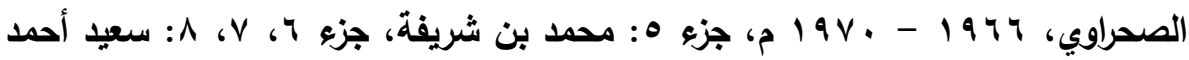

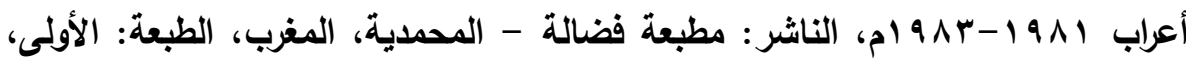
.$(1 \wedge 0-1 \wedge \leq / 1)$ والموافقات، إبراهيم بن موسى بن محمد اللخمي الغرناطي الثهير بالثاطبي (·هVA)،

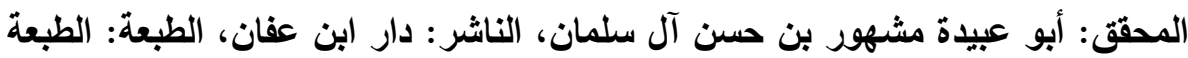

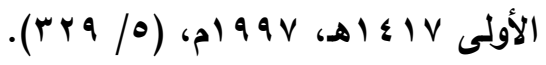

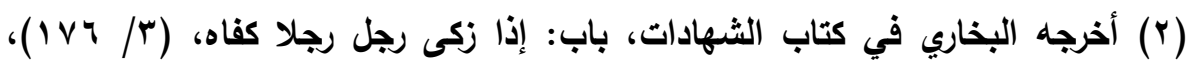

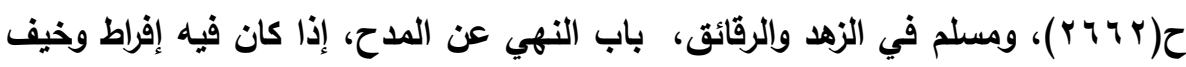

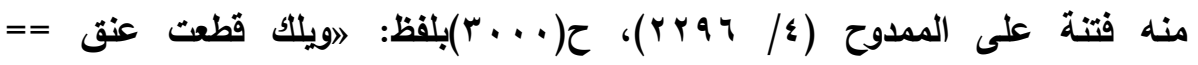




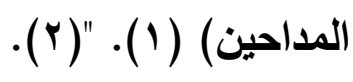

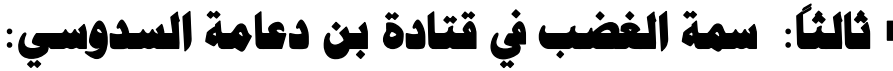

وممن وصفه بالغضب شعبة بن الحجاج ( • 1 1) - رحمه الله-: فقد روى ابنُ أبي حاتم في كتابه قال: "تأ صالح بن أحمد، نا علي بن المديني قال: سمعت بَهْزَ بنَ أسد، قال: سمعتُ همامًا قال: كان شعبة يوقَف قتادة، قال

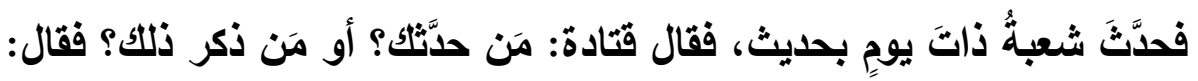
نسألك، فتغضب وتسألنا؟"(r). ومن النماذج الدالة على اتصافه بهذه الصفة: قول وكيع: قال شعبة: "كان قتادة يغضب إذا وققته على الإسناد، قال:

==صاحبك، قطعت عنق صاحبك" مرارا، ثم قال: 》من كان منكم مادحا أخاه لا محالة،

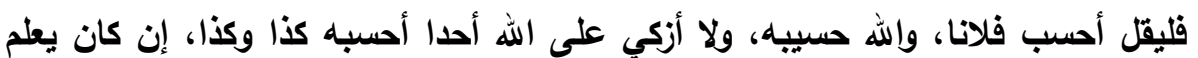
ذلك منه «.

(1) أخرجه مسلم في الزهد والرقائق، باب النهي عن المدح، إذا كان فيه إفراط وخيف

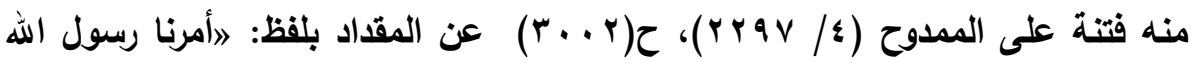

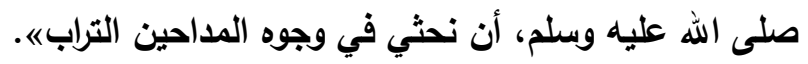

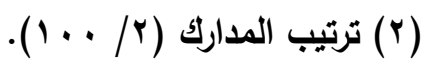

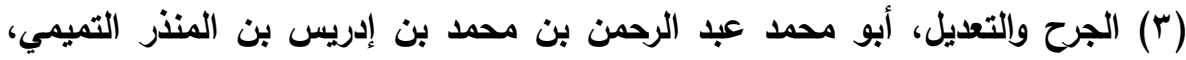

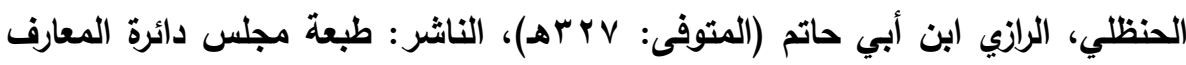
العثمانية - بحيدر آباد الدكن - الهند، دار إحياء التراث العربي - بيروت، الطبئ الطبعة:

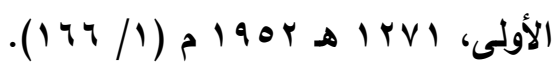


فحدثته يوما بحديث أعجبه، فقال: مَن حدثك؟ قلت: فلان عن فلان، قال: فكان يعده"( )؛ فقد كان شعبة يدقق معه في الأسانيد، ويطلب منه أن يبين ممن سمع، فكان قتادة يغضب إذا طلب منه ذلك. آثار سمة (الغضب) على مرويات قتادة بن دعامة الحديثية:

قدَّمنا أن شعبة كان يستوقف قتادة على الإسناد، وقا رثَّب على ذلك قاعدة؛ فإذا لم يبين قتادة ممن سمع الحديث لم يكتبه شعبة؛ روى ابن أبي حاتم عن علي -يعني ابن المديني- قال سمعت عبا الرحمن وذكر شعبة، فقال: سمعته يقول: "كنت أتفقد فم قتادة، فإذا قال: (سمعت) و(حدثا) تحفظته، فإذا قال (حدث فلان) تركته"(r). نموذج دالٌّ على ذلك:

روى ابن أبي حاتم أن عبد الرحمن بن مهدي يقول: سمعت شعبة يقول: "كنت أنظر إلى فم قتادة، فإذا قال للحديث: (حدثا)، عُنيتُ به؛ فوققته عليه،

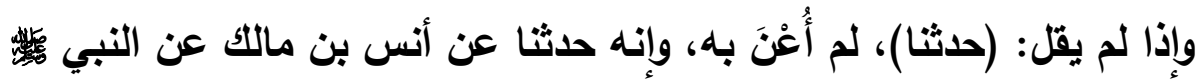
قال: 》سووا صفوفكم؛ فإن تسوية الصف من تمام الصلاة)، فكرهت أن أوقفه

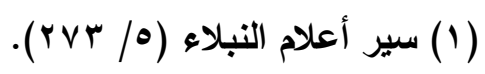

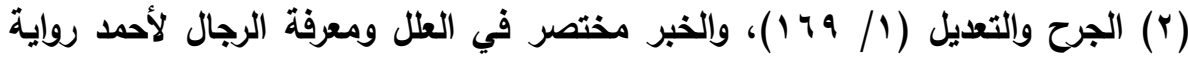
ابنه عبد الله، أبو عبد الله أحمد بن محمد ابن حنبل بن هلال بن أسد الثيباني (المتوفى:

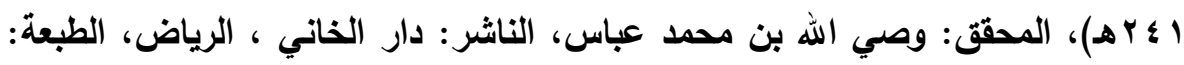

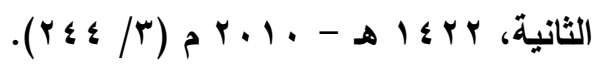


عليه فيفسده علي فلم أوققه عليه"( ).

والخلاصة: أن هذا يوضح لنا أن شعبة - رحمه الله - أصبح لا يسأل قتادة عن السماع؛ لأنه يغضب إذا سُئل! وأصبح شعبة يتتبع كلام قتادة فقط؛ فإذا صرَّح بالتحديث كتبه، وإلا لم يكتب، ولو أن قتادة لم يكن يغضب من السؤال

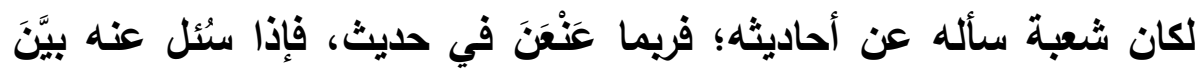
السماع؛ فَقَبل حديثهُ

\section{رابها: مدى وجمد هذه الآثار الثممية المصابية في هياة}

قتادة عمدماً:

لا يخفى على الناظر ظهوز آثار الشخصية العُصابية في سيرة قتادة في

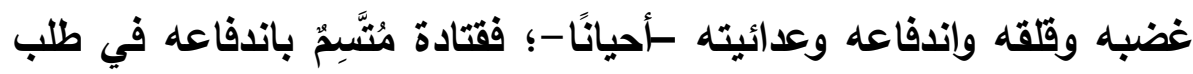
العلم بلا رَوِيَّة(Y)؛ فَنَنْ مطر الوراق: ما زال قتَادة متعلما حتى مات(ب).

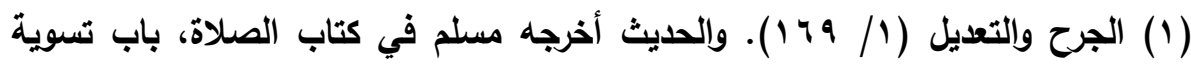

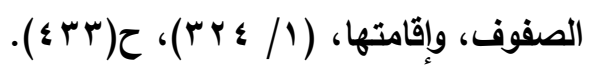

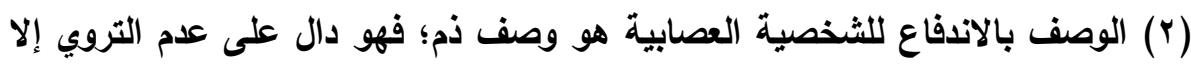
أن اندفاع قتادة في هذا الباب كان من أبواب الخير؛ فقد اندفع إلى طاعة من أجل الطاعات.

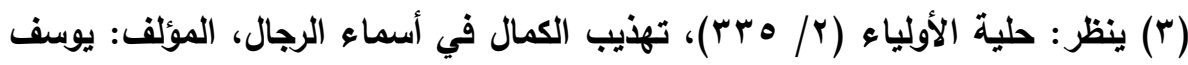

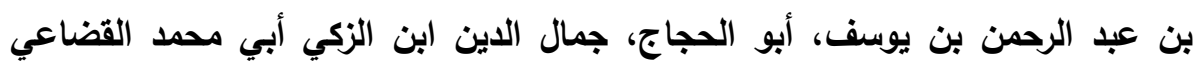

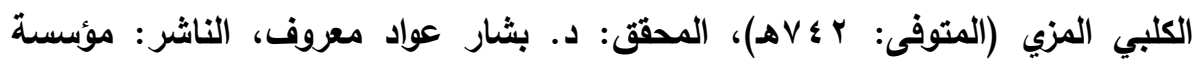

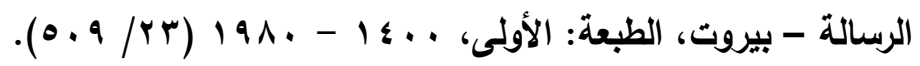


وعن قتادة قال: 》ما من القرآن آية إلا قد سمعتُ فيها شيئًا (1)، وقد بالغ في هذه الدرجة حتى قال مطر الورلق: "كان قتادة عبد العلم(ץ)، وكان -

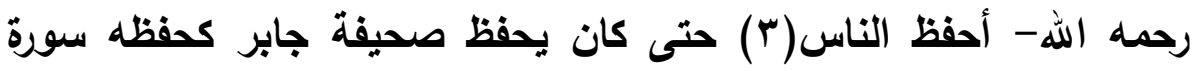

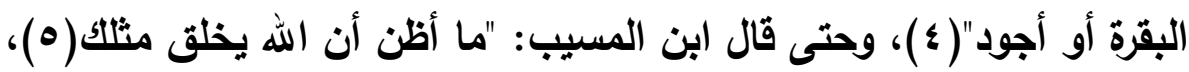

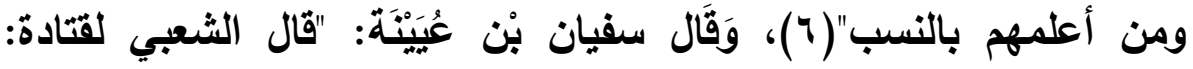

(1) ينظر: مسند ابن الجعد، علي بن الجَعْد بن عبيد الجَهْهَري البذادي (المتوفى:

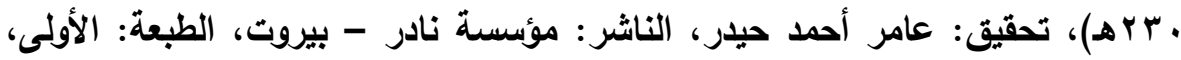

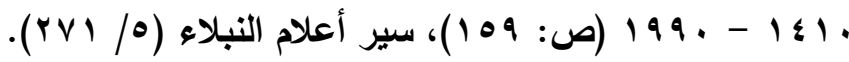

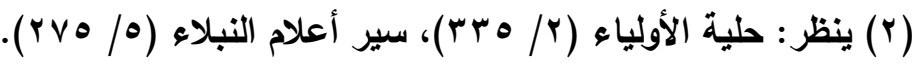

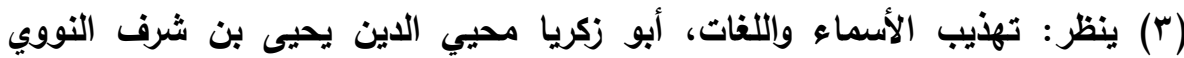

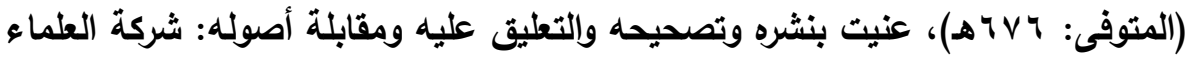

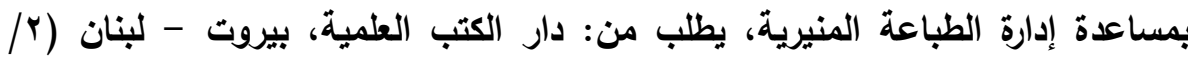

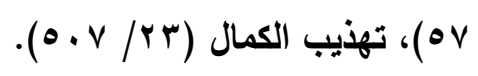

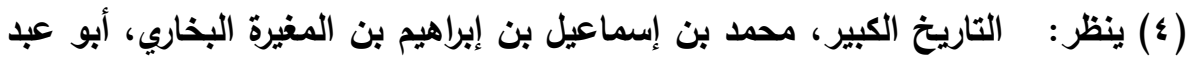

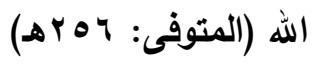
الطبعة: دائرة المعارف العثمانية، حيدر آباد - الاكن، طبع تحت مراقبة: محمد عبد المعيد

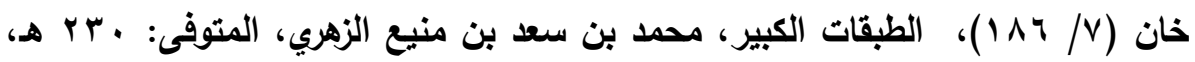

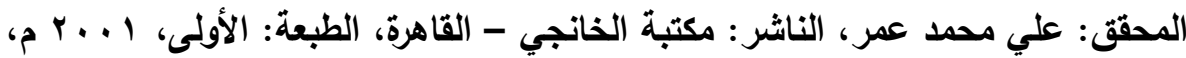

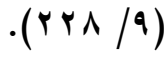

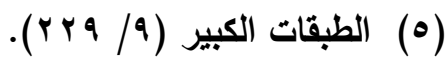

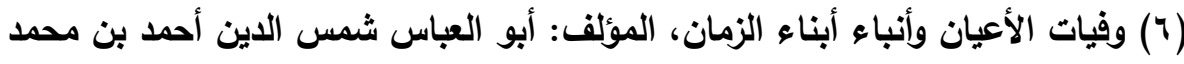

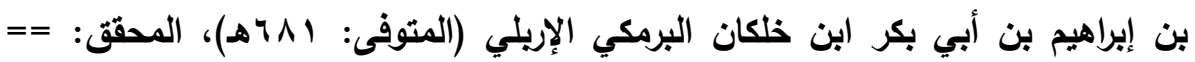


حاطب ليل. قال سفيان: قال لي عبد الكريم الجزري: تدري ما حاطب ليل؟

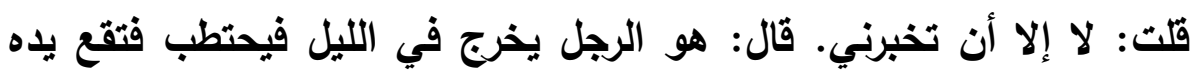

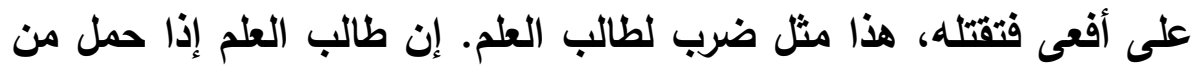

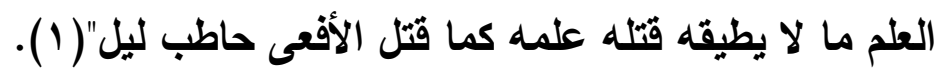

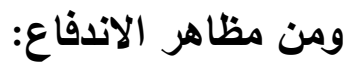
اندفاعه إلى الطعام؛ فعن الوزير بن عمران، قال: "كان قتادة إذا دعي إلى إلى

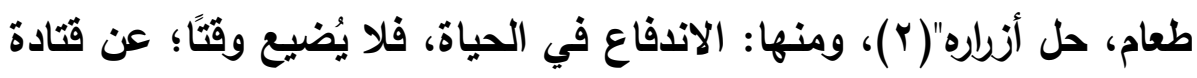

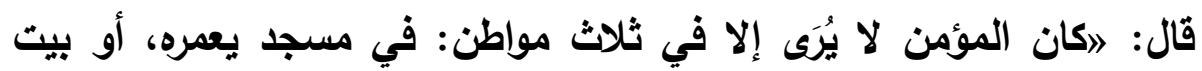

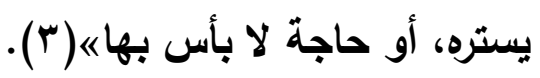
وصفه أبو نعيم فقال: "قتادة بن دعامة، ومنهم الحافظ الرغًّاب الواعظ الرهَّاب

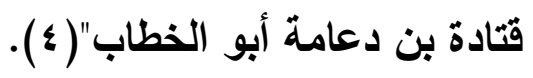

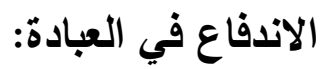

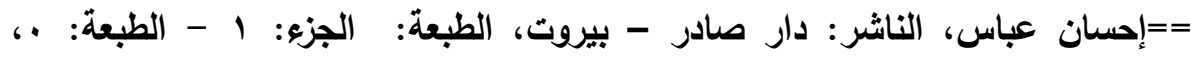

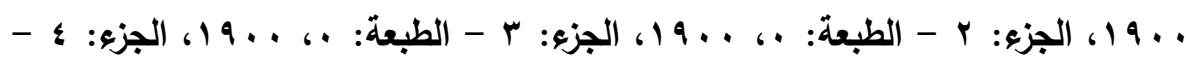

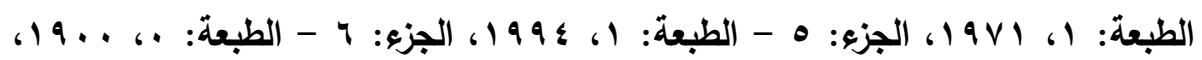

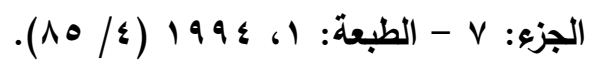

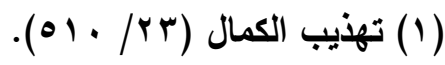

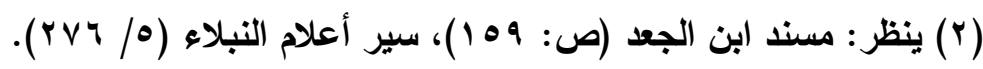

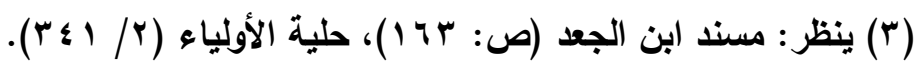

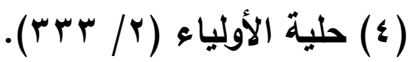


عن قتادة، أنه 》كان يختم القرآن في كل سبع ليال مرة، فإذا جاء رمضان

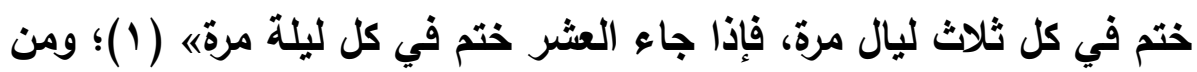

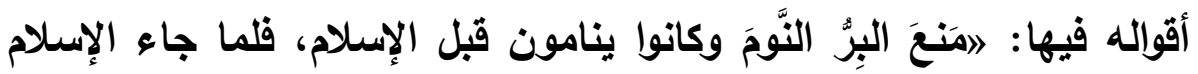

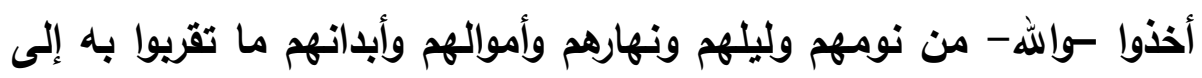
ريهم)(r) (1)

وأما العدائية مع الناس أحيانًا والتتي يمثلها حِدَّةُ رُدوده، ما قاله عفان: "أهدى

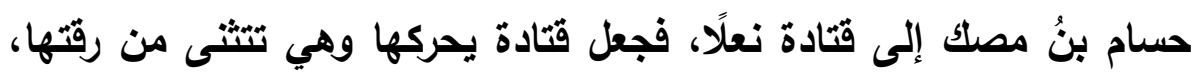
وقال: إنك لتعرف سخف الرجل في هديته"(ץ).

وعن حفص، عن قائد لقتادة، قال: "قتت قتادة عشرين سنة، وكان يبضض

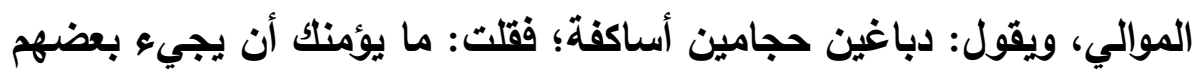

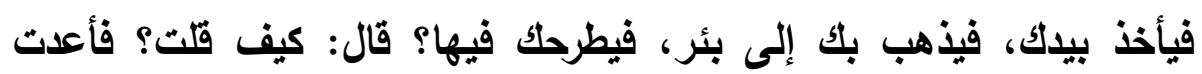
عليه، فقال: لا قدتني بعدها"( ؛ ). وذُكِكر يحيى بن أبي كثير عند قتادة، فقال: "متى كان العلم في

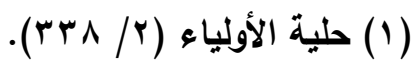

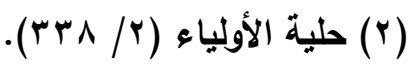

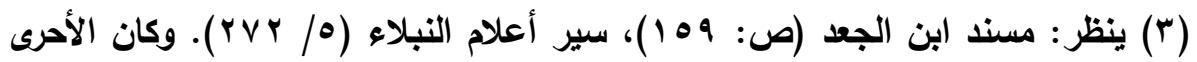
به -رحمه الله- أن يشكر الرجل؛ فيكفيه أنه أهدى. ألهي.

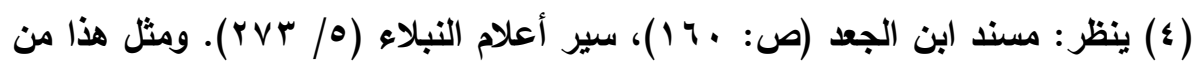
سمات العصابية، وليس المؤمن بالطعان. جلة كلية اصول الدين والدعوة / العدد السابع و الثلاثتون 9 ا ـ بم ـ الجزء الاول 
السماكين!!"(1)، وأما قَلقُه؛ فقد كان قتادة إذا سمع الحديث يختطقه اختطافا، يأخذه العويل والزويل(Y)، حتى يحفظه(ب)؛ بل يبدو أن القلق والغضب كان يؤدي به إلى الصداع ــلعله من ارتفاع الضغط- كما هي حال العُصابيين، حتى ابتكر وقاية للصداع؛ وعن سعيد بن أبي عروية، عن قتادة، قال: "دَهْنُ الحاجبيْنِ أمان من الصداع"(ع) . مظاهر غضبه في التحديث: وهذا يظهر في أنه لم يكن يُحب تكرير الحديث؛ عن قتادة، قال: "تكرير الحديث في المجلس يذهب نوره، وما قلت لأحد قط: أعد عليَّ"(•)، وعن قتادة، قال: "إعادة الحديث أشد من ثقل الصخر. ويقول: الكلام يشبع منه كما يشبع من الطعام"(").

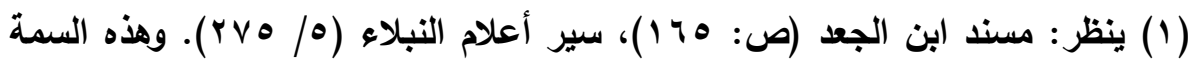

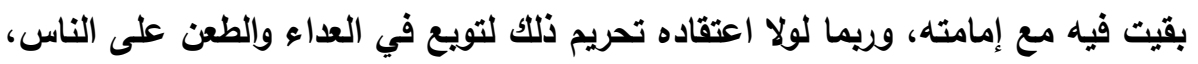
والله أعلم. (Y) يقال: أخذه الزويل والعويل لأمر ما؛ أب أخذه البكاء والحركة والقلق. ينظر : لسان

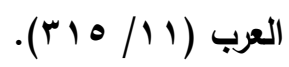

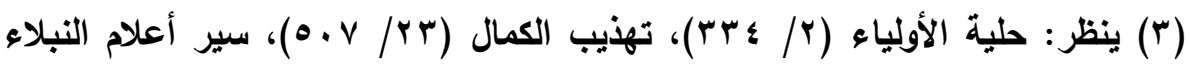
(rVr/0)

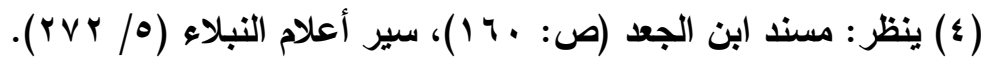

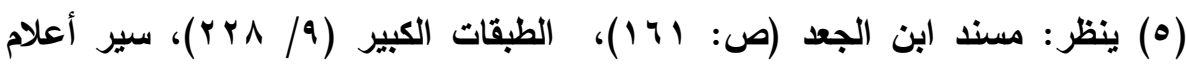

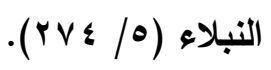

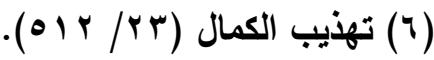


ومن مظاهر غضبه عمومًا، ولكن ضبطه بالشرع: عن مَعْمر، قال: "صك رجل ابنًا لقتادة؛ فاستعدى عليه عند بلال بن أبي بردة، فلم يلتقت إليه، فشكاه إلى القسري، فكتب إليه: إنك لم تتصف أبا الخطاب؛ فدعاه ودعا وجوه أهل البصرة يتشفعون إليه فأبى أن يشفعهم؛ فقال له: صُكَّه كما صكَّنَ فقال لابنه: ايا بني إحسر عن ذراعيك، وارفع يديك

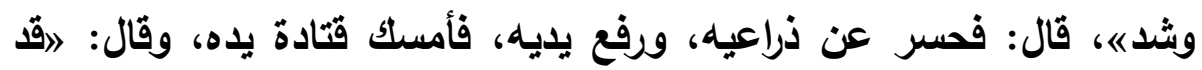
وهبناه لله؛ فإنه كان يقال: لا عفو إلا بعد قدرة" "( )، ولقتادة مواعظ كثيرة

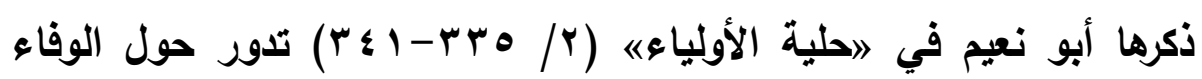
بعه الله والخوف منه، ومجاهدة النفس على طاعته، وهي تُعطي صورة عن سبب اندفاع هذا الإمام؛ فاندفاعه لم يكن لآفة نفسية، وإنما سكن قلبه من الخوف من الله ما حرّك به هذه النفس؛ فصارت في قمة الاندفاع إلى الخير(Y)؛ فمن هذه المواعظ: عن قتادة قال: "عليكم بالوفاء بالعهد، ولا تنقضوا هذه المواثيق؛ فإن الله قد نهى عن ذلك، وقدم فيه أشد التقدمة،

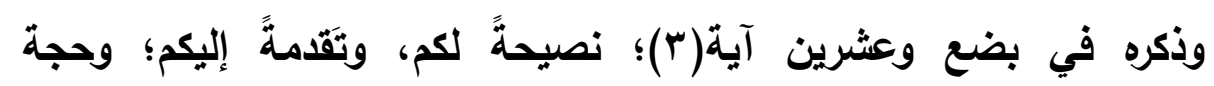

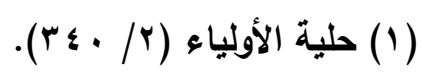

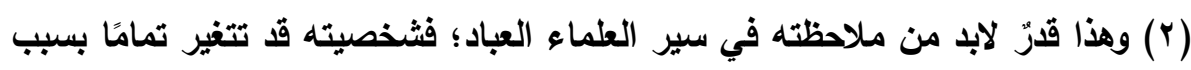

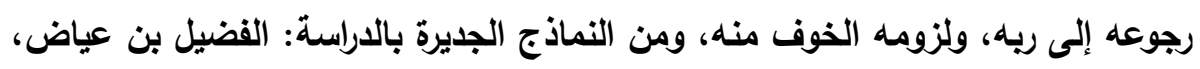

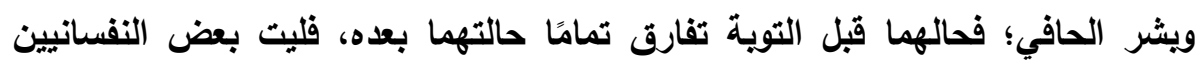
يدرس ذلك. وقا أشرنا إلى ذلك باختصار في المقدمة.

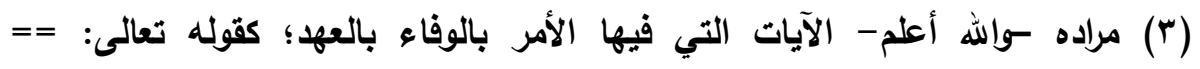


عليكم"( (1)؛ ومنها: عن قرة بن خالد، قال: „كان هجير قتادة إذا مر الحديث: ألا إلى الله تصير الأمور)(ب) (؟).

\section{$\sin \Delta \cos$}

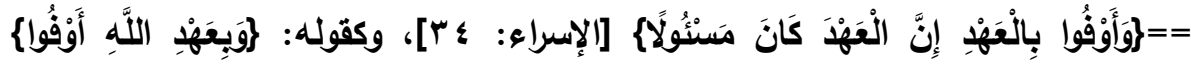

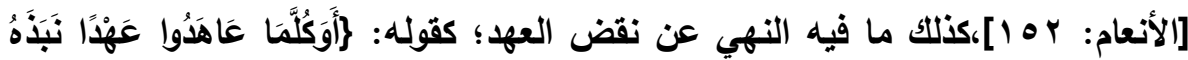

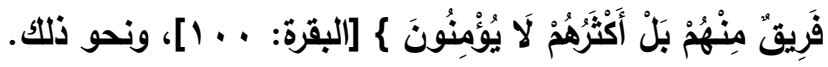

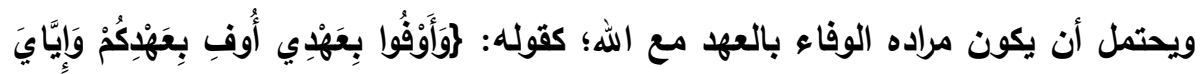

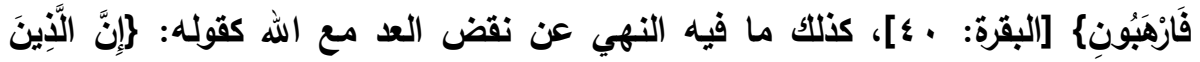

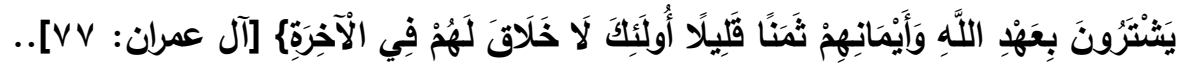

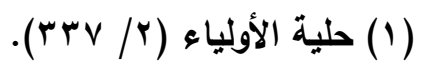

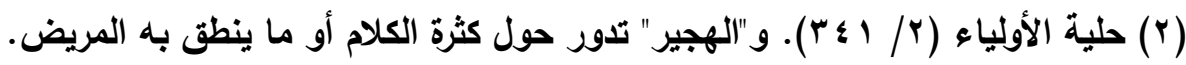

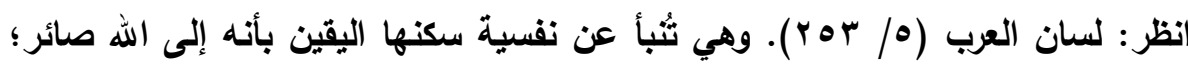

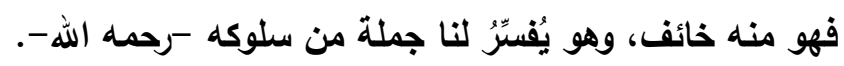

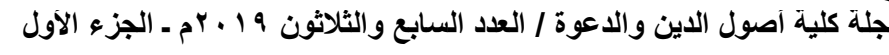




\section{البمش الثاني

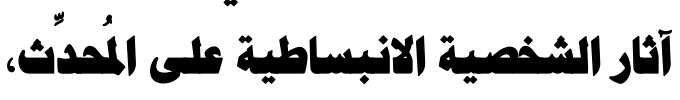 (سمة البمث عن الاستثارة أو الإفراب) أنموذجاً}

قدم البحث في التعريف بالعوامل الكبرى الخمسة: الانبساطية، ويُقابلها: الانطوائية.

وقدمنا أن أوجه الشخصية الانبساطية الستة هي: الدفء، الألفة، والحزم، والنشاط، وطلب الإثارة، والعواطف الإيجابية، ونتناول هنا سمة تُعبِّر عن فئه الشخصية الانبساطية وهي "البحث عن الاستثارة"، ويُسميه المُحَدِّثن:

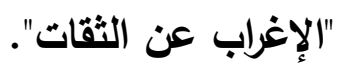

\section{ه أولاً: تعربف الإفراب عن الثقات:}

الإغراب لغة: الإتيان بأمر غريب؛ يقال: وأغربَ الرَّجل: جاء بشيء غريب. وأغرب عليه... الأصمعي: أغرب الرجل في منطقه إذا لم يبق شيئًا إلا تكلم به...أغرب الرجل إغرابا إذا جاء بأمر غريب" (1)، والمعنى الاصطلاحي قريب من اللُّوي؛ فإذا انفرد الرجل عنهم بالحديث يسمى غريبًا (؟)؛ فالإغراب

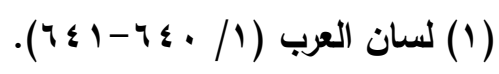

(r) أطراف الغرائب والأفراد من حديث رسول الله -صلى الله عليه وسلم- للإمام الارقطني، أبو الفضل محمد بن طاهر بن علي بن أحمد المقدي الثيباني، المعروف

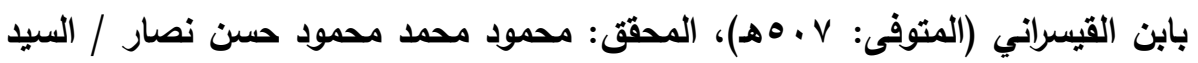

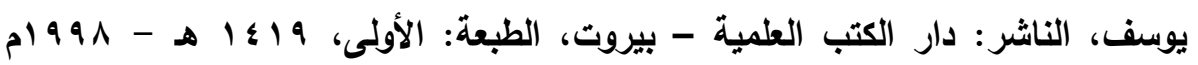
.$(\circ \mu / 1)$ 
هو أن يروي الراوي روايات غريبة لم يروها الثقات(1)، وقد تفطن العلامة

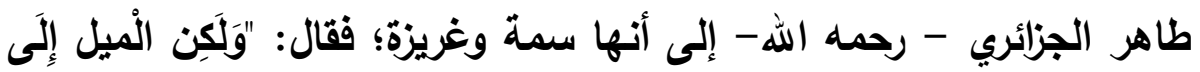

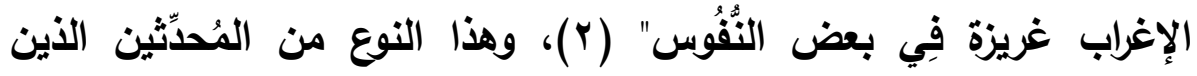

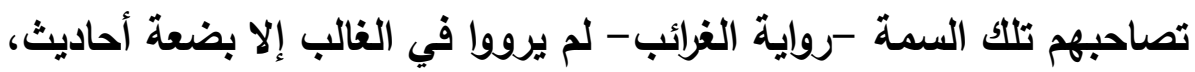
أغريوا بأكثرها، وكأنهم بذلك يريدون التميز والتفرد وسط الأقَران أو تكثير

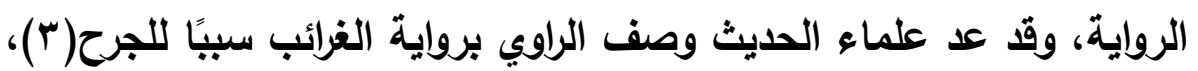

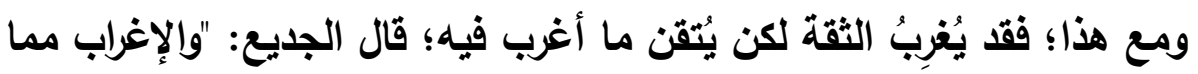
تميل إليه النفوس بطبعها، لكن مَن عُرفوا بالإتقان كانوا يتقون الإغراب إلا

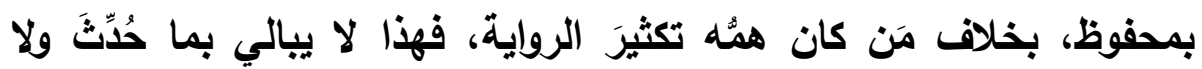

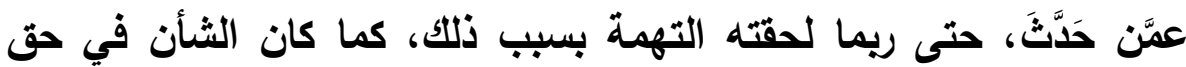

تحرير علوم الحديث، عبد الله بن يوسف الجديع، الناشر: مؤسسة الريان للطباعة

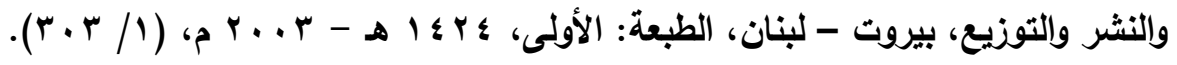

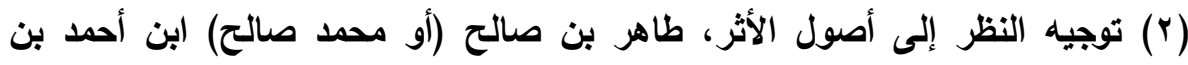

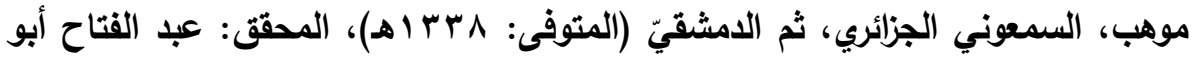

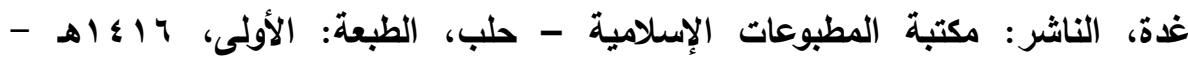

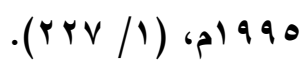

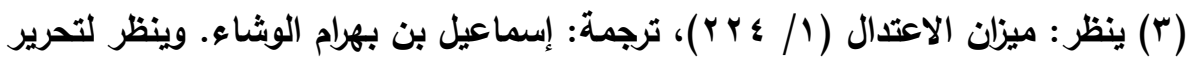

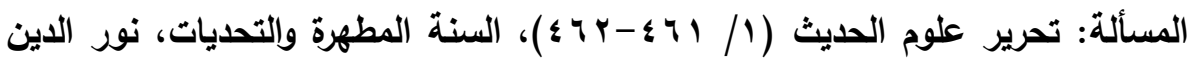

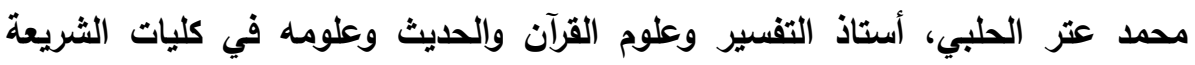

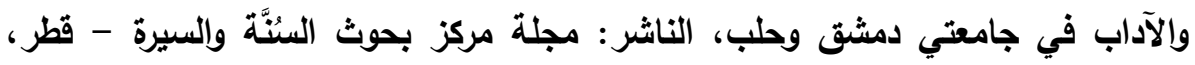

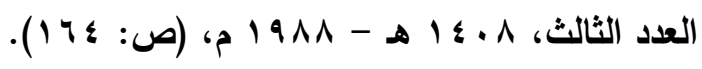


(الهيثم بن عدي)، و(محمد بن عمر الواقدي) وشبههما. كما قال أبو يوسف القاضي: "من تتبع غريب الدديث كُنبّب"( )(ץ). وعن عمرو بن خالد قال: "سمعت زهير بن معاوية، يقول لعيسى بن يونس:

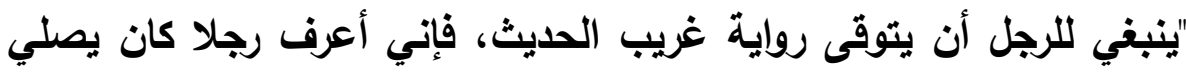

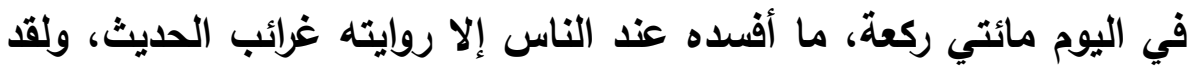

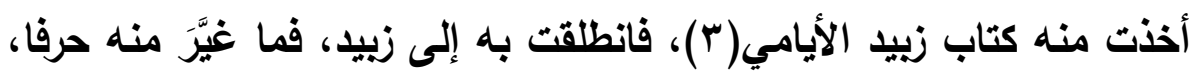

(1) أخرجه الرامهرمزي في المحدث الفاصل بين الزاوي والواعي، المؤلف: أبو محمد

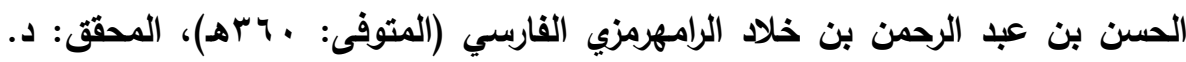

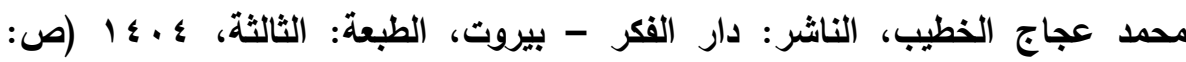

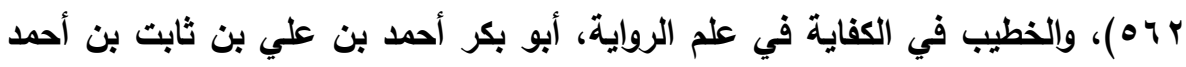

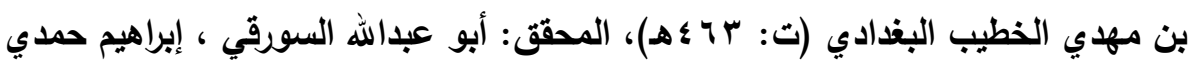

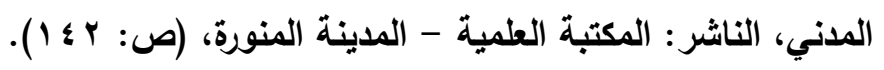

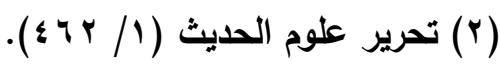

(ץ) زبيد الأيامي، هو : زبيد بن الحارث اليامي الكوفي، الحافظ، أحد الأعلام.

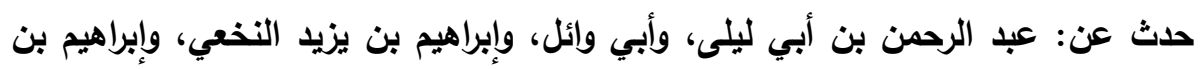
سويد النغعي، وطائفة. حدث عنه: جرير بن حازم، وشعبة، ومحمد بن طلحة، وسفيان الثوري، وشريك، وآخرون. قال شعبة: ما رأيت رجلا خيرا من زيبد.

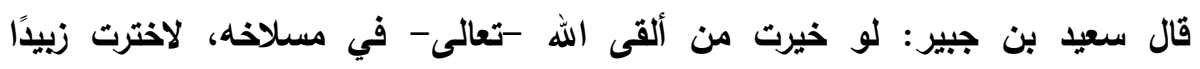
اليامي.قيل: مات سنة اثثتين وعشرين ومائة.

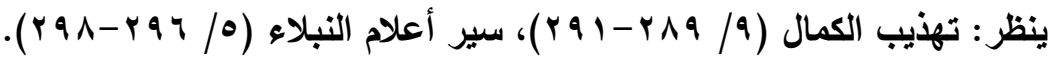


إلا أنه بلغني أنه كان يقول في أحاديث سمعها مني: حدثي عبد الرحمن بن

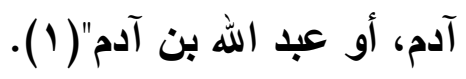

ه ثانياً: العلماء الذين اتصفوا بسمة الإغراب عن الثقات:

وممن اتصف بهذه الصفة من العلماء:

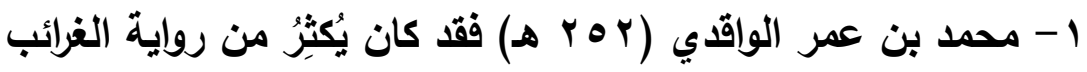

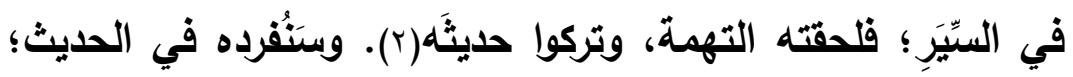

لظهور هذه السمة فيه.

r- عبد الواحد بن سليمان، كان خادما لابن عون، وكان يغرب عنه

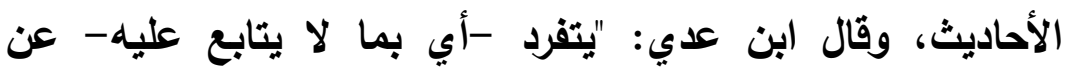

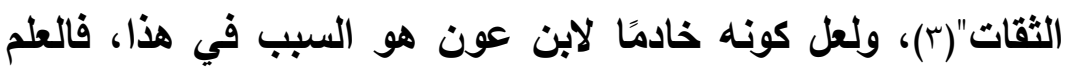

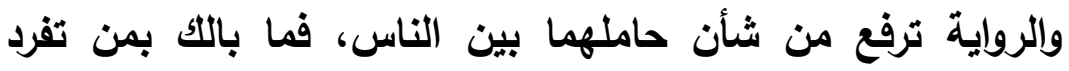

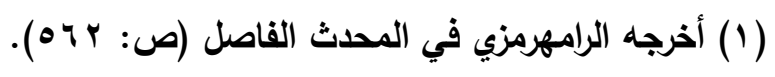

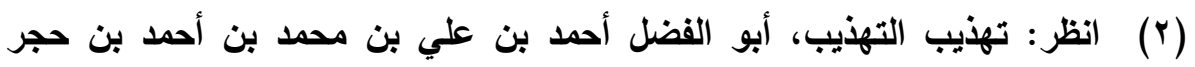

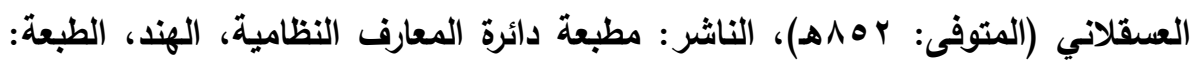

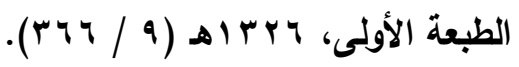

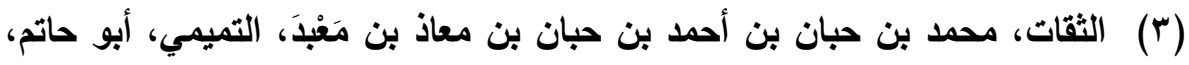

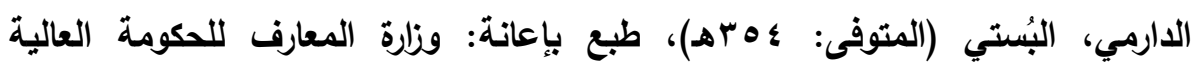

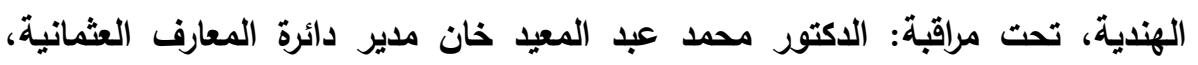

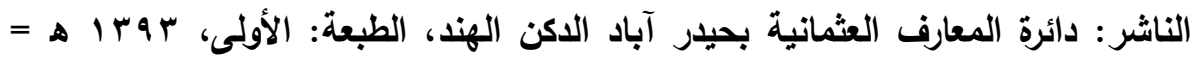

$$
\text { .(VA/T) 19VT }
$$

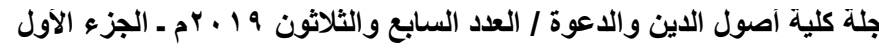


ببعض الروايات عن شيخه ولم يروها غيره، فلعل مثل هذا باعث له

$$
\text { لتلإغراب والتفرد. }
$$

ومن الثقات: الإمام مالك، فله فرائد وغرائب، أفردها ابن المظفر (المتوفى: عه بـVq

$$
\text { عنd-1) (1) (1) (1) }
$$

\section{" ثالثاً: أثر سمة الإغراب على الواقدي :}

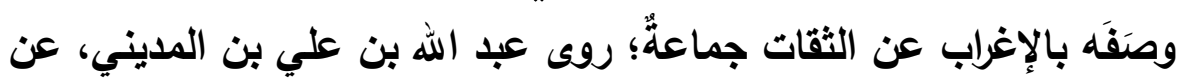

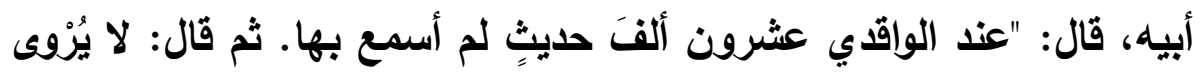

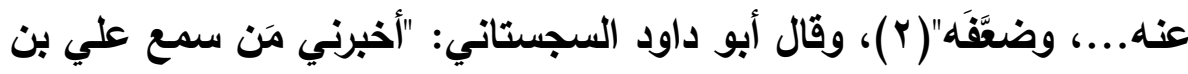

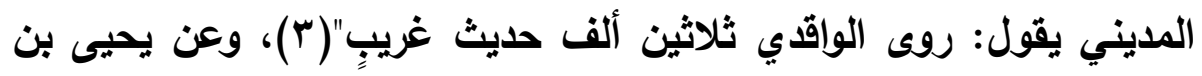

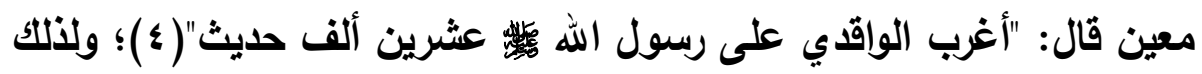

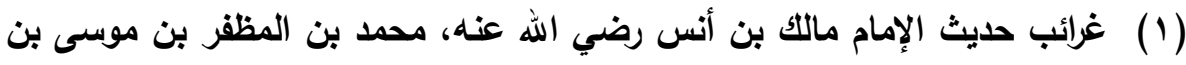
عيسى، أبو الحسين البزاز البذادي، دار السلف، الرياض - السعودية، تحقيق: أبي عبد البدان

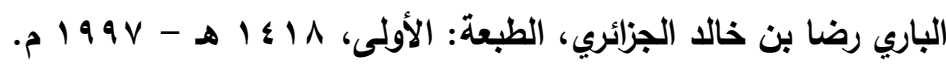

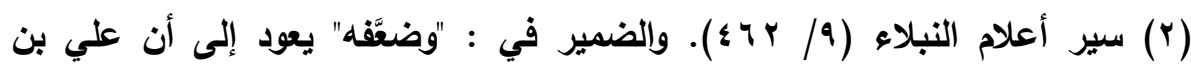

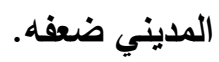

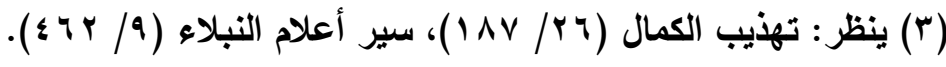

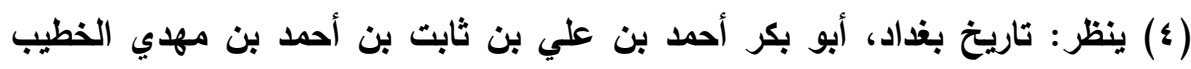

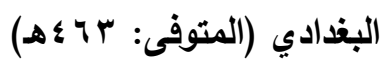

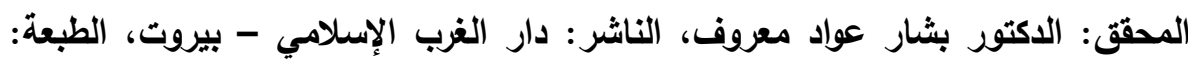

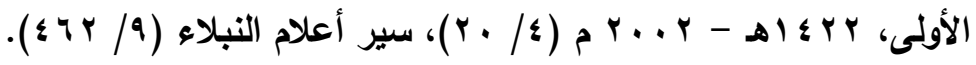


تركه يحيى؛ فقال: "ليس الواقدي بشيء"( ).

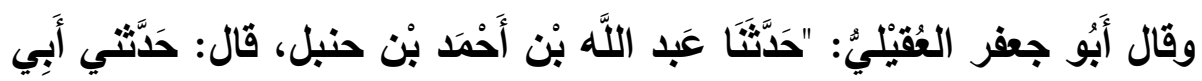
قال: سمعت وكيعا يقول لأبي عَبْْ الرَّحْمَنِ، يعني الضرير، وحدث بحديث زمعة في غسل الحصا للجمار، فقال: لو كنت عند الواقدي لحدثك فيه بكذا وكذا، يعني كذا وكذا"(ץ)، وهذا الإغراب جعل طائفة من أهل العلم يتهمونه

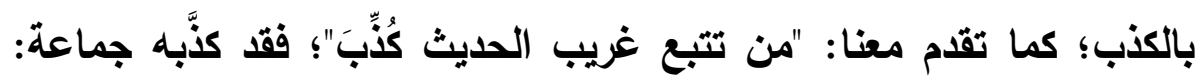

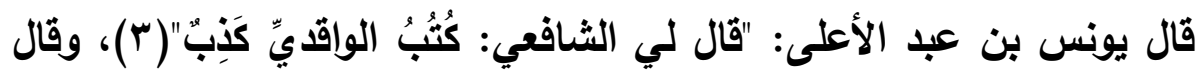
أحمد بن حنبل: "الواقدي كذَّابٌ"(ع)، وقال إسحاق: "هو عندي ممن يضع الحديث -يعني: الواقدي-(0)، إلا أن المُعتمد عند أهل العلم أنه لا يتعمد الكذب؛ قال الأهبي: "وقد تقرر أن الواقدي ضعيف، يحتاج إليه في الغزوات والتاريخ، ونورد آثاره من غير احتجاج، أما في الفرائض، فلا ينبغي أن

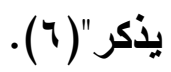
رابعاً: نماذه تدل على اتهافه بسمة (الإفراب عن الثقات): قال أحمد بن أبي شريح، قال: "سمعت محمد بن إدريس الشافعي، يقول:

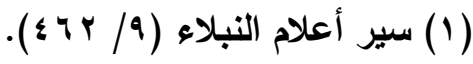

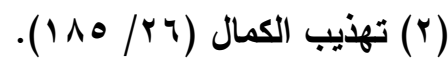

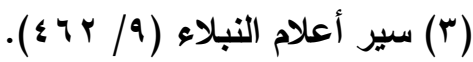

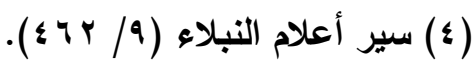

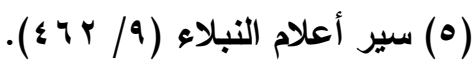

$$
\begin{aligned}
& \text { (7) سير أعلام النبلاء (9/9 9 ؟ ؟). }
\end{aligned}
$$


الواقدي وصل حديثين، يعني لا يوصلان"( ()، قال لي فوران: "رآني الواقدي

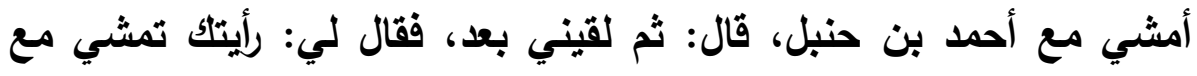

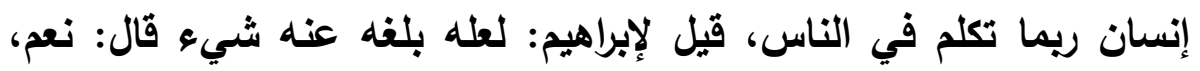

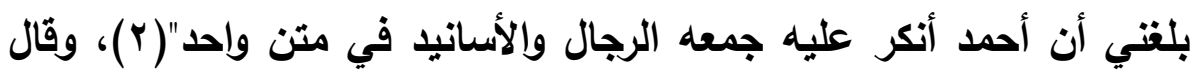

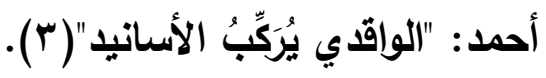

وقال يحيى بن معين :"الواقدي يحدث عن عاتكة ابنة عبد المطلب، وعن

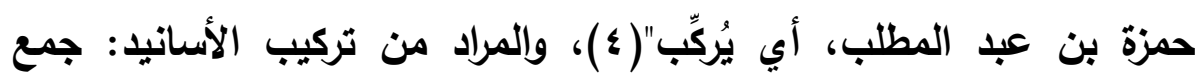

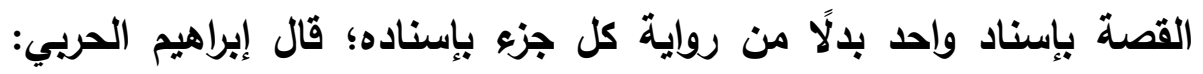

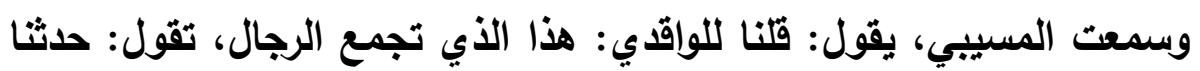
فلان وفلان وجئت بمتن واحد، لو حدثتا بحليث كل رجل على حِة، قال:

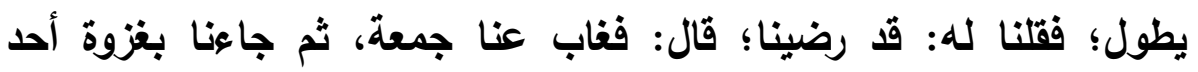

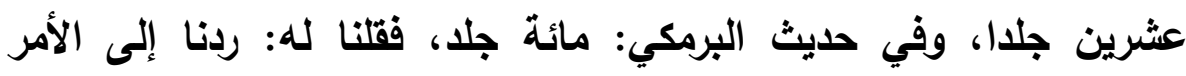

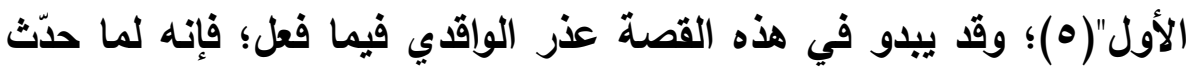

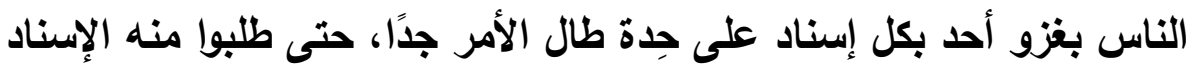

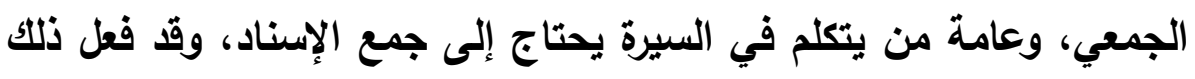

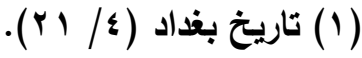

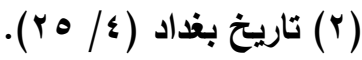

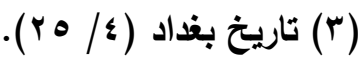

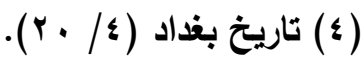

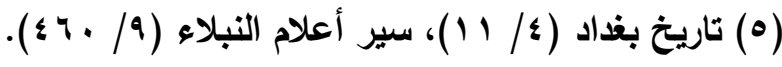


الزهري في حديث الإفك إلا أنه جمع رواية الثقات بينما الواقدي يجمع عن

$$
\text { الثقات وغيرهم (1). }
$$

\section{ـ خامسأ: آثار سمة (الإفراب عن الثقات) على آراء الواقدي المديثية:}

يتبين مما سبق أن إغراب الواقدي تسبب في جرح المُحدِّثين لله، فلم يعتمدوا

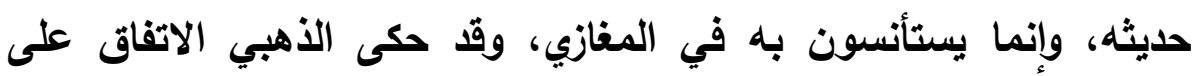

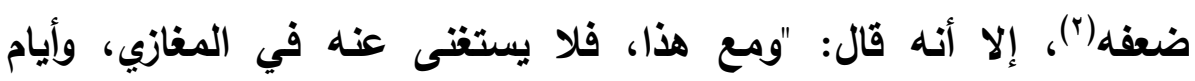

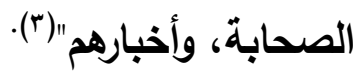

\section{ه سادساً: مدى وجود هذه الانبساطية في هياة الواقدي عموماً:}

بتأملنا سيرة الواقدي، وجدنا آثار الانبساطيةِ عمومًا ماثلةً في حياته، ولهها

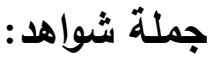

فهو رجلٌ ذو عواطف إيجابية وانبساطية مجتمعية، ولم يكن فيه الثدة التي

(1) ينظر في هذه المسألة المهمة: مصادر السيرة النبوية ومقدمة في تدوين السيرة، المؤلف: محمد يسري سلامة، تقديم: د. بثار عواد معروف الناشر: دار الجبرتي - دار

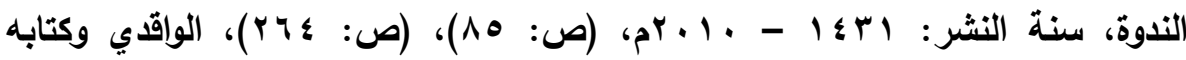
المغازي منهجه ومصادره، الدكتور عبد العزيز بن سليمان بن ناصر السلومي، رسالة، دكتوراه مقدمة إلى الجامعة الإسلامية بالمدينة المنورة، الناشر : مكتبة الملك فهد الوطنية،

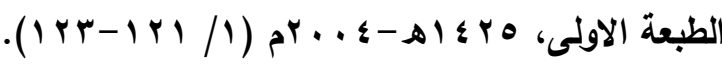

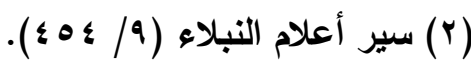

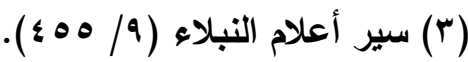


كانت في أهل الحديث في زمانه(') بل كان ودودًا وصولًا؛ قال وكيع: "حَبَّنَيَي

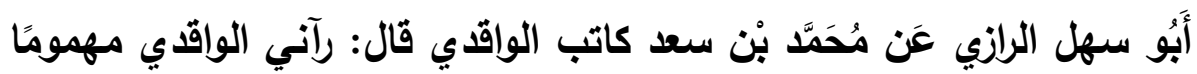

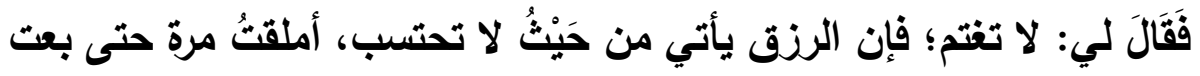

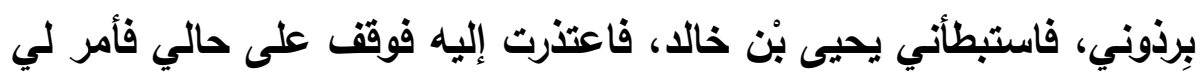

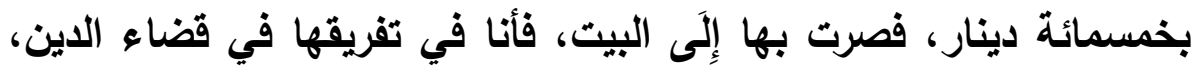

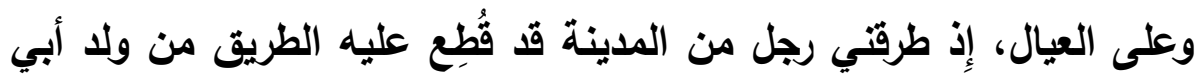

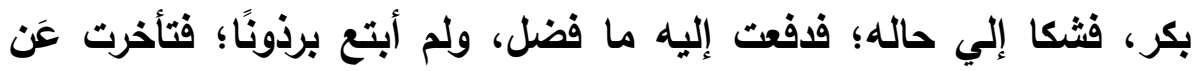

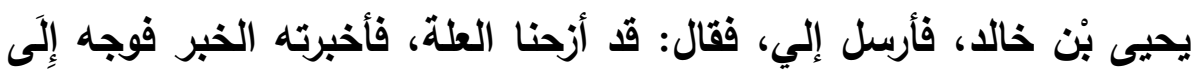

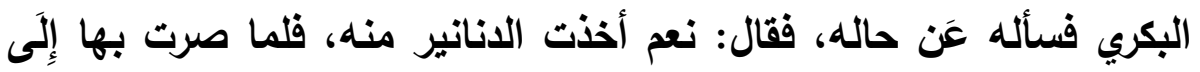

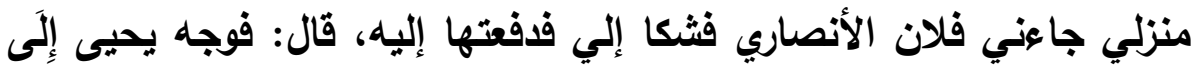
الأنصاري فأخبره الخبر، فعجب يحيى من الكرم، ثم أمر لي بألف دينار،

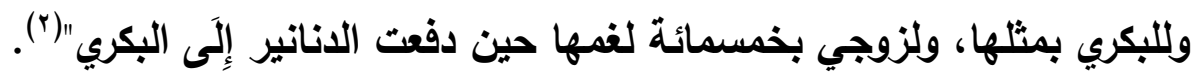
وقد أدرك الخليفة العبَّاسي المأمون هذه الصفة؛ فكان المأمون يكرم جانبه

(1) قدمنا الكلام على غضب قتادة، ويأتي الكلام على تغنت يحيى القطان، وسواهم خلق كثير.

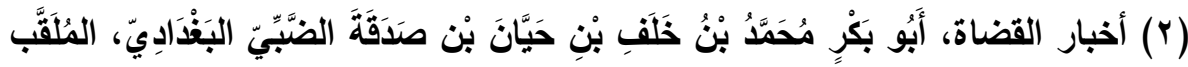

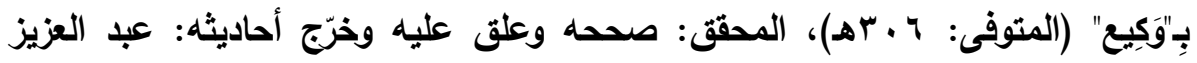

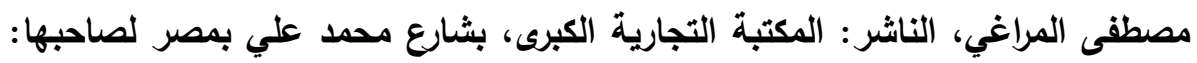

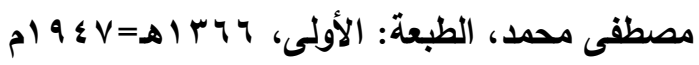

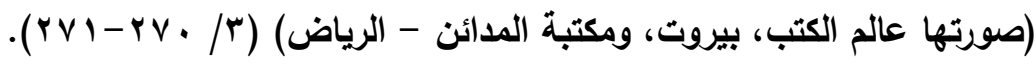


ويبالغ في رعايته، وكتب إليه مرة يشكو ضائقة لحقته وركبه بسببها دَيْن، وعين مقاره في قصته، فوقع المأمون فيها بخطه: "فيك خلتان سخاء وحياء، فالسخاء أطلق يايك بتبذير ما ملكت، وإلحياء حملك أن ذكرت لنا بعض دَيْتك، وقد أمرنا للك بضِعف ما سألت، وإن كنَّا قصرنا عن بلوغ حاجتك فبجنايتك على نفسك، وإن كنا بلغنا بغيتك فزد في بسطة يدك، فإن خزائن الله مفتوحة ويده بالخير مبسوطة، وأنت حدثتي حين كنت على قضاء الرشيا أن النبي

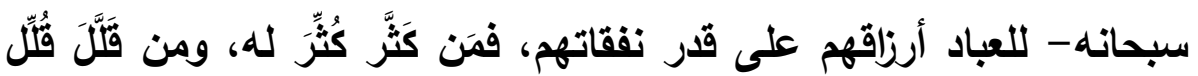
عليه، قال الواقدي: وكنت نسيت الحديث، فكانت مذاكرته إياي أعجب إليَّ مِن صِلته" (1)

وكان من صفته الجود، والإيثار(r) وهما من جملة العواطف التبيلة الدالة على الانبساطية: وقال الواقدي: "كان لي صديقان أحدهما هاشمي، وكنا كنفس واحدة، فنالتني ضائقة شديدة، وحضر العيد فقالت امرأتي: أما نحن في أنفسنا فنصبر على البؤس والثدة، وأما صبيانتا هؤلاء فقد قطعوا قلبي رحمة لهم؛ لأنهم يرون صبيان الجيران قد تزينوا في عيدهم، وأصلحوا ثيابهم وهم على هذه الحال من الثياب الرثة، فلو احتلث في شيء تصرفه في كسوتهم، قال: فكتبت إلى صديث لي وهو الهاشمي أسأله التوسعة علي بما حضر، فوجه إلي كيسا مختوما ذكر أن فيه ألف درهم، فما استقر قراري حتى كتب

$$
\begin{aligned}
& \text { (1) وفيات الأعيان ( ( / 9 ؛ ب). }
\end{aligned}
$$

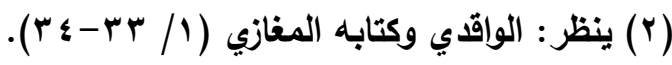


إلليَّ الصديق الآخر يشكو مثل ما شكوت إلى صاحبي الهاشمي، فوجهت إليه

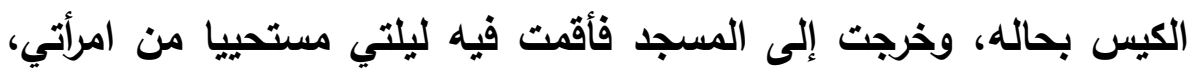

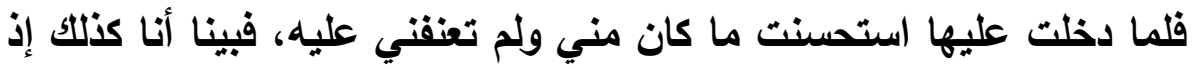
وافى صديقي الهاشمي ومعه الكيس كهيئته، فقال لي: اصدقني عما فعلته

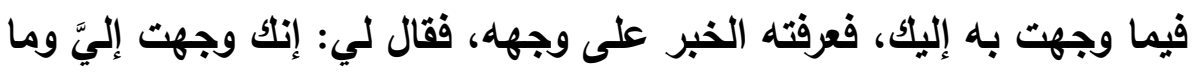
أملك على الأرض إلا ما بعثت به إليك، وكتبت إلى صديقه وجنا أسأله المواساة، فوجه كيسي بخاتمي، قال الواقدي: فتواسينا ألف درهم فيما بينتا، ثم إنا

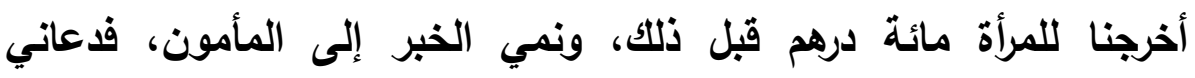

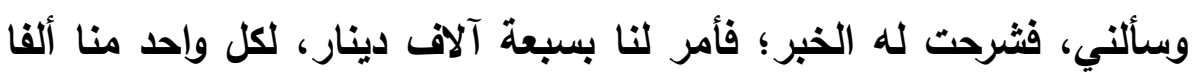
دينار ، وللمرأة ألف دينار"( (1). وقد بلغ به السعة في الجود والإيثار إلى أنه لم يبق له كفن؛ قال عباس الدوري: "مات الواقدي وهو على القضاء وليس له له كفن، فبعث المأمون

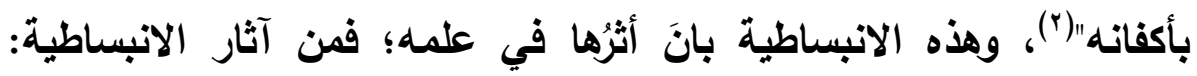

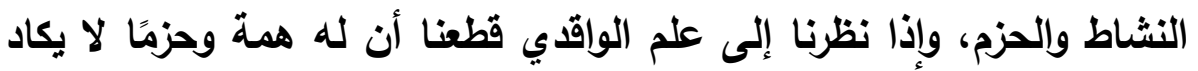

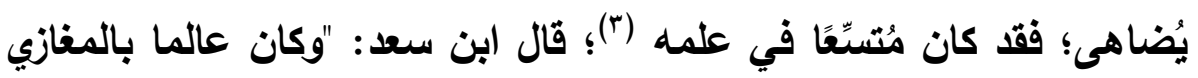

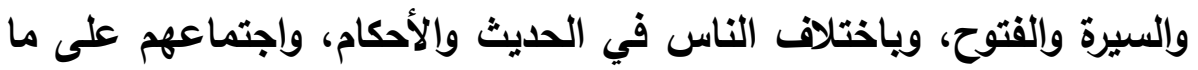

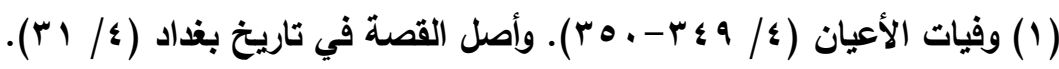

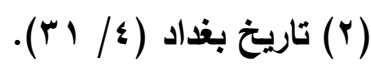

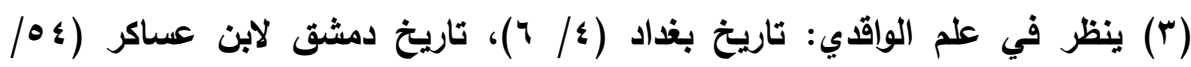

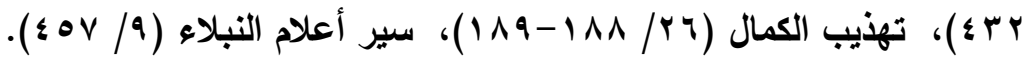
مجلة كلية اصول الاين والدعوة / العدد السابع والثلاثون 9 1. بام ـ الجزء الاول 
اجتمعوا عليه، وقد فسر ذلك في كتب استخرجها ووضعها وحدث بها"(1. وقال الأهبي: الواقدي، "المديني، القاضي، صاحب التصانيف والمغازي، العلامة، الإمام، أبو عبد الله، أحد أوعية العلم على ضعفه، المتفق عليه"(؟)، ومن شهرته وانبساطه للناس ما جاء عنه من قوله: "كاتت ألواحي تضيع، فأوتى بها من شهرتها بالمدينة. يقال: هذه ألواح ابن واقد"()، وقد كان كثير الكتب إلى الارجة لما انتقل الواقدي من جانب الغزبي، يقال: "إنه حمل كتبه على عشرين ومائة وقر"(؛)، ومع هذا؛ فكتبه أكثر من حفظه سوهو القائل-: "ما من أحد إلا وكتبه أكثر من حفظه، وحفظي أكثر من كتبي"(•). تتبه علماء الجرح والتعديل لهذه السمة في الواقدي: طالعنا نماذج من كلام أهل العلم في الواقدي، وكيف أنهم ضعفوه وتركوا حديثه؛ لأنه يجمع الأسانيد صحيحها إلى ضعيفها، وهو غير مرضي عند المُحدِّثن، إلا أنهم استأنسوا به في المغازي والسير، واعتمدوا عليه فيها؛ لإتقانه، وهذا من عدلهم سرحمه الله-. قال الأهبي ملخصًا حاله: "وقد تقرر أن الواقدي ضعيف، يُحتاج إليه في الغزوات والتاريخ، ونورد آثاره من غير احتجاج، أما في الفرائض، فلا ينبغي أن يُّكرَ، فهذه الكتب الستة، و(مسند

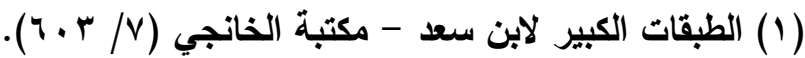

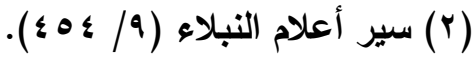

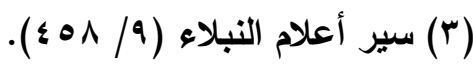

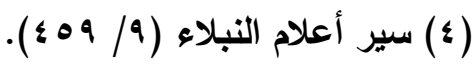

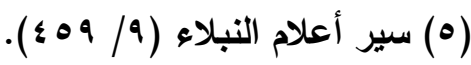


أحمد)، وعامة من جمع في الأحكام، نراهم يترخصون في إخراج أحاديث

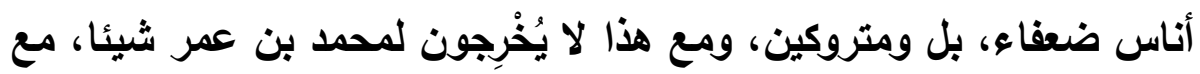
أن وزنه عندي أنه - مع ضعفه - يكتب حديثه ويروى؛ لأني لا أتهمه بالوضع، وقول من أهدره، فيه مجازفة من بعض الوجوه، كما أنه لا عبرة

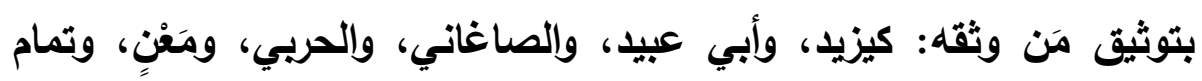
عشرة مُحدِّين، إذ قد انعقد الإجماع اليوم على أنه ليس بحجة، وأن حديثه

في عداد الواهي -رحمه الله (').

(1) سير أعلام النبلاء (9/9 9 ؛ ). 


\section{المبحث الثمالث

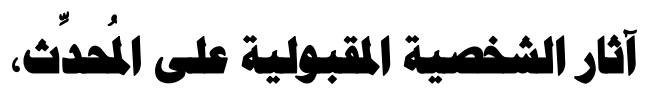 (الرحمة والعhف) أنموذجةًاً}

قدمنا أن للشخصية المقبولية (الطيبة=الوادعة) أوجهاً، منها: الثقة، الاستقامة، الإيثار، الانسجام، التواضع، التعاطف، فنتعرض لسمة: "الرحمة والعطف"، للنظر إلى أثرها في المُحدِّثنين.

ه أولأ: العلماد الذين التهفها بسمة الرهمة والعمف ونماذه دالة على ذلك:

وممن اتصف بهذه السمة من العلماء: عبد الله بن المبارك (')، ومن النماذج التي تلل على اتصافه بسمة (الرحمة والعطف) منها: "عن محمد بن علي بن الحسن بن شقيق سمعت أبي قال: كان ابن المبارك إذا كان وقت الحج اجتمع إليه إخوته مِن أهل مرو فيقولون: نصحبك يا أبا عبد الرحمن، فيقول لهم: هاتوا نفقاتكم فيأخذ نفقاتهم فيجعلها في صندوق ويققل عليها، ثم

(1) الإمام عبد الله بن المبارك من أعظم أهل الإسلام في عموم أبواب الدين، وترجمته

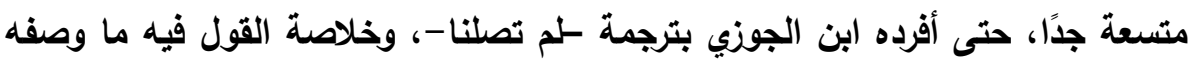
أبو نعيم؛ فقال في حلية الأولياء

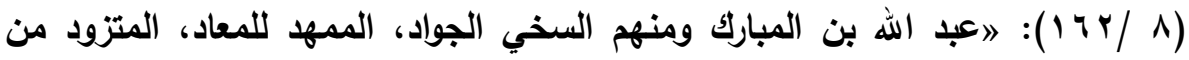

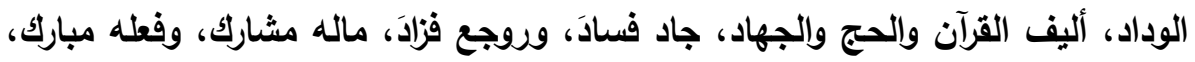
وقوله مبارك شاها نشاهی.اهـ. اله. 
يكتري لهم ويخرجهم من مرو إلى بغداد؛ فلا يزال ينقق عليهم ويطعهم أطيب

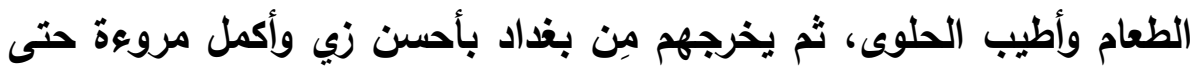

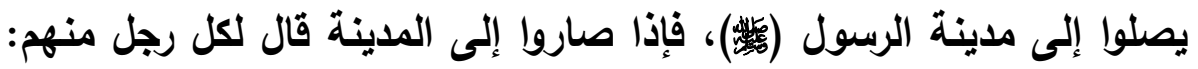
ما أمرك عيالك أن تثتري لهم من المدينة من طرفها؟ فيقول: كذا، ثم لثرل

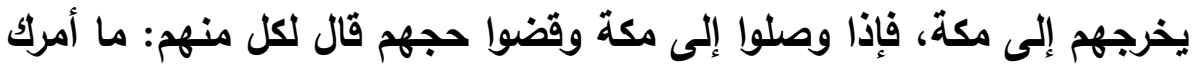

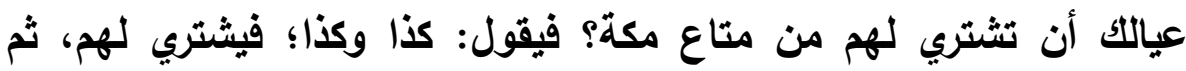
يخرجهم من مكة فلا يزال ينفق عليهم إلى أن يصيروا إلى مرو، فإذا صاروا إلى مرو جصص أبوابهم ودورهم، فإذا كان بعد ثُلاثة أيام صنع لهم وليمة إلهان

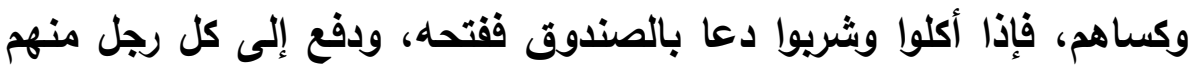

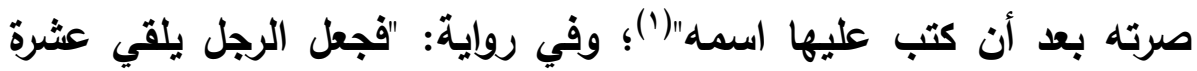

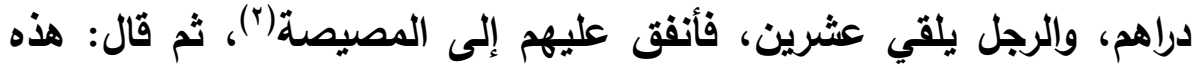

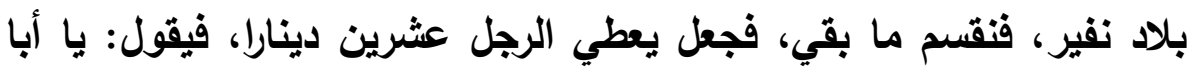

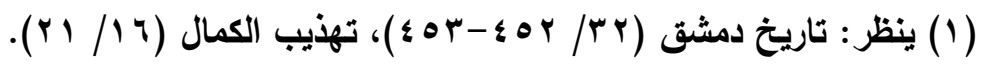

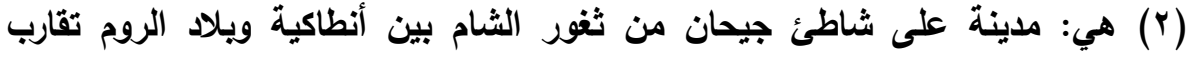

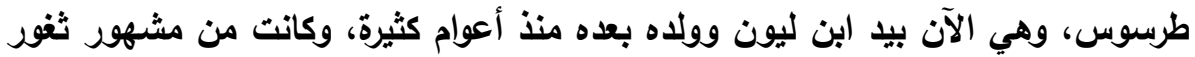

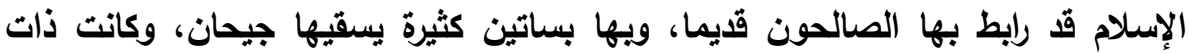

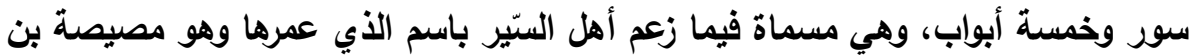

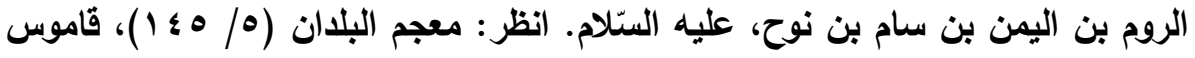

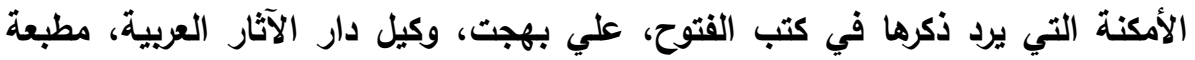

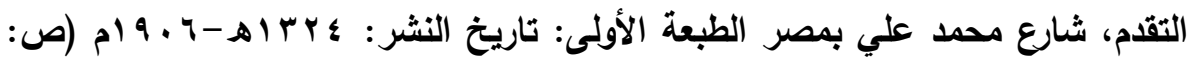


عبد الرحمن! إنما أعطيت عشرين درهما؛ فيقول: وما تنكر أن يبارك الله

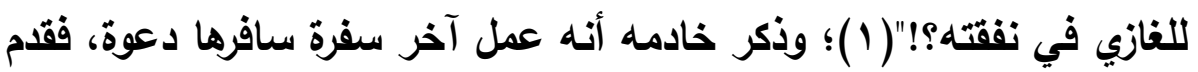

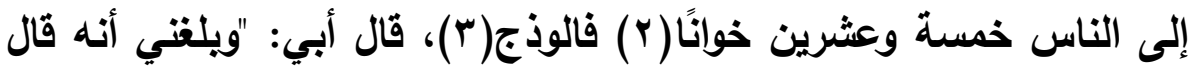

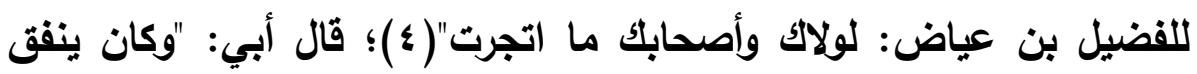

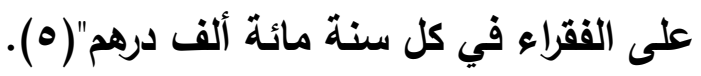

وعن سلمة بن سليمان قال: "جاء رجل إلى عبد الله بن المبارث، فسأله أن

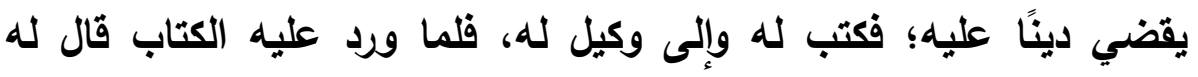

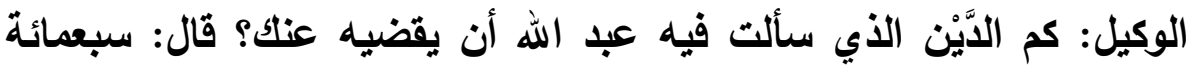

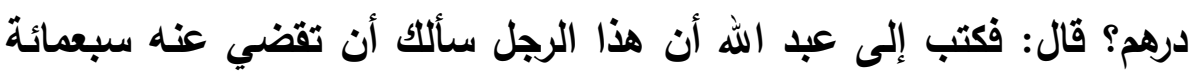

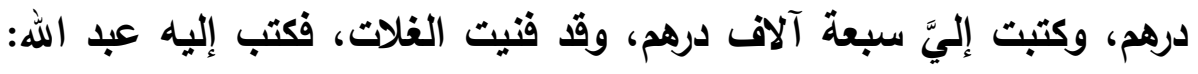

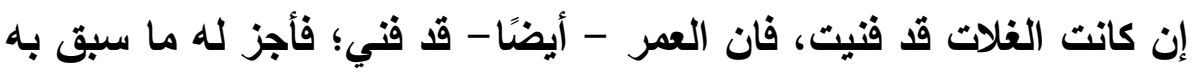

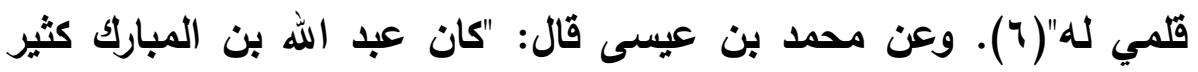

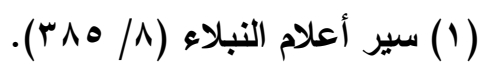

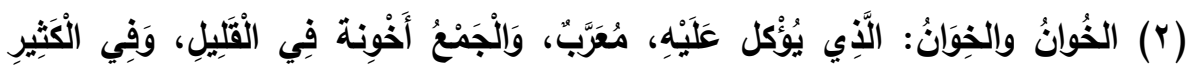

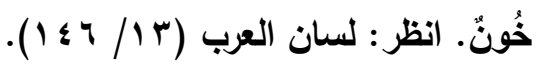

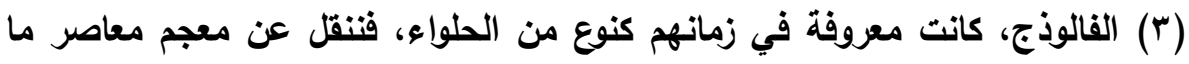

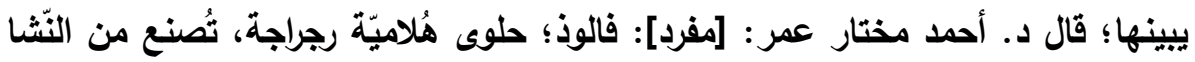

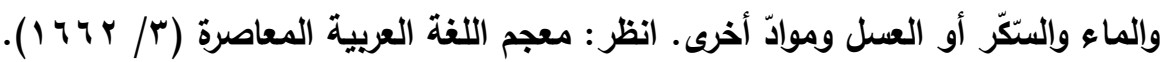

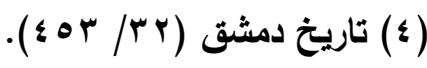

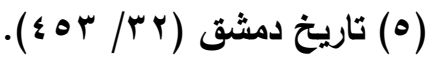

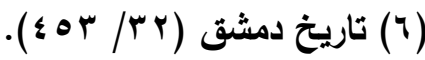


الاختلاف إلى طرسوس(1)، وكان ينزل الرقة في خان، فكان شاب يختلف

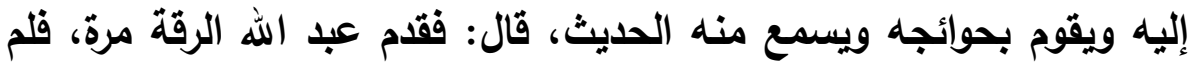
ير ذلك الثاب، وكان مستعجلًا؛ فخرج في النفير، فلما قفل من غزوته، ورجع إلى الرقة، سأل عن الثاب، قال : فقالوا: إنه محبوس لَدَيْنِ ركبه، قاله

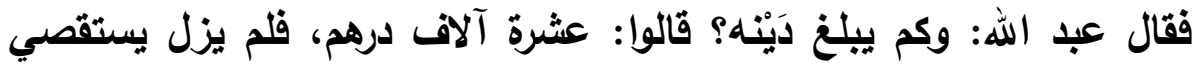

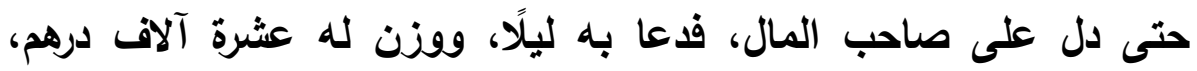

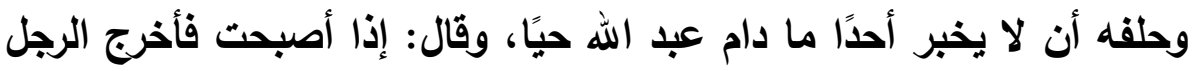
من الحبس، وأدلج عبد الله، فأخرج الفتى من الحبس، وقيل لله: عبد الله بن الها المبارك كان ها هنا، وكان يذكرك، وقد خرج؛ فئه الهرج الفتى في أثره، فلحقه

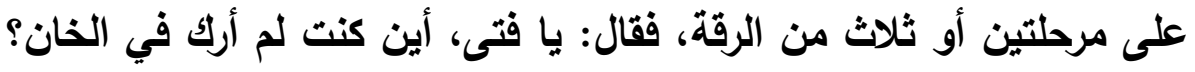

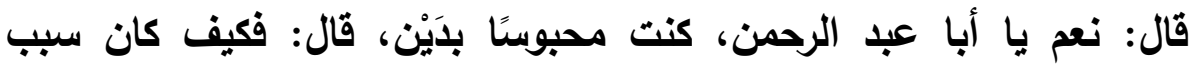

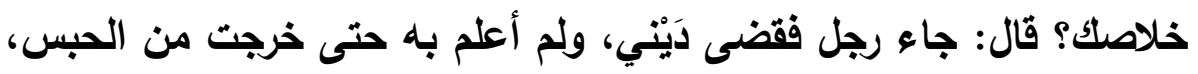

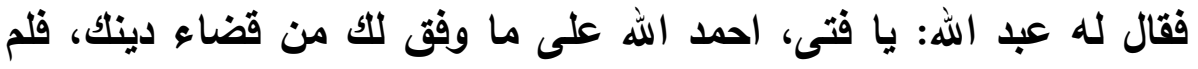

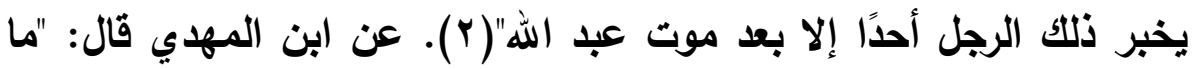

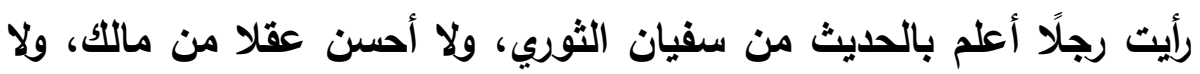

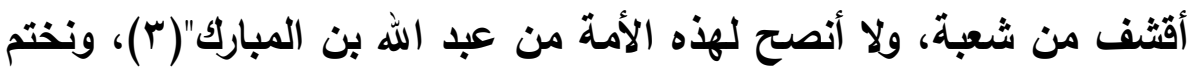

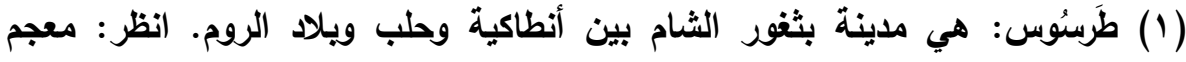

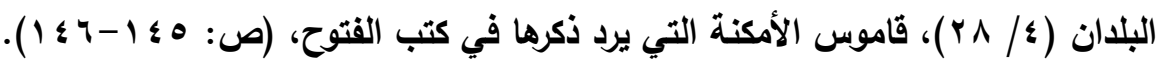

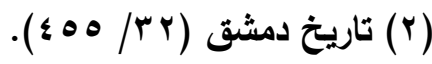

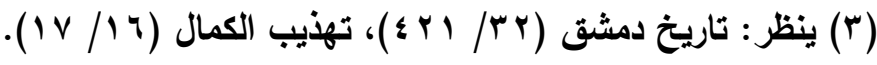
مجلة كلية اصول الدين والدعوة / العدد السابع والثلاثون 9 ا ـ بم ـ الجزء الاول 
بموقف يُبين رحمته بالناس في النصيحة؛ فعن ابن حميد، قال: "عطس رجل عند ابن المبارك، فقال له ابن المبارك: أيش يقول الرجل إذا عطس؟ قال: الحمد لله. فقال له: يرحمك الله"( ). (1).

\section{ثانياً: آثار سمة (الرهمة والعمف) على آرانه المديثية:}

قبل الثروع في بيان آثار هذه السمات في حياة ابن المبارك، نُشير إلى أنه

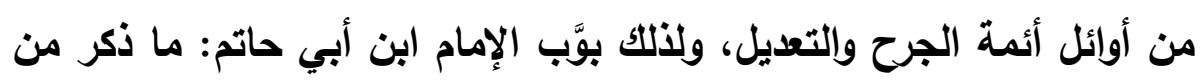

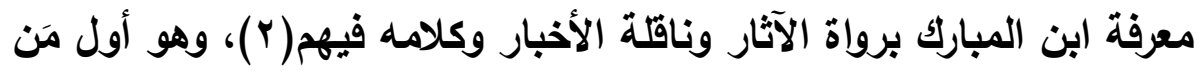

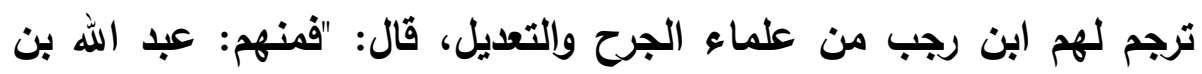
المبارك ابن واضح الخراساني، أبو عبد الرحمن، إمام خراسان، الجامع بين أجناء

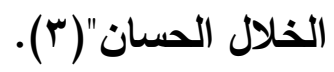
وتظهر آثار هذه السمة على آرائه الحديثية فيما يلي: أنه كان لا يترك حديث الرجل إلا إذا كان في عداد الساقطين:

قال نعيم بن حماد: "كان ابن المبارك لا يترك حديث الرجل حتى يبلغه عنه الثيء الذي لا يستطيع أن يدفعه"( ؛). أنه كان يكتب عن الصغير وإلكبير:

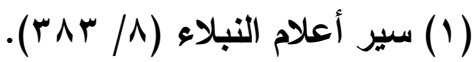

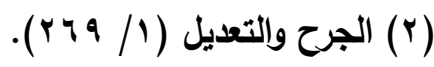

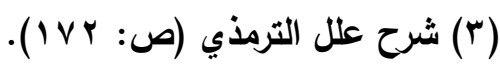

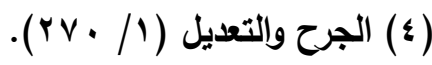




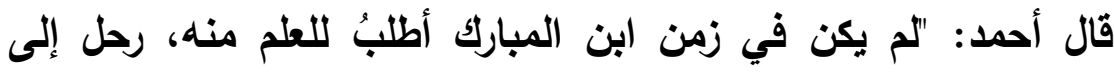
اليمن، وإلى مصر والثشام والبصرة والكوفة، وكان من رواة العلم، وكان أهل

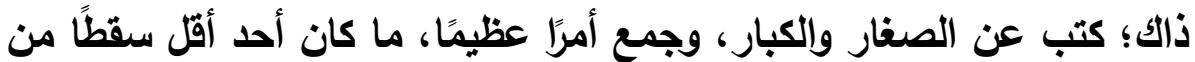
ابن المبارك. وكان يحدث من حفظه، لم يكن ينظر في كتاب"( ). كانت عباراته في الرواة لينة، فهو لا يتكلم فيهم إلا لضرورة، وكان

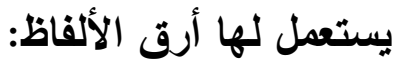

ذُكِكر لابن المبارك حديث رواه الاهفي حبيب بن خالد المالكي فقال: "ليس بثيء، فقيل لابن المبارك: إنه شيخ صالح، فقال ابن المبارك: هو صالح في

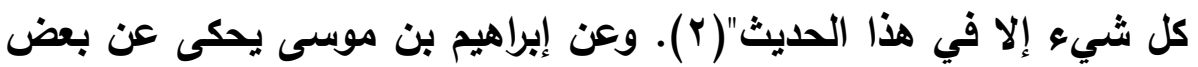

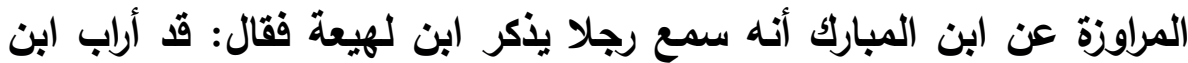

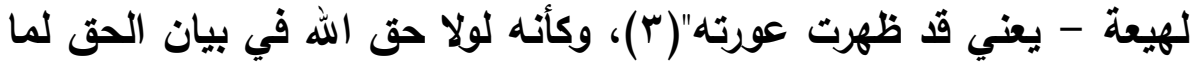

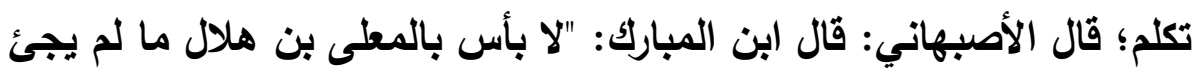

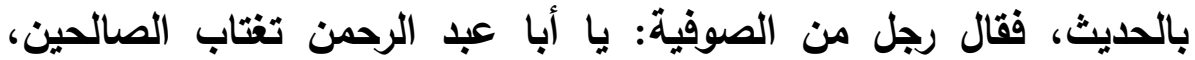

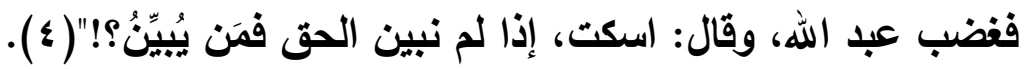

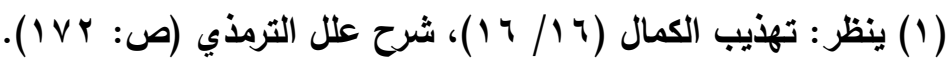

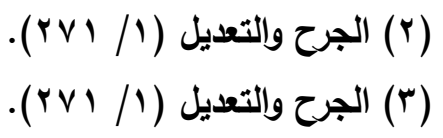
(؛) سير السلف الصالحين، إسماعيل بن محمد بن الفضل بن علي القرثي الطليحي

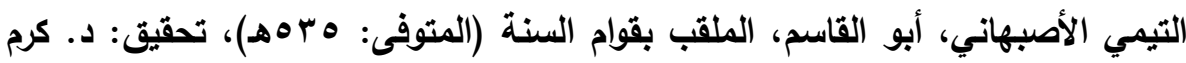

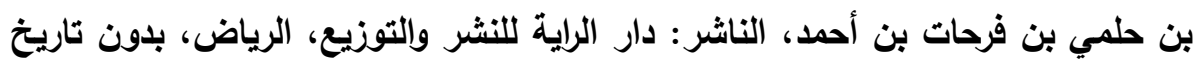

$$
\text { نشر، (ص: مب +1). }
$$


الإنفاق على المُحدِّثين لأجل أن يبثوا العلم:

وعن حبان بن موسى قال: "عوتب ابن المبارك فيما يفرق المال في البلدان، ولا يفعل في أهل بلده، قال: إني أعرف مكان قوم لهم فضل وصِدق، طلبوا الحديث، فأحسنوا الطلب للحديث، يحتاج الناس إليهم، احتاجوا؛ فإن تركناهم

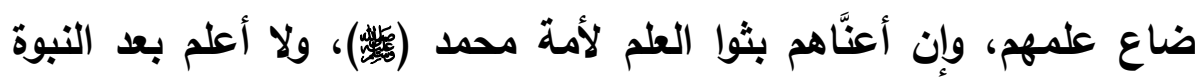
أفضل من بث العلم"( ) - (1).

\section{التوسع في التحديث رغبة في نفع الخلق:}

قال الحسن بن عرفة: "فأقام ابن المبارك بالبصرة أياما، ثم خرج إلى الحج، فخرجت بخروجه فلما قدم بنا مكة أتى الكعبة، فطاف بها سبعا، وطقت بطوافه، ثم صلى خلف المقام ركعتين، فصليت بصلاته، ثم أتى زمزم فاستقى دلوًا، فصبه في ركوة معه، ثم خرج فوقف على باب زمزم ونادى بأعلى صوته: يا أهل مكة، يا أهل مكة، مَن عرفني فقد عرفني، ومن لـ يعرفني فأنا عبد الله بن المبارك المروزي، حدثي عبد الله بن أبي الموال مَكَِّّكُم عن أبي

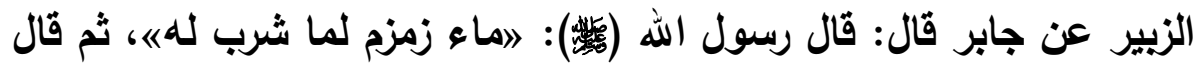
ابن المبارك: اللهم هذا لعطش يوم القيامة، ثم شريه، قال الحسن بن عرفة: فما رأيت أكثر شريا من يومئذ"(ب). كان واحدًا ممن تُحفظ السنة بحياته سوهو داخل في الرحمة بالمسلمين

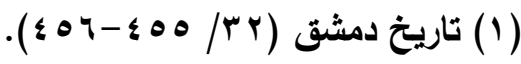

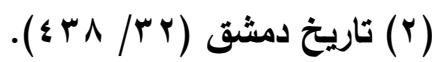




\section{بحفظ دينهم-: - (20)}

قيل له: "هذه الأحاديث المصنوعة! قال: تعيش لها الجهابذة"( )، ويُروى أن هارون الرشيد أخذ زنديقا ليقتله، فقال الرجل: "أين أنت من ألف حديث وضعتها؟ قال: فأين أنت يا عدو الله من أبي إسحاق الفزاري، وابن المبارك

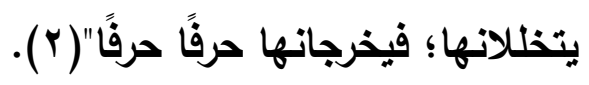

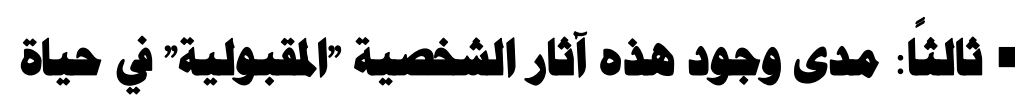
عبد الاله بن المبارك عممهماً

لا يخفى على الناظر ظهور آثار الشخصية المقبولية في أحوال الإمام عبد الله بن المبارك؛ فمن هذه الآثار :

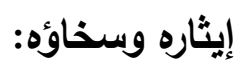

وقد بوَّب الإمام ابن أبي حاتم: باب ما ذكر من سخاء ابن المبارك وطهارة خلقه، ثم ساق قول أبي زرعة: "عبد الله بن المبارك اجتمع فيه فقه وبخاء لإه وشجاعة وغزو، وأشياء"(r)، وقد بلغ به الإيثار إلى أن يُطعم أصحابه أشهى الطعام وهو صائم؛ قال إسماعيل بن عياش: "ما على وجه الأرض مثل عبد الله بن المبارك، ولا أعلم أن الله -عز وجل- خلق خصلة من خصال الخير

$$
\begin{aligned}
& \text { (1) شرح علل الترمذي (ص: Y Y Y). }
\end{aligned}
$$

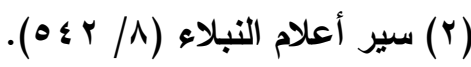

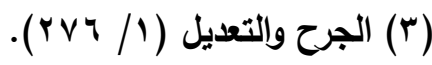


إلا وقد جعلها في

عبد الله بن المبارك، ولقد حدثي أصحابي أنهم صحبوه من مصر إلى مكة، فكان يطمعهم الخبيص(1) وهو الاهر صائم"(Y). ومن مظاهر إيثاره أنه كان يتَّجرِ لا لحاجة إلا لإعانة إخوانه؛ فكان يقول: "لولا فضيل بن عياض ما اتجرث"(r)، وكان يحض على الإنفاق على العيال؛ فيقول: "أول ما يوضع في ميزان المؤمن يوم القيامة ما ينفق على عياله من الحلال"(؛)؛ وهذا السخاء امتدَّ من المال إلى العلم، فشملهما؛ قال المعتمر بن سليمان: "ما رأيت مثل ابن المبارك؛ نصيب عنده الشيء الأي لا يصاب عند أحد" (ه)، وكان يحض أصحابه على بذل العلم؛ فيقول: "أول منفعة العلم أن يفيد بعضكم بعضًا" (7)، ويُحَذِّرهم من البخل بالعلم؛ قال عبد الله بن المبارك: "من بخل بالعلم ابتلي بثلاث: إما بموث فيذهب علمه، أو بالنسيان، أو يبتلى

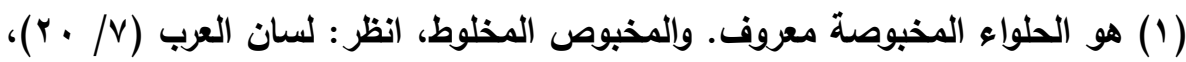
قلت: ولعلها كانت معروفة في زمانه، وهي معمولة من من التمر والسمن. انظر: القاموس المحيط (ص: 7 (1)).

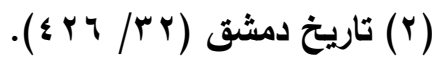

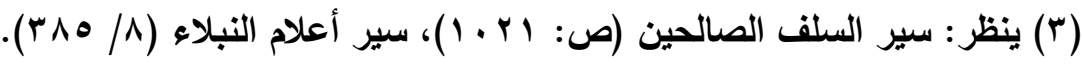

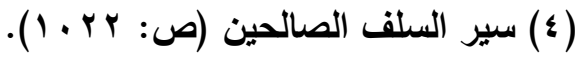

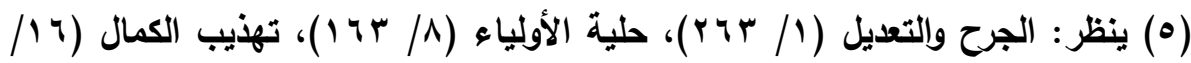

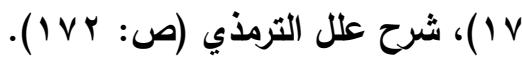

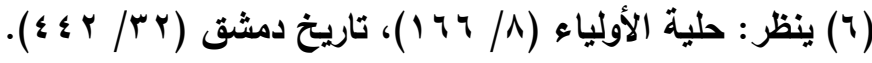


بالسلطان"(1)، ولم يمنعه من السخاء بالعلم ما قـ يلحقه من أذى؛ فعن محمد بن حميا ونوح بن حبيب يقولان: "كنا عند ابن المبارك، فألحوا عليه، قال: هاتوا كتبكم حتى أقرأ، فجعلوا يرمون عليه الكتب من قريب ومن بعيد، فكان رجل من أهل الري يسمع كتاب الاستئنان، فرمى بكتابه فأصاب صلعةَ (بنِ المبارك حرفُ كِتابه؛ فاتشق وسال الدم، فجعل ابن المبارك يعالج الام حتى سكن، ثم قال: سبحان الله، كاد أن يكون قتَّالا، ثم بدأ بكتاب الرجل فقرأه"(ّ). ويلخل في سخائه بذله التصيحة للمسلمين؛ عن عبد الرحمن بن مهدي: "ما رأيت رجلًا أحسن عقلً من مالك بن أنس، ولا رأيت رجلًا أنصح للأمة من

عبد الله بن المبارك" (َّ) ومن مظاهر الشخصية المقبولية: التواضع:

وكان لابن المبارك حظ كبير من التواضع: وقد بوَّب الإمام ابن أبي حاتم: باب ما ذكر من تواضع ابن المبارك وطهارة خلقه(؛)، وذكر آثارًا، منها: "عن زنيج زنيج صاحب الطيالسة(ه) قال: أخبرني فلان - رجل صالح - قال: رأيت ابن

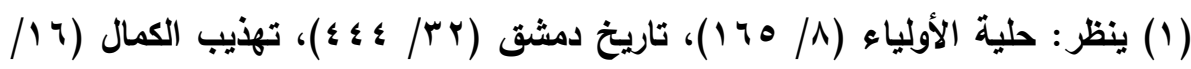

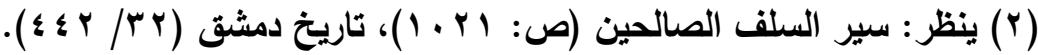

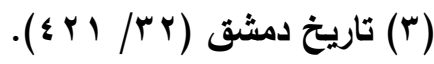

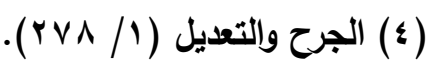
(•) لم أقف على من ذكر سبب تسميته بذلك، وقر ترجمته في كتب التراجم قليل:== 
المبارك وعلى عاتقه طن من حطب ياخل خان قريش"(1".

وعن محمد بن حماد الطلاس قال: أخبرني من رأى ابن المبارك حافيًا بلا خف ولا نعل في شرى حوائجه في السوق()، وعن عيسى بن يونس يقول: كنا بأرض الروم أنا وابن المبارك، فريما استحييت من خدمة ابن المبارك إياي؛ يأخذ بركابي، فإذا نزلنا قدم لنا الخبيص(َ). وقال ابن المبارك: "العُجْبُ: أن ترى أن عندك شيئًا ليس عند غيرك، والكِبْرُ: أن تزدري الناس"(؛)، ولم يكن هذا التواضع لِفقر أو حاجة، بل كان سجية مع الفقراء، وللألك لمَّا سُئل ابن المبارك عن التواضع فقال: "التكبر على ملى

=وهو محمد بن عمرو بن بكر التميمي العدوي اليرازي، أبو غسان الطيالسي، زنيج.

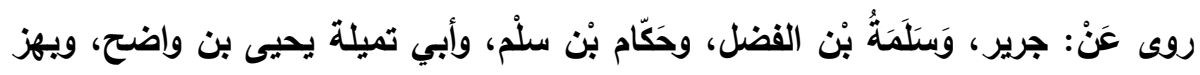
بن أسد، وطائفة.

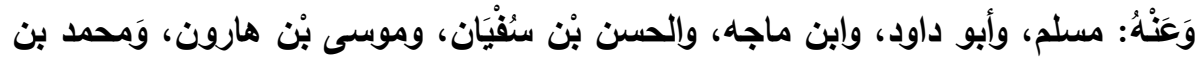

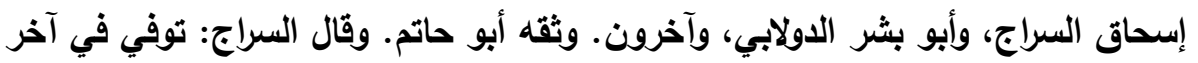
سنة أربعين، أو أول سنة إحدى وأريعين.

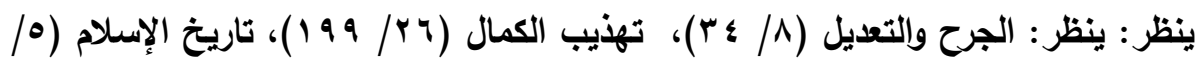

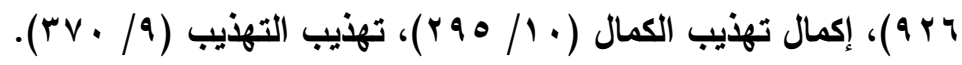

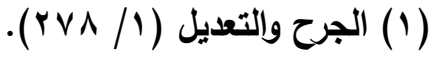

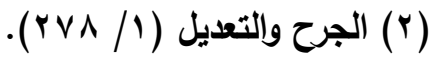

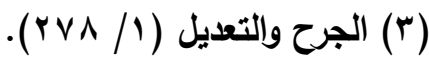

$$
\begin{aligned}
& \text { ( ) سير السلف الصالحين (ص: بr م ـ 1). }
\end{aligned}
$$


الأغنياء"( ) (1) - (1) - (1)

ومن عجيب تواضعه أنه قد يُّذل نفسه تواضعًا، ولا يُّنلٌ حديث رسول

قال ابن أبي الحواري: "جاء رجل من بني هاثم إلى عبد الله بن المبارك

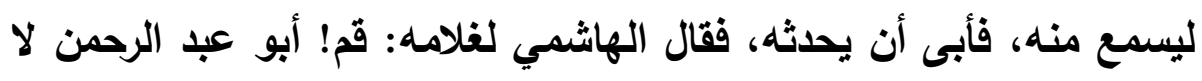

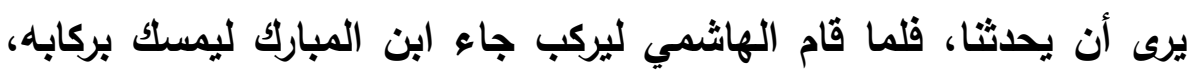

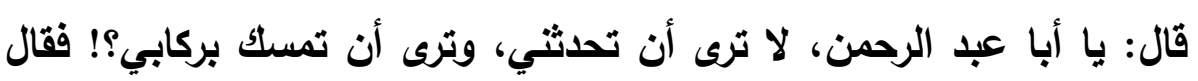

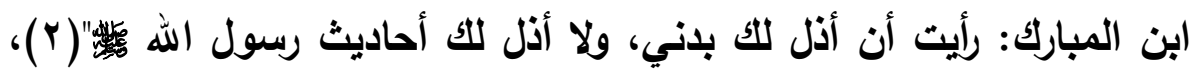

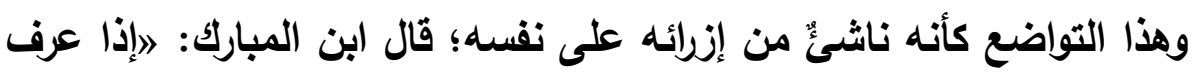
الرجل قر نفسه يصير عند نفسه أذل من الكلبه(؟). ومن مظاهر الثخصية المقبولية: الاستقامة:

وقد كان ابن المبارك علََّ هذا البابٍ؛ فإنها كان في كل باب من أبواب الخير

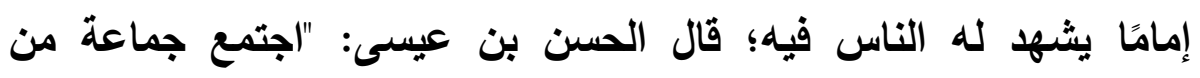

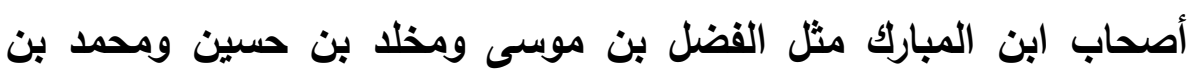
النضر، فقالوا: تعالوا حتى نعد خصال ابن المبارك من أبواب الخير. فقالوا:

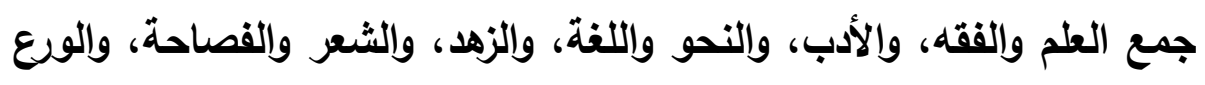

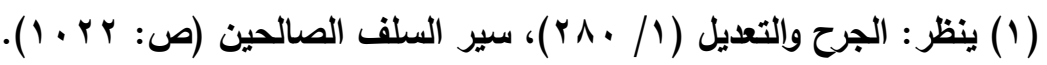

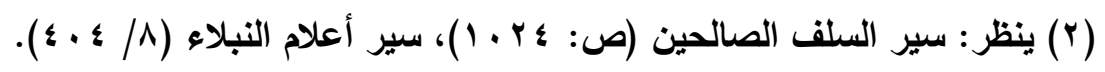

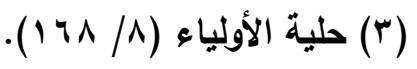


والإنصاف وقيام الليل، والعبادة والحج والغزو، واللخاء والثجاعة

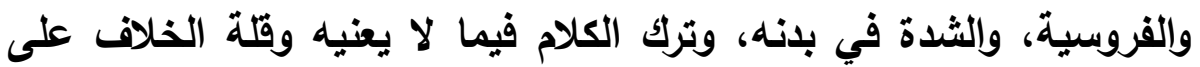

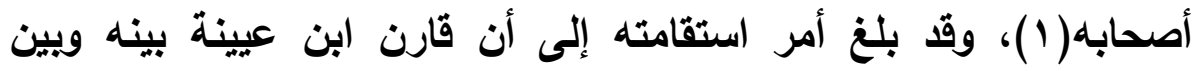

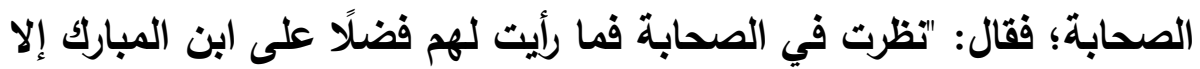

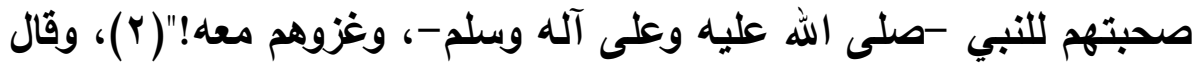

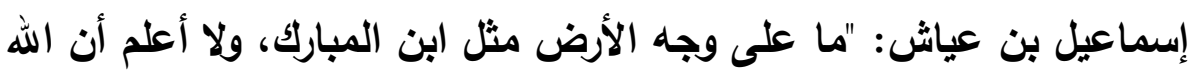

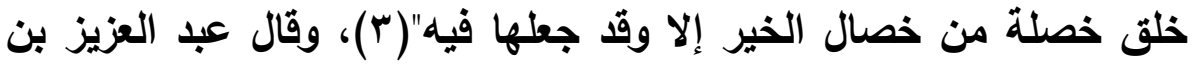
أبي زرمة: "لم تكن خصلة من خصال البر إلا جمعت في ابن المبارك: حياء، وكرم، وحسن خلق، وحسن صحبة، وحسن مجالسة، والزهل، والورع، وكل شيء"(؛)، وقال العباس بن مصعب: "جمع ابن العبارك العديث وإلفقه،

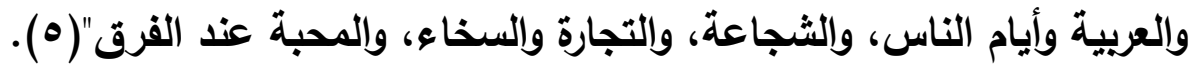
ومن مظاهرها أنه كان يطلب العلم ليعمل وينتفع به؛ قيل لابن المبارك: "كم

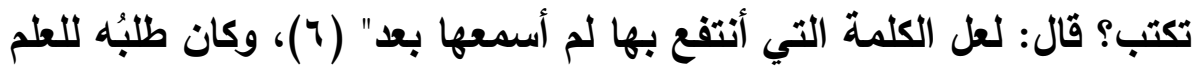

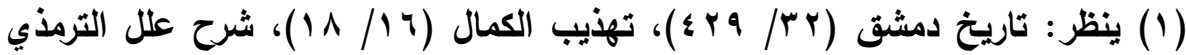

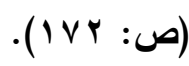

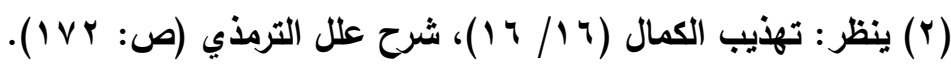

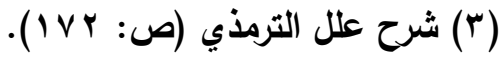

$$
\begin{aligned}
& \text { (\&) شرح علل الترمذي (ص: (IVY). } \\
& \text { (•) شرح علل الترمذي (ص: (IVY) (IVY). }
\end{aligned}
$$

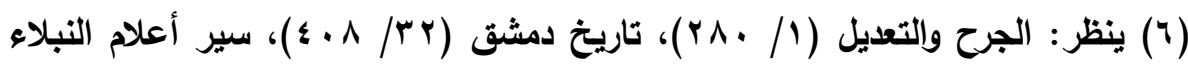
.$(\xi \cdot \odot / \wedge)$ 
بلوغَ الارجة القصوى؛ فقد اجتهذ في الرحلة؛ قال أبو حاتم: "كان ابن المبارك

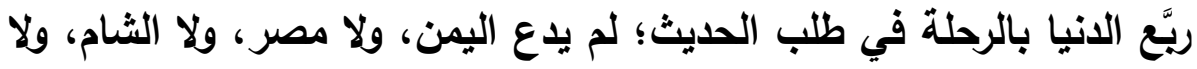
الجزيرة، ولا البصرة، ولا الكوفة"( ()، وهذه العلوم قد استودعها صدره؛ قال

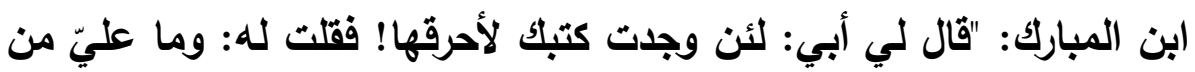
ذلك وهو في صدري"( (ץ).

وقد لخَّص لنا سفيان الثوري الأمر؛ فقال: "لو جهدت جهاي أن أكون في

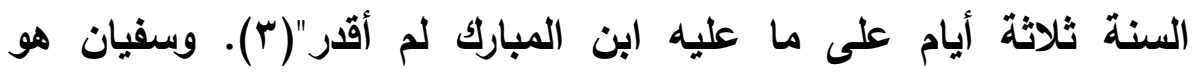

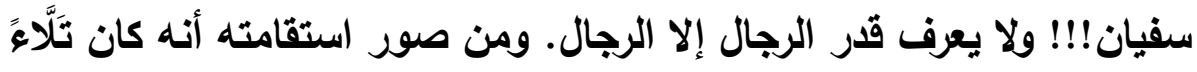
للقرآن متدبرًا؛ قال نعيم بن حماد: "قال رجل لابن الابن المبارك: قرأت البات البارحة القرآن في ركعة، فقال ابن المبارك: لكني أعرف رجلا لم يزل البارحة يقرأ نِعْتَ

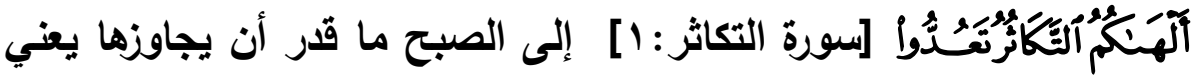

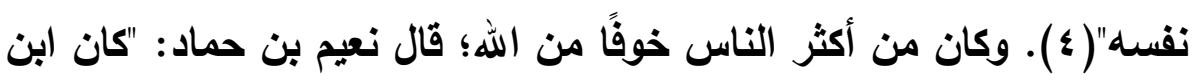

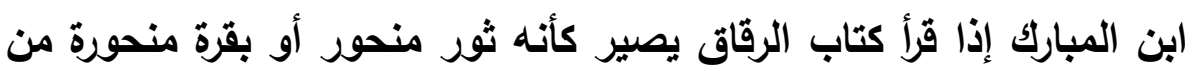

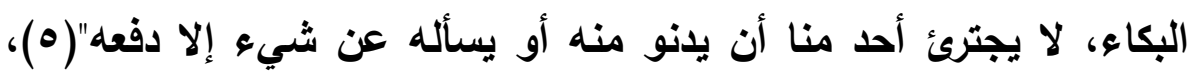

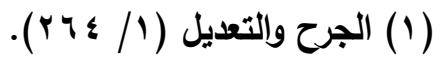

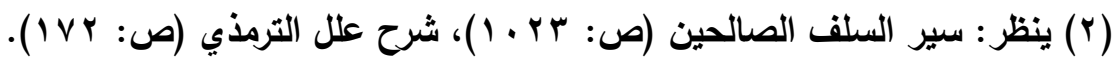

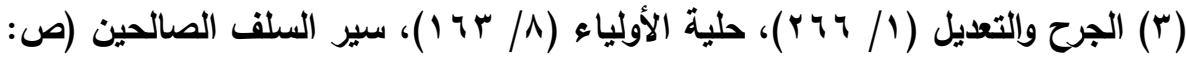

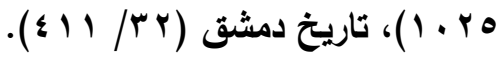

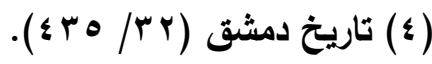

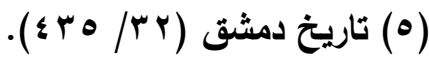


وهذا الخوف أورثه الورع؛ وقد بوَّب الإمام ابن أبي حاتم: "باب ما ذكر من

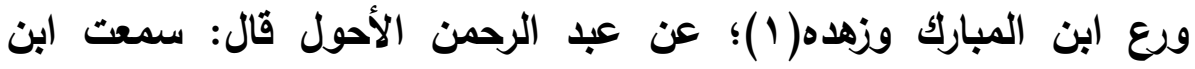

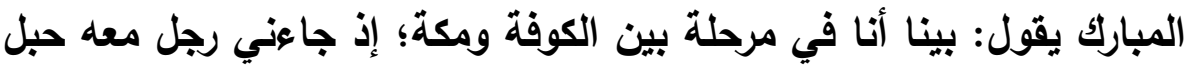
قت، فجلس بين يدي فقال: يا أبا عبد الرحمن، أنا في هذه القرية ليس فيها

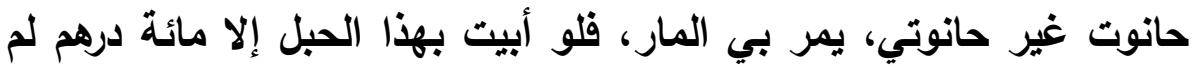

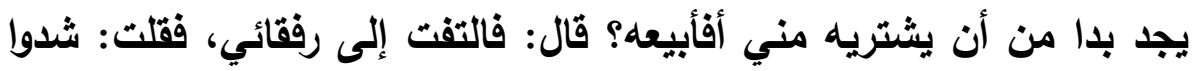
متاعكم، قال: فارتحلت ولم أجبه بشيء، قال فلما صرنا في المرحلة الأخرى قلت لرفقائي: تدرون لم سكت عن صاحب الحبل؟ قالوا: لا، قال كرهت أن

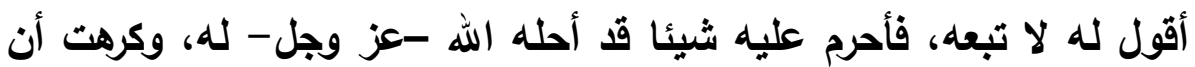
أقول له: بعه؛ فيقطع أيدي الناس وأرجلهم بكلامي، فارتحلت وسكت" (r) (ب).

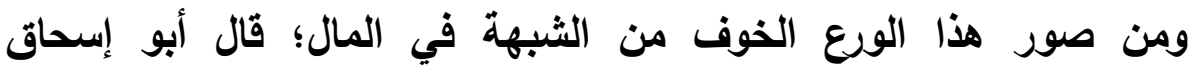

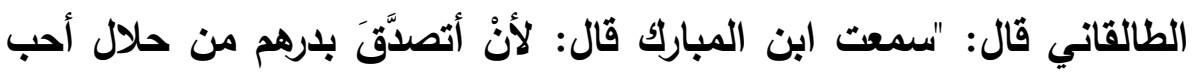

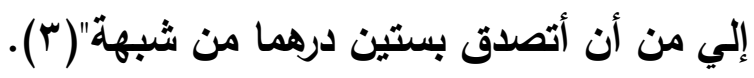
إلا أن هذه الاستقامة كانت مصحوية بإخفاء الأعمال؛ قال علي بن الحسن

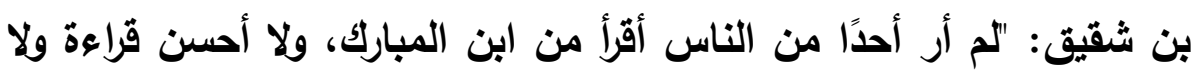
أكثر صلاة منه، كان يصلي الليل كله في السفر وغيره، وكان يرتل القراءة

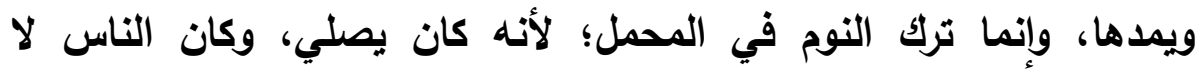

$$
\begin{aligned}
& \text { (1) الجرح والتعديل (1/ / (Y ) ). }
\end{aligned}
$$

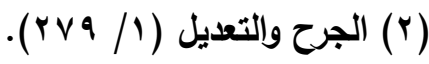

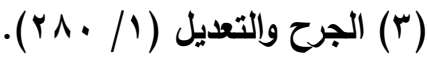


يلرون" (1) (1) وعن محمد بن أعين -وكان صاحب ابن المبارك في الأسفار، وكان كريما عليه-، قال: "كان ذات ليلة ونحن في غزاة الروم ذهب ليضع رأسه، ليريني أنه ينام، فقلت أنا برمحي في يدي، قبضت عليه ووضعت أنه رأسي على الرمح كأني أنام كذلك، قال: فظن أني قـ نمت، فقام فأخذ في صلاته فلم يزل كذلك حتى طلع الفجر وأنا أرمقه، فلما طلع الفجر جاء فأيقظني -وظن أني نائم- وقال: يا محمد، فقلت: إني لم أنم، قال: فلما سمعها مني ما رأيته بعد ذلك يكلمني، ولا ينبسط إلي في شيء من غزاته كلها؛ كأنه لم يعجبه ذاك مني لما فطنت له من العمل، فلم أزل أعرفها فيه حتى مات، ولم أر رجلًا قط أسر بالخير منه"(r). وعن عبد الله بن سنان قال: "كنت مع ابن المبارك والمعتمر بن سليمان بطرسوس فصاح الناس: النفير النفير، قال فخرج ابن المبارك والمعتمر، وخرج الناس، فلما اصطف المسلمون والعدو، خرج رجل من أهل الروم يطلب البراز، فخرج إليه مسلم؛ فشد العلج (ب) على المسلم فقتل المسلم حتى قتل ستة من المسلمين مبارزة، فجعل يتبختز بين الصفين يطلب المبارزة لا يخرج إليه أحد، قال: فالتفت إليَّ ابن المبارك فقال: يا عبد الله، أن حدِّث بي حدث كذا وكذا، قال: وحرلك دابته، وخرج العلج فعالج معه ساعة، فقتلَ العلجَ، وطلب المبارزة؛ فخرج إليه علج آخر فقتله، حتى قتل ستة من العلوج مبارزة، وطلب البراز؛

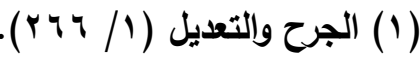

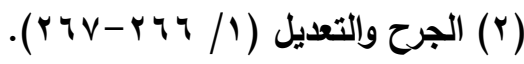

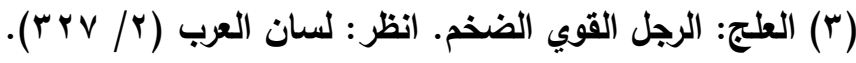


فكأنهم كاعوا عنه؛ فضرب دابته ونظر بين الصفين، وغاب فلم أشعر بشيع إذا أنا بابن المبارك في الموضع الذي كان، فقال لي: يا عبد الله، لئن حدثت بهذا أحدا وأنا حي! فنكر كلمةً؛ قال: فما حدثت به أحدا وهو حي" (1). ومن مظاهر الاستقامة: تتعمه بحديث رسول الله: قال نعيم بن حماد: "قيل لابن المبارك: يا أبا عبد الرحمن، تكثر القعود في البيث وحدك؟ قال: أنا وحدي! أنا مع النبي (范) وأصحابه -يعني النظر في الحديث-"(Y). وهو جزء من معرفته بالله سوقد ذاق حلاوتها-؛ قال الحسين بن الحسن المروزي، قال: سمعت ابن المبارك، يقول: "أهل الدنيا خرجوا من الدنيا قبل أن بتطعموا أطيب ما فيها، قيل له: وما أطيب ما فيها؟ قال: المعرفة بالله -عز

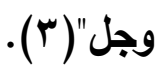

إن الناظر إلى مثل هذه الشخصية يظن أنه لا بـ منذ نعومة أبصاره قـ تلقى تربية عزيزة النظير، إلا أن المفاجأة أنه كان شابًا بطاَلا، ثم هداه الله، فاستقام؛ فعن حسين بن الحسن قال: "سئل ابن المبارك وأنا حاضر عن أول زهده، فقال: إني كنت يومًا في بستان وأنا شاب مع جماعة من أترابي، وذلك في وقت القواكه؛ فأكلنا وشربنا، وكنت مولعًا بضرب العود، فقمت في بعض الليل وإذا غصن يتحرك عند رأسي، فأخذت العود لأضرب به؛ فإذا بالعود

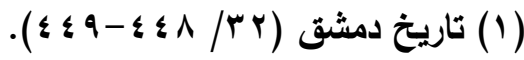

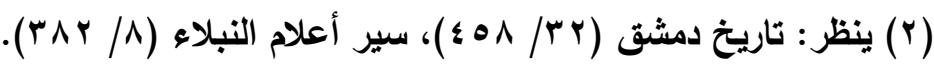

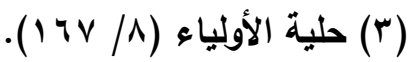




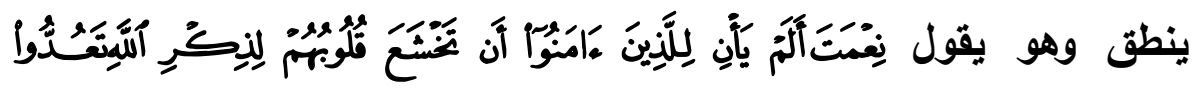

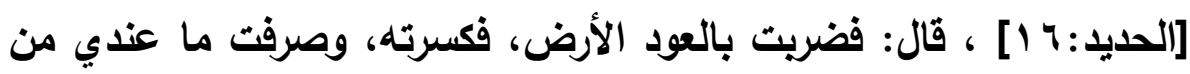

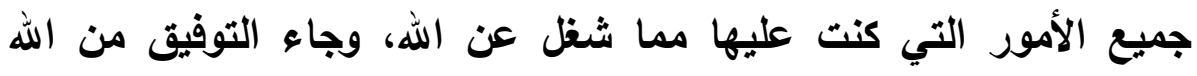
تعالى، فكان ما سهل لنا من الخير من فضل الله تعالى ورحمته"( (1). ثم إنه أدرك أنه فاته الصحابة أصحاب الأدب العظيم؛ فأب في طلبه، وهو

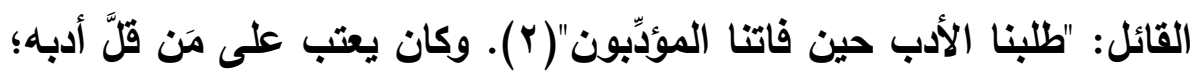

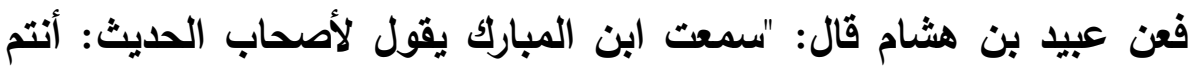

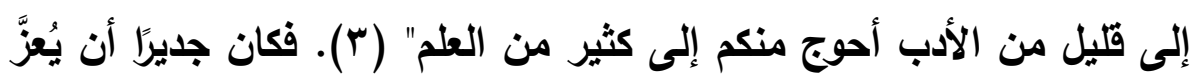

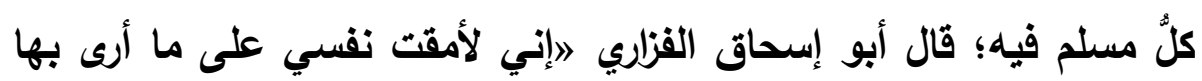

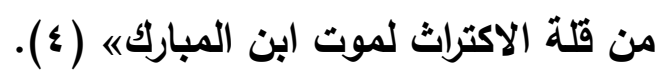

$\operatorname{sen} \Delta \cos$

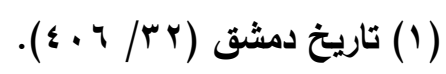

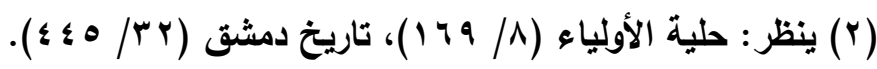

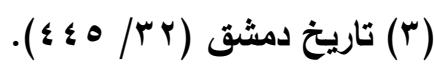

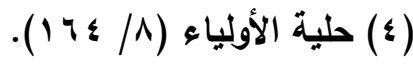




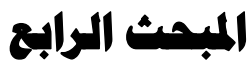

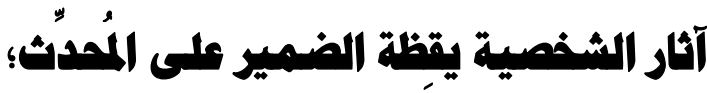

\section{(سمة البمث والتفتيش والتنقيب ولى المقيقة) أنمدوذبًا}

قام البحث في التعريف بالعوامل الكبرى الخمسة الشخصية: يقظة الضمير، ويُقابلها: عدم الاكتراث وقدمنا أن أوجه الشخصية يقِظة الضمير الستة هي: الكفاءة، الانتباه لإنجاز المهام، الطاعة والالتزام بالواجبات المكلف بها، التفاني لتحقيق الأهداف، الانضباط، التشاور، وأقرب سمة لهذه الشخصية هي البحث والتقتيش والتتقيب عن الحقيقة.

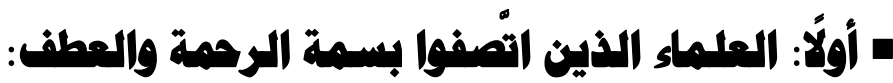
اتصف طائفة من علماء الحديث -رحمهم الله تعالى- بالاهتمام البالغ في البحث عن الحقيقة، حتى ولو كلقهم ذلك ترحالًا وسفرًا ومشقةً! فهم لا يكلون ولا يملون؛ إذ غايتهم الوصول إلى حقيقة الأمر. وممن اتَّصف بهذه السمة من العلماء: شعبة بن الحجاج - رحمه الله - ( 1 هـ) • وسنُفرده بالبحث. أبو عبد الرحمن المؤمل بن إسماعيل: وله قصة عجيبة في تتبع حديثٍ واحدٍ في قرابة ثلاثة أشهر (1).

(1) الكفاية في معرفة أصول علم الرواية، أبو بكر أحمد بن علي بن ثابت بن أحمد بن

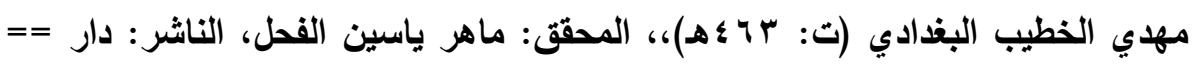
10. هجلة كلية اصول الدين والدعوة / العدد السابع و الثّلاثون 9 ا ـ بم ـ الجزء الاول 
أبو حاتم محمد بن إدريس اللرازي: وقد وصفه الذهبي بسمة البحث

والتفتيش والتنقيب، وهو من أكثر المُحدِّثين رحلة في طلب الحديث ( ( ).

هانياً: اتصاف شعبة بسمة البمث والتنقيب عن المقيقة، ونماذه

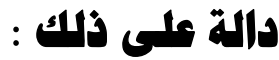

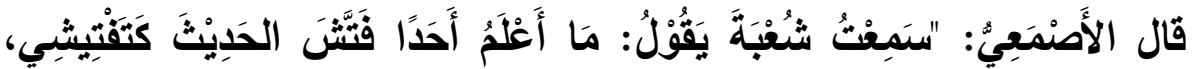

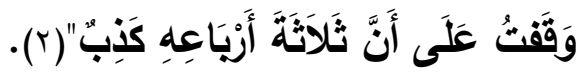

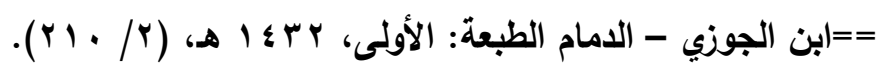

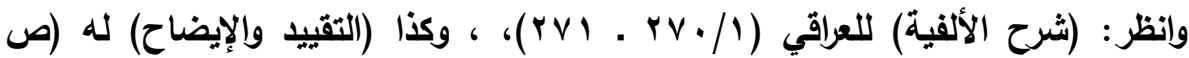

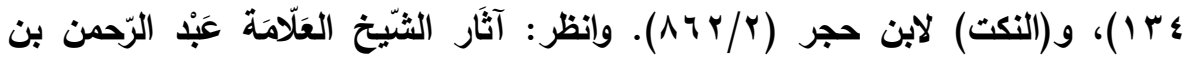

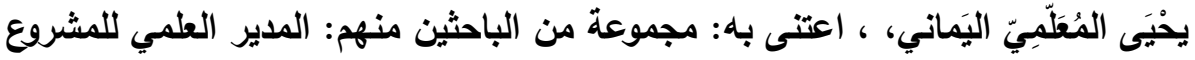

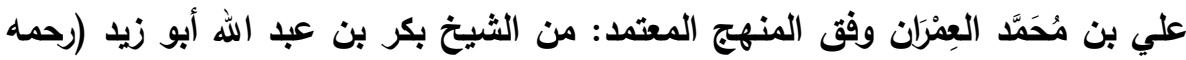

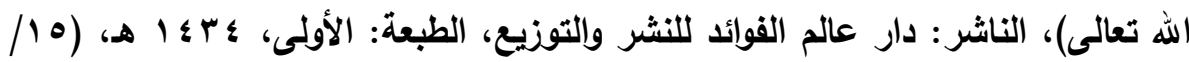
. (rYr

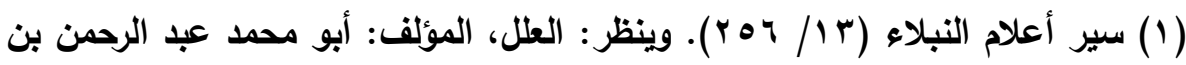

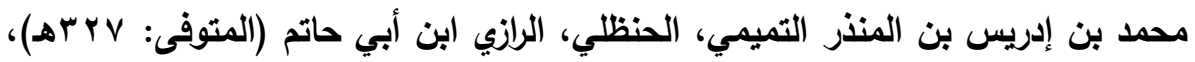

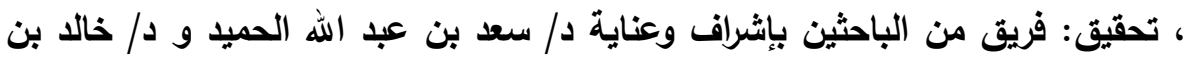

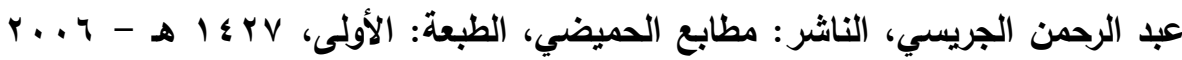

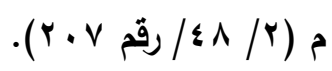

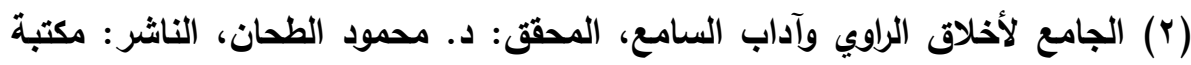

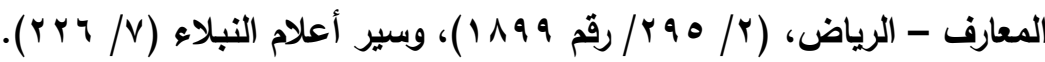


وقد وصفه بسمة البحث والتقتيش جماعة:

قال الحافظ ابن حبان (ت ؟هب هـ): "وهو أول من فتش بالعرلق عن أمر المُحدِّثين وجانب الضعفاء والمتروكين حتى صار عَلًَا يقتدى به، ثُ تبعه

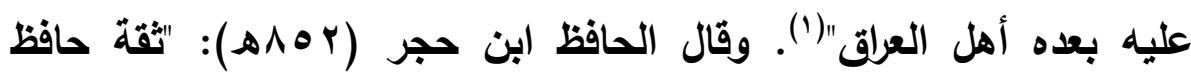
متقن، كان الثوري يقول: هو أمير المؤمنين في الحديث، وهو أول من فتنَّ

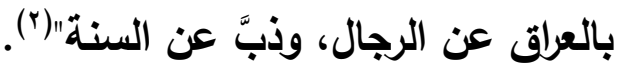
ولم يقف التفتيش على الأسانيد، بل كان يُنَقِبُ عن علل الأحاديث؛ قال

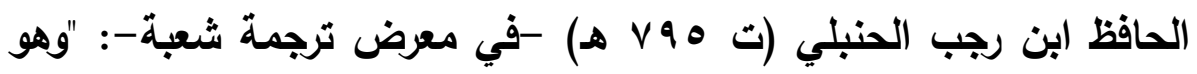

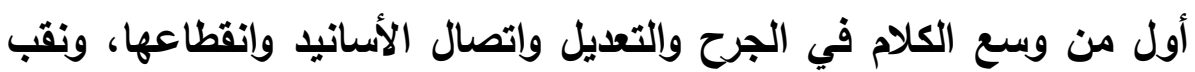
عن دقائق علم العلل. وأئمة هذا الشأن بعده تبع له في هذا ولئ العلم" (").

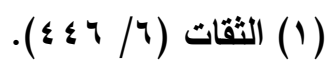

(r) تقريب التهذيب، أبو الفضل أحمد بن علي بن محمد بن أحمد بن حجر العقلاني

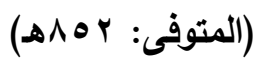

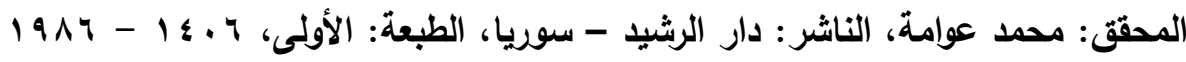

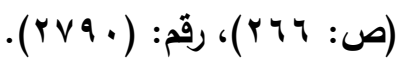

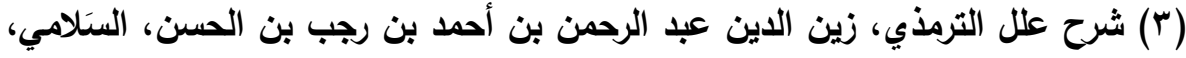

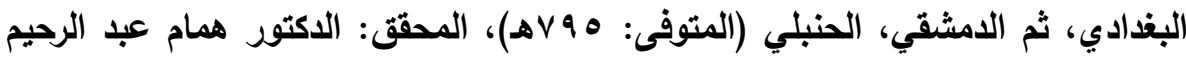

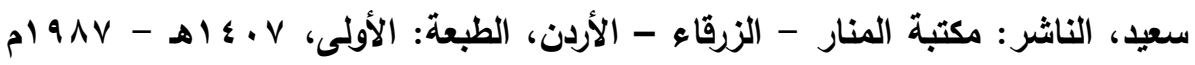

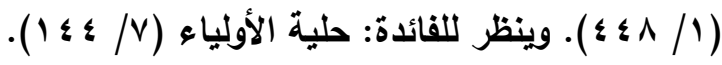




\section{" نماذه ثدل على اتصافه بسمة البمث والتفتيش والتثبت:}

كان من عادة شعبة - رحمه الله تعالى - أنه لا يرضى بسماع الحديث مرة

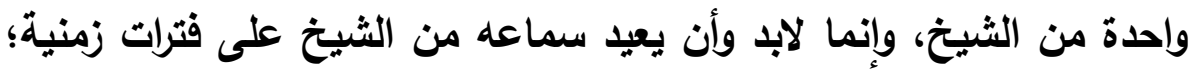

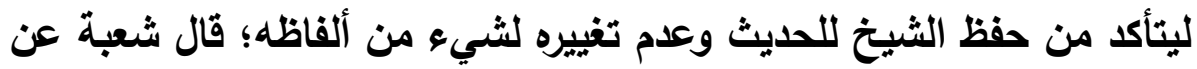

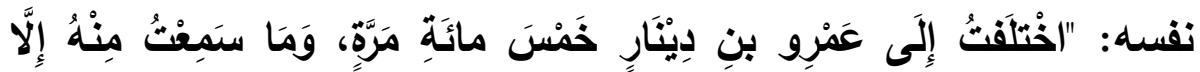

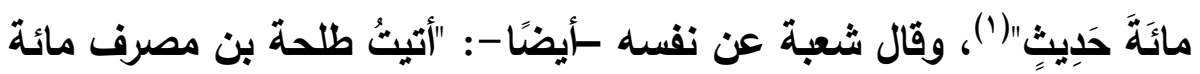

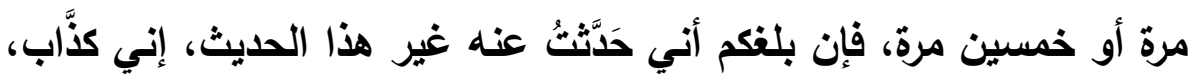
والحديث هو حديث طلحة عن عبد الرحمن بن عوسجة عن البراء عن النبي

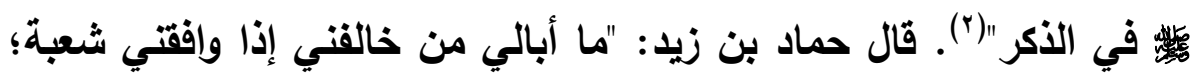

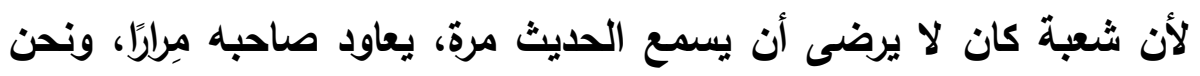

كنا إذا سمعناه مرة اجتزينا بهه"(r).

بل وصل طلبُ الحقيقةٍ وإلتثبتُ بشعبةَ أنه يستحلف شيخه عبد الله بنَ دينار! قال عبد الرحمن بن أبي حاتم: "سمعثُ أبي وذكر حديث عبد الله بن دينار

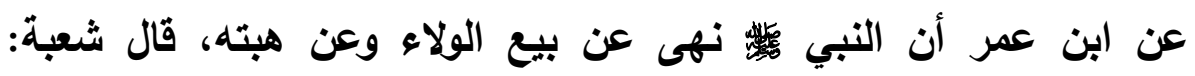

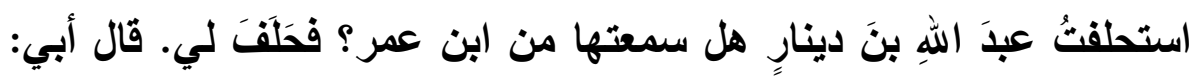

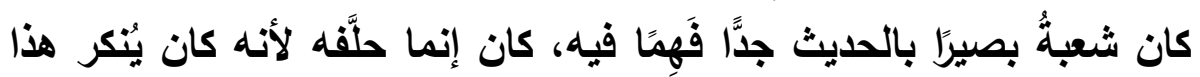

$$
\begin{aligned}
& \text { (1) سير أعلام النبلاء (Y) (Y (Y (Y). }
\end{aligned}
$$

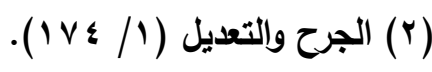

$$
\begin{aligned}
& \text { (r) الجرح والتعديل (1/ 1 1 1) ). }
\end{aligned}
$$


الحديث، حُكْمّ من الأحكام عن رسول الله لَّد لم يشاركه أحد، لم يرو عن ابن

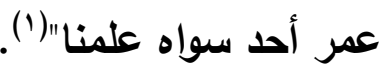

عدم ملل شعبة من سؤال الثيوخ والتثبت من سماعهم للأحاديث، بل

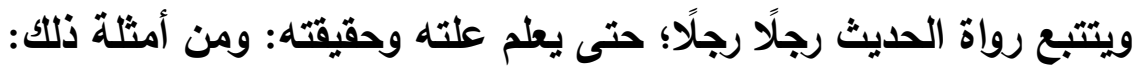

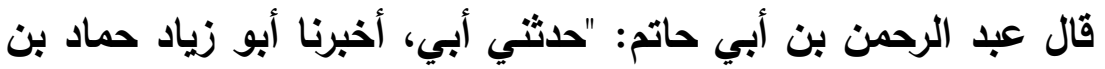

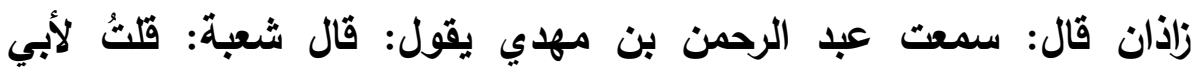
إسحاق: مَن حَبَّثك عن علي بن ريبعة قال: كنتُ ردف عليّ فلما ركب قال:

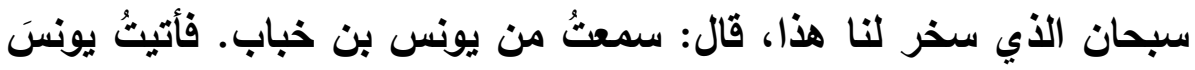

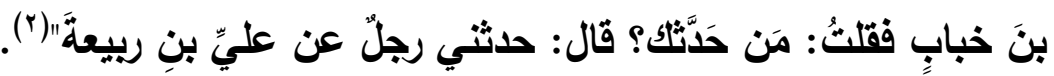

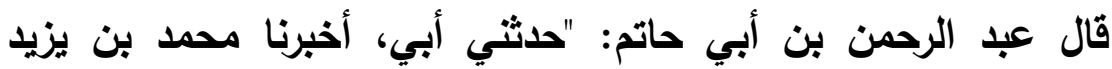

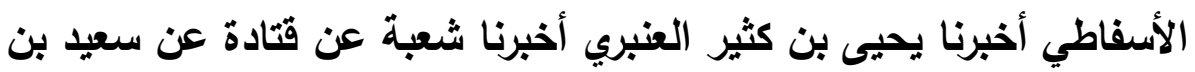

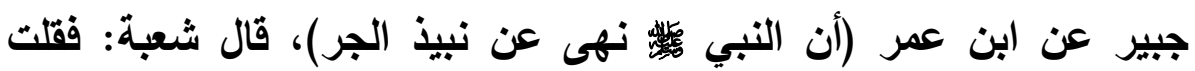

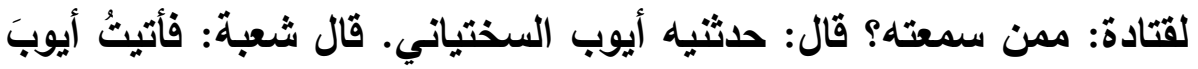

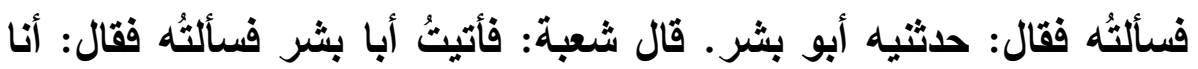

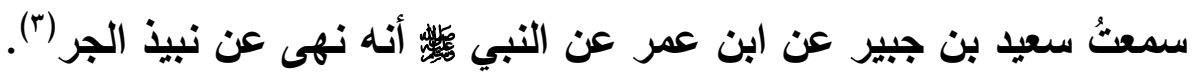

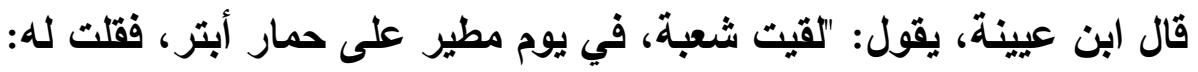
إلى أين؟ قال: أذهب إلى الأسود بن قيس، فقد حئ حئنا عام كذا بأحاديث أبصر

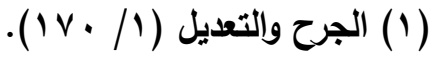

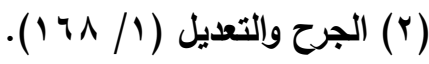

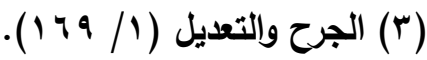




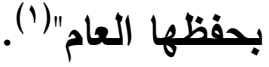

ثم نذكر نموذجًا عزيز الوجود والنظير في حرص شعبة على البحث،

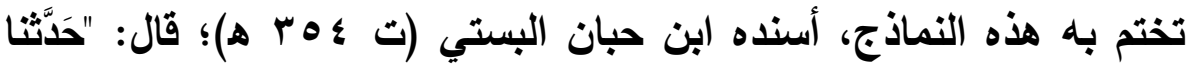
عبد الله بن قَحطَبة بفم الصلح، قال: حَدَّثا أحمد بن زكريا الواسطي، قال: سمعتُ أبا الحارث الوراق، يقول: جلسنا على باب شعبة نتذاكر السند فقلت: حَدَّنَا إسرائيل، عن أَبِي إِسحاق عن عبد الله بن عطاء عن عقبة بن عامر عن التبي شاء)، فخرج شعبة بن الحجاج وأنا أحدث بهذا الحديث، فصفعني ثم قال: يا مجنون، سمعتُ أبا إسحاق يحدثُ عن عبد الله بن عطاء عن عقبة بن عامر، فقلتُ: يا أبا إسحاق: سمعتَّ عبد الله بن عطاء يحدثُ عن عقبة بن عامر؟ قال: سمعتُ عبد الله بن عطاء، قلتُ: عبد الله سمع عقبة بن عامر؟ فقال: اسكتُ، فقلتُ: لا أسكتُ، فالتقتَّ إليَّ مسعر بن كدام فقال: يا شعبة، عبد الله بن عطاء حيٌّ بمكةَ، فخرجتُ إلى مكة؛ فلقيت عبد الله بن عطاء، فقلت: حديث الوضوء، فقال: عقبة بن عامر؟ قلت: يرحمك الله سمعتَّ منه؟ قال: لا، حلثي سعد بن إبراهيم، فمضيتُ، فلقيتُ سعد بن إبراهيم، فقلت: حديث الوضوء، فقال: مِن عندكم خرج، حدثي زياد بن مخرق، فانحدرث إلى البصرة، فلقيثُ زياد بن مخراق وأنا شحب اللون وستخ الثياب كثير الشعر، فقال: من أين؟ فحدثته الحديث، فقال: ليس هو من حاجتك، قلت: فما بل، قال: حتى تذهب تلخل الحمام، وتغسل ثيابك ثم تجيء فأحدثك به، قال: 
فرخلتُ الحمامَ، وغسلثُ ثيابي ثم أتيتُه، فقال: حدثي شهر بن حوشب، قلثُ: شهر بن حوشب عمَّن؟ قال: عن أَبي ريحانه، قلتشُ: هذا حديث صعد ثم نزل؛ دمروا عليه ليس له أصل"(') وذكر له طريقًا آخر، ثم قال: قال الحافظ محمد

(1) المجروحون من المحثين والضعفاء والمتروكين / الناشر: دار الصميعي - الرياض،

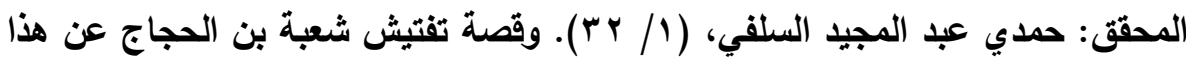

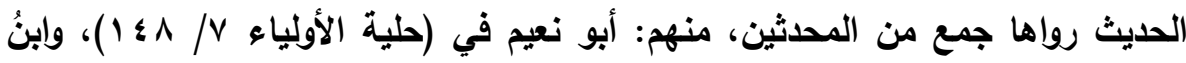

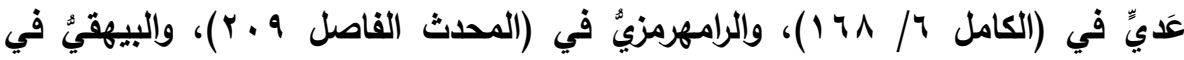

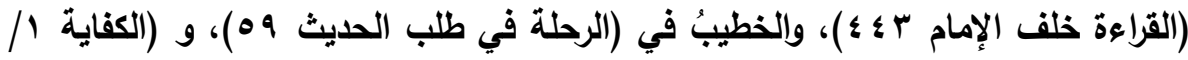
(التمهيد

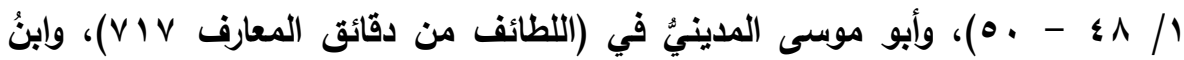

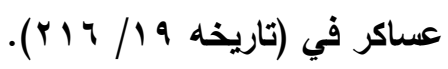

وهذا السندُ وإن كان فيه نصرُ بنُ حمادٍ الورلقُ، فقد قالَ ابنُ حَجرٍ : "ضعيفُّ" (التقريب .$(\mathrm{V}) \cdot \mathrm{q}$

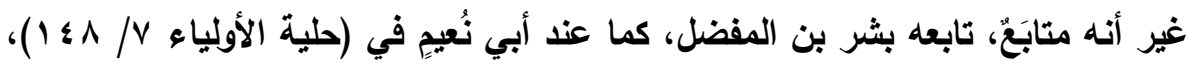

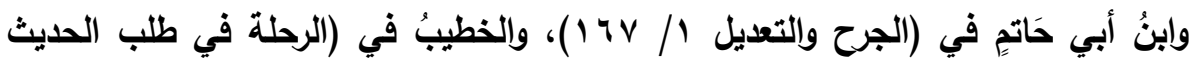
. ( 7 .

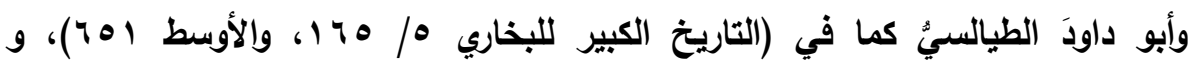

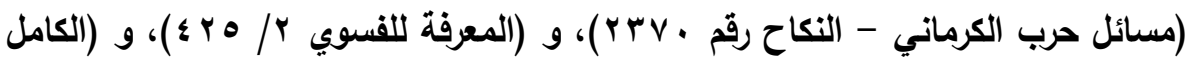

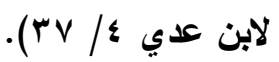

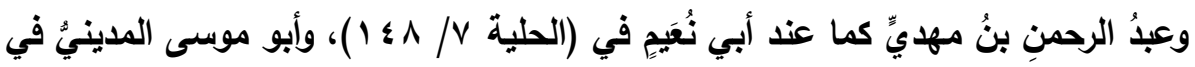

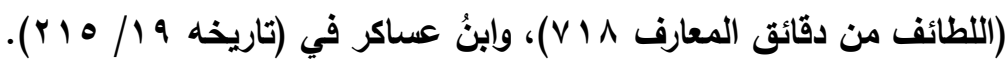

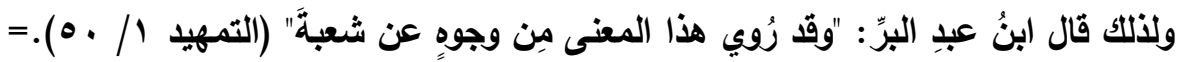


بن حبان البستي - رحمه الله- معلقًا على ذلك: "فهذا كان دأب شعبة في تفتيش الأخبار والبحث عن سقيم الآثار، ولم يكن يعد السماع من الثيخ إلا

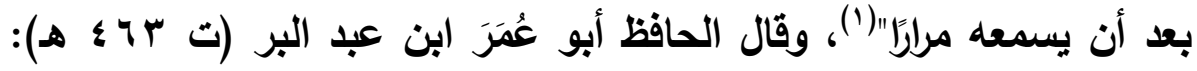

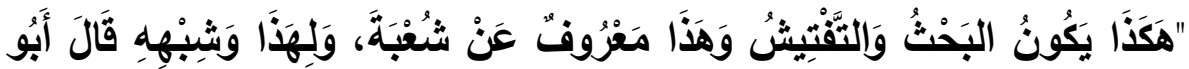

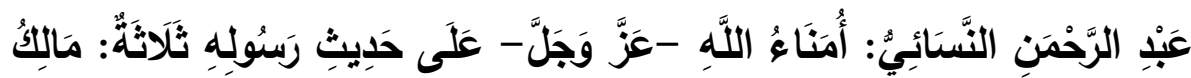

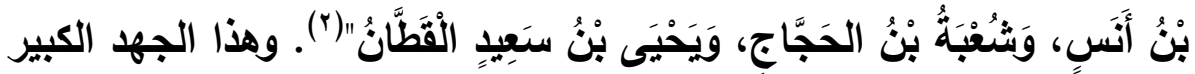
والمشقة البالغة والسفر الطويل كله للتحقق من صحة حديث واحد.

\section{ه ثالثاً: آثار سمة البمث والتفتيش والتنقيب على علم المديث}

\section{ومكانة شعبة وآرائه المديثية:}

كان لهذه السمة آثار في علم الحديث عمومًا، وعلى مكانة شعبة الحديثية

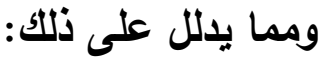

نثأة علم الرجال والتتقيب عليهم؛ فهو أول من تكلم بهذا العلم، وقد

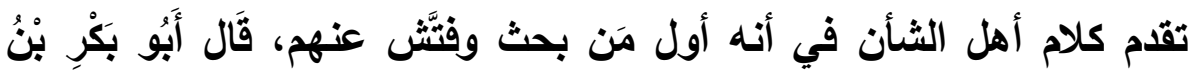

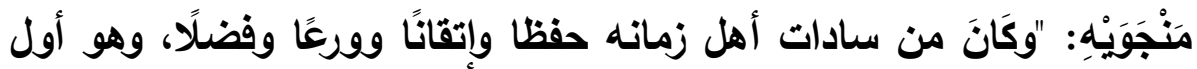

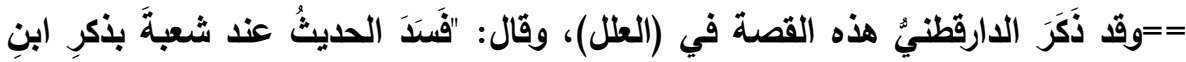

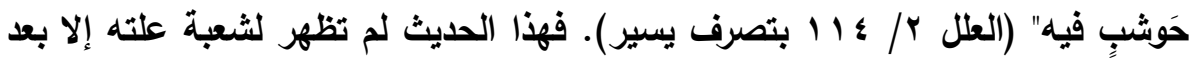
فترة ويعد كَّ وسفرات ورحلات.

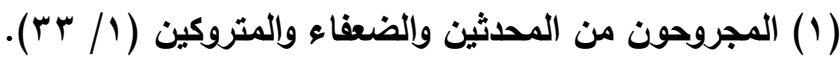

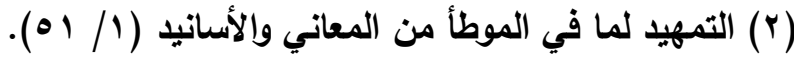


من فتش بالعرلق عَنِ أمر المُحدِّثين، وجانب الضعفاء والمتروكين، وصار

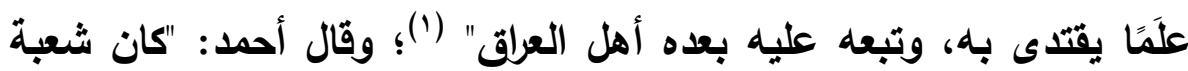
أمة وحده في هذا الثنأن يعني في الرجال، ويصره في الحديث وتثبته وتئه وتنقيته

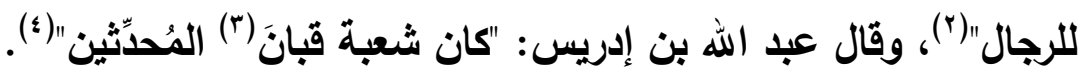

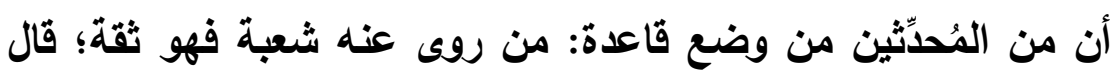

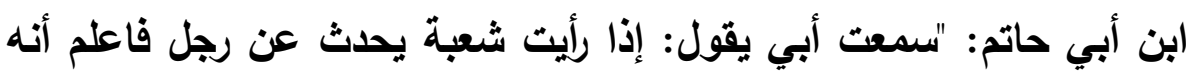

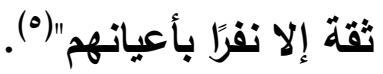
أن شعبة صار هو الذي إليه المنتهى في هذا الباب؛ فئأمر الطلاب

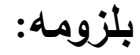
قَال حماد بْن زيد: "قال لنا أيوب: الآن يقلم عليكم رجل من أهل واسط

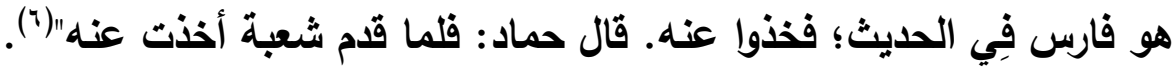

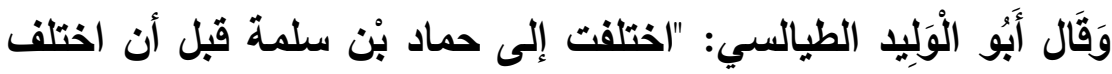

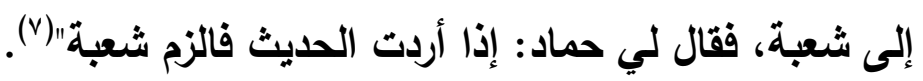
أن الحفاظ صاروا يعرفون صحة محفوظهم بمقارنتهم بمرويات شعبة؛

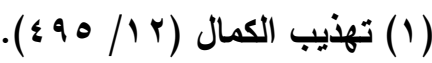

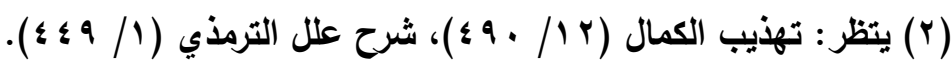

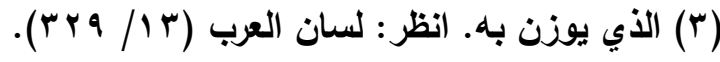

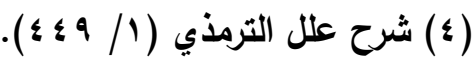

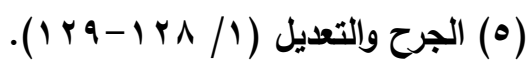

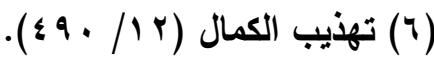

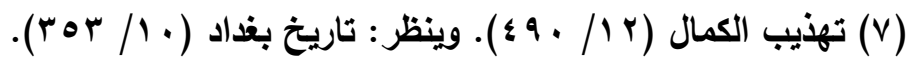


قال أبو الوليد: "وسمعت حماد بن زيد يقول: لا أبالي من خالفني إذا وإفتني

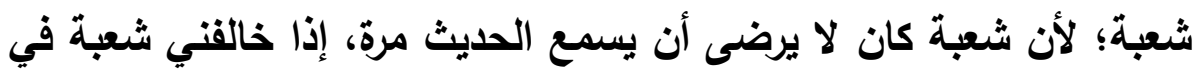

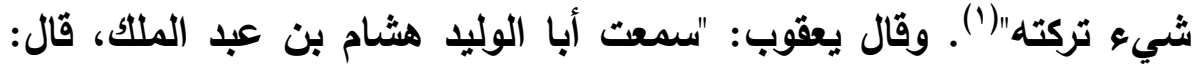

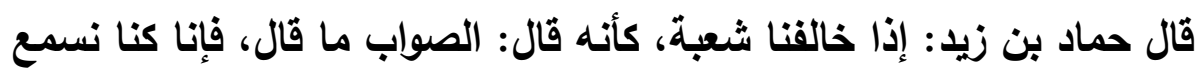

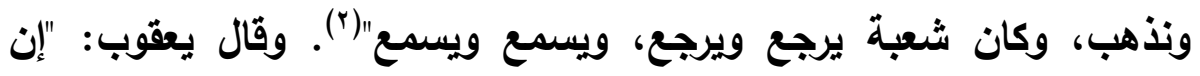

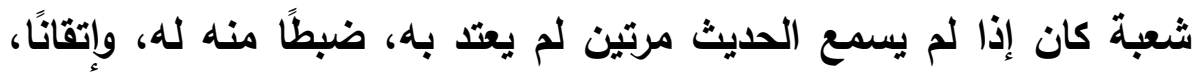

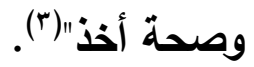

ه - أن من الحفاظ الكبار من صار يراجع أحاديث نفسه على شعبة؛ كقتادة:

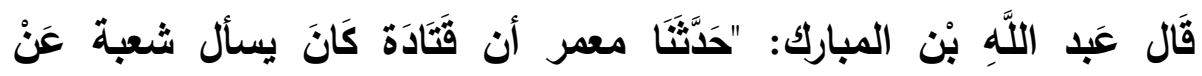
حديثه" (i) علق ابن أبي حاتم؛ فقال: "وكان قتادة بارع العلم نسيجَ وحدِهِ في الحفظ في

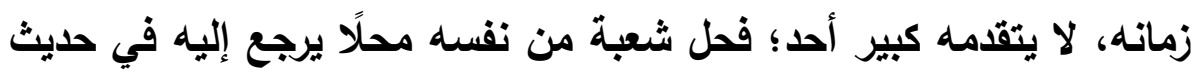

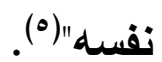

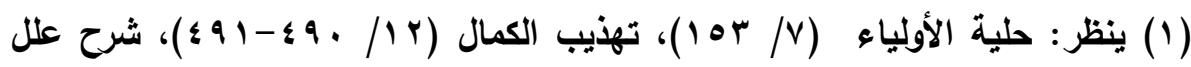

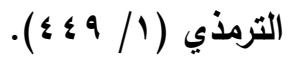

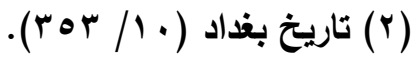

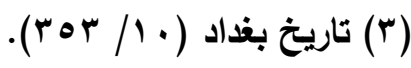

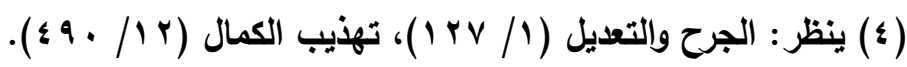

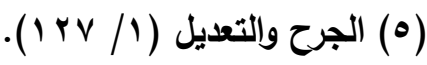


צ- إحجام الكذابين ومَن يروي الأكاذيب من روايتها خوفًا من شعبة؛ فقد

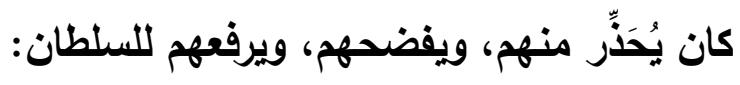

قال مكي بن إبراهيم: "كان شعبة يأتي عمران بن حدير، فيقول: اتعالى يا

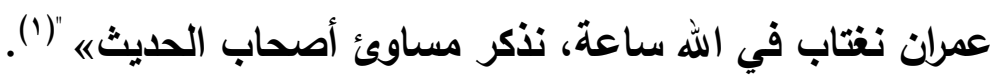
وقََال الثافعي: "لولا شعبة ما عرف الحديث بالعرلق، وكان يجيء إلى الرجل

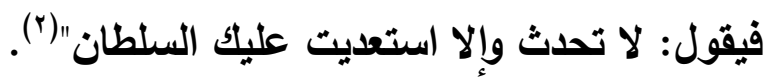
= رابعاً: هدى وجود آثار الشفصية يقطة الضمير في هياة شعبة عموهí: مما يدعو إلى الحيرة في شخصية الإمام شعبة؛ ما يلاحظ من كونه صاعقةً

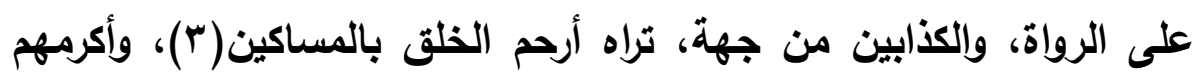

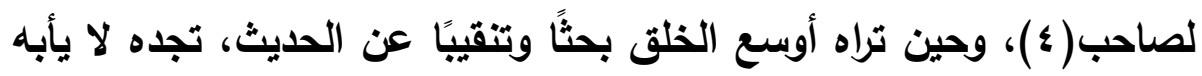

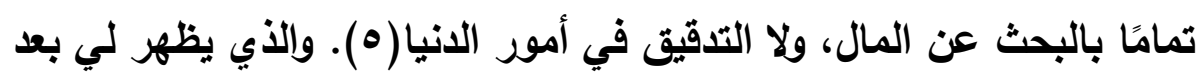

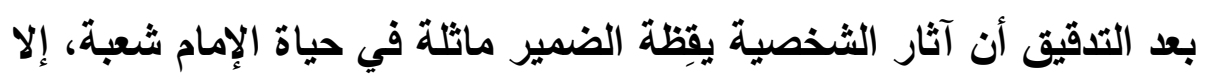

$$
\begin{aligned}
& \text { (1) حلية الأولياء (Y) r (1) (1). }
\end{aligned}
$$

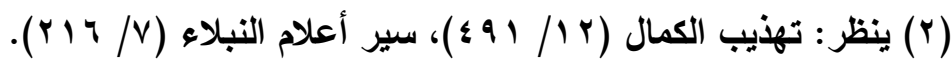

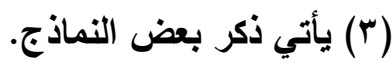

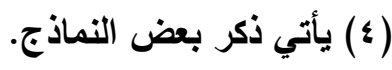

$$
\begin{aligned}
& \text { (•) يأتي ذكر بعض النماذج. }
\end{aligned}
$$


أن طلبه علم الإسناد حسبةً لله، أورثه تذاخلًا في أنماط الثخصية(1)، ومن

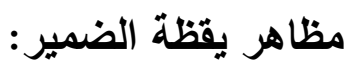

- الكفاعة، والتفاني في إنجاز المهام:

ويكفي في التدليل عليها ما قدمه البحث أول الكلام على شخصية الإمام في

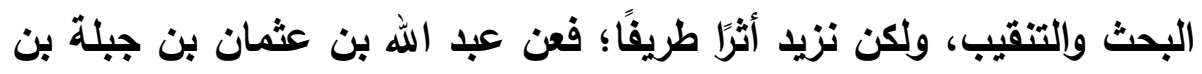

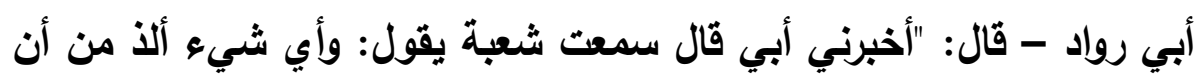

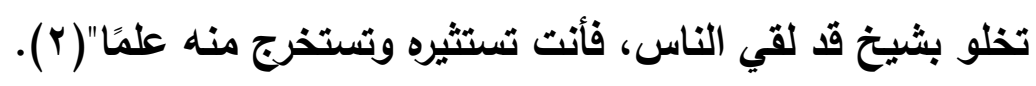
التثاور:

عن حماد بن زيد قال: كلمنا شعبة وعباد بن عباد وجرير بن حازم في رجل،

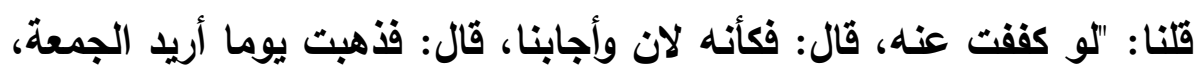

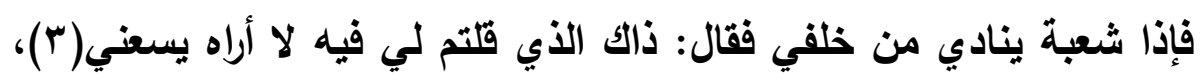

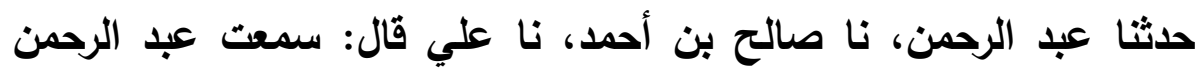

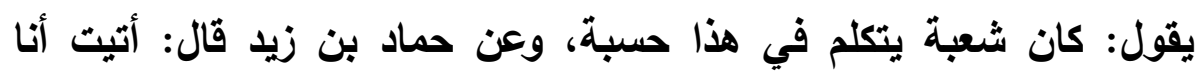

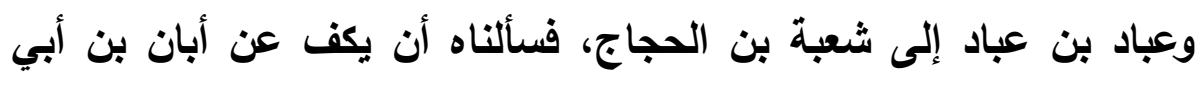

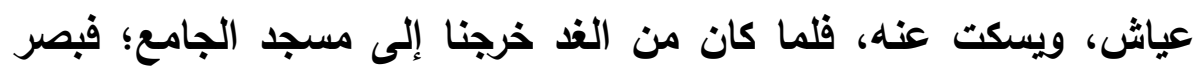

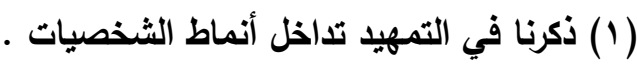

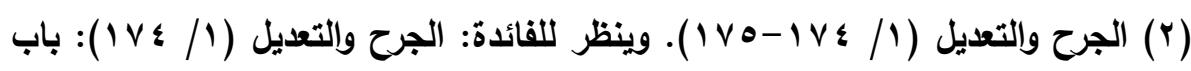
ما ذكر من حرص شعبة على طلب العلم.

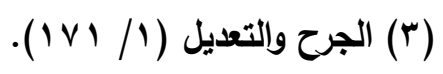


بنا، فنادانا فقال: يا أبا معاوية، نظرت فيما كلمتموني فوجدت لا يسعني

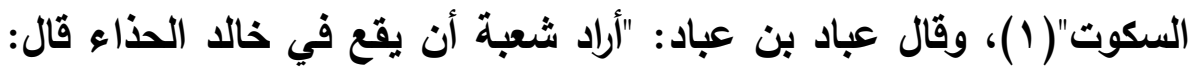

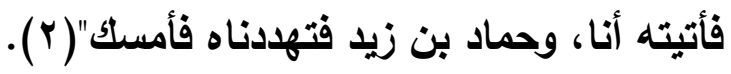

وقد يعترض معترض بأنه لم يلتزم بالثورى، والجواب واضح، وهو أنه تثثاور

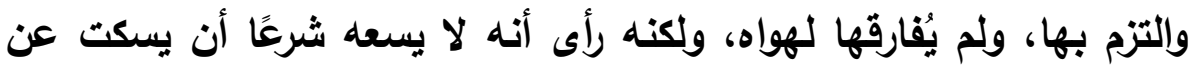

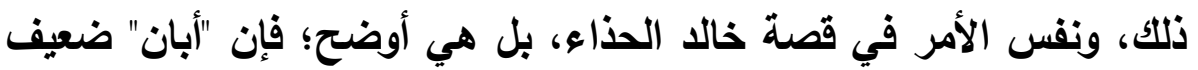

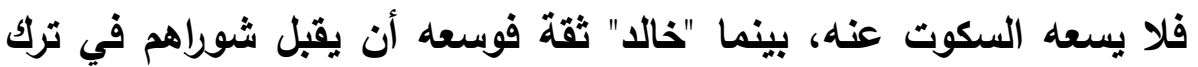

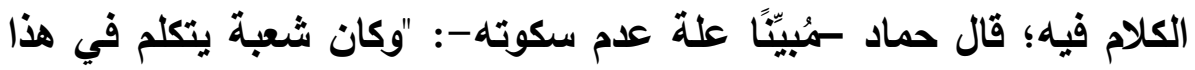

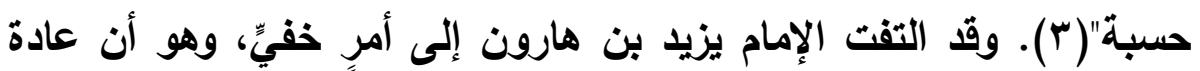
الله هتك أستار من يفضح الناس، فلولا حُسن قصد شعبة وصدق نئ نيته

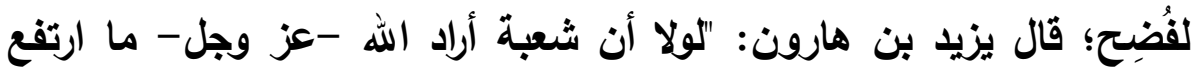

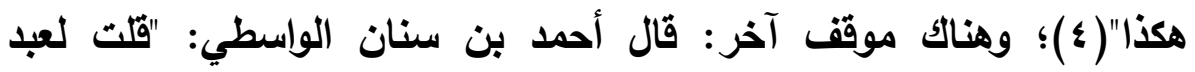
الرحمن بن مهذي: لم تركت حديث حكم جبير؟ فقال: حدثي يحيى القطان،

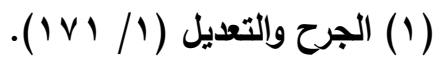

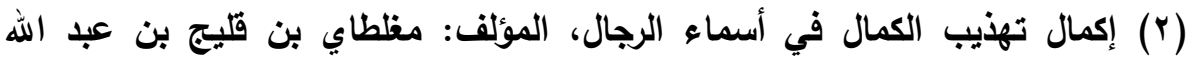

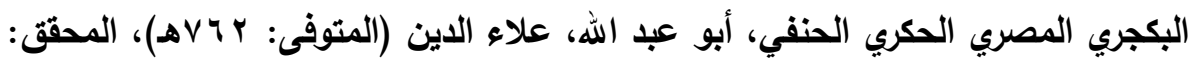

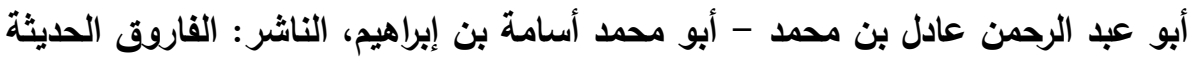

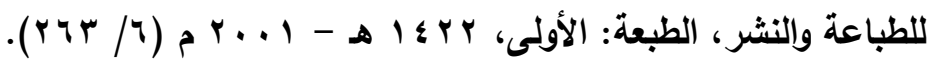

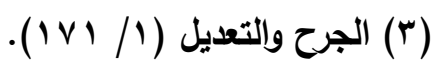

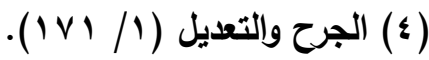


قال سألت شعبة عن حديث من حديث حكيم بن جبير فقال: أخاف النار. قال

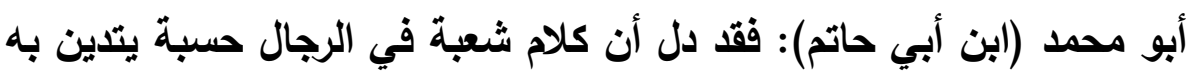

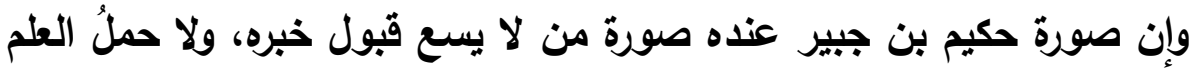

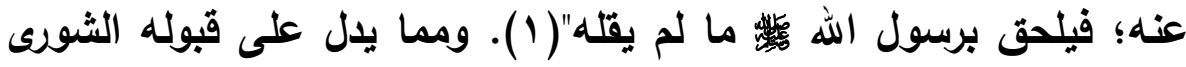
وعدم انغلاقه أنه غيَّر مذهبه؛ عن يزيد بن زريع، قال: قلم علينا شعبة

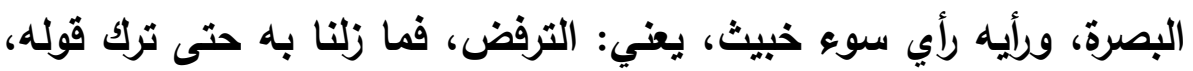

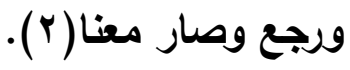

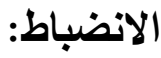

حيث كان له أوراده يراجع فيها أحاديث الرواة؛ قال بكر بن بكار : "صلى شعبة الغداة فسكت حتى طال ذلك، ثم أقبل علي فقال: ترون أني كنت أسبح؟ إنما

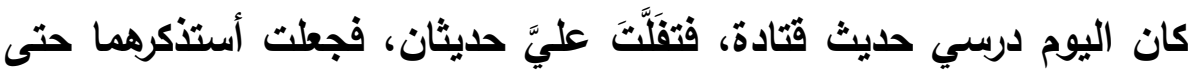

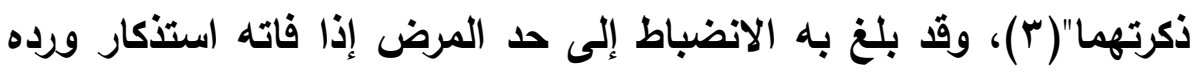

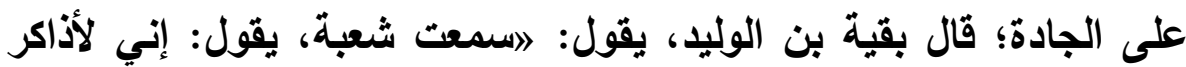

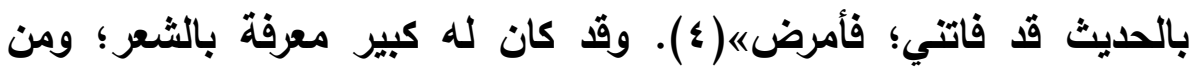

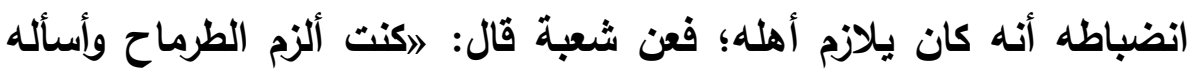

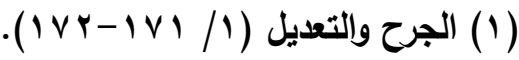

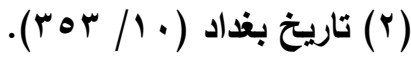

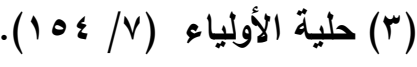

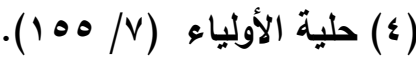


عن الشعر)(1)؛ وقد أتقته حتى شُهِه له؛ قال الأصمعي: 》لم نر أحدًا قط

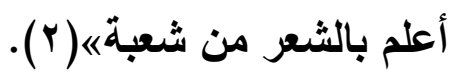

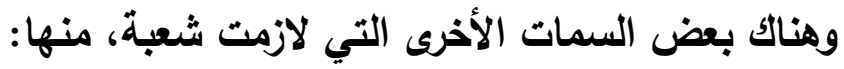

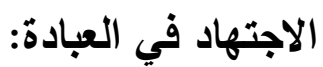

كان يجته حتى لا يكاد يلحقه أحد؛ قال أبو بكر البكراوي، قال: 》ما رأيت أعبد لله من شعبة، لقد عبد الله حتى جف جلده على عظمه، ليس بينهما

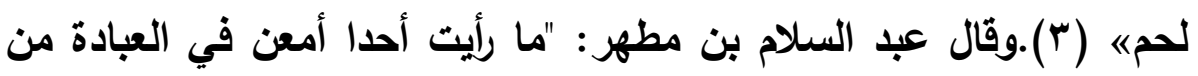

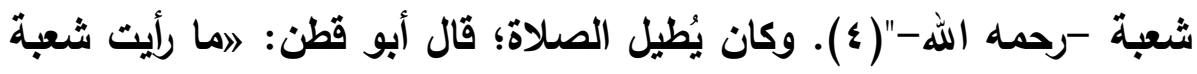

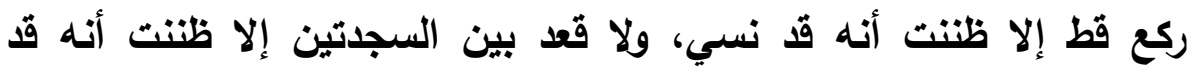
نسيه(0). وكان يصوم الدهر؛ قال عمر بن هارون: „كان شعبة يصوم

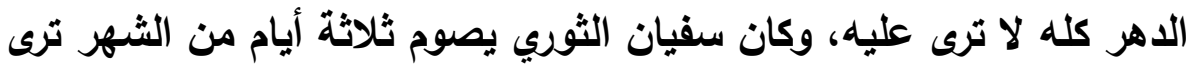

عليه «(7).

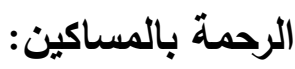

قال النضر بن شميل، قال: اها رأيت أرحم لمسكين من شعبة، إذا رأى

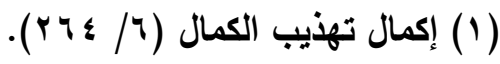

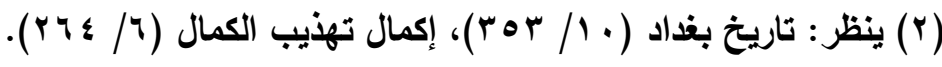

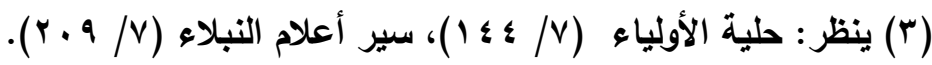

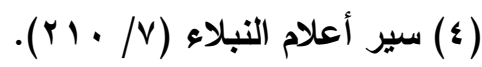

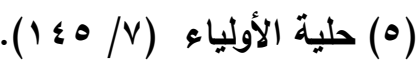

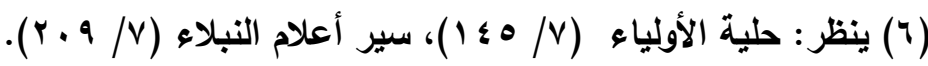


المسكين لا يزال ينظر إليه حتى يتغيب عن وجهه《(1).

قال مسلم بن إبراهيم: كان شعبة إذا قام سائل في مجلسه، لا يحدث حتى يُعطى أو يضمن له(Y). وقال حجاب: "ركب شعبة حمارا له، فلقيه سليمان بن المغيرة، فشكى إليه، فقال له شعبة: اوالله لا أملك إلا هذا الحمار، ثم نزل عنه، ودفعه إليه" (ب).وعن عمرو بن علي، قال: سمعت أبا داود الطيالسي، يقول: " كنا عند شعبة، فجاء سليمان بن المغيرة يبكي، فقال لله شعبة: ما يبكيك يا أبا سعيد؟ قال: مات حماري وذهبت مني الجمعة، وذهبت حوائجي قال: فبكم أخذته؟ قال: بثلاثة دنانير، قال: فعندي ثلاثنة دنانير، والله ما أملك غيرها يا غلام، هات تثلك الصرة، فإذا فيها ثثلاثة دنانير، فدفعها إليه

$$
\text { وقال: اشتر بها حمارا، ولا تبك"( ع). }
$$

كان - رحمه الله - موصوفًا بسخاء النفس؛ قال أبو قطن: \كان ثياب شعبة لونها لون التراب، وكان كثير الصلاة، كثير الصيام، سخي النفس《(•).

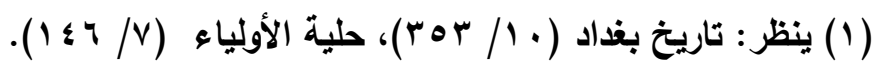

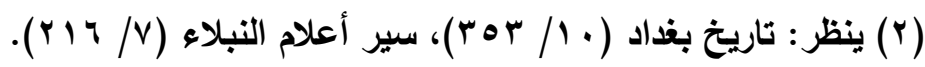

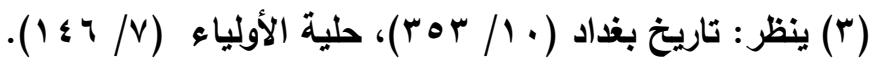

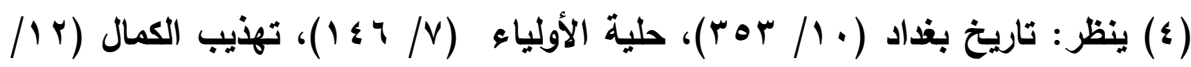


ولذلك بوب ابن أبي حاتم: باب ما ذكر من طهارة خلق شعبة

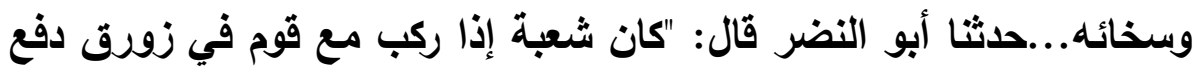
كرى الزورق عن كلهم"( ). وعن محمد بن عروة، قال: (اسمعت أصحابنا، يقولون: وهب المهدي لشعبة ثلاثين ألف درهم فقسمها، وأقطعه ألف جريب لفي

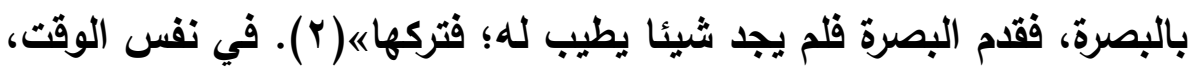
كان أخواه يُنفقان عليه؛ لشغفه غير المسبوق بالبحث، والسفر في الطلب، وكان ينهى عن ذلك؛ ويقول لأصحاب الحديث: ويلكم! الزموا السوق، فإنما

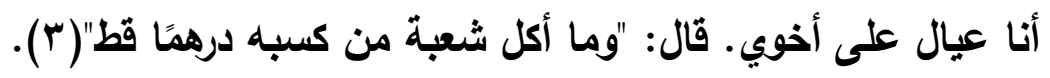
فهذه السمات قد لا تكون معتادة في الثخصيات اليقظة، وإنَّما في الثخصية المقبولية مثلًا، ولكن حمله عليها ما أقبل عليه من دراسة الحديث؛ قال

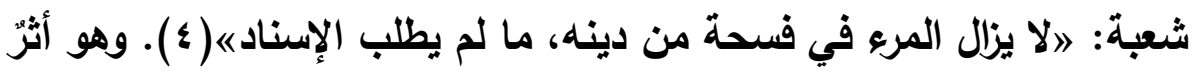

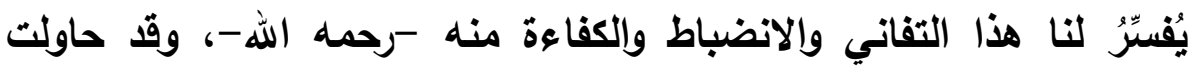

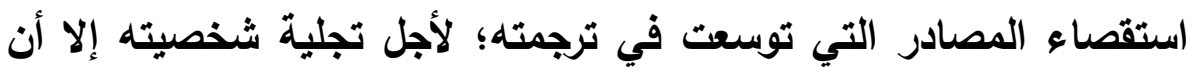

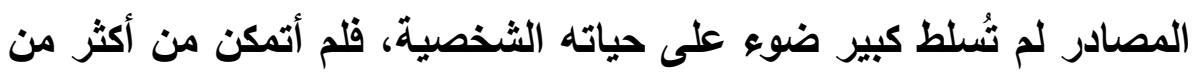
هذا. والله أعلم.

\section{$\operatorname{sen} \Delta \cos$}

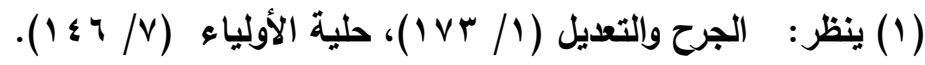

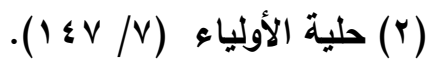

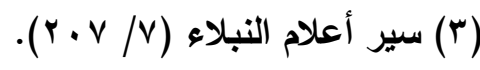

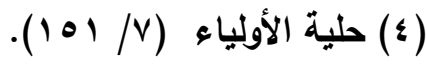




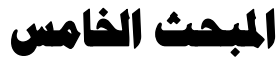

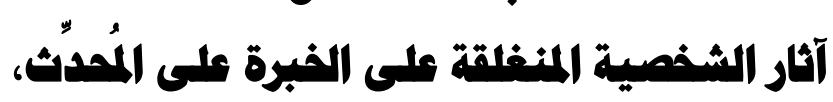

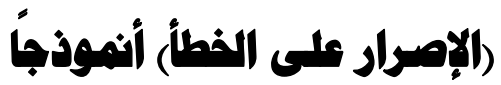

\section{| أولاً: تمريف الخطأ والإهرار :}

(الْخَطَأُ): مههوز بفتحتين ضِدُّ الصََّوَابِ، ويقصر ويمدّ وهو اسم من "أَخْطَاَ"

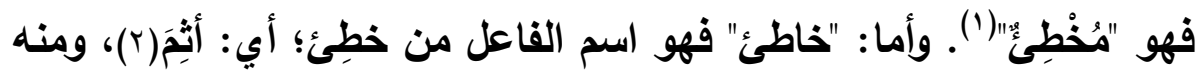

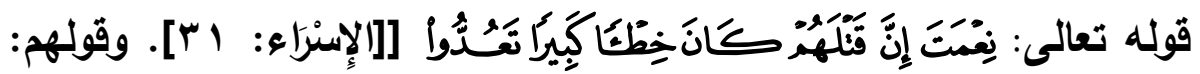

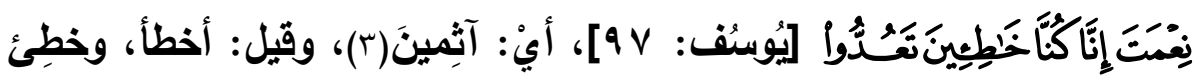

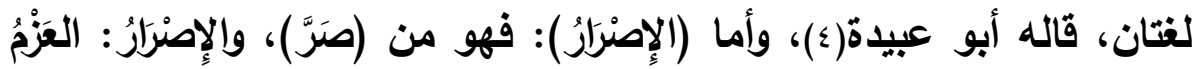

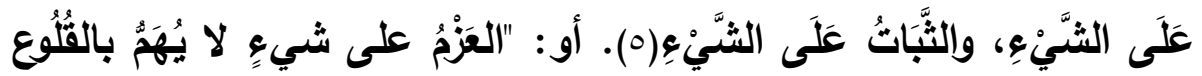

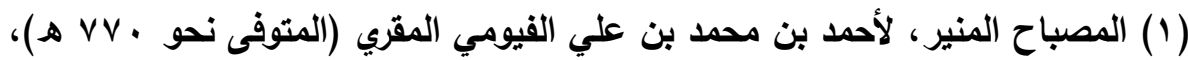

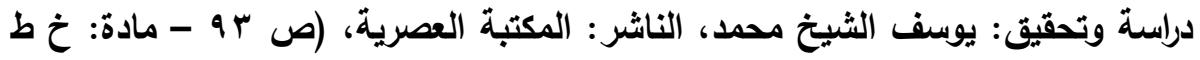

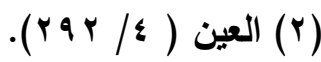

$$
\begin{aligned}
& .(r \cdot V / V)(r) \\
& \text { ( ) ( ) تهذيب اللغة (r.V/V) }
\end{aligned}
$$

(•) مقاييس اللفة، لأبي الحسين أحمد بن فارس بن زكرياء القزويني الرازي، (المتوفى:

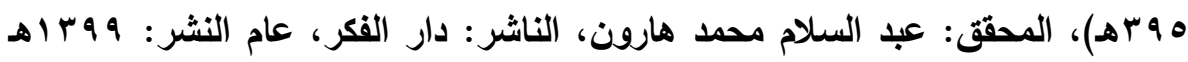

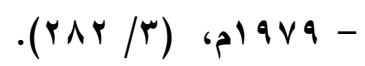


عنه"().؛ والمعنى المركب: "الإصرار على الخطأ" ظاهر، وهو : أن يثبت على

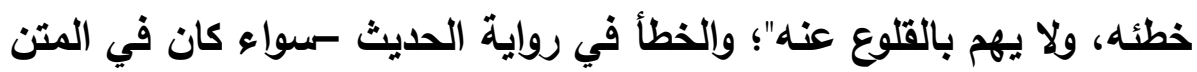
أو السند- يضر براوي الحديث أيما ضرر، فالراوي تدرك رتبته في الحديث في فئه

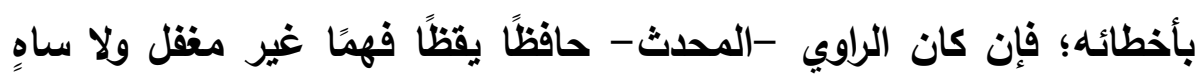

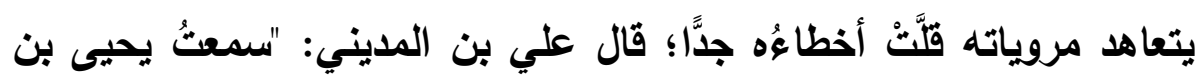

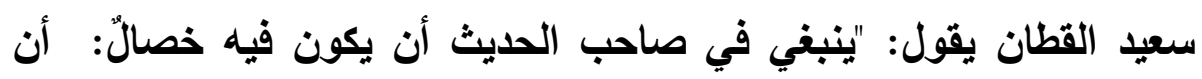

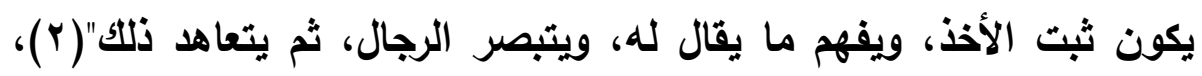
وإذا لم يتثبت ويتعاهد مروياته، كثُر خطؤه. ه ثانياً: أقوال العلمهاء فيمن يفطئ وينبه على خطأه فلا يرجع وبيان وهذا البحث ها هنا يتعلق بسمة من سمات بعض الرواة وهي: أنه يخطئ

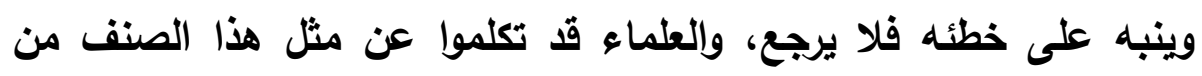

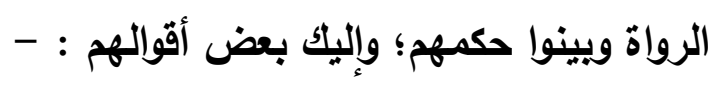
قال ابن مهدي : "قلت - أو: قيل لثعبة (ت . 17 هـ): من الذي يُترك

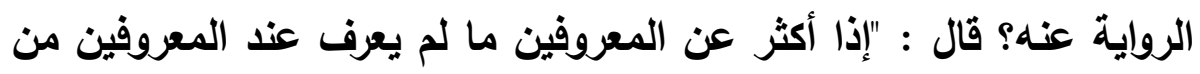

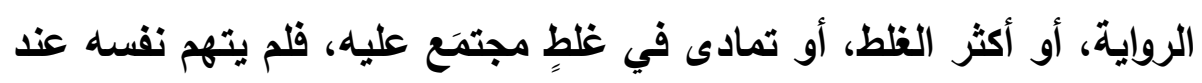

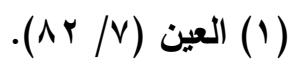

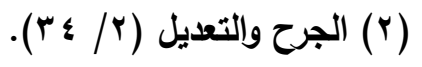


(جتماعهم على خلافَه،أو يتهم بكذب، فأمّا سوى من وصفت فاروِ عنهم"(')،

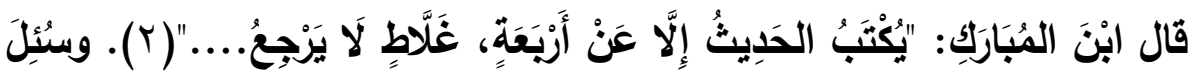

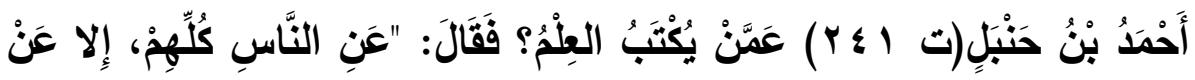

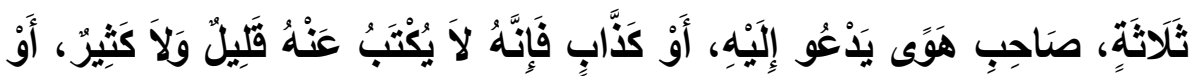

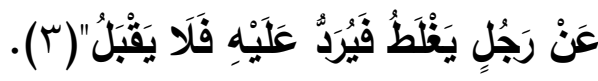
ومما سبقَ يُعلم أن ليس من شرط الثقة أنه لا يغلط، فإنه معلوم بداهةً أن الصدوق، بل الثقة الحافظ يهم، ويخطئ، ويخالف: قال الحافظ الأهبي -

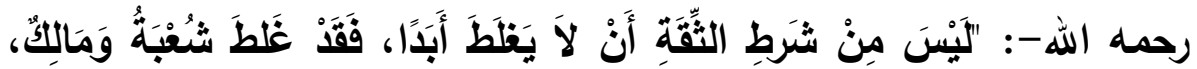

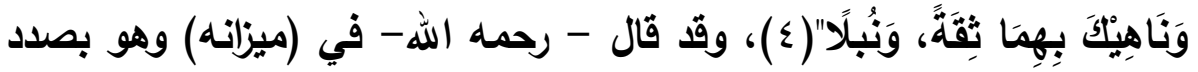
الرد على العقيلي: "ثم ما كل أحد فيه بدعة، أو له هفوة أو ذنوب يقدح فيه بما يوهن حديثه، ولا مِن شرط الثقة أن يكون معصوما من الخطايا والخطأ،

(1) أخرجه العقيلي بسنده في مقدمة كتابه: (الضعفاء / / ب ا))، المحقق: قسم = =

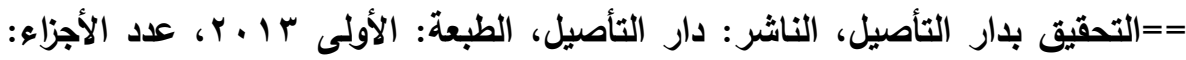

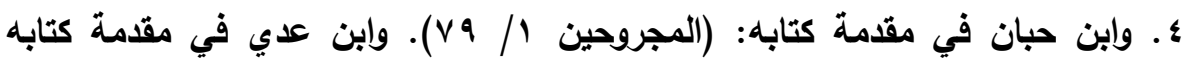

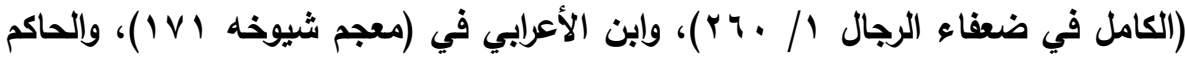

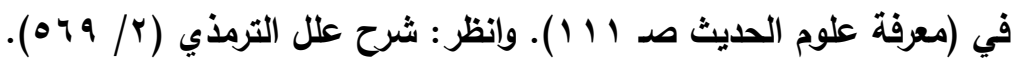

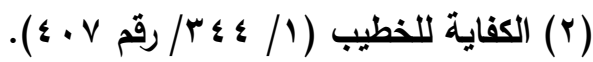

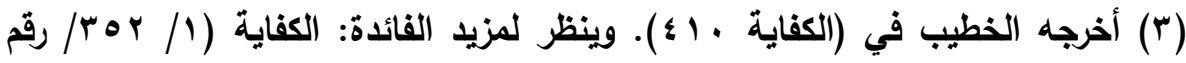
$6(\leqslant r \mu$

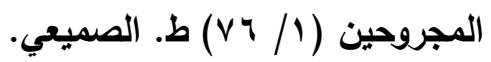

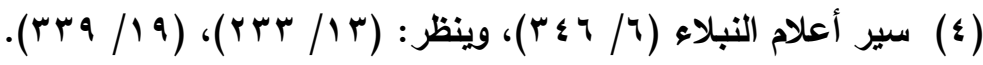


بل فائدة ذكرنا كثيرًا من الثقات الذين فيهم أدنى بدعة أو لهم أوهام يسيرة في

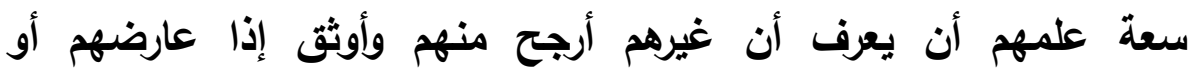
خالفهم"( ()، وإنما مرادنا من هذا البحث بيان أن من الواجب على من أخطم أخطأ ويُيِّنَ له الخطأ أن يرجع إلى الصواب، ورانيا هن لها يتعنت، ولا يتكبر. وإذا تذوق المشتغل بالصناعة الحديثية حديث من يُصِرٌ على الخطأ بانَ له

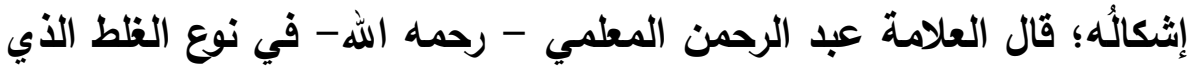
إذا أصرَّ عليه الراوي أضرَّ به: "أقول: الخطأ الذي يضرُ الراوي الإصرارَ عليه

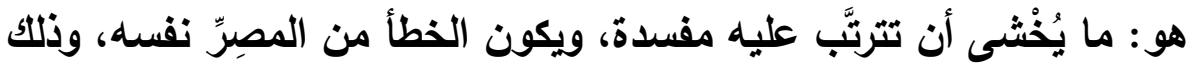

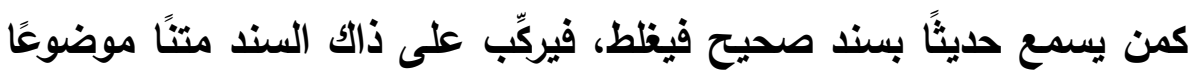

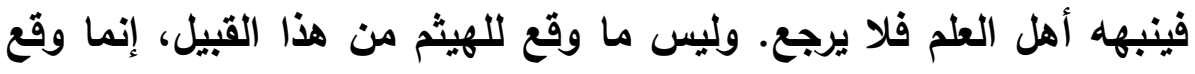

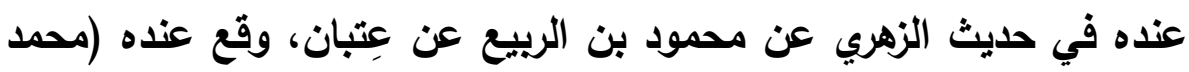

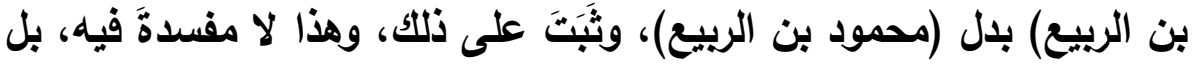

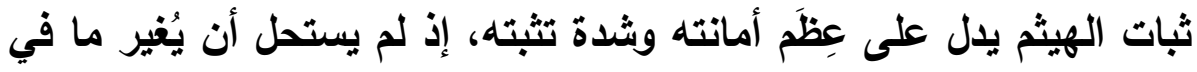

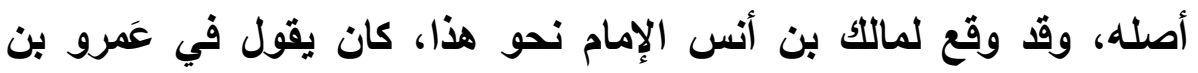

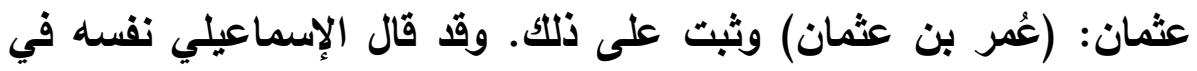

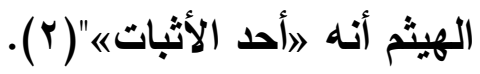

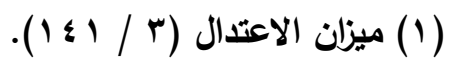
(Y) التنكيل لما ورد في تأنيب الكوثري من الأباطيل، المطبوع ضمن: آنَّار الثيخ العَلّامَة

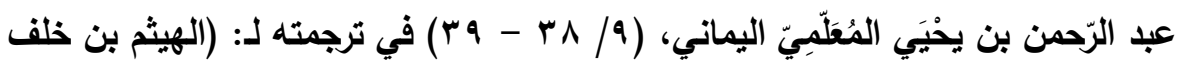

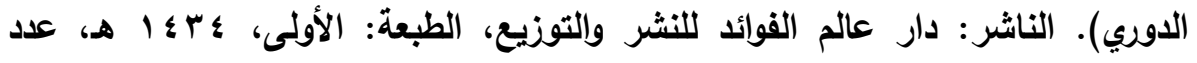


وقبل أن نبأ في دراسة السمة نذكر موقفًا جليلاً لعالم ثبت رجع مع التببيه؛

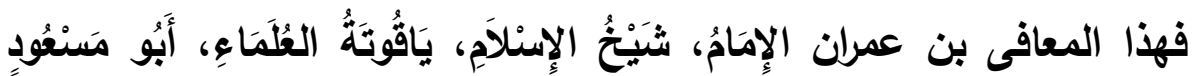

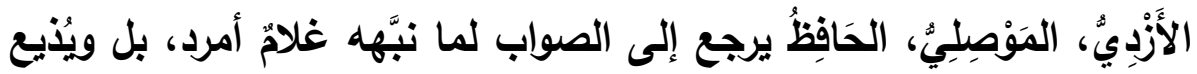

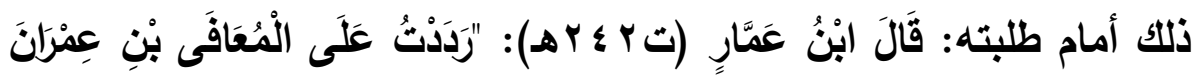

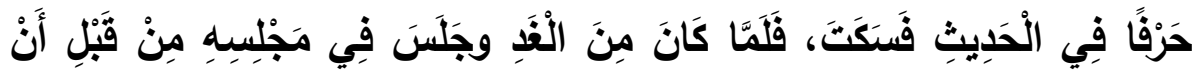

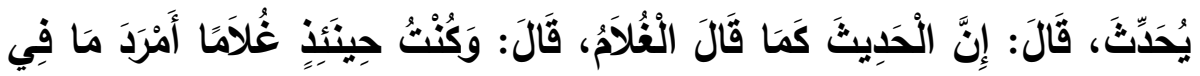

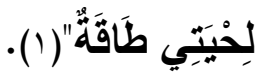

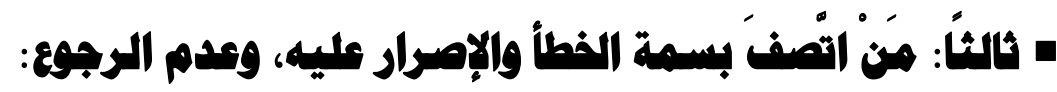

وممن اتَّفف بهذه الصفة من العلماء:

أبو الحسن علي بن عاصم بن صهيب الواسطي، مولى قريبة بنت

محمد بن أبي بكر الصديق رضي الله عنه. وسنفرده بالدراسة. سفيان بن وكيع بن الجراح، الرُوَّأسيِ، الكُوفِي.

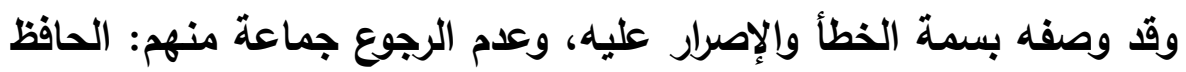

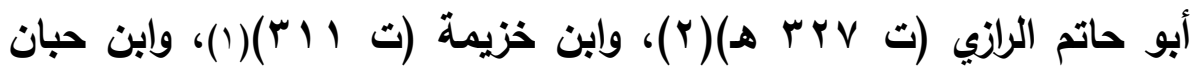

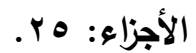

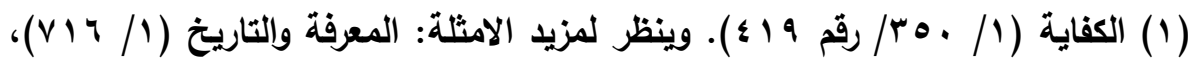

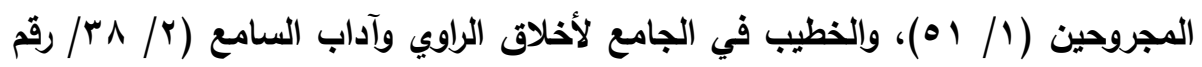

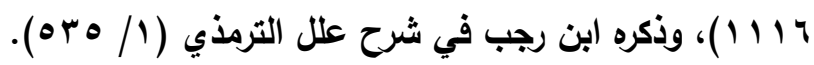

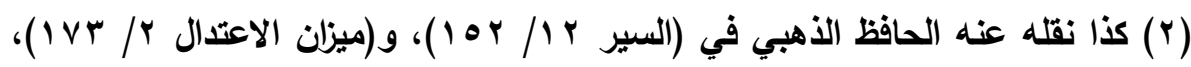

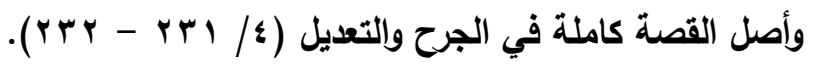




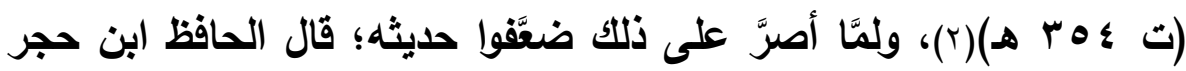

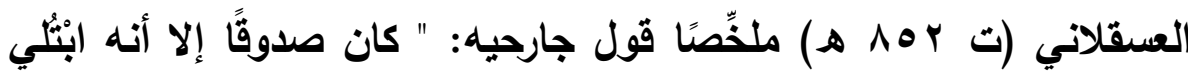

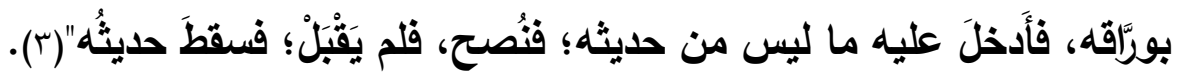

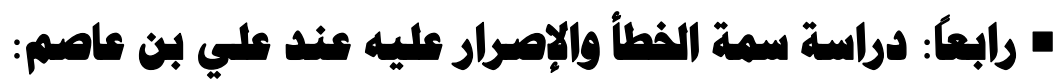
وصفه بسمة الخطأ والإصرار عليه، وعدم الرجوع جماعة كثيرة، منهم الإمام أبو الحسن علي بن عبد الله بن المديني (ت ع ب هـ)؛ حيث قال: "كان كثير الغلط، وكان إذا غلط فرد عليه لم يرجع"( ع). ومنهم أبو خيثمة زهير بن حرب

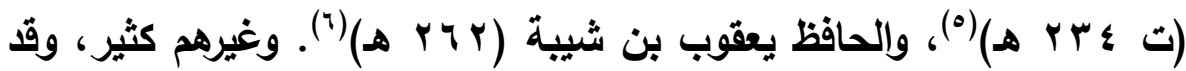
لخص كلامهم الحافظ ابن حجر (10Y هـ)، حيث قال: "صدوق يخطئ ويصِرٌ "(v) ه خامساك: نهاذه تدل على اتمافه بسمة (الخطأ والإهراد عليه، وعدم الرجم:ع): (1)

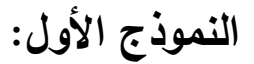

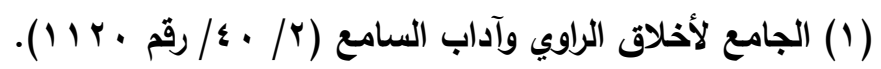

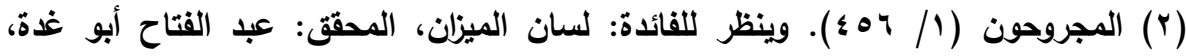

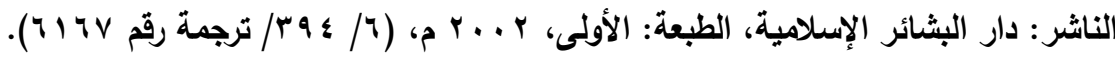

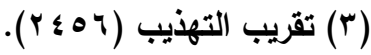

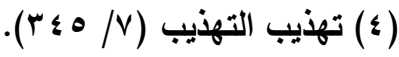

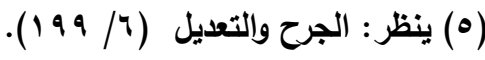

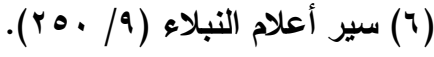

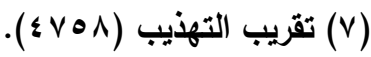




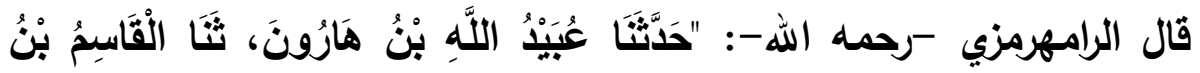

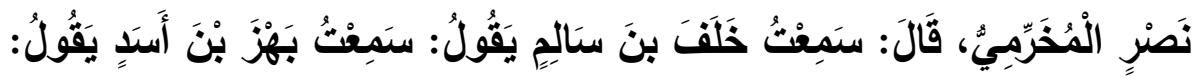

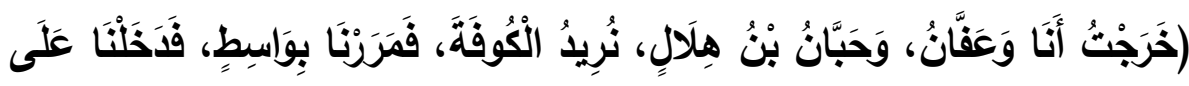

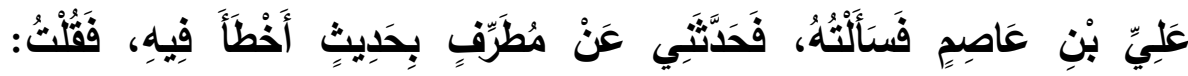

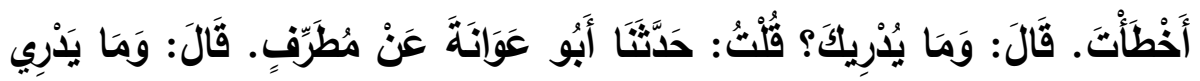

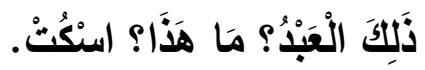

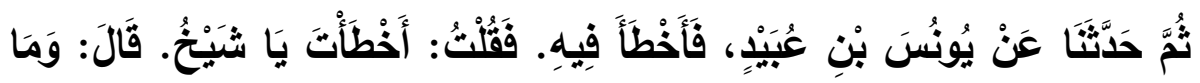

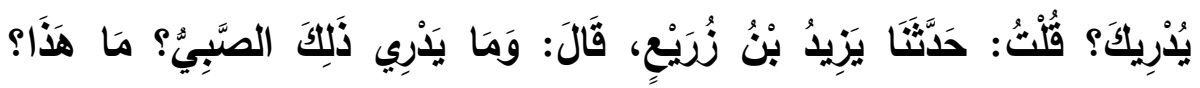

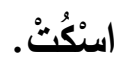

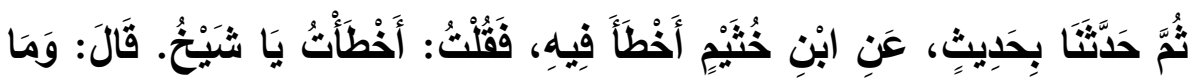

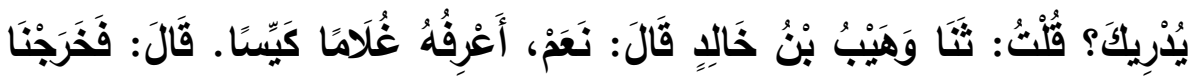

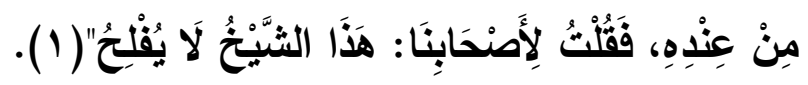

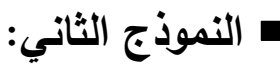

قال ابن أبي حاتم في كتاب 》العلله: "وسألتُ أَبَي وَأَبَا زُرْعَةَ عَنْ حديثٍ رَوَاهُ

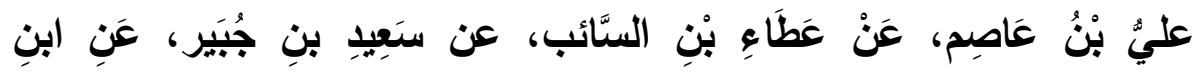

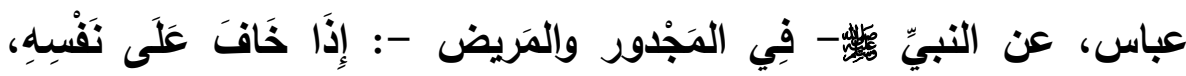

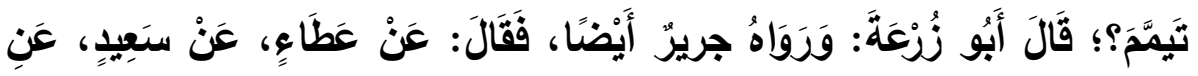

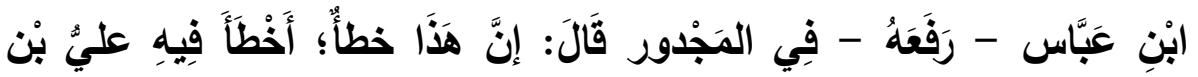

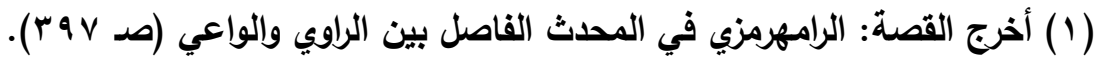

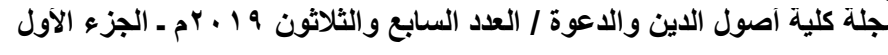


عَاصِم.

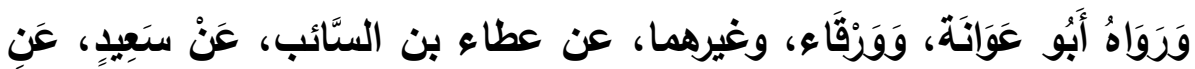

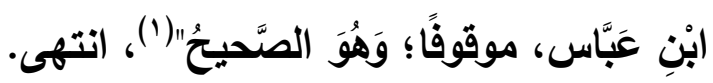

والواضح أن عليَّ بن عاصم جعل الحديث من قول رسول الله

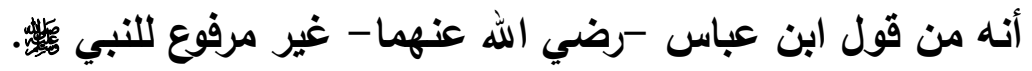

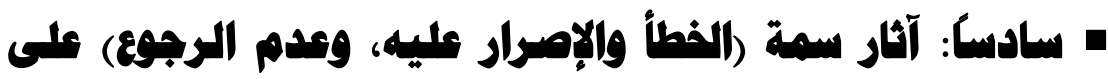 آراء علي بن عاهم في الأماديث النبروية:}

ترتبَّبَ على كون علي بن عاصم يُخطئُ ويصرُ على الخطأ ولا يتراجع، نقدُ للعلماء؛ وكانت من الكلمات المنصفة في حقِّ علي بن عاصم كلمة الإمام وكيع بن الجراح - رحمه الله تعالى- التي نقلها عنه الإمام أحمد بن حنبل،

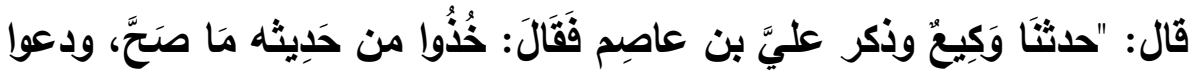

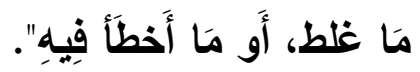
وقد أخذ الإمام أحمد - رحمه الله تعالى - بهذه النصيحة، فكان يروي عن علي بن عاصم في 》المسنده ويستأنس بكلام وكيع؛ قَالَ عبد الله بن

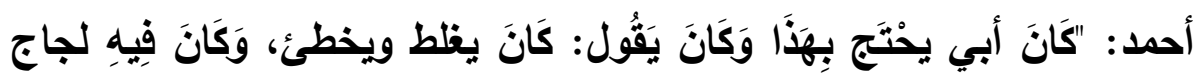

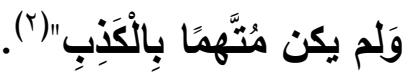

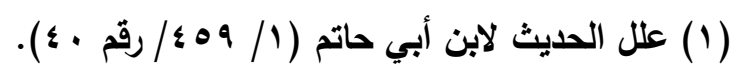

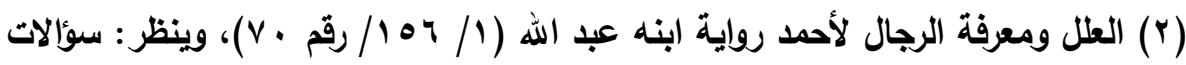

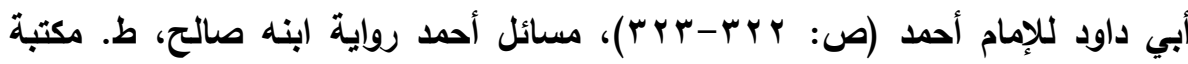


وقال أبو زرعة الرازي: "وحدثا محمد بن يحيى النيسابوري قال: قلتُ لأحمد بن حنبل في علي بن عاصم، وذكرتُ له خطأه، فقال لي أحمد: "كان حماد بن سلمة يخطئ، -وأومأ أحمد بيده- خطاً كثيرًا، ولم ير بالرواية عنه بأستًا،

$$
\text { وحدثنا محمد بن يحيى( ) عنه"(r). }
$$

والإمام أحمد - رحمه الله تعالى - في هذا النص؛ ق كان حماد بن سلمة يخطئ ويظلط كثيرًا هل تركنا الرواية عنه؟! وهل قال العلماء: إنه لا يجوز الرواية عنه؟! بالطبع لا. ولكن كما نأخذ من حماد بن سلمة ما لم يثبث أنه أخطأ فيه، ونترك لله ما ثبت خطؤه فيه، كذلك العمل مع علي بن عاصم. وق استفدنا فائدة - أيضًا- من كلام أبي زرعة الرازي - رحمه الله- أن الأهلي (محمد بن يحيى) كان يحدث عنه، ولم يترك الرواية عنه، وهو إمامٌ كبيزٌ جليل القدر. فخلاصة قول أحمد فيه أنه يقبله إلا ما عُرِف أنه أخطأ فيه مما أصر على الخطأ. وقد وثَّقَه غير واحد، منهم: العجلي(ץ)، والحاكم(؟).

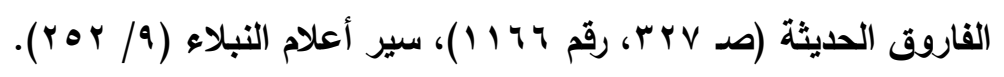
(1) هو الإمام الحافظ الثهير محمد بن يحيى الأهلي.

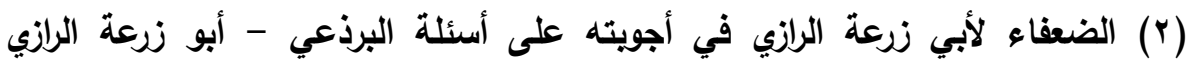

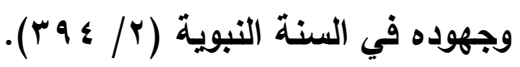

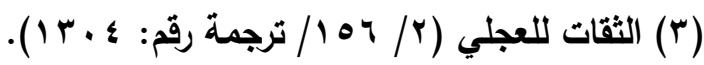

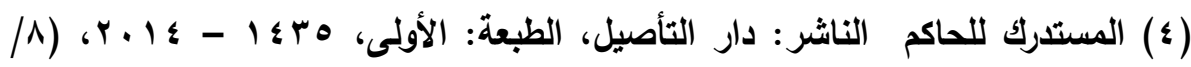

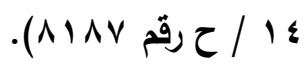


فالراجح -إن شاء الله- في شأن علي بن عاصم أنه صدوق وليس بكذاب، يخطئ، فيُترك من حديثه ما أخطأ فيه كما نقلناه عن أحمد، ومن أهل العلم من يقبله في المتابعات لا فيما تفرد به كالحافظ ابن حبان (1).

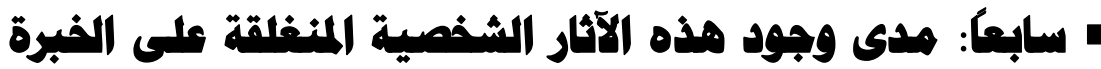 في هياة علي بن عاصم عموماً:} لا يخفى على الناظر ظهور آثار الشخصية المنغلقة على الخبرة ذات القيم التسلطية، في شخصية علي بن عاصم. وأوجه هذه الشخصية هي ضد سمات الشخصية المنقتحة على الخبرة التي وُسِيمت ب: "الخيال، المشاعر، الجماليات، الفضولية، البحث عن الجديد، التقبل، فتكون سمات المنغلقة على الخبرة بالعكس: "الواقعية دون الخيال، ضعف الحس الجمالي، القتاعة بالقديم وعدم التقكير في تصحيح، عدم تقبل الآخرين، وسمَّاها بعض الباحثين: " حازم، متحفظ "، وزادوا "يتجاهل

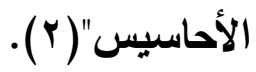
فأما القتاعة بالقديم؛ فيوضحه إصراره على الخطأ، كما فصلنَّا في المبحث السابق ونُلخِص صورة منها هي التي تسببت في جرحه؛ فعن يعقوب بن سفيان،

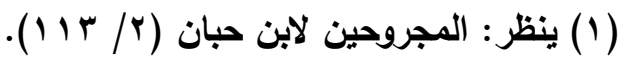

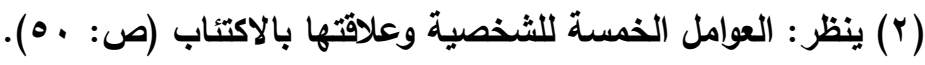




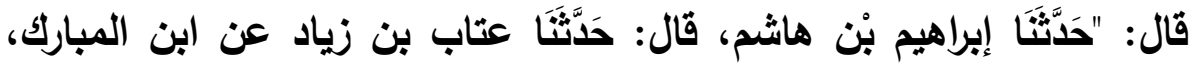

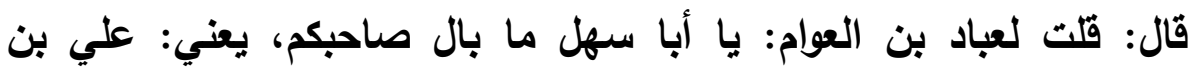

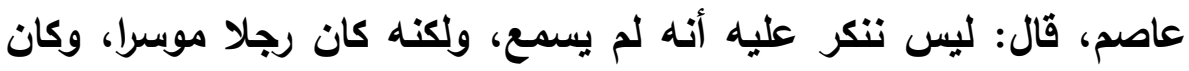

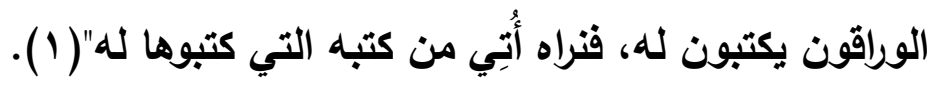
ومما يُقرّر قناعته بالقديم ما وُصِف بهه من شدة التوقي: فقد وصفه به

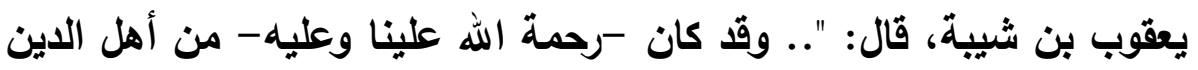

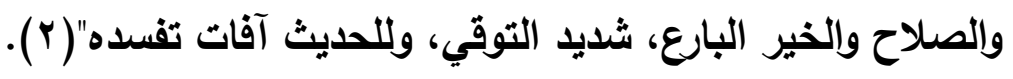
وأما عدم تقبل الآخرين؛ فهو واضح في شخصيته؛ فعن علي بن شعيب،

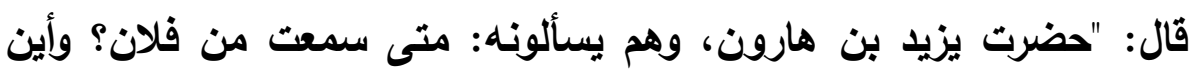

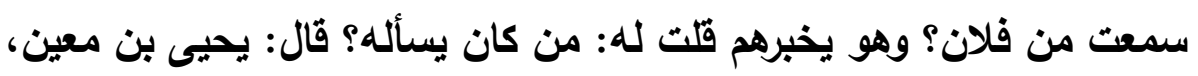

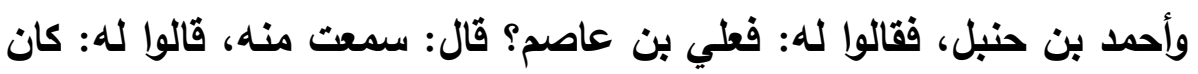

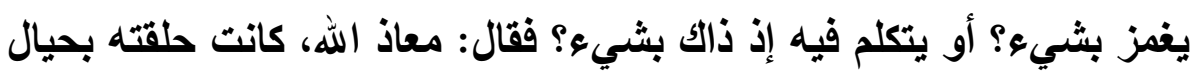
حلقة هشيم، ولكنه كان لا يجالسهم، وكتب، ولم يجالس، فوقع في كتبه

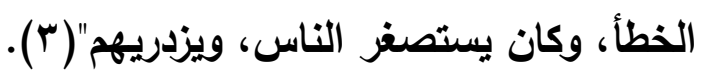
وهذه قصة تُجَلِّي ذلك؛ فعن عفان، قال: "قدمت أنا ويهز واسطًا، فذخلنا على

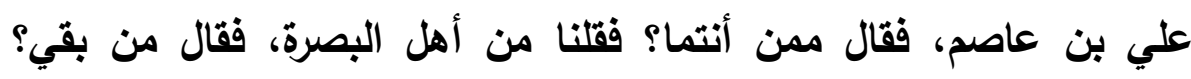

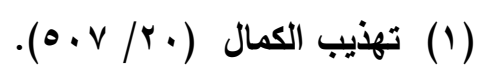

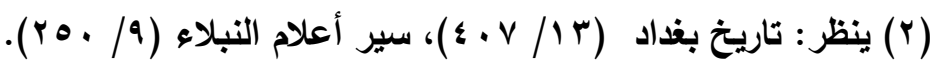

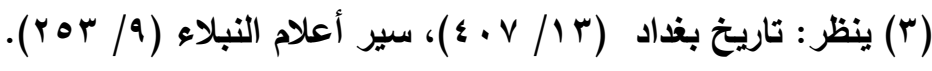


فجعنا نذكر حماد بن زيد، ومشايخ البصريين، ولا نذكر له إنسانًا إلا

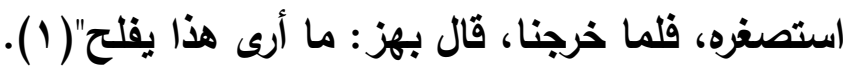

إلا أنه قد يُطلب العذر لعلي بن عاصم في هذا بأن جملة من المُحدِّثين كانوا يتتبعون السلاطين، فكان يزدريهم لذلك؛ لأن العالم لا ينبغي أن يقف بياب

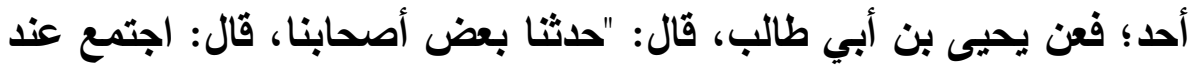

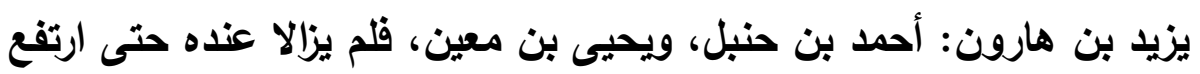

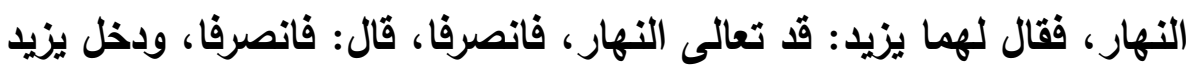

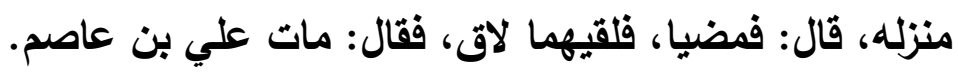
قال: فقال أحم: ارجع بنا حتى نعزي أبا خالد، قال: فرجعنا، فدق أحمد

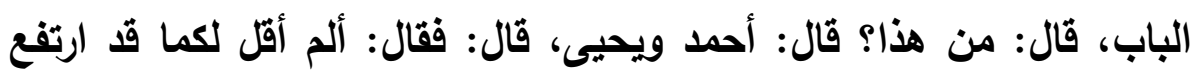

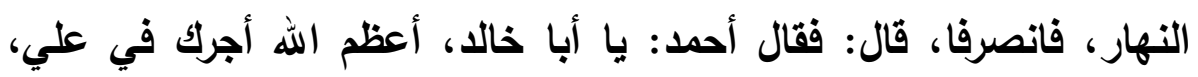

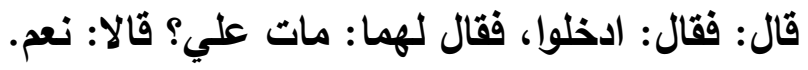
قال: إنا لله وإنا إليه راجعون، ثم دفع باكيًا ساعة، ثم قال: رحمك الله يا أبا

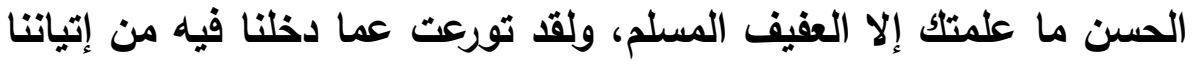

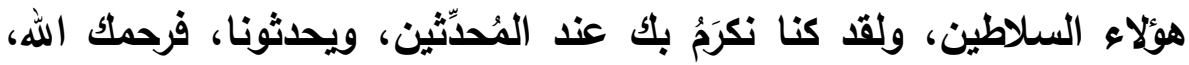
فإن مصيبتك عظيمة. أو كما قال، فقال له يحيى: يا أبا خالد، إلا إنه تلاج في تلك الأحاديث التي غلط فيها، قال: ففضب يزيد، ثم قال: ويحك يا يحيى! أتقول: إن عليًَا أقام

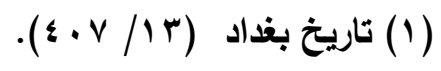


عليها، وهو يعلم أنها عنده خطأب والله لئن قّت ذاك لقد أثمت.

أو كما قال: تتوهم على علي أنه كان يقيم على ذلك؟! ويحك يا يحيى لا يكون خصمك يوم القيامة.

قال: فقال له أحمد: يا أبا خالد، قد والله نهيته عن ذلك فأبى علي، وقلت له: هات ما أخطأ علي ومات عليه، وما أخطأ شريك ومات عليه، فإن لـ يكن خطأ شريك أكثر من خطئه، وقا نصحته، وأرجو أن يقبل منك، فقال يزيد: اتق الله، ولا تلق الله بما تقول"( ).

والأي حملنا على هذا تأول موقفه من ازدراء الناس سمع السبب المذكور أنه كان معروفًا بالصلاح؛ فعن عبيد بن يعيش، قال: "رجعنا مع وكيع عشية مناية جمعة، وكان معنا ابن حنبل، وخلف، فكان وكيع يحدث خلفا، فقال له: من بقي عندكم؟ فنكر شيوخًا، وقال: عندنا علي بن عاصم؟ قال وكيع: فعلي بن عاصم ما زلنا نعرفه بالخير، قال خلف: إنه يغلط في أحاديث، قال: فدعوا الغلط، وخذوا الصحاح، فإنا ما زلنا نعرفه بالخير"(r). فثهادة وكيع وأحمد له دالة على فضله في الجملة.

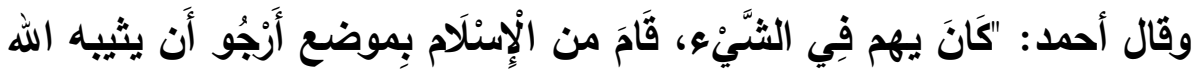

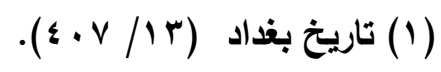

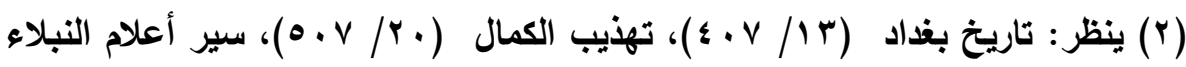
.$(r \circ 1 / 9)$ 


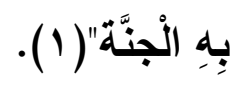

ومما يُستأنس به ما ذكره الخطيب عن موسى بن حماد، قال: لأيث سفيان الثوري في المنام في الجنة، يطير من نخلة إلى نخلة، ومن شجرة إلى شجرة، فقلت: يا أبا عبد الله، بم نلت هذا؟ قال: بالورع، بالورع، قلت: فما بال علي بن عاصم؟ قال: ذاك لا نكاد نراه إلا كما نرى الكوكب"(Y). وأما تجاهل الأحاسيس؛ فقد كان علي بن عاصم من ذوي الأحوال، والاتساع في الانيا، ولم يزل ينفق في طلب العلم، ويفضل على أهله قايمًا"(ب).

(1) سؤلات أبي داود للإمام أحمد بن حنبل في جرح الرواة وتعديلهم، أبو عبد الله أحمد

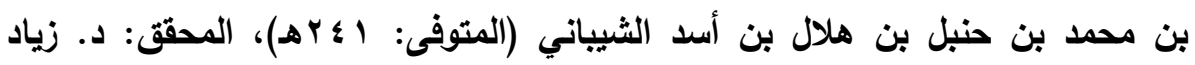

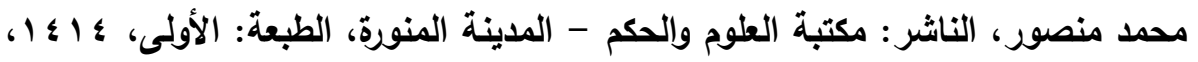

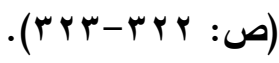

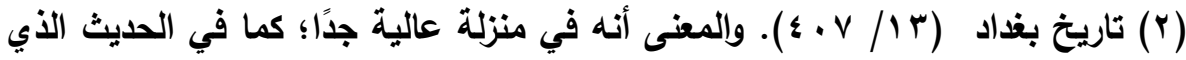

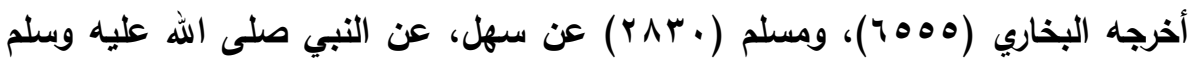

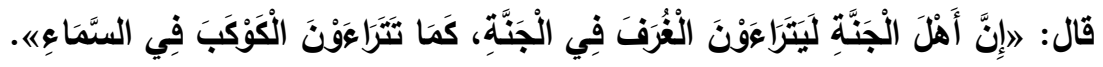

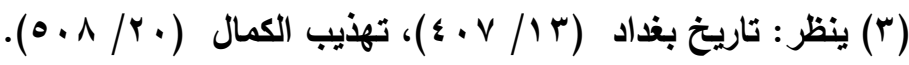




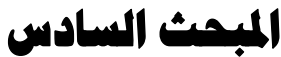

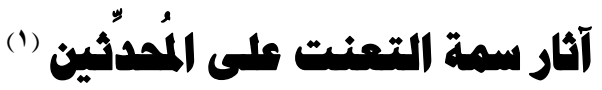

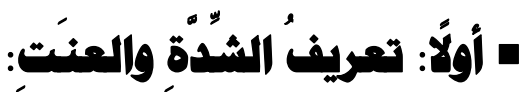

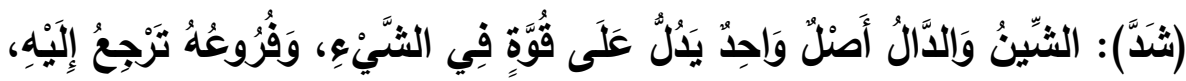

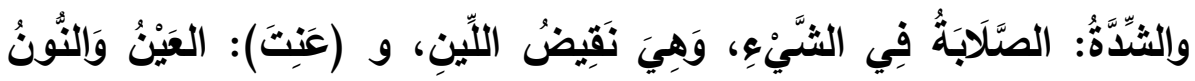

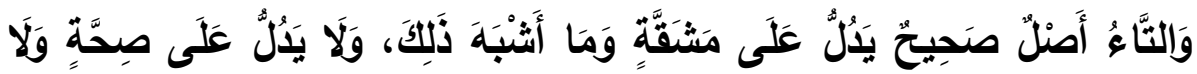

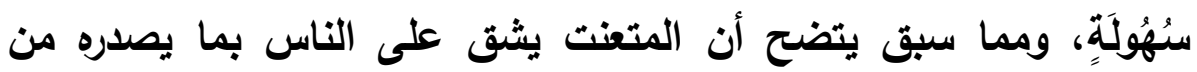
أحكامٍ فيها تعفف وشدة؛؛ بسبب شِدِته وصلابته (ץ). ه ثانياً: العلماء الذين اتصفوا بسمة التعنت: وممن اتصف بهذه الصفة يحيى بن سعيد بن فروخ القطان، قال ابن دقيق

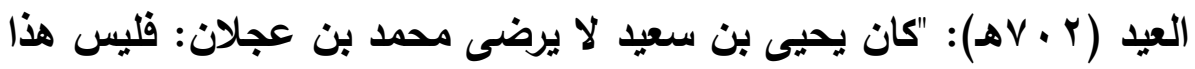

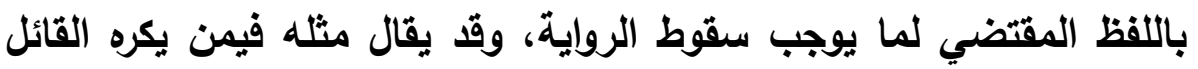

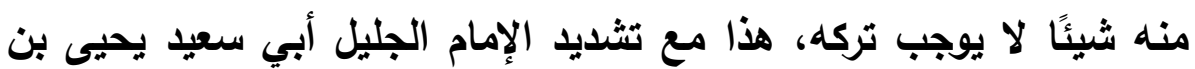

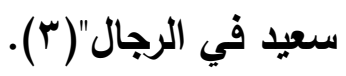

(1) لم يصنف البحث التعنت في شخصية بعينها سوإن كانت أقرب إلى الانظوائية- لكن

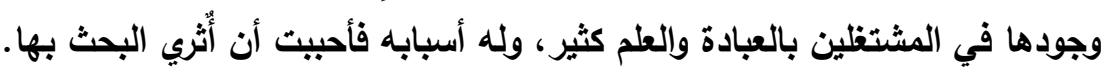

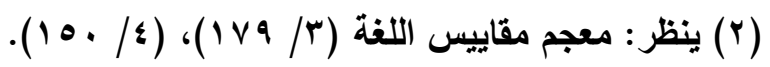

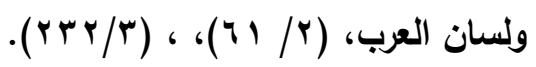
(r) ينظر : شرح الإلمام بأحاديث الأحكام، تقي الدين أبو الفتح محمد بن علي بن == $|\wedge|$ جلمة كلية اصول الدين والدعوة / العدد السابع و الثّلاثون 9 ا ـ بم ـ الجزء الاول 


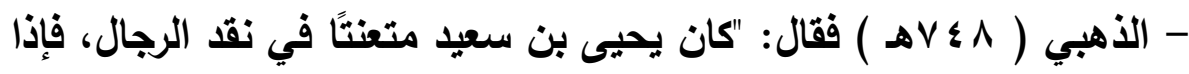

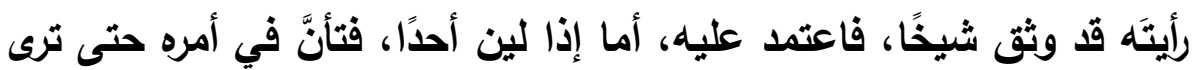
قول غيره فيه، فقد ليَّن مثل إسرائيل وهمام، وجماعة"( (1).

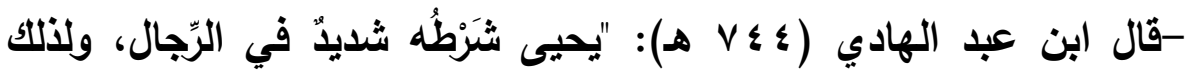
قال: لو لم أرو إلا عمَّن أرضى ما رويت إلا عن خمسة" (r). ه ثالثاً: نماذه تدل على التمانه بسمة (التعند):

قال يحيى بن معين: قال يحيى بن سعيد: "الو لم أرو إلا عن كل من أرضي -أو كلمة نحوها- ما رويت إلا عن خمسة"(r)، وقدمنا كلام الأهبي في

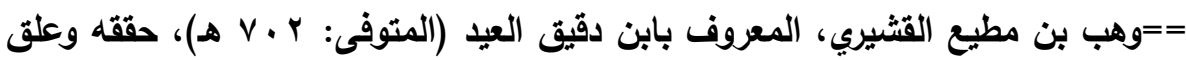
عليه وخرج أحاديثه: محمد خلوف العبد الله، الناشر: دار النوادر، سوريا، الطبعة: الثانية، .

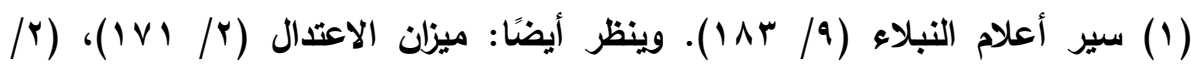
$.0 \vee r / r)$ ) ( $)$ ( 00

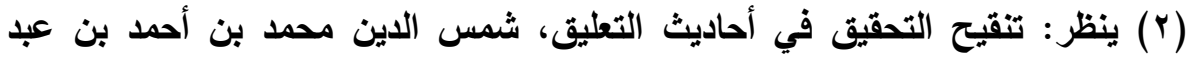
الهادي الحنبلي (المتوفى: ؟ ؟ V ه)، تحقيق: سامي بن محمد بن جاد الله وعبد العزيز

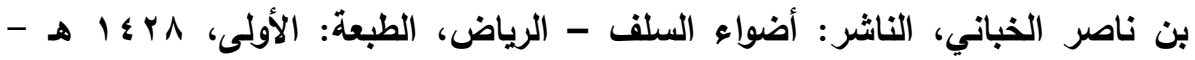

$$
\text { . r. }
$$

(r) ينظر : تاريخ ابن معين (رواية الدوري)، أبو زكريا يحيى بن معين بن عون بن زياد

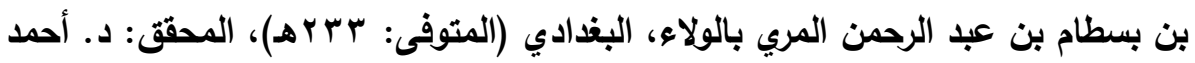

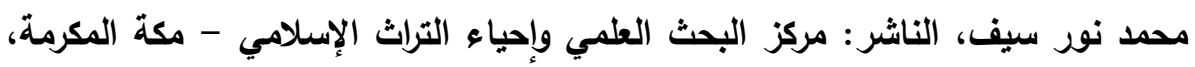

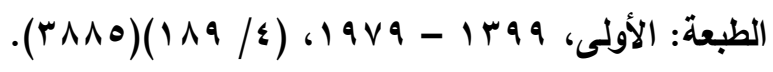


تلينينه جماعة من الثقات كإسرائيل وهمام. وممن ليَّنه ابن إسحاق، وسيتم مناقشة ذلك .

رابعاً: آثار سمة (الششدة والتعند) على آراء يميى القطان المديشئة:

أ - تحامله على محمد بن إسحاق بن يسار، ورفض العلماء لكلامه فيه: قال الحافظ (بن رجب في ترجمة (محمد بن إسحاق بن بسار صاحب السيرة)، بعد سرده لأقوال الأئمة في الثناء على ابن إسحاق: "وكان يحيى بن سعيد شديا الحمل عليه، وكان لا يحدث عنه، ذكره عنه الإمام أحمد، وقال: ما رأيتُ يحيى أسوأ رأيًا منه في محمد بن إسحاق، وليث، وهمام، لا يستطيع أحد أن يراجعه فيهم"( ) (1). توثيق العلماء لابن إسحاق:

ولم يلتفتِ العلماء إلى لأي يحيى في ابن إسحاق، بل أثنوا عليه، ووثَّقوه، ووصفوه بالصدق، وحسَّنوا حديثه؛ منهم ابن المديني وابن معين وابن حنبل وغيرهم كثير؛ قال الزهري: لا يزال بالمدينة علم جمٌٌ ما كان فيهم ابن إسحاق، وقال عاصم بن عمر بن قتادة: لا يزال في الناس علم ما عاش محمد بن إسحاق، وقال ابن البرقي: "لم أر أهل الحديث يختلفون في ثقته، وحسن

$$
\text { (1) شرح علل الترمذي (19/1 ؛ ). }
$$


حديثه، وروايته"(1)، ومما يدل على توثيقه إخراج الإمام مسلم لله عدة

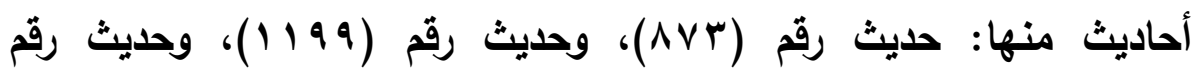

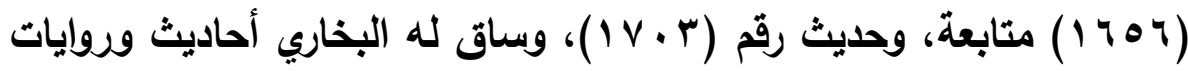

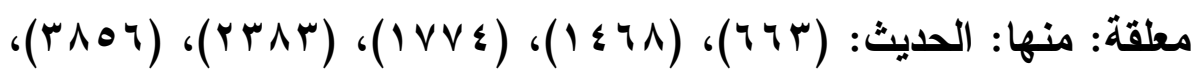

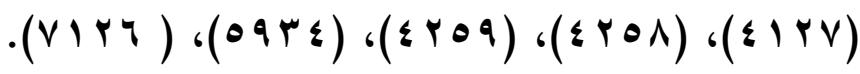

ب- تحامله على إسرائيل بن يونس بن أبى إسحاق السبيعي، ورفض العلماء J

قال ابن معين: "كان يحيى بن سعيد القطان لا يروي عن إسرائيل ولا شريك،

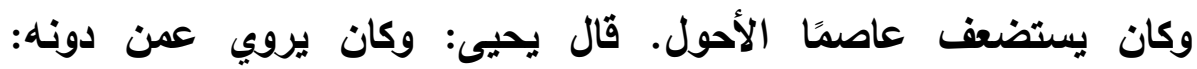

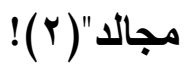

ولم يلتفت العلماء إلى رأي يحيى في إسرائيل:

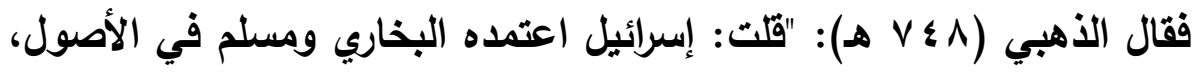

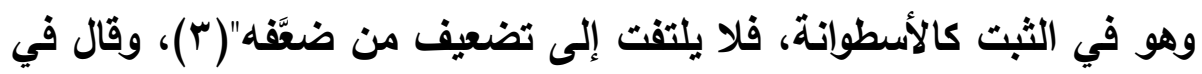
(السير): "ليس هو في التثبت كسفيان وشعبة، ولعله يقاريهما في حديث

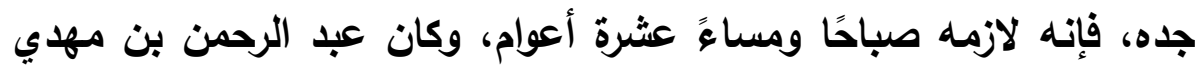

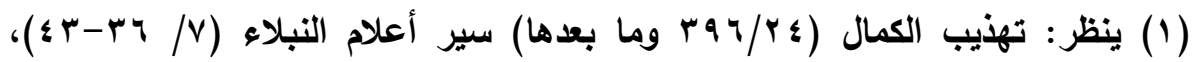

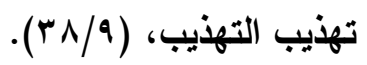

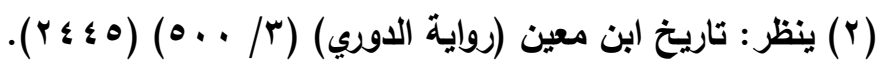

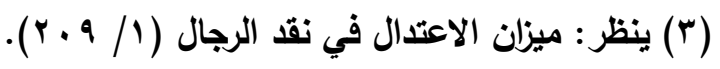


يروي عنه ويقويه، ولم يصنع يحيى بن سعيد شيئًا في تركه الرواية عنه، وروايته عن مجالد"( ) (1). وقد رجح الحافظ ابن حجر أن المناكير في روايته إنما هي ممن دونه، وأن

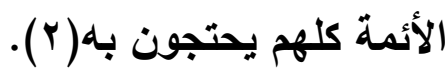
جـ - تثدده في معاوية بن صالح، وعدم قبول العلماء له:

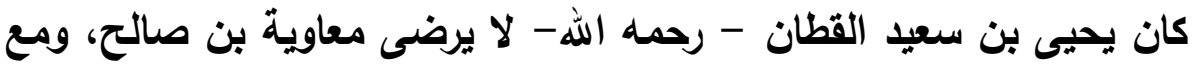

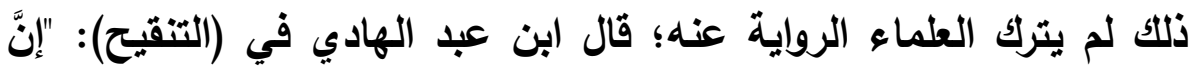

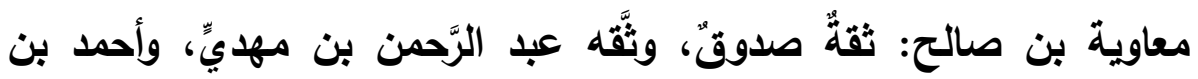

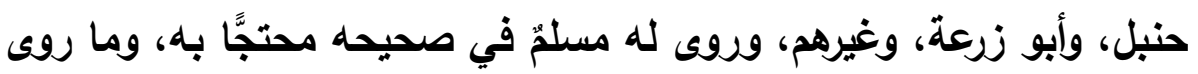

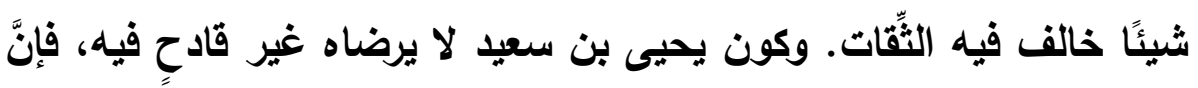

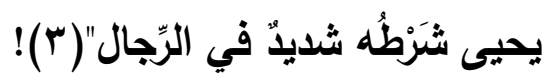

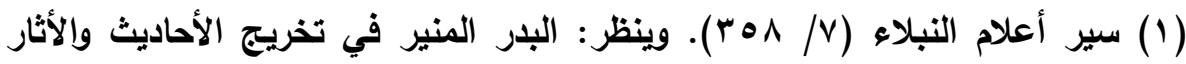

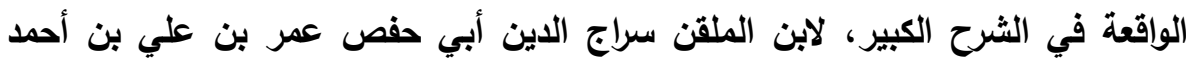

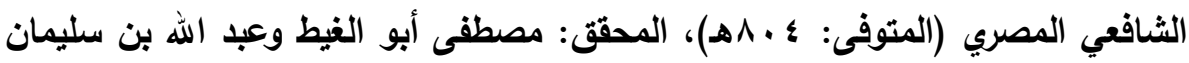

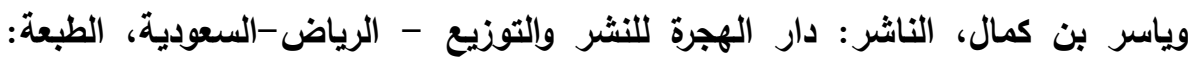

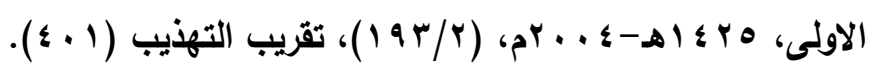

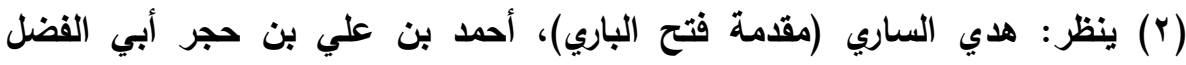

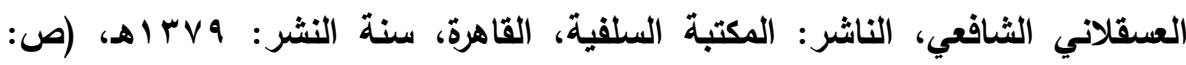
. ( 1 q .

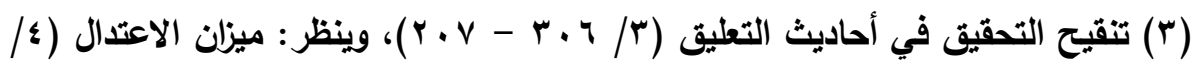

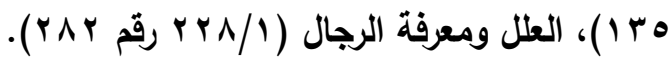


رده أحاديث عكرمة بن عمار مع رواية مسلم لها:

قال عبد الرحمن بن أبي حاتم: "نا صالح، نا علي قال: سألت يحيى عن

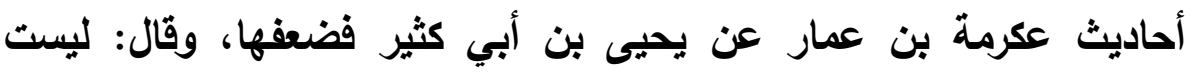

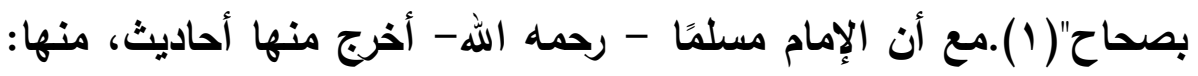

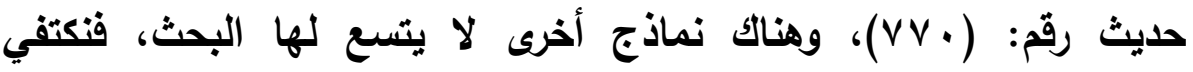

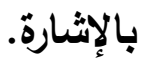

هـ - تثدده في عاصم بن سليمان الأحول؛ فقد قال: "لم يكن بالحافظ"(ץ). ولم يقبل أهل العلم منه ذلك بل وثقوه وممن وثقه سفيانُ الثوريُّ، وشعبة

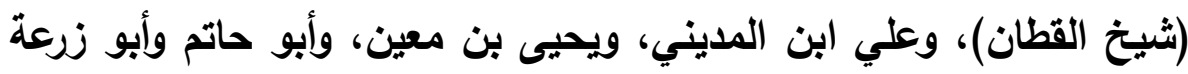

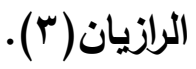

ومهما يكن من شيء؛ فالإمام يحيى بن سعيد القطان هو أحد أساطين علم

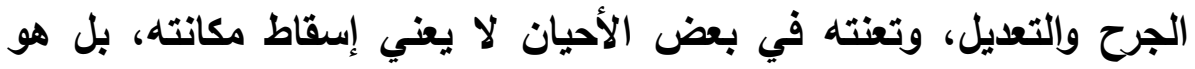
موصوف بجميل الأوصاف وأعلاها وأثرفها:

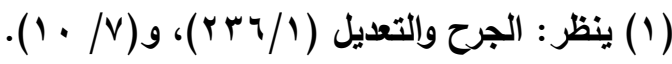

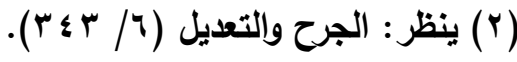

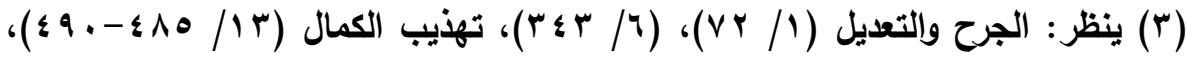

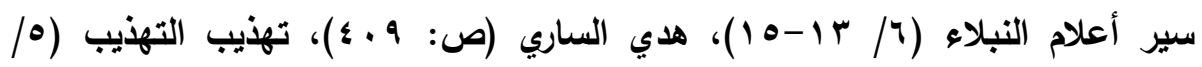

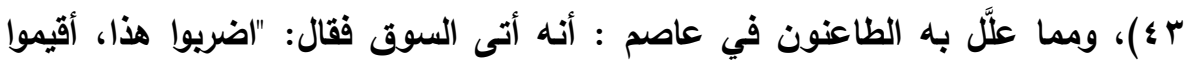
هذا.... وإنما فعل هذا؛ لأنه ولي الحسبة". 


\section{ه خامساً: ثناء العلماء على يميى القطان في باب الجرح والتعديل:}

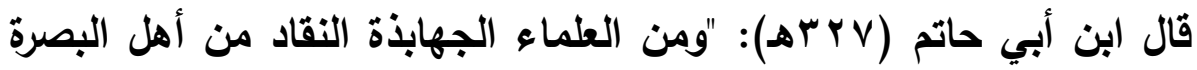

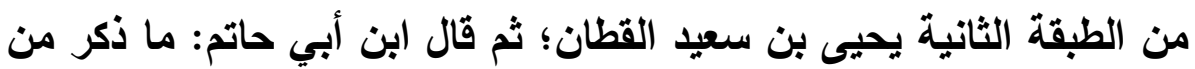
علم يحيى بن سعيد بناقلة الأخبار ومعرفته بأحوالهم ويصحة الآثار وسقيمها

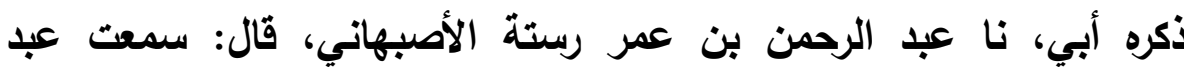
الرحمن بن مهدي، يقول: اختلفوا يوما عند شعبة، فقالوا: اجعل بينتا ويينك حكما، فقال: قد رضيت بالأحول يعني: يحيى بن سعيد القطان، فما برحنا حتى جاء يحيى فتحاكموا إليه، فقضى على شعبة، فقال له شعبة: ومن بله يطيق نقدك، أو من له مثل نقدك يا أحول، قال أبو محمد: هذه غاية المنزلة

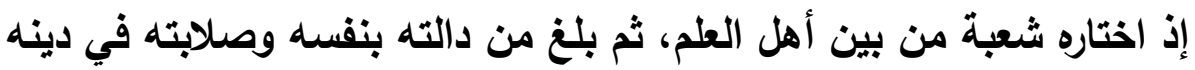
أن قضى على شعبة"، انتهى.

قال عبد الرحمن بن أبي حاتم: "أنا عبد الله بن أحمد بن حنبل فيما كتب إليَّ،

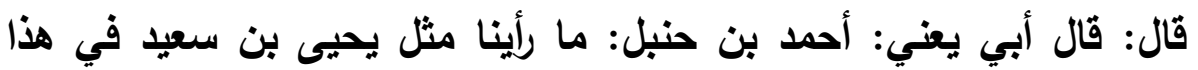
الثأن يعني: في معرفة الحديث ورواته، هو كان صاحب هذا الثأن... وما رأينا مثل يحيى، وجعل يرفع أمره جدًّا.

وقال -أيضًا -: حدثي أبي، قال: سئل أحمد بن حنبل عن يحيى بن سعيد، وعبد الرحمن بن مهاي، ووكيع، فقال: كان يحيى أبصرهم بالرجال وأنقاهم

حديثا، وأظنه قال: وأثثتهم"( ) (1).

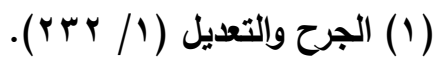




\section{" سادساً: مدى وجود آثار الشهصية الانطوانية في هياة يميى القطان}

\section{عموناً:}

قدّمنا أن معنى التعنت يدور حول الصلابة وترك اللين؛ فهو أخذ المري نفسه

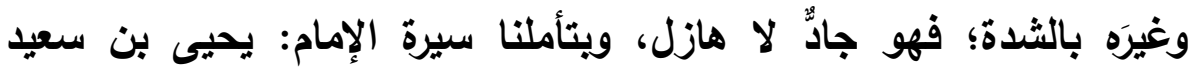

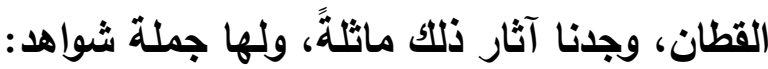

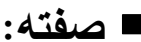

كان دؤويا صبورًا. ومن ذلك أنه لزم شعبة عشرين سنة (1)؛ قال أحمد بن محمد بن يحيى القطان: "لم يكن جدي يمزح، ولا يضحك إلا تبسمًا، ولا دخل

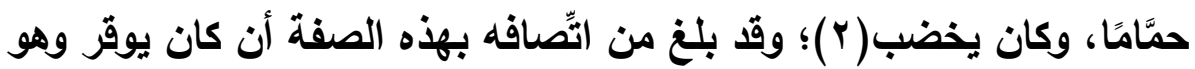

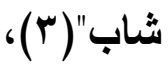
ه هيiٔته

قال الحافظ ابن عمار: "كنت إذا نظرت إلى يحيى القطان، ظنتت أنه لا يحسن شيئًا بزي التجار، فإذا تكلم، أنصت لله الفقهاء"( ع ).

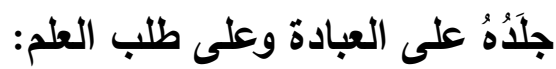

قال يحيى بن معين: "أقام يحيى بن سعيد عثرين سنة يختم القرآن كل

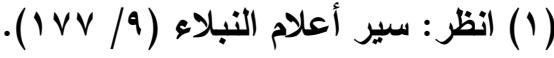

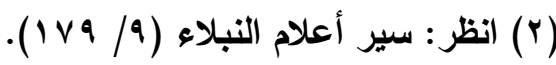

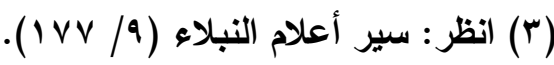

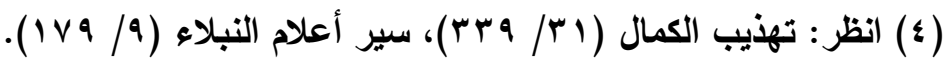




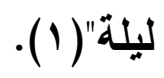

وقال -أيضًا-: "إن يحيى بن سعيد لم يفته الزوال في المسجد أريعين

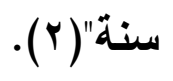

وقال عمرو بن علي: "كان يحيى بن سعيد القطان يختم القرآن كل يوم وليلة،

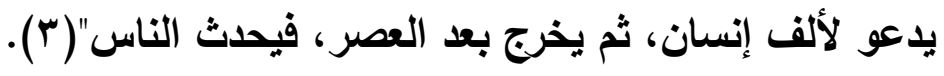
فأي جلَّ بعد هذا؟! وقال ابن خزيمة: "سمعت بُندارًا يقول: اختلفت إلى يحيى بن سعيد أكثر من

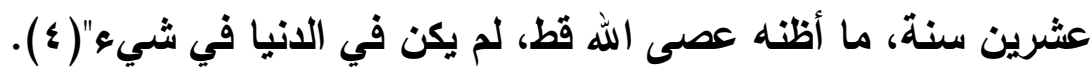
وفي بعض المصادر : قال: "اختلفت إليه عشرين سنة أو نحوها ما أظنه ذكر

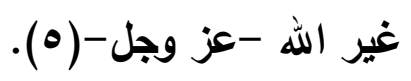
وكان إذا ذكر النار بكى، وإذا ذكر الجنة بكى، وإذا ذكر النبي إنه بكى، وإذا ذكر الموت أصابه ألم شديد( آ).

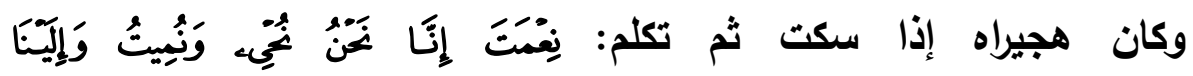

$$
\begin{aligned}
& \text { (1) انظر : سير أعلام النبلاء (1V9/9). }
\end{aligned}
$$

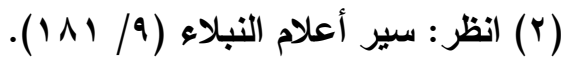

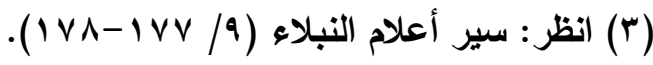

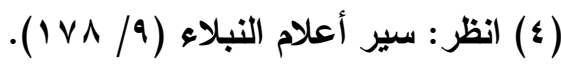

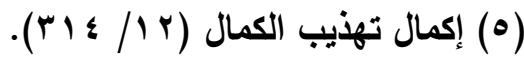

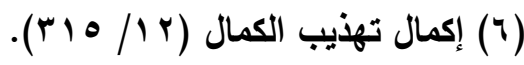




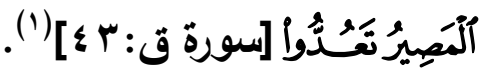

وكان طيلة يومه في الطلب؛ قال محمد بن يحيى بن سعيد: قال أبي: كنت أخرج من البيت، أطلب الحديث، فلا أرجع إلا بعد العتمة"(Y).

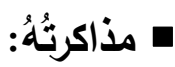

قال ابن مهدي: "لما قدم الثوري البصرة، قال: يا عبد الرحمن! جئني بإنسان أذ(كره.

فأتيته بيحيى بن سعيد، فذاكره، فلما خرج، قال: قلت للك: جئني بإنسان،

$$
\text { جئتني بشيطان -يعني: بهره حفظه-" (r). }
$$

وقال علي بن عبد الله المديني، قال: "سمعت يحيى بن سعيد، يقول: \ما ينبغي في الحديث غير خصلة ينبغي لصاحب الحديث أن يكون بيتا لأحد، ويكون يفهم ما يقال له، وينصر الرجال ثم يتعاهد ذاكه"( ) وَقَال أَبَو بَكْر الأثرم: "قال لي أَبَوُ عَبْد اللَّهِ (أحمد بن حنبل): رحم الله يَحْيَى

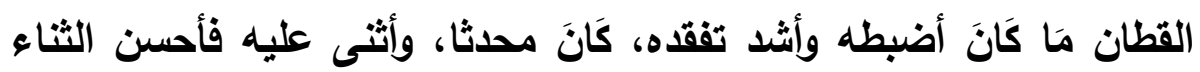
عليه".

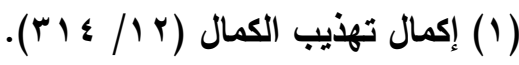

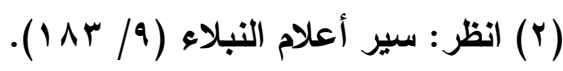

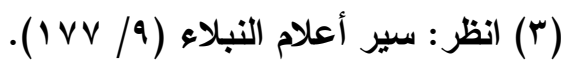

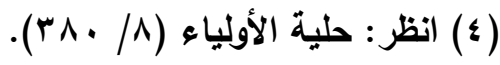




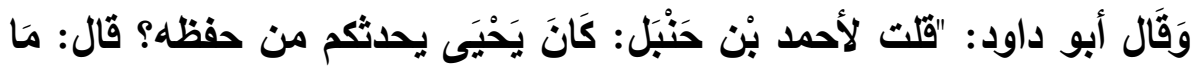

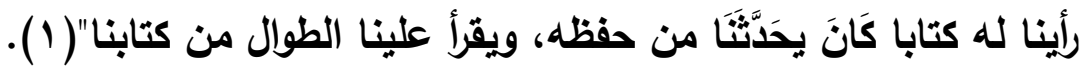

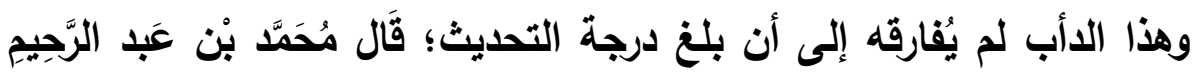
البزاز: "سمعت عليًا وذكر من طلب الحديث، فَقَّلَ: لم يكن من أصحابنا ممن لهن

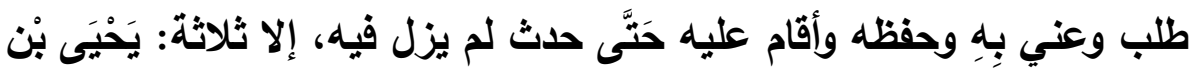

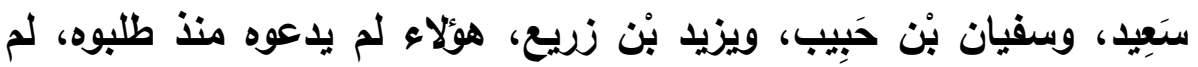

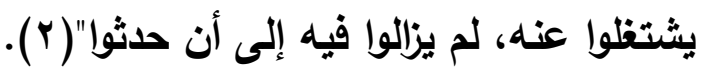
ومن صور الصلابة والجلد: الوقوف بين العصر والمغرب في مذاكرة العلم؛

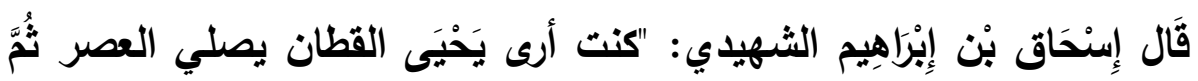

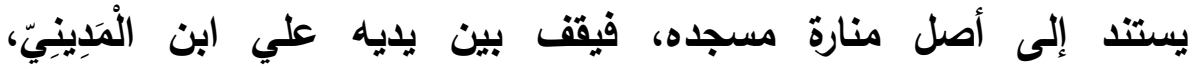

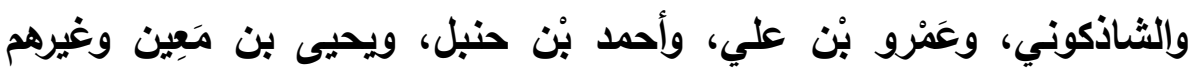

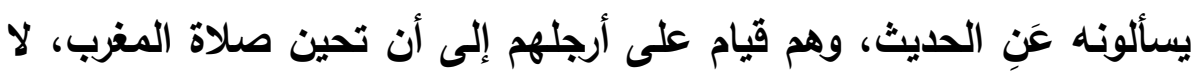
يَقُول لواحد منهم اجلس، ولا يجلسون هيبة له وإعظامًا"(؟).

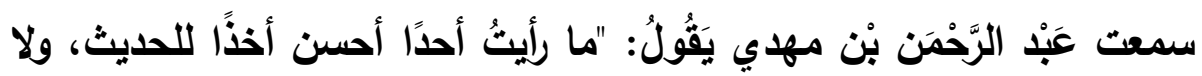

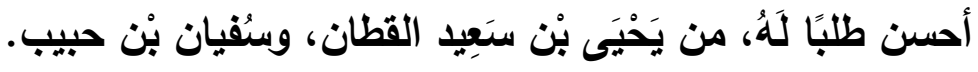
أَخْبَرًَا (بن الفضل، أخبرنا عبد الرّحمن بن جعفر، حَسَّتًَا يعقوب بْن سفيان،

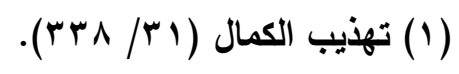

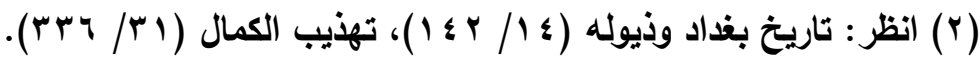

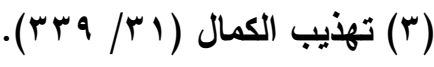


حَََّنَّي مُحَمَّد بْن عَبْد الرحيم قَالَ: سَمِعْتُ عليًا - وذَكر من طلب الحديث-

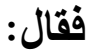

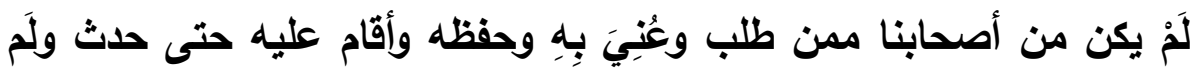

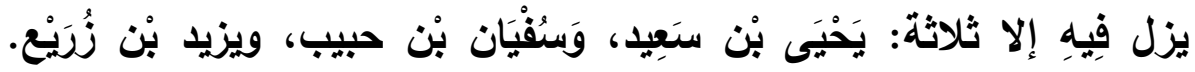

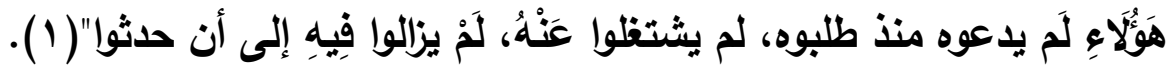

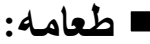

فلم يكن بذي انتقاء في المطعم، بل ما جاءه أكله؛ قال محمد بن أبي صفوان: "كان ليحيى القطان نفقة من غلته، إن دخل من غلته حنطة، أكل

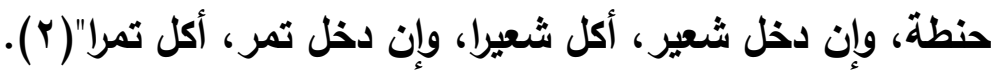
مقارنة أحواله العاديَّة بمنهجه في الرواية ونقد الرواة: من كان بهذه الصفة لا يعرِف سوى الجدّ، فالغالب أن نظرته إلى الناس

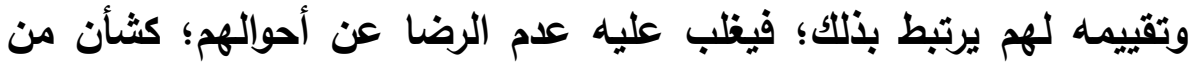

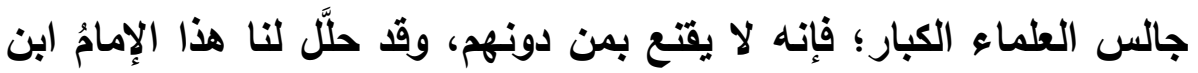

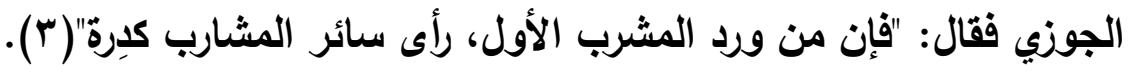

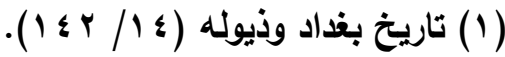

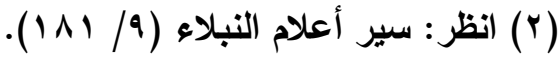

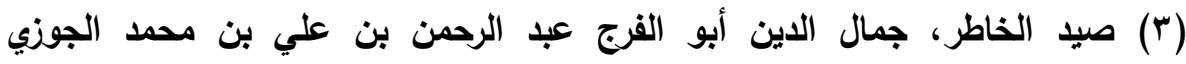

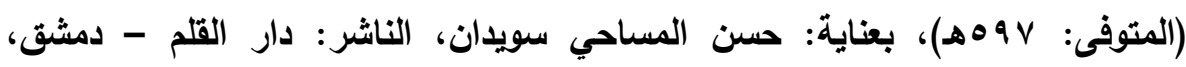

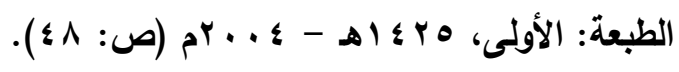


وقال: "ولو قلت: إني طالعت عشرين ألف مجلد، كان أكثر، وأنا بعد في الطلب! فاستفدت بالنظر فيها من ملاحظة سير القوم، وقدر همهم، وحفظهم

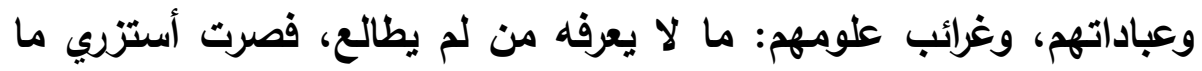
الناس فيه، وأحتقز همم الطلاب. ولله الحمد" ('). فبيِّنُ أن همته ومطالعته أحوال من سلف جعلته منتقصًا لعموم أهل زمانه،

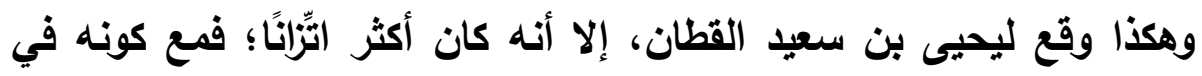

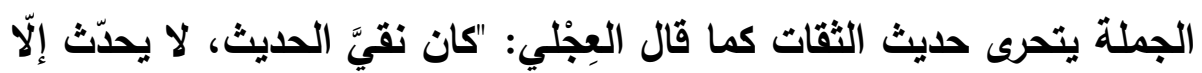

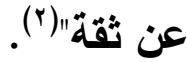

فقد قال صراحة: "لو لم أرو إلا عمن أرضى، لم أرو إلا عن خمسة"("). وقال: "كان معاذ ينهاني عن الرواية عن عمرو بن عبيد، وأنا لو تركت الرواية عن عمرو لتركتها عن نظرائه: ابن أبي نجيح وغيره"(\{). ومع دقته في الحفظ إلا أنه لم يُلْزمِ الناس بذلك؛؛ قال أبو قدامة السرخسي:

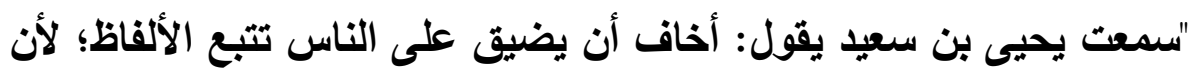

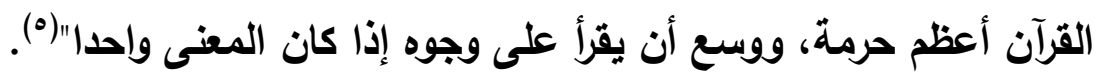

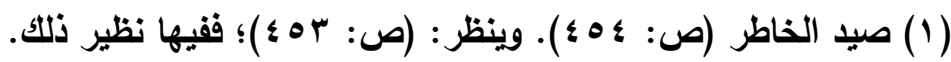

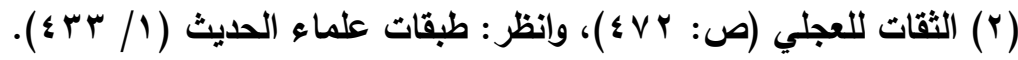

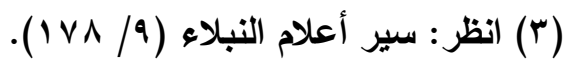

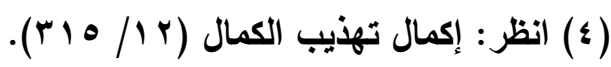

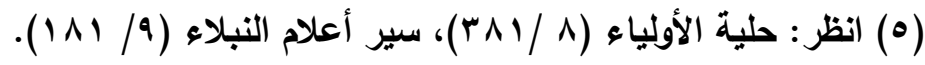




\section{ه سابعاً: قببه علماء الجرع والتعديل لعذه المفة في بحيس القطان:}

طالعنا نماذج من كلام أهل العلم فيمن جرحه يحيى، وكيف فطنوا إلى مراعاة صلابته وتعنته الشخصي، فلم يفتهم فهم معايير ميزان الرواة. ويهذا العرض السابق استطاع البحث عرض نماذج تطبيقية آثار أنماط الشخصية الخمسة على آراء المُحدِّثين من خلال عرض للمسائل الحديثية التي أثرت فيها هذه السمات .

\section{$\operatorname{sos} \diamond$}




\section{الفـاتمهاسة}

أهم النتانج والتوصيات

تناول هذا البحث أثر السمات الشخصية للمحدث على آرائه الحديثية، حيث عرض البحث السمات الثخصية التي حدَّدها علماء النفس، وضبطها أكثرُّهم في أنماط خمسة من خلال: مقدمة، وتمهيد، وستة مباحث؛ فعرض التمهيد التعريف اللغوي والاصطلاحي للسمات الثخصية باعتبار مفرديه، وياعتباره لقبًَا مركبًا، عند علماء النفس والمُحدِّثني؛؛ كما تعرض البحث لتقرير مداخل تطبيق هذه السمات الثخصية على المُحدثّثني، وبين وعورة المسلك من جهة أن عامة كتب التراجم إنما تحوي المواقف الدينية والمجالس التحديثية دون الحياة الثخصية والاجتماعية، وقد حاول البحث مجاوزة هذه العقبة، بمطالعة

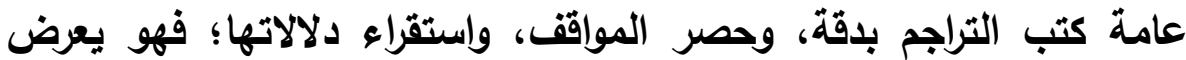
لعبادة المحدث، وكرمه أو بخله، ورحمته أو شدته؛ ليصل إلى سماته الثخصية، وهو مسلك مهم لاستكمال الأجزاء الناقصة في تراجم المُحدِّثني،

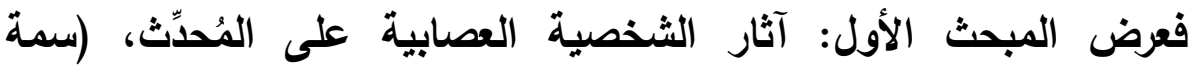
الغضب) أنموذجًا وتطبيق هذه الصفة على قتادة بن دعامة السدوسي،

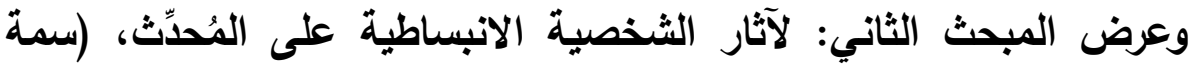

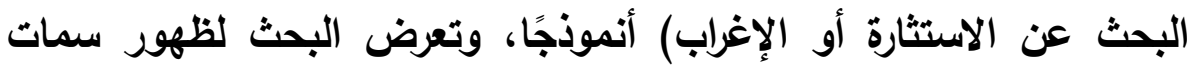

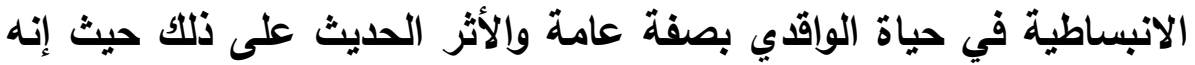

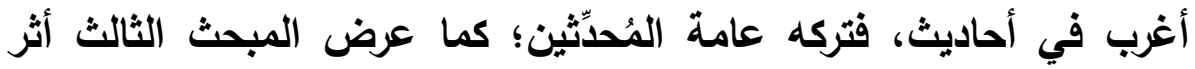
سمات الثخصية المقبولية على المُحدِّينين من خلال التعرض لاراسة هذه فئه 
الصفة في حياة عبد الله بن المبارك (سمة الرحمة والعطف)، وتعرض البحث لظهور هذه سمات الثخصية المقبولية في حياة عبد الله بن المبارك؛ وكان أثرها الحديثي أنه كان لا يترك حديث الرجل إلا إذا كان في عداد الساقطين،

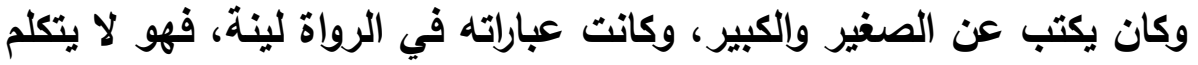

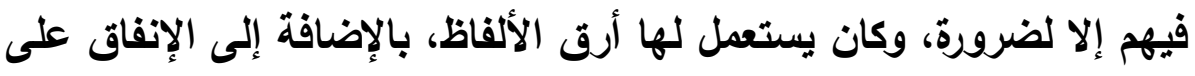

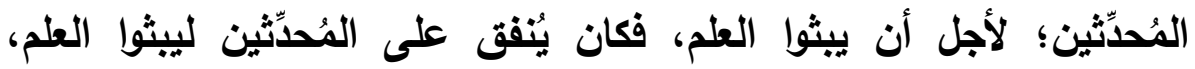
ويتوسع في التحديث رغبة في نفع الخلق، وكان واحدًا ممن تُحفظ السنة لانة

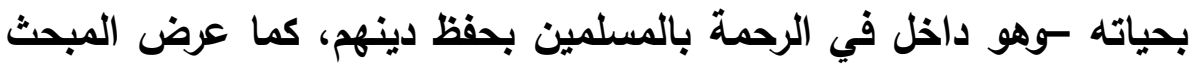

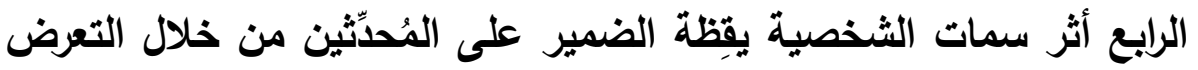
لاراسة هذه الصفة في حياة شعبة بن الحجاج (سمة البحث والتفتيش

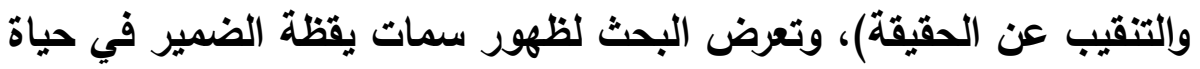

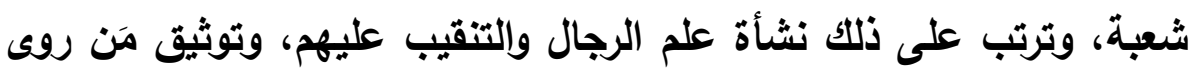

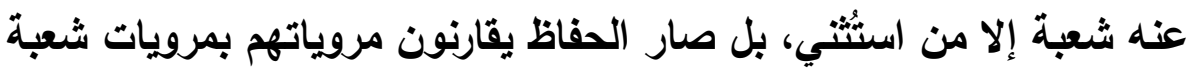

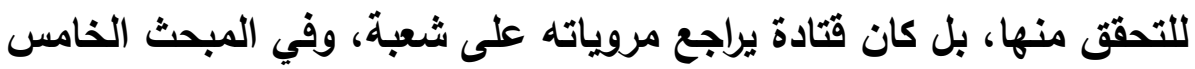

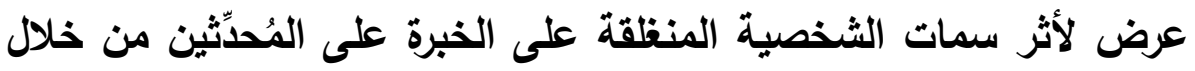
التعرض لاراسة هذه الصفة في حياة علي بن عاصم، وتعرض البحث لظهور

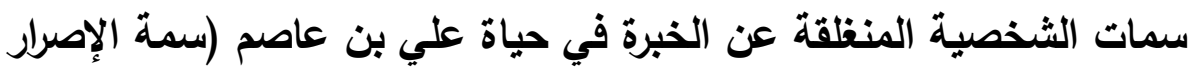

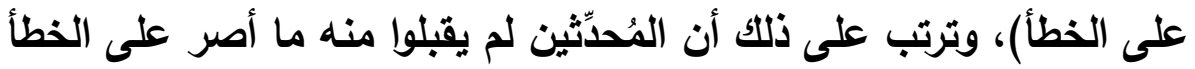

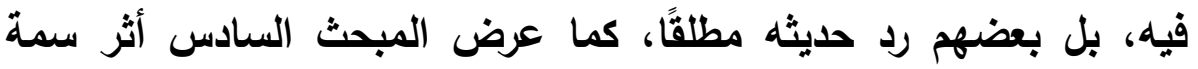
التعنت على الثُحدِّئن من خلال التعرض لدراسة هذه الصفة في حياة يحيى

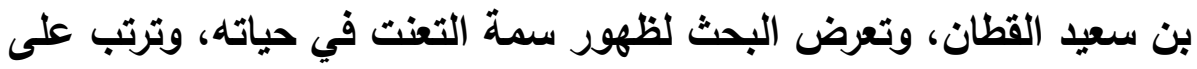


ذلك عدم قبول تجريحه لجماعة كمحم بن إسحاق، وعكرمة بن عمار، وتضعيفه أحاديث صحيحة، ولم يقبل المحدّثون منه ذلك.

\section{نتانه البمش : ومما سبق قتضه لابمث النتانه الآتية:}

- - تأثير السمات الثخصية للمحدث على آرائه الحديثية. - ـ وضوح السمات الشخصية المؤثرة على الآراء الحديثية للمحدث في حياته ولم تتفك هذه السمات عن مجمل تفاصيل حياته. - لم يفُ علماء الحديث عامة تلك التأثيرات، فوضعوا كلام كل واحدٍ ومروياته في ميزان عدل طبقًا لقواعد علمية موضوعية، وقد بقيت هذه القواعد ضابطة لعلم الحديث لا تكسرها السمات الشخصية؛ فسبحان من حفظ سنة نبيه بعباد استعملهم في نصرتها- والله أعلم - فئ - فات كتبَ التراجم كثرُ من التركيز على السمات الشخصية حيث كان مجمل تركيزها على المواقف الدينية والمجالس التحديثية دون الحياة الشخصية والاجتماعية التي لم تولها كثير التمام.

\section{توصيات البمث: ومن خلال ما سبق يوصي البمث بالآتي}

الاهتمام بالتذاخل المعرفي بين العلوم الثرعية بعضها البعض والعلوم الشرعية والعلوم الاجتماعية والنفسية والسياسية والاقتصادية من خلال طرح موضوعات بحثية أكاديمية في مرحلتي الماجستير والدكتوراه، وكذلك أبحاث الترقية

تبني مراكز بحثية للعلوم البينية ( علوم الثريعة بأنواعها مع العلوم الأخرى ) لإظهار أثر وتأثر العلوم الثرعية بمجمل العلوم الدنيوية لإظهار شمولية 
الإسلام من جهةٍ، بالإضافة إلى إضافة المعارف للعلماء والباحثين الإسلاميين.

إعادة صياغة وترتيب كتب التراجم وتواريخ الرجال بما يخرج ويوضح ويبرز المؤثرات على التخصص العلمي والآراء العلمية للعالم. طرح أفكار بحثية -ويكون لعل الله يوفق للكتابة البحثية فيها- تتعلق

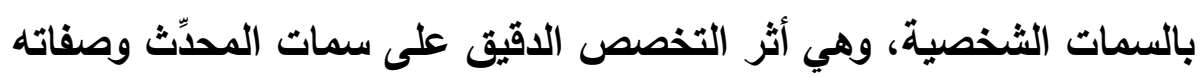
الخلقية وتأثير ذلك على آرائه العلمية.

$$
\text { وآخر دعوانا أن الحمد لله رب العالمين }
$$

وأُصلي وأسلمُ على سيدنا محمد وآس وآله وصحبه وسلم تسليمًا كثيرًا

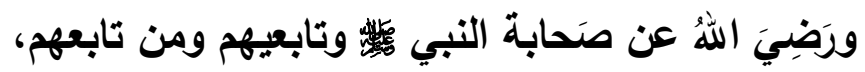

ومشايخنا وعلمائنا ومن لهم حُقوق علينا. 


\section{فهرس المصادر والمراجع}

1- "ابن حزم حياته وعصره-آراؤه وفقهه" - محمد أبو زهرة، - دار الفكر العربي، بدون رقم الطبعة، بدون تاريخ النشر.

r- الأبعاد الأساسية للشخصية، دكتور: أحمد محمد عبد الخالق، تقديم: دكتور: هانز أيزتك: أستاذ علم النفس بجامعة لندن - دار المعرفة الجامعية، الإسكندرية: (الطبعة الرابعة): (9 ( ) )، وأعيدت طباعته $\cdot($ ( 1994$)$

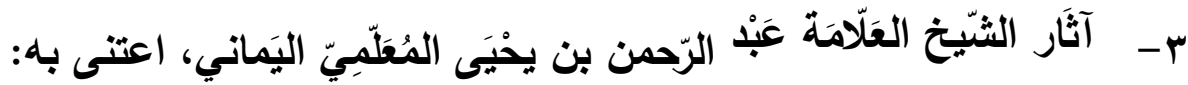
مجموعة من الباحثين منهم: المدير العلمي للمشروع علي بن مُحمَّد العِمْرَان وفق المنهج المعتمد: من الثيخ بكر بن عبد الله أبو زيد (رحمه الله تعالى)، الناشر: دار عالم الفوائد للنشر والتوزيع، الطبعة:

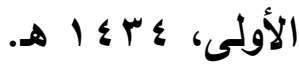

ع - إحياء علوم الدين، أبو حامد محمد بن محمد الغزالي الطوسي (المتوفى: ه • 0هـ)، الناشر: دار المعرفة - بيروت.

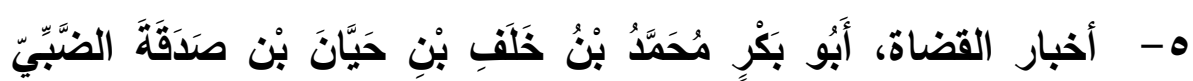

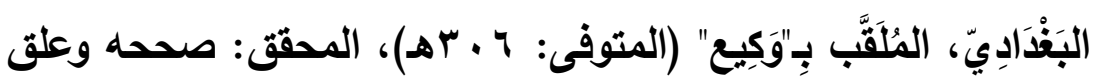
عليه وخرّج أحاديثه: عبد العزيز مصطقى المراغي، الناشر: المكتبة التجارية الكبرى، بشارع محمد علي بمصر لصاحبها: مصطقى محمد،

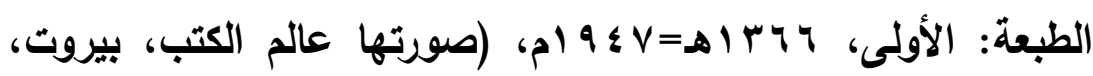




$$
\text { ومكتبة المدائن - الرياض). }
$$

צ- الأدب المفرد، محمد بن إسماعيل بن إبراهيم بن المغيرة البخاري، أبو

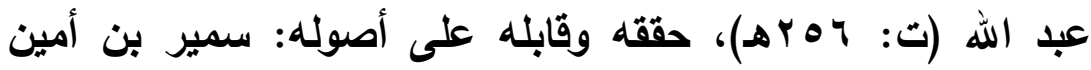
الزهيري، الناشر: مكتبة المعارف للنشر والتوزيع، الرياض، الطبعة:

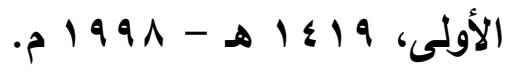

- V - الاستقامة، تقي الدين أبو العباس أحمد بن عبد الحليم بن عبد السلام بن عبد الله بن أبي القاسم بن محمد ابن تيمية الحراني الحنبلي

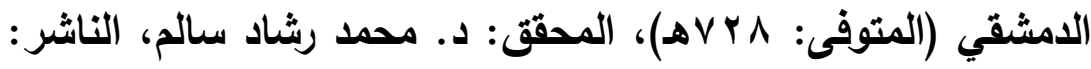
جامعة الإمام محمد بن سعود - المدينة المنورة، الطبعة: الأولى، $.1 \varepsilon \cdot r$

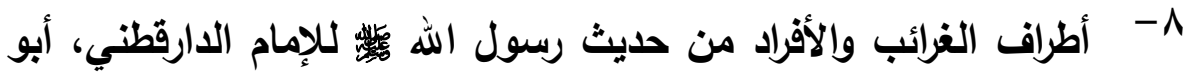
الفضل محمد بن طاهر بن علي بن أحمد المقسي الثيباني، المعروف بابن القيسراني (المتوفى: V V.0ه)، المحقى: محمود محمد محمود حسن نصار / السيد يوسف، الناشر: دار الكتب العلمية -

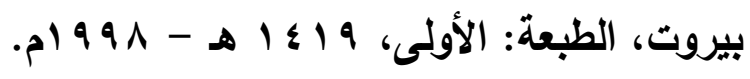

9- الاعتصام، إبراهيم بن موسى بن محمد اللخمي الغزناطي الشهير بالشاطبي (المتوفى: · V9ه)، تحقيق ودراسة: الجزء الأول: د. محمد بن عبد الرحمن الثقير، الجزء الثاني: د سعد بن عبد الله آل حميد، • 1 - إغاثة اللهفان في حكم طلاق الغضبان، محمد بن أبي بكر بن أيوب بن سعد شمس الدين ابن قيم الجوزية (المتوفى: اهـهـ)، المحقق:

$$
\text { r. . مجلة كلية اصول الاين والدعوة / العلد السابع و الثلاثتون } 9 \text { ـ ب م ـ الجزء الاول }
$$


محمد عفيفي، الناشر: المكتب الإسلامي، بيروت، لبنان، مكتبة فرق الخاني، الرياض، المملكة العربية السعودية الطبعة: الثانية، 1 • ـ أهـ، - $) 9 \wedge \wedge$

1 - إكمال تهذيب الكمال في أسماء الرجال، المؤلف: مغلطاي بن قليج بن عبد الله البكجري المصري الحكري الحنفي، أبو عبد الله، علاء الدين

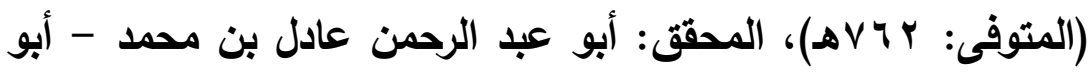

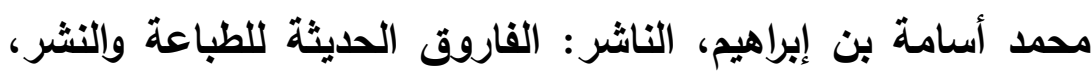

$$
\text { الطبعة: الأولىى، r Y I 1 هـ - I ... م م. }
$$

r ا الأمثال في الحديث النبوي، أبو محمد عبد الله بن محمد بن جعفر بن حيان الأنصاري المعروف بأبِي الثيخ الأصبهاني (المتوفى: 9 جبهـ)، المحقق: الاكتور عبد العلي عبد الحميد حامد، الناشر: الدار السلفية

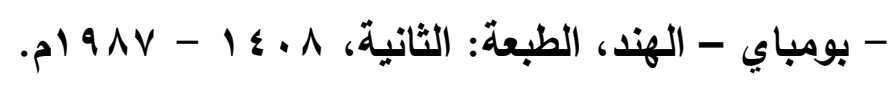

r ا - أنوار البروق في أنواء الفروق، أبو العباس شهاب الدين أحمد بن إدريس بن عبد الرحمن المالكي الشهير بالقرافي (ت: \& ع هـ)، الناشر : عالم الكتب. ع ا - البحر المحيط في أصول الفقه، أبو عبد الله بلر الاين محمد بن عبد الله بن بهادر الزركشي الشافعي (ت: ع \& وهـ)، الناشر: دار الكتبي،

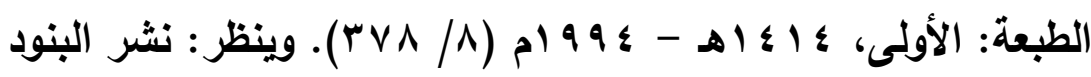
على مراقي السعود، عبد الله بن إبراهيم العلوي الشنقيطي، تقديم: الاي ولا سيدي بابا - أحمد رمزي، الناشر: مطبعة فضالة بالمغرب، 
بلدون طبعة، بلون تاريخ نشر.

ه - تاج العروس من جواهر القاموس، محمّد بن محمّد بن عبد الرزّلق

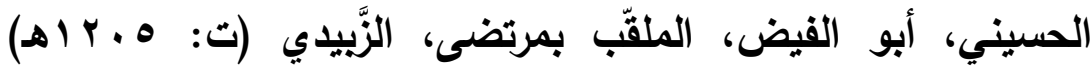
المحقق: مجموعة من المحققين، الناشر : دار الههاية.

17 - تاريخ ابن معين (رواية الدوري)، أبو زكريا يحيى بن معين بن عون بن زياد بن بسطام بن عبد الرحمن المري بالولاء، البغدادي (المتوفى: r r Pـ)، المحقق: د. أحمد محمد نور سيف، الناشر: مركز البحث العلمي وإحياء التراث الإسلامي - مكة المكرمة، الطبعة: الأولى،

$$
.19 \vee 9-1499
$$

IV

$$
\text { عبا الله (المتوفى: }
$$

1 ا - تاريخ بغداد، أبو بكر أحمد بن علي بن ثابت بن أحمد بن مهدي الخطيب البغدادي (المتوفى: باجـهـ)، المحقق: الدكتور بشار عواد معروف، الناشر: دار الغرب الإسلامي - بيروت، الطبعة: الأولى،

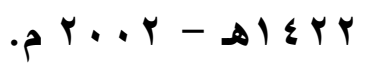

9 ا - تاريخ دمثق، أبو القاسم علي بن الحسن بن هبة الله المعروف بابن عساكر (المتوفى: الVهاته)، المحقق: عمرو بن غرامة العمروي،

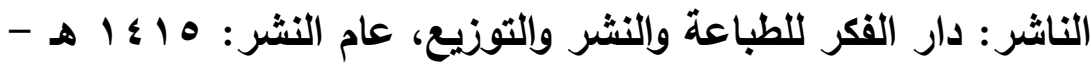

$$
\text { p) } 990
$$

• • - تحرير علوم الحديث، عبد الله بن يوسف الجديع، الناشر: مؤسسة 
الريان للطباعة والنشر والتوزيع، بيروت - لبنان، الطبعة: الأولى،

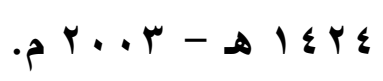

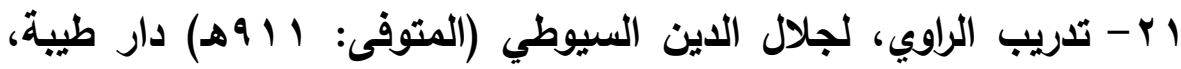

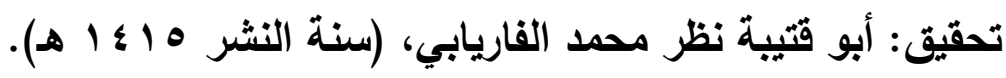

r r - التدين وعلاقته بالعوامل الخمسة الكبرى للشخصية لاى عينة من المراهقين الكويتيين، أحمد محمد عبد الخالق، وشيماء وليد الجوهري.

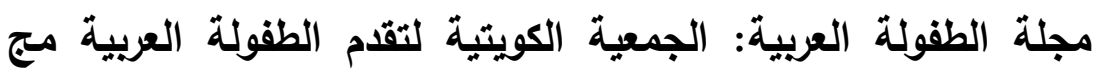

$$
\text { . }
$$

rr - ترتيب المدارك وتقريب المسالك، لأبي الفضل القاضي عياض بن

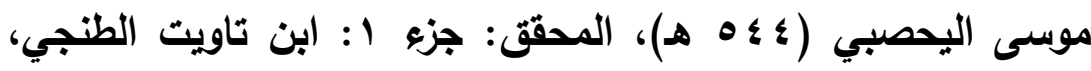

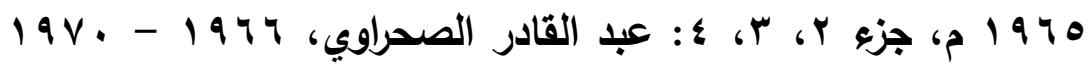

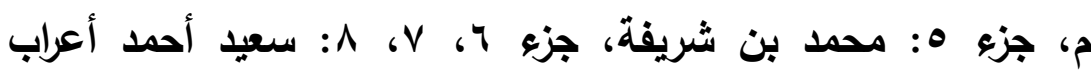

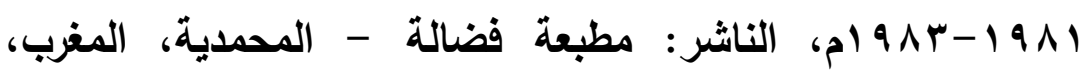
الطبعة: الأولى.

ع - تقدير الذات والعوامل الخمسة الكبرى للشخصية بوصفها منبئات للشفقة على الذات، فتون محمود خرنوب: دارسة ميدانية لاى على علينة

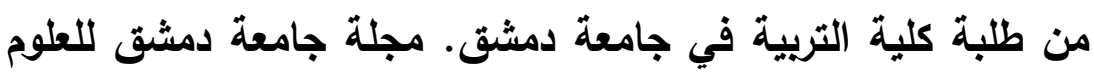

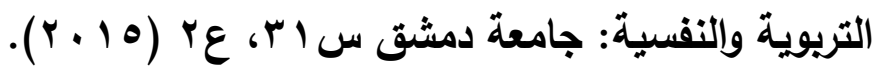

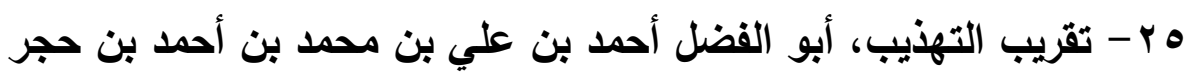

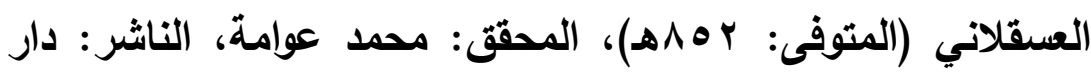

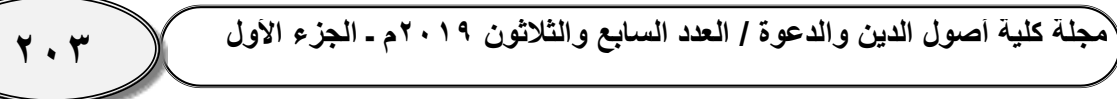




$$
\text { الرشيد - سوريا، الطبعة: الأولى، } 7 \text {. ع } 1919 \text { - } 19 \text {. }
$$

צr - التكوين الثقافي والاجتماعي لقضاة البصرة في العصر العباسي الثاني،

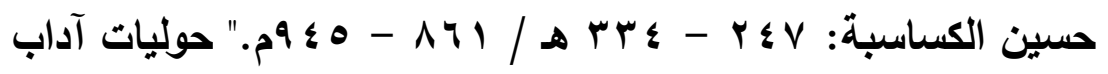
عين شمس: جامعة عين شمس - كلية الآداب مج بr (0. . ب): $.197-170$

- rV عبد الهادي الحنبلي (المتوفى: ؟ \& هـ)، تحقيق: سامي بن محمد بن جاد الله وعبد العزيز بن ناصر الخباني، الناشر: أضواء السلف -

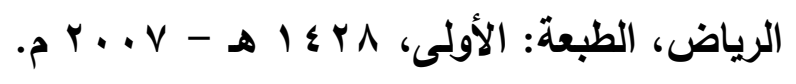

^r - تهذيب الأسماء واللغات، أبو زكريا محيي الاين يحيى بن شرف النووي (المتوفى: 7V Tه)، عنيث بنشره وتصحيحه والتعليق عليه ومقابلة أصوله: شركة العلماء بمساعدة إدارة الطباعة المنيرية، يطلب من: دار

$$
\text { الكتب العلمية، بيروت - لبنان. }
$$

q - تهذيب التهذيب أبو الفضل أحمد بن علي بن محمد بن أحمد بن حجر

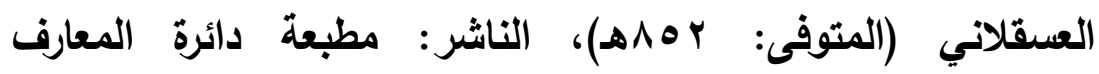

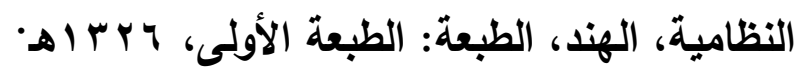

• ب- تهذيب الكمال في أسماء الرجال، المؤلف: يوسف بن عبد الرحمن بن يوسف، أبو الحجاج، جمال الاين ابن الزكي أبي محمد القضاعي الكلبي المزي (المتوفى: Y Y Vه)، المحقق: د. بشار عواد معروف،

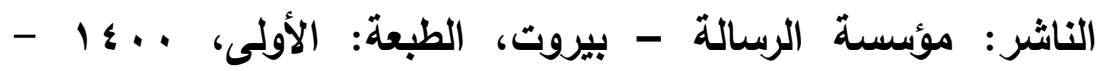




\section{.191.}

اب- تهذيب اللغة، محمد بن أحمد بن الأزهري الهروي، أبو منصور (ت:

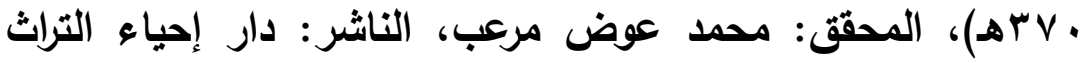

$$
\text { العربي - بيروت، الطبعة: الأولى، } 1 \text { ا. . r م. }
$$

r r - توجيه النظر إلى أصول الأثر، طاهر بن صالح (أو محمد صالح) ابن

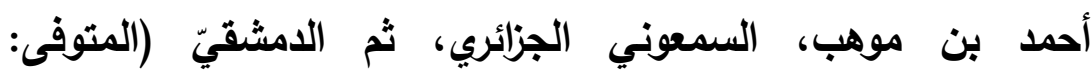
^ اسMه)، المحقق: عبد الفتاح أبو غدة، الناشر: مكتبة المطبوعات

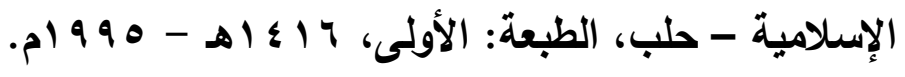

r T- الثقات، محمد بن حبان بن أحمد بن حبان بن معاذ بن مَعْبَا، التميمي، أبو حاتم، الدارمي، البُستي (المتوفى: ع ـهـه، طبع بإعانة: وزارة المعارف للحكومة العالية الهندية، تحت مراقبة: الاكتور محمد عبد المعيد خان مدير دائرة المعارف العثمانية، الناشر: دائرة المعارف

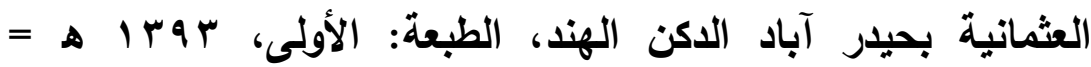

$$
.19 \vee r
$$

ع - الجامع المسند الصحيح المختصر من أمور رسول الله وأيامه = صحيح البخاري، محمد ابن إسماعيل أبو عبدالله البخاري الجعفي المحقق: محمد زهير بن ناصر الناصر الناشر: دار طوق النجاة (مصورة عن السلطانية بإضافة ترقيم محمد فؤاد عبد الباقي)

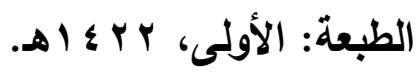

هـ - جامع بيان العلم وفضله، أبو عمر يوسف بن عبد الله بن محمد بن عبد البر بن عاصم النمري القرطبي (المتوفى: بآ هـ)، تحقيق: أبي

$$
\text { مجلة كلية اصول الدين والدعوة / العدد السابع والثلاثون } 9 \text { ـ ب م ـ الجزء الاول }
$$


الأثبال الزهيري، الناشر: دار ابن الجوزي، المملكة العربية السعودية،

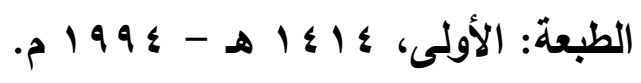

4س - الجرح والتعديل، أبو محمد عبد الرحمن بن محمد بن إدريس بن المنذر

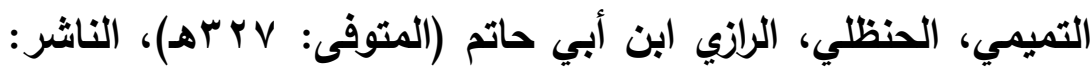

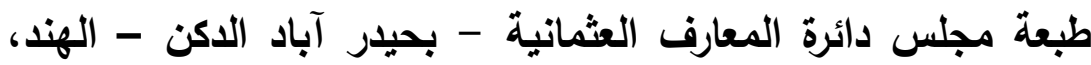

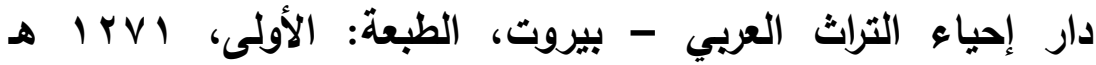
.p) 904 PV - الجزء الثالث: د هثام بن إسماعيل الصيني، الناشر: دار ابن الجوزي

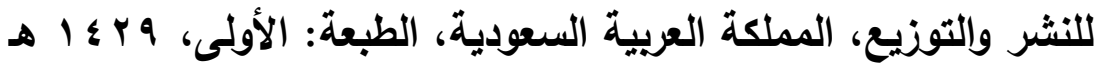

$$
\text { ... }
$$

^r - جزء من شرح تنقيح الفصول في علم الأصول، أبو العباس شهاب الدين أحمد بن إدريس بن عبد الرحمن المالكي الثهير بالقرافي

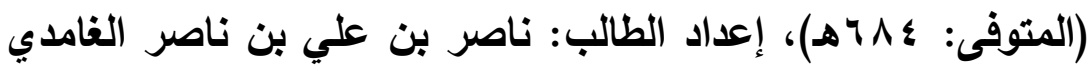

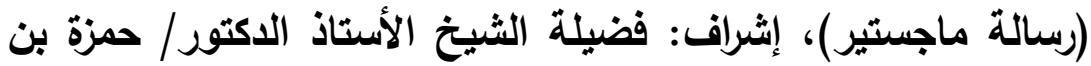

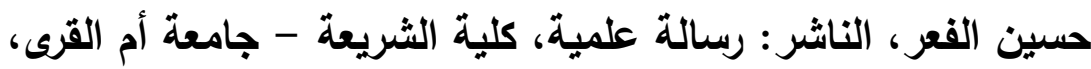

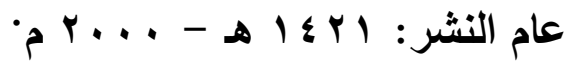

q ج- الجواهر والدرر في ترجمة شيخ الإسلام ابن حجر، المؤلف: شمس

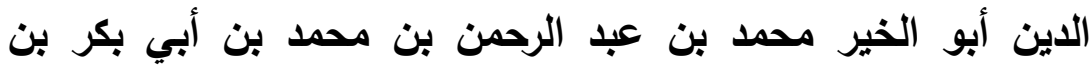

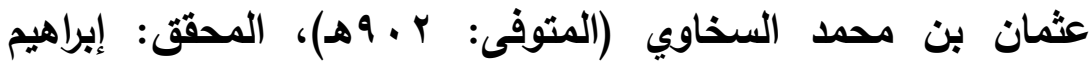

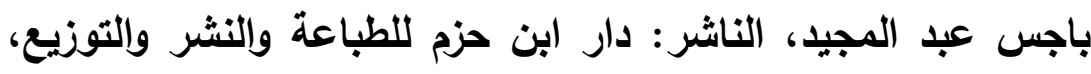


بيروت - لبنان، الطبعة: الأولى، 9 1 19 هـ - 1999 م.

• ع - الحاوي في الطب، أبو بكر، محمد بن زكريا الرازي (المتوفى: با بهـ)، المحقق: اعتىى به: هيثم خليفة طعيمي، الناشر: دار إحياء التراث

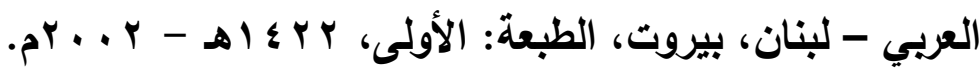

اء - حلية الأولياء وطبقات الأصفياء، المؤلف: أبو نعيم أحمد بن عبد الله بن أحمد بن إسحاق بن موسى بن مهران الأصبهاني (المتوفى:

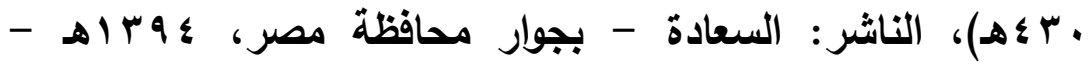
§ 9 ام، ثم صورتها عدة دور منها، دار الكتاب العربي - بيروت، دار الفكر للطباعة والنشر والتوزيع، بيروت، دار الكتب العلميةبيروت (طبعة 9 ، ع أه باون تحقيق). r ع - خاص الخاص، عبد الملك بن محمد بن إسماعيل أبو منصور الثعالبي (المتوفى: 9 ؟ \&ه)، المحقق: حسن الأمين، الناشر: دار مكتبة الحياة - بيروت/لبنان، بدون تاريخ نشر، ولا رقم طبعة. بـ - رسالة السجزي إلى أهل زيبي في الرد على من أنكر الحرف والصوث، عبيد الله بن سعيد بن حاتم السجزيّ الوائلي البكري، أبو نصر (المتوفى: ع § §ه)، المحقق: محمد با كريم با عبد الله، الناشر: عمادة البحث العلمي بالجامعة الإسلامية، المدينة المنورة، المملكة العربية السعودية، الطبعة: الثانية، بr ع هـ/ r . . rم. ؟ - - رؤوس المسائل 》المسائل الخلافية بين الحنفية والثافعيةه، جار الله أبو القاسم محمود بن عمر الزمخثري (YV ( 
وتحقيق: عبد الله نذير أحمد، أصل الكتاب: رسالة ماجستير للمحقق، قسم الدراسات العليا الشرعية فرع الفقه والأصول - كلية الثريعة والدراسات الإسلامية - جامعة أم القرى، مكة المكرمة، الناشر: دار البشائر الإسلامية للطباعة والنشر والتوزيع، بيروت - لبنان، الطبعة:

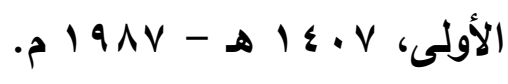

هـ - سمات الشخصية والاتِّجاه نحو السلطة والرفاق وعلاقتها بالسلوك العدواني لاى طلاب الجامعة، أسبابه ومظاهره والحُلول المقترحة لمعالجته، بحث مقدم إلى الأمانة العامة لاتحاد الجامعات العربية في

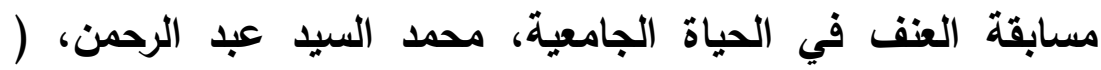

$$
\cdot(r \cdot .0
$$

צ - سمات أهل الحيث والسنة، محمد عبدالسلام العالم، المجلة العلمية لعلوم الثريعة: جامعة المرقب - كلية علوم الثريعة بالخمس عا

$$
.719-091:(r \cdot 11)
$$

\& V التفسير وعلوم القرآن والحديث وعلومه في كليات الشريعة والآداب في جامعتي دمثث وحلب، الناشر: مجلة مركز بحوث السئنَّة والسيرة -

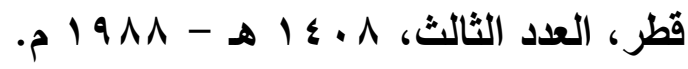
^ - سؤالات أبي داود للإمام أحمد بن حنبل في جرح الرواة وتعديلهم، أبو عبد الله أحمد بن محمد بن حنبل بن هلال بن أسد الشيباني (المتوفى: ا Y Yه)، المحقق: د. زياد محمد منصور، الناشر: مكتبة العلوم

$$
\text { مجلم كلية اصول الدين والدعوة / العدد السابع و الثلاثون } 9 \text { 1. بم ـ الجزء الاول }
$$


والحكم - المدينة المنورة، الطبعة: الأولى، ؛ 1 9 - سير أعلام النبلاء، شمس الدين أبو عبد الله محمد بن أحمد بن

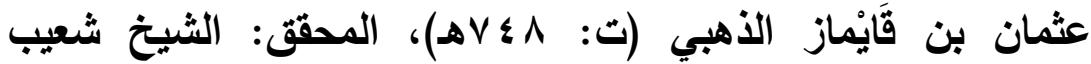

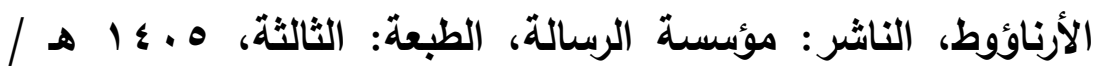
- $) 9 \wedge 0$

• - سير السلف الصالحين، إسماعيل بن محمد بن الفضل بن علي القرشي الطليحي التيمي الأصبهاني، أبو القاسم، الملقب بقوام السنة (المتوفى: هبهـ)، تحقيق: د. كرم بن حلمي بن فرحات بن أحمد، الناشر: دار الراية للنشر والتوزيع، الرياض، بدون تاريخ نشر، (ص:

$$
\cdot(1 \cdot \text {. Y }
$$

اهـ الشافعي حياته وعصره- آراؤه الفقهية، الإمام محمد أبو زهرة، ملتزم الطبع والنشر: دار الفكر العربي-القاهرة، الطبعة الثانية، 19 ـ ام. r - شرح ابن رشد لأرجوزة ابن سينا، (ص: ع r)، أبو الوليد محمد بن أحمد بن محمد بن أحمد بن رشد القرطبي الثهير بابن رشد الحفيد

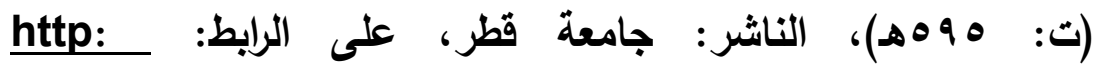
r 1/1/Vr.01//ar.lib.eshia.ir/ به - شرح الإلمام بأحاديث الأحكام، تقي الدين أبو الفتح محمد بن علي بن وهب بن مطيع القثيري، المعروف بابن دقيق العيد (المتوفى: r V هـ)، حققه وعلق عليه وخرج أحاديثه: محمد خلوف العبد الله، الناشر:

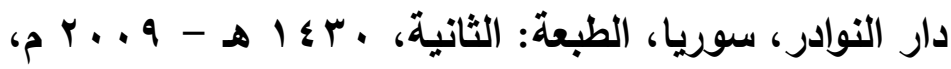


ـه- شرح علل الترمذي، زين الاين عبد الرحمن بن أحمد بن رجب بن الحسن، الستلامي، البغدادي، ثم الدمشقي، الحنبلي (المتوفى:

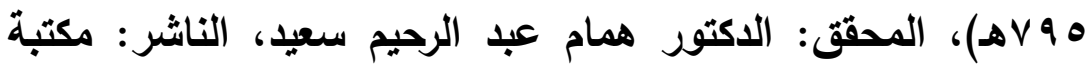

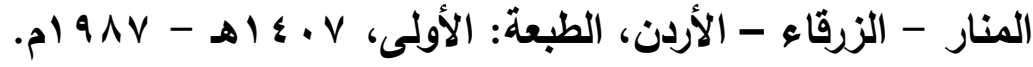
هـ - شرح نخبة الفكر في مصطلحات أهل الأثر، علي بن (سلطان) محمد، أبو الحسن نور الدين الملا الهروي القاري (المتوفى: ؛ 1 ـ اهـ)، المحقق: قام له: الثيخ عبد الفتاح أبو غدة، حققه وعلق عليه: محمد نزار تميم وهيثم نزار تميم، الناشر: دار الأرقم - لبنان / بيروت، رقم الطبعة: بلون، تاريخ النشر: بدون. צه - الثفقة بالذات وعلاقتها ببعض سمات الشخصية لاى عينة من طلاب جامعة الملك خالد، رياض نايل العاسمي، مجلة جامعة دمثث للعلوم

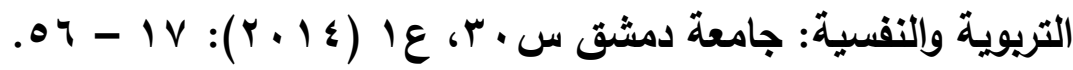
هV الجوزي (المتوفى: 9 Vهـ)، بعناية: حسن المساحي سويدان، الناشر:

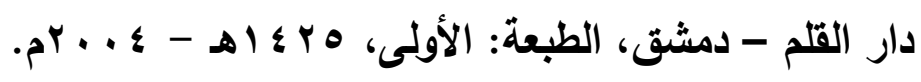

^ه - الضعفاء وأجوية أبي زرعة الرازي على سؤالات البرذعي، عبيد الله بن عبد الكريم بن يزيد الرازي أبو زرعة \& عهـ، المحقق: د. سعدي الهاشمي، الناشر: الجامعة الاسدلامية - المدينه المنورة، الطبعة:

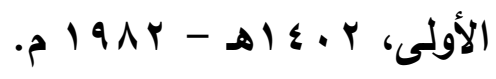

qه - الطبقات الكبير، محمد بن سعد بن منيع الزهري، المتوفى: • بr هـ،

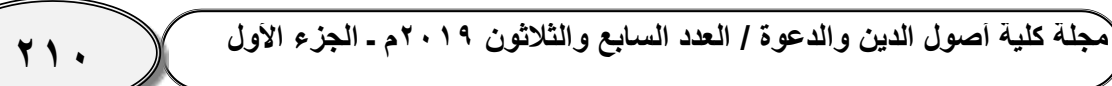


المحقق: علي محمد عمر، الناشر: مكتبة الخانجي - القاهرة، الطبعة:

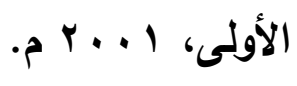

• - الضعفاء، أبو جعفر محمد بن عمرو بن موسى بن حماد العُقَيلي، المتوفى: r r هـ M. المحقق: قسم التحقيق بلار التأصيل، الناشر: دار

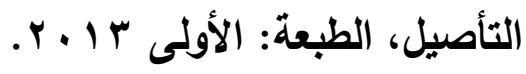

ا צ - العلل ومعرفة الرجال لأحمد رواية ابنه عبد الله، أبو عبد الله أحمد بن محمد بن حنبل بن هلال بن أسد الثيباني (المتوفى: إ؟به)، المحقق: وصي الله بن محمد عباس، الناشر: دار الخاني، الرياض،

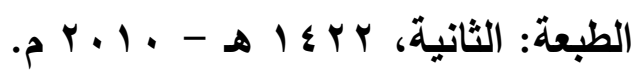

r צ - العلل، المؤلف: أبو محمد عبد الرحمن بن محمد بن إدريس بن المنذر

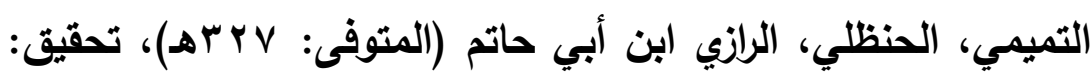
فريق من الباحثين بإشراف وعناية د// سعد بن عبد الله الحميد و د/ خالا بن عبد الرحمن الجريسي، الناشر: مطابع الحميضي، الطبعة:

$$
\text { الأولى، }
$$

با - العوامل الخمسة الكبرى في الشخصية لاى الموهوبين والعاديين، عبدالرحمن حطين الحارثي-وزارة التعليم المملكة العربية السعودية، عوني معين شاهين، جامعة الباجة-المملكة العربية السعودية، المجلة الدولية التريوية المتخصصة، المجلد (†). العدد (0)-حزيران V V . Y. צ - العوامل الخمسة الكبرى للشخصية وعلاقتها ببعض المتغيرات الايموغرافية لاى أسر المعاقين عقليًا-دراسة ميدانية على أسر 
التلاميذ المعاقين عقليًا بمعه المستقبل عطبرة- د. مجذوب أحمد مجمد أحمد قمر، جامعة دنقلا-كلية التربية- السودان، مجلة الدراسات والبحوث الاجتماعية-جامعة الشهيذ حمة لخضر -الوادي العدد: ب I

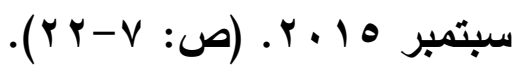

ه - - العوامل الخمسة للشخصية وعلاقتها بالاكتئاب لاى المرضى المترددين على مركز غزة المجتمعي - برنامج غزة للصحة النفسية، الطالب: نضال عبا اللطيف الثمالي، الجامعة الإسلامية- غزةة، عمادة الارسات العليا، كلية التربية-قسم علم النفس والإرشاد النفسي، إثراف الدكتور: نبيل كامل دخان، قدم هذا البحث استكمالاً لمتطلبات الحصول على درجة الماجستير في التريبة تخصص: الصحة النفسية

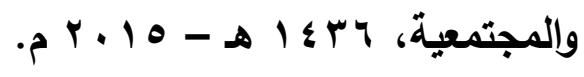

צ - العوامل الخمسة للشخصية: وجهه جياة لاراسة وقياس بنية الثخصية، د. هشام حبيب الحسيني محمد، أستاذ علم النفس التريوي المساعد، المركز القومي للامتحانات والتقويم التريوي، مكتبة الأنجلو المصرية.ة.

TV بن موسى بن عيسى، أبو الحسين البزاز البغدادي، دار السلف،

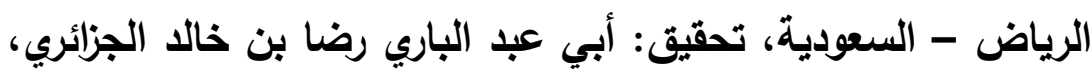

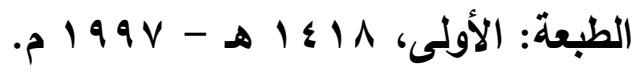

^ צ - قاموس الأمكنة التي يرد ذكرها في كتب الفتوح، علي بهجت، وكيل دار الآثار العربية، مطبعة التقدم، شارع محمد علي بمصر الطبعة الأولى: 


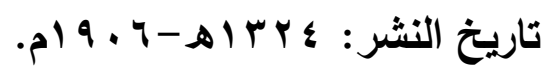

9 7 - القانون في الطب، الحسين بن عبد الله بن سينا، أبو علي، شرف

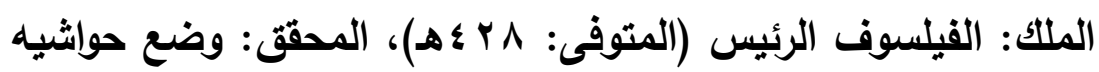
محمد أمين الضناوي، بدون بيانات نشر.

• 19^1 م)، تقديم: الاكتور محيي الدّين صنابر، ترجمة: الدكتور زكي تجيب محمُود وآخرين، الناشر: دار الجيل، بيروت - لبنان، المنظمة

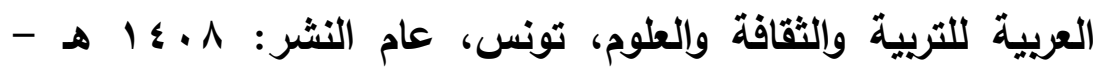

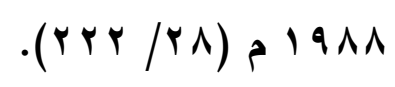

ا V - كتاب العين، المؤلف: أبو عبد الرحمن الخليل بن أحمد بن عمرو بن

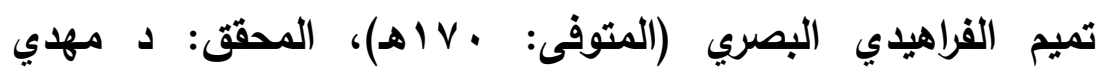
المخزومي، د إبراهيم السامرائي، الناشر : دار ومكتبة الهلال.

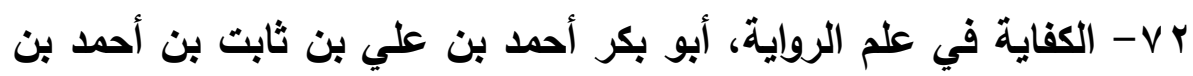

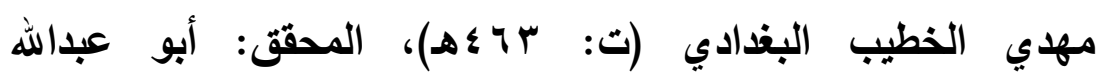
السورقي، إبراهيم حمدي المدني، الناشر: المكتبة العلمية - المدينة المنورة.

Tr - لسان العرب، محمد بن مكرم بن على، أبو الفضل، جمال الاين ابن منظور الأنصاري الرويفعى الإفريقى (ت: 1 VIه)، الناشر: دار صادر

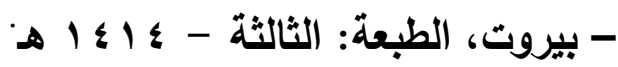
ع - لوائح الأنوار السنية ولواقح الأفكار السنية اشرح قصيدة ابن أبي داود 
الحائية في عقيدة أهل الآثار السلفيةه، محمد بن أحمد بن سالم

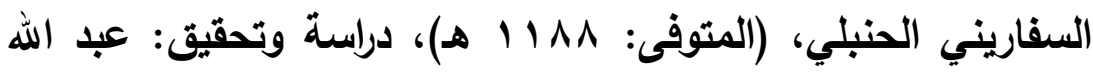

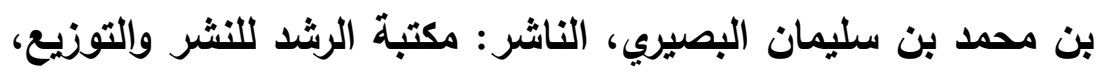

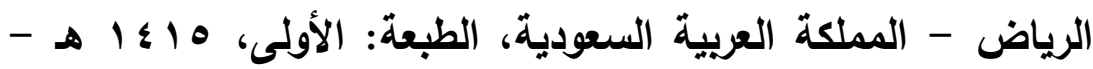
. 1995

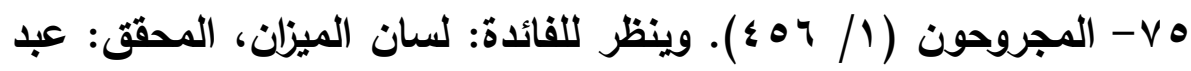

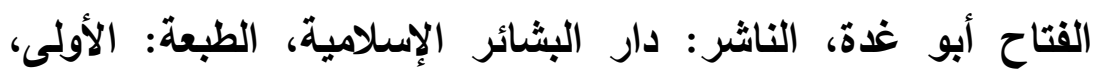
. $r$ r..r



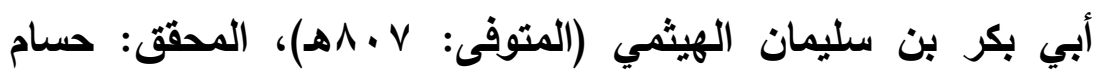

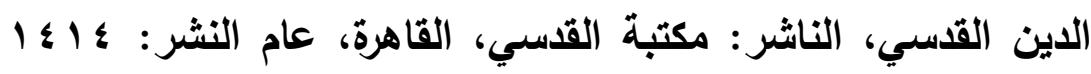

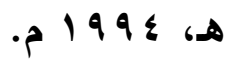

-VV المحدث الفاصل بين الزاوي والواعي، المؤلف: أبو محمد الحسن بن

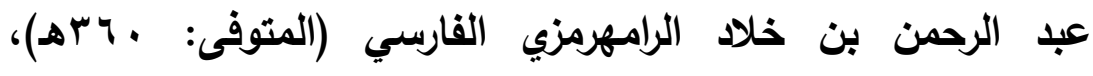

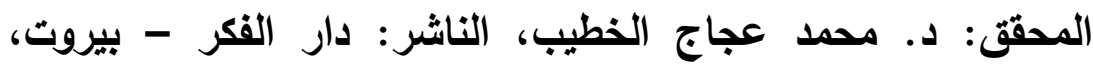
الطبعة: الثالثة، ؛ ـ ـ ا.

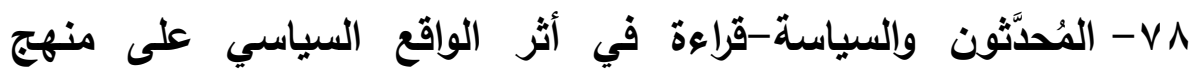

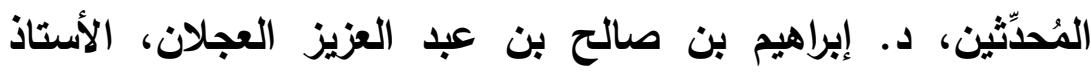

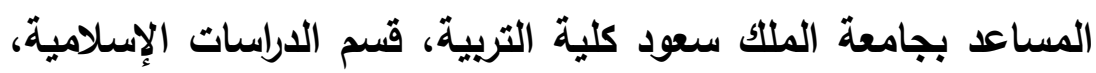

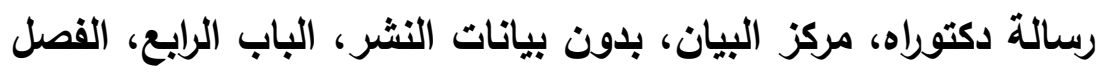


الأول: المبحث الثاني: دراسة الرواة الثقات الذين طُعِن فيهم بالتهمة السباسبة.

- V 9 بن أيوب بن سعد شمس الدين ابن قيم الجوزية (المتوفى: 1 (الهمه)،

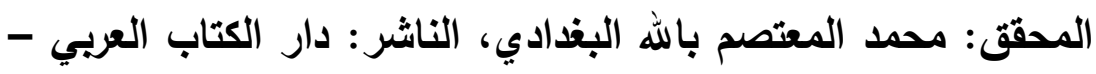

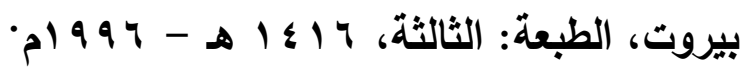
• - المدخل إلى البحث في العلوم السلوكية، صالح حمد العساف، الناشر:

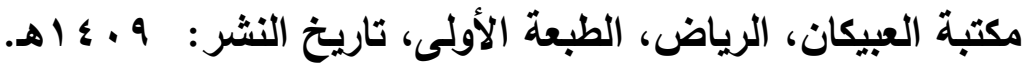
ا 1- المستدرك على الصحيحين، أبو عبد الله الحاكم محمد بن عبد الله بن

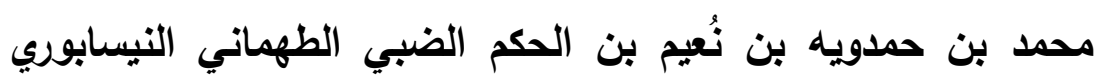

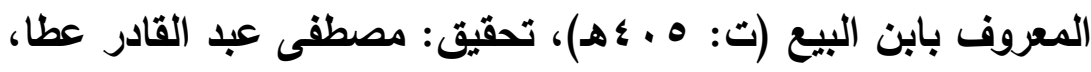

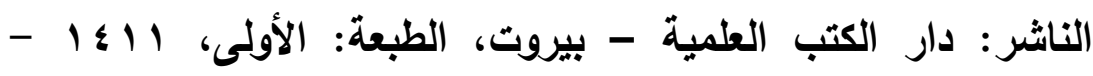
.199.

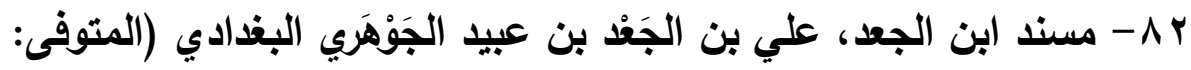

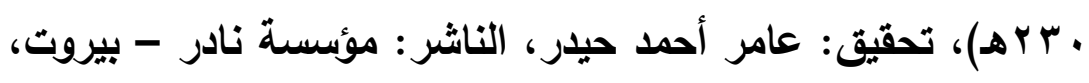

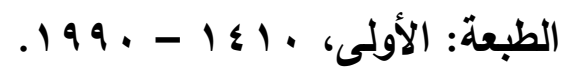

rی - مسند أحمد، أبو عبد الله أحمد بن محمد بن حنبل بن هلال بن أسد

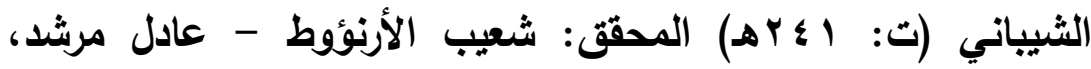

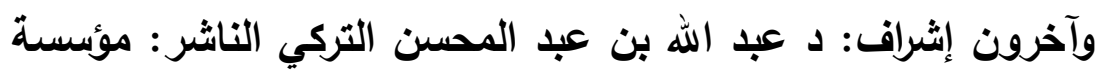

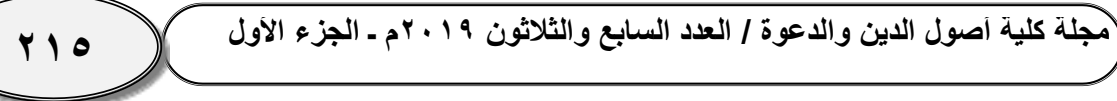




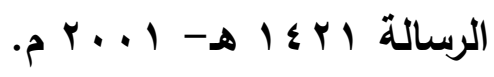

§^- المسند الصحيح المختصر بنقل العدل عن العدل إلى رسول الله المسمى صحيح مسلم، مسلم ابن الحجاج أبو الحسن القشيري

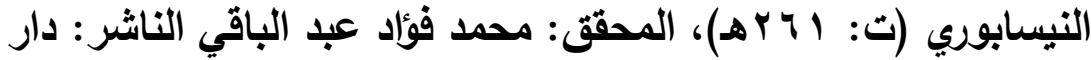

$$
\text { إحياء التراث العريي - بيروت. }
$$

ه - مصادر السيرة النبوية ومقدمة في تدوين السيرة، المؤلف: محمد يسري سلامة، تقديم: د. بشار عواد معروف الناشر: دار الجبرتي - دار

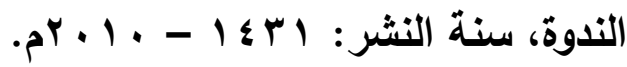

\1 - المصباح المنير، لأحمد بن محمد بن علي الفيومي المقري (المتوفى نحو · VV هـ)، دراسة وتحقيق: يوسف الثيخ محمد، الناشر : المكتبة

العصريـة.

- مV (المتوفى: \& \& \& اهـ) بمساعدة فريق عمل، الناشر: عالم الكتب،

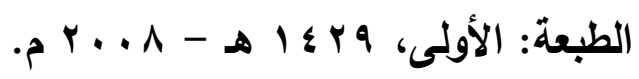

^^1 - المعجم الوسيط، مجمع اللغة العربية بالقاهرة (إبراهيم مصطقى / أحمد الزيات / حامد عبد القادر / محمد النجار)، المعجم الوسيط، دار

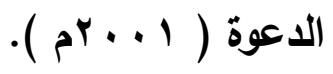

9 - مقالات الإسدلاميين واختلاف المصلين، علي بن إسماعيل الأثنعي أبو الحسن، الناشر : دار إحياء التراث العربي - بيروت، الطبعة الثالثة،

تحقيق : هلموت ريثر. 
• 9- مقاييس اللغة، لابن فارس (ت هوبه)، المحقق: عبد السلام محمد

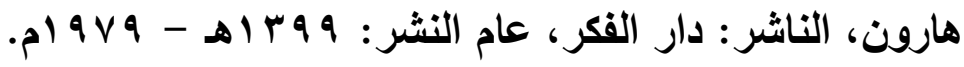

ا 9 - مقدمة ابن خلاون، عبد الرحمن بن محمد بن محمد، ابن خلاون أبو زيلد، ولي الاين الحضرمي الإشبيلي (المتوفى: ^ • ^هـ)، بلون بيانات نشر

r - مناهج البحث العلمي، عبد الرحمن بلوي، الناشر: وكالة المطبوعات بالكويت، الطبعة الثالثة، تاريخ النشر: 9VV أم.

بو - منهاج السنة النبوية، تقي الدين أبو العباس أحمد بن عبد الحليم بن عبد السلام بن عبد الله بن أبي القاسم بن محمد ابن تيمية الحراني

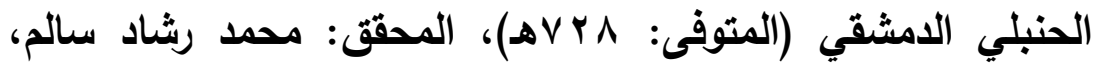
الناشر: جامعة الإمام محمد بن سعود الإسلامية، الطبعة: الأولى،

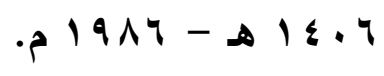

צ - الموافقات، إبراهيم بن موسى بن محمد اللخمي الغرناطي الشهير بالشاطبي (·و هـ)، المحقق: أبو عبيدة مشهور بن حسن آل

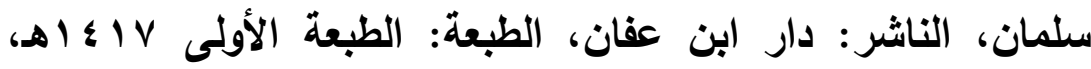

$$
\text { - } 199 \mathrm{~V}
$$

ه - نظرية الأنماط Types Theory من: علاقة بعض سمات الشخصية بانحراف الأحداث في مدينة الرياض، سعيد رفعان العجمي، دراسة لاستكمال متطلبات الحصول على الماجستير في العلوم الاجتماعية، إشراف: عبدالحفيظ بن سعيد مقدم، جامعة نايف العربية للعلوم 


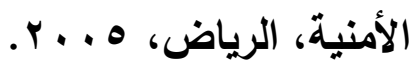

צ - - الواقدي وكتابه المغازي منهجه ومصادره، الدكتور عبد العزيز بن سليمان بن ناصر السلومي، رسالة دكتوراه مقدمة إلى الجامعة الإسلامية بالمدينة المنورة، الناشر : مكتبة الملك فهر الوطتية، الطبعة

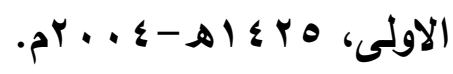

9V و وفيات الأعيان وأنباء أبناء الزمان، المؤلف: أبو العباس شمس الدين أحمد بن محمد بن إبراهيم بن أبي بكر ابن خلكان البرمكي الإربلي

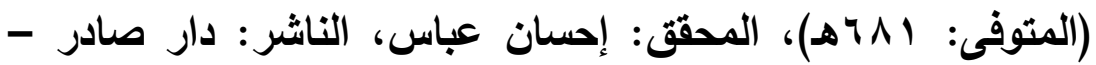

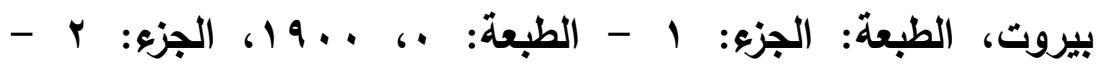

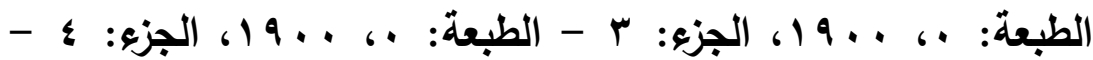

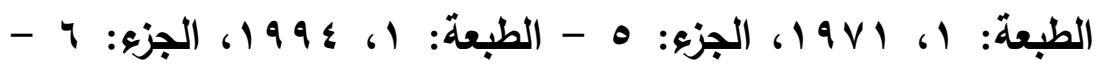

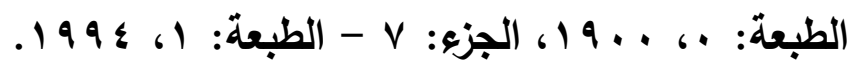

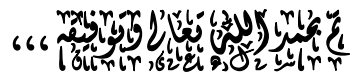

